University of Louisville

ThinkIR: The University of Louisville's Institutional Repository

Electronic Theses and Dissertations

$8-2020$

\title{
Compassion or neoliberal governance: critiquing the discourse of compassionate Louisville.
}

Ekramul Islam

University of Louisville

Follow this and additional works at: https://ir.library.louisville.edu/etd

Part of the Urban Studies and Planning Commons

\section{Recommended Citation}

Islam, Ekramul, "Compassion or neoliberal governance: critiquing the discourse of compassionate Louisville." (2020). Electronic Theses and Dissertations. Paper 3523.

https://doi.org/10.18297/etd/3523

This Doctoral Dissertation is brought to you for free and open access by ThinkIR: The University of Louisville's Institutional Repository. It has been accepted for inclusion in Electronic Theses and Dissertations by an authorized administrator of ThinkIR: The University of Louisville's Institutional Repository. This title appears here courtesy of the author, who has retained all other copyrights. For more information, please contact thinkir@louisville.edu. 


\title{
COMPASSION OR NEOLIBERAL GOVERNANCE: CRITIQUING THE
} DISCOURSE OF COMPASSIONATE LOUISVILLE

\author{
By \\ Ekramul Islam \\ BBA, North South University, 2010 \\ MS, North South University, 2014 \\ MBA, IBA, Dhaka University, 2016 \\ A Dissertation \\ Submitted to the Faculty of the \\ College of Arts and Sciences of theUniversity of Louisville \\ in Partial Fulfillment of the Requirements \\ for the Degree of \\ Doctor of Philosophy \\ in Urban and Public Affairs \\ Department of Urban and Public Affairs \\ University of Louisville Louisville, Kentucky
}

August 2020 

COMPASSION OR NEOLIBERAL GOVERNANCE: CRITIQUING THE DISCOURSE OF COMPASSIONATE LOUISVILLE

By

Ekramul Islam

BBA, North South University, 2010

MS, North South University, 2014

MBA, IBA, Dhaka University, 2016

A Dissertation Approved on

August 7, 2020

by the following Dissertation Committee:

Dr. Margath Walker, Dissertation Director

Dr. David Imbroscio

Dr. Daniel DeCaro

Dr. Derek Ruez

Dr. John-Robert Curtin 


\section{ACKNOWLEDGMENTS}

First, I want to thank my professor and dissertation chair, Dr. Margath Walker. She has been extremely kind and patient with me through the dissertation process. She has guided me in each and every step and has always been there for me. She is not only a great mentor but also a wonderful human being. I am indebted to her for this and cannot be thankful enough. I would also like to thank the other members of the Committee, Dr. David Imbroscio, Dr. Daniel DeCaro, Dr. Derek Ruez, and Dr. John-Robert Curtin for their comments and assistance over the past two years.

I want to dedicate this to my family: my mother Shaheena Islam, father Mohammad Noor Islam, brother Mohammad Ibrahim Hasan, and Lutfar Rahman. I come from a humble background from Bangladesh. I will be the first Doctorate in the family (and in the village). I am thankful to each of the family members for all the encouragement to get through this. Writing this dissertation during the COVID-19 pandemic has not been easy. Apart from the operational challenges of conducting the research, the COVID-19 pandemic also brought tremendous stress and loss. My close family members were infected and one of my uncles passed away due to the infection. The social lockdown has also induced terrible mental anxiety. I am grateful to all friends, wellwishers, and peers who helped me go through this. I love you all. 


\title{
ABSTRACT \\ COMPASSION OR NEOLIBERAL GOVERNANCE: CRITIQUING THE DISCOURSE OF COMPASSIONATE LOUISVILLE
}

\author{
Ekramul Islam
}

August 7th, 2020

Since 2011, the city of Louisville, the site of this research, has been calling itself "Compassionate City." The dissertation takes Compassionate Louisville as a city brand and seeks to investigate the effect of the image construction on the local politics. It aims to investigate the latent discourses produced by Compassionate Louisville in relation to the neoliberal political economy of the city. This dissertation employs the Critical Discourse Analysis (CDA) methodology. Compassionate Louisville, being a brand, produces a discourse of compassion. The CDA methodological approach helps to investigate this manufactured discourse in relation to the neoliberal socio-political context of the city. To conduct the study, the dissertation has analyzed textual data from a variety of sources, including interviews of key participants, city government reports, planning documents, meeting minutes of Metro Council, local news publications, websites of the city government, and relevant non-profit organizations. There are three specific but interrelated findings of this dissertation. First, the discourse produced by Compassionate Louisville permeates the political narrative of Louisville and is increasingly used in policy rationales, contestation, debates, and claim-making. The discourse is strategically used by various groups, including politicians, city officials, religious organizations, activists, non-profits, and businesses. Second, the discourse of compassion aids neoliberalism 
by privatizing the responsibility of welfare in the disguise of a moral high ground of compassion. In the process, it depoliticizes social problems, displaces rights, and entrenches the precarity of the communities. Third, the discourse of compassion is an urban version of humanitarian governance and acts as a technology of neoliberalism. It serves to manage the marginalized population of the city, discipline emotions to make the working population more compliant, and create the ground to transform emotions into a productive asset through which value can be extracted. Taken together, the dissertation finds that the discourse of compassion in Louisville originates and operates in the social context of neoliberalism- it works the work of capital in the disguise of a humanitarian narrative. 


\section{TABLE OF CONTENTS}

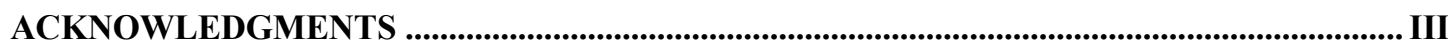

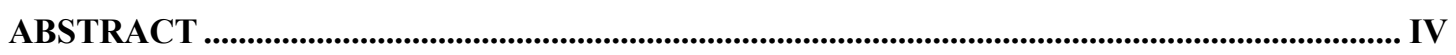

CHAPTER 1- INTRODUCTION ..............................................................................................................

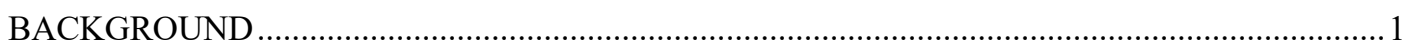

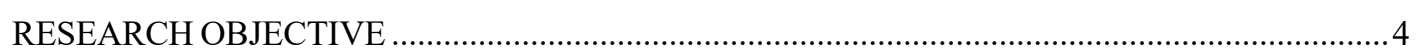

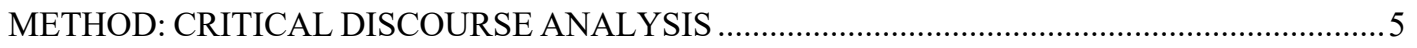

Analytical Framework ..................................................................................................... 7

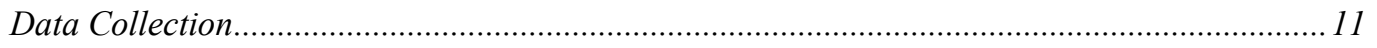

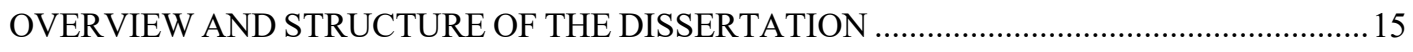

CHAPTER 2- UNDERSTANDING “CITY BRANDING” AND “COMPASSION” "......................24

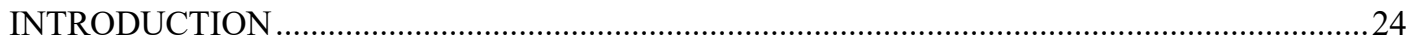

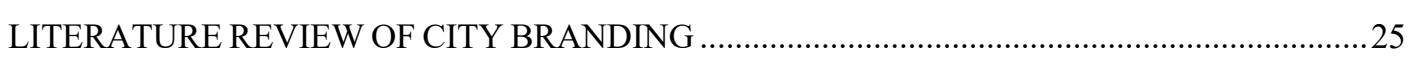

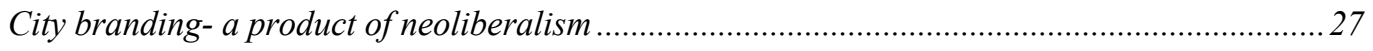

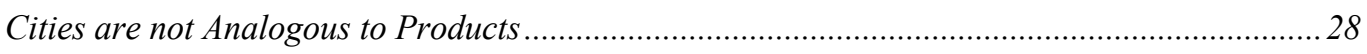

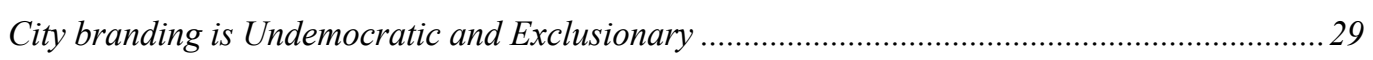

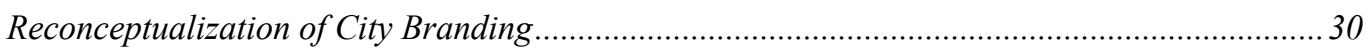

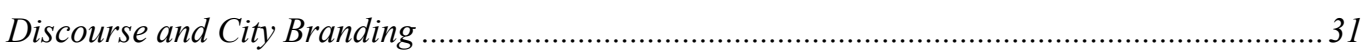

LITERATURE REVIEW OF THE POLITICAL VIRTUE OF COMPASSION .................................. 34

Debates on Compassion as Political Virtue ……………………………………………..... 35

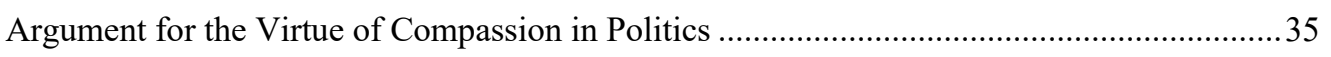

Arguments Against the Virtue of Compassion in Politics ..........................................................4

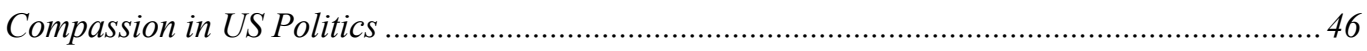

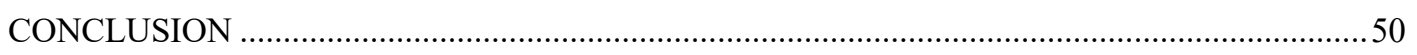

CHAPTER 3 - THE BRAND OF COMPASSIONATE LOUISVILLE.............................................53

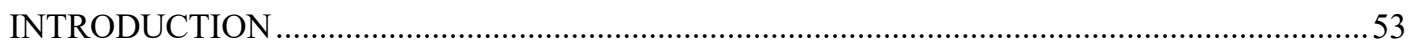

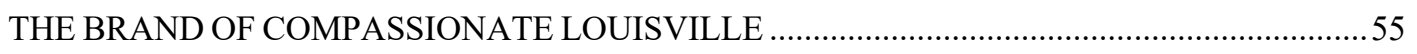

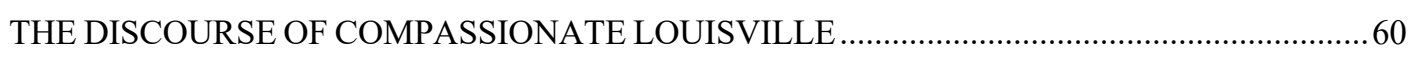

USE OF DISCOURSE OF COMPASSION BY THE CITY GOVERNMENT ……..............................64

Discourse of Compassion in Planning, Programs, and Departments...................................... 64

Discourse of Compassion in Political Debates of Metro Council................................................ 66

USE OF DISCOURSE OF COMPASSION IN POLITICAL STRUGGLES .....................................69 


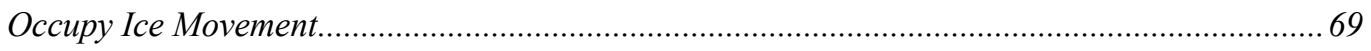

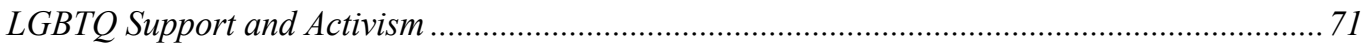

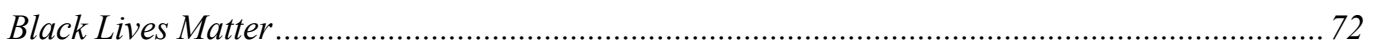

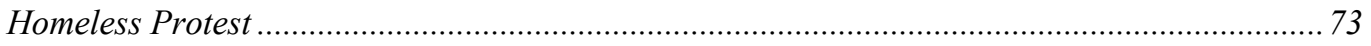

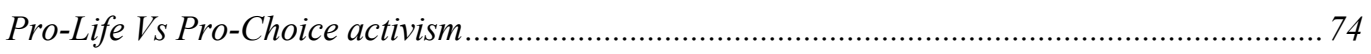

Association with Compassion by Various Organizations........................................................... 75

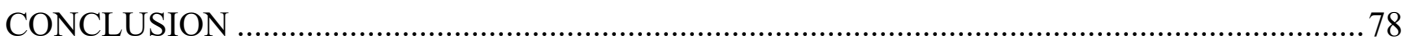

CHAPTER 4 - WHAT DOES COMPASSION DO IN LOUISVILLE? A CRITIQUE OF THE

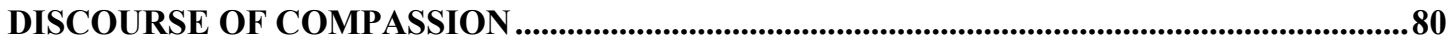

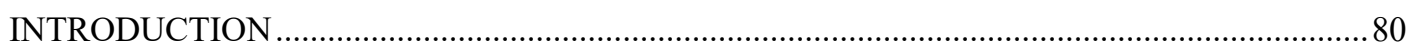

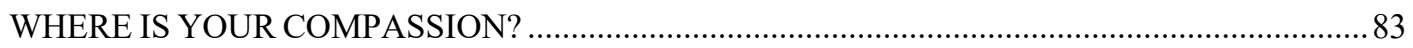

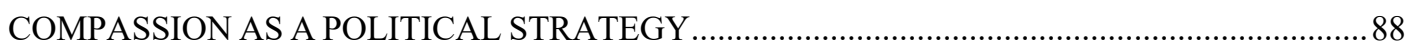

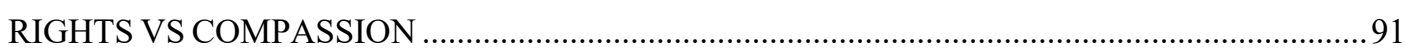

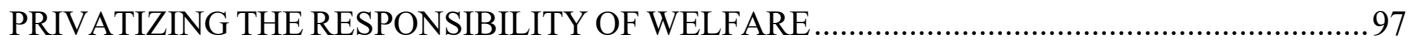

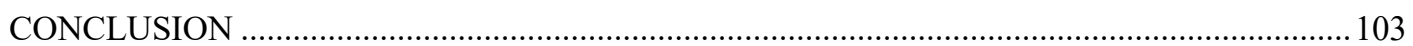

CHAPTER 5 - COMPASSION AS EMOTIONAL GOVERNANCE...........................................106

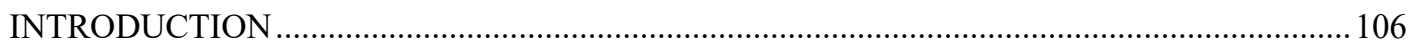

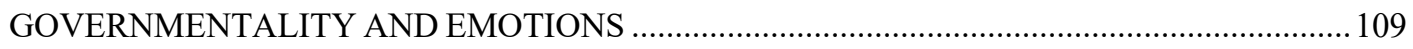

Connecting Governmentality with Emotion............................................................... 112

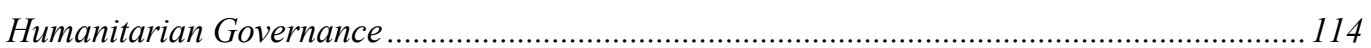

Managing the Precarious Population ..................................................................................... 117

'Creating Emotional Competence ..................................................................................... 119

Compassion as Capital: Extracting Value through Emotions.................................................... 125

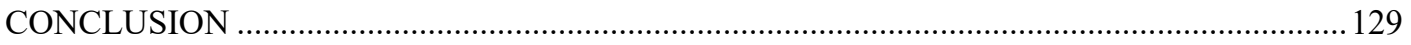

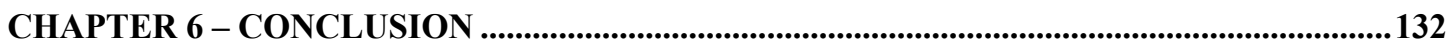

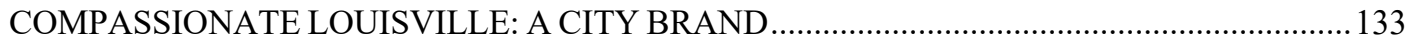

CRITIQUES OF THE DISCOURSE OF COMPASSIONATE LOUISVILLE ............................. 136

COMPASSIONATE LOUISVILLE AS A TOOL OF EMOTIONAL DISCIPLINING.................. 139

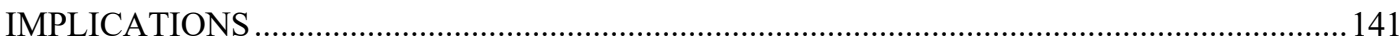

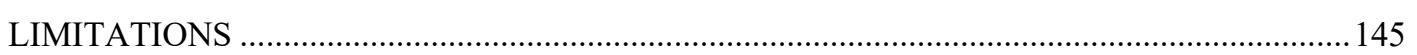

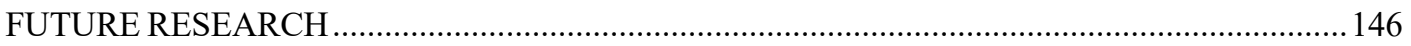

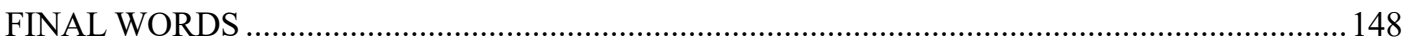

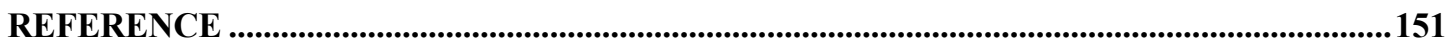

APPENDIX A - OPERATIONALIZING CDA.....................................................................................177

Reflexivity and Positionality of the Researcher.................................................................. 178

APPENDIX B - RESOLUTION OF COMPASSIONATE LOUISVILLE.....................................180 
APPENDIX C - VISION, MISSION AND VALUES OF COMPASSIONATE LOUISVILLE..182 APPENDIX D - MAYOR'S GIVE A DAY PROJECT ................................................................185 APPENDIX E - SUMMARY OF CITY BUDGET ALLOCATION FOR FISCAL YEAR 2020187 APPENDIX F - INTERVIEW TRANSCRIPTS ......................................................................188 APPENDIX G - DOCUMENTS SHARED BY KEY INFORMANTS...............................................207 APPENDIX H - TRANSCRIPT OF LOUISVILLE METRO COUNCIL MEETING MINUTES 


\section{CHAPTER 1- INTRODUCTION}

\section{BACKGROUND}

The dissertation grew from the curiosity of understanding the growing trend of cities declaring themselves as "Compassionate City." The trend is initiated by a nonprofit organization called the Charter for Compassion (referred to as Charter henceforth). The Charter promotes the virtue of compassion- a call to attend the suffering of others. It claims that the virtue of compassion can be subscribed universally regardless of individual differences in belief systems. More importantly, it ascribes this virtue as the highest form of human morality: "It is the path to enlightenment, and indispensable to the creation of a just economy and a peaceful global community" (Charter of Compassion n.d.) ${ }^{1}$. The Charter runs the "Compassionate Communities" campaign ${ }^{2}$ that labels organizations, religious gatherings, neighborhoods, and cities as "compassionate." The campaign has received international attention from various quarters and has been endorsed by a host of global celebrities ${ }^{3}$. Since its inception in 2010, about 90 cities across the world

\footnotetext{
1 "Read, Affirm and Share the Charter," Charter of Compassion, accessed May 20, 2020, retreived from: https://charterforcompassion.org/charter/affirm.

${ }^{2}$ Previously known as International Campaign for Compassionate Cities

${ }^{3}$ Such as Dalai Lama, the Archbishop Desmond Tutu, the Queen of Jordan Noor Al-Hussein, Noble laureate Jody Williams, Noble laureate Marti Ahtisari, late boxing legend Mohammad Ali and several billionaire entrepreneurs like Richard Branson (Virgin Group) and Pierre Morad Omidyar (eBay)
} 
have partnered with the Charter and declared themselves "compassionate, " 50 of which have been in the United States.

The city of Louisville, the site of this research, has been one of the prominent U.S. cities that labels itself "Compassionate." On November 11th 2011, Louisville Metro Council unanimously passed a Resolution to publicly affirm to the Charter and declared itself as the "Compassionate Heart of America" (a copy of the Resolution is attached in Appendix B). For such public declaration, the Charter awarded Louisville the tag of "Model Compassionate City of the World" for five consecutive years from 2012 to 2017. This tag of "Model Compassionate City" brought Louisville major recognition in the regional, national and international circles, even drawing visits of global personalities such as H.H. Dalai Lama in 2013. Since then, the language of compassion has increasingly found a place in the political debates of Louisville. It is used by various social actors including politicians, city officials, Mayor, and activists. The language of compassion has even been evoked in the city's long-term vision: "In 2040, Louisville Metro is a vibrant and diverse community that is connected, healthy, authentic, sustainable and equitable, with compassionate citizens" (LouisvilleJefferson County Metro Government 2019, p 31) ${ }^{4}$.

A burning question is: what is Compassionate Louisville? The city government defines in ambiguous terms:

"Compassion asks us to go where it hurts, to enter into places of pain, to share in brokenness, fear, confusion, and anguish. Compassion challenges us to cry out with those in misery, to mourn with those who are lonely, to weep with those in tears. Compassion requires us to be weak, vulnerable with the vulnerable, and powerless with the powerless. Compassion means full

\footnotetext{
${ }^{4}$ Louisville-Jefferson County Metro Government, Plan 2040: A Comprehensive Plan for Louisville Metro, (Louisville, KY, 2019), 31
} 
immersion in the condition of being human." (Louisville-Jefferson County Metro Government n.d.) ${ }^{5}$.

According to the city websites, the vision of the Compassionate Louisville ${ }^{6}$ includes a range of values such as "Beauty," "Hospitality," "Intention," "Universally Positive," "Abundance," "Transparency," and "Understanding." While these words sound poetic and well-intentioned, they also keep Compassionate Louisville obscure. Is Compassionate Louisville a measure of individual benevolence in the city? Does it mean that city government Louisville has specific goals and targets to alleviate the suffering? Or does "Compassionate Louisville" entail a city-funded department, programs, or projects? A preliminary investigation on Compassionate Louisville shows that it is none of the above. Compassionate Louisville cannot be described as a measure of individual compassion in the city primarily because there is no accounting that defines or tracks individual acts of compassion ${ }^{7}$. It is also not an institutional approach to address the suffering of the marginalized community. Compassionate Louisville is not a city-funded project, program, or department. In fact, there is not a single line of resources from the fiscal budget allocated to Compassionate Louisville.

How can we then describe Compassionate Louisville? To conceptualize Compassionate Louisville, we need to unpack what the signing of the Charter of Compassion means to a city? The Charter does not have any specific policy

\footnotetext{
5 “Compassionate Cities Mission Statement", Louisville-Jefferson County Metro Government, accessed May 20, 2020, retrieved from: https://louisvilleky.gov/government/compassionatecity/compassionate-cities-mission-statement.

${ }^{6}$ See- Appendix C for Vision, Mission and Values of Compassionate Louisville

${ }^{7}$ The Compassionate Cities Index designed by the University of Louisville's Institute for Sustainable Health \& Optimal Aging was an attempt to measure "compassion" in Louisville. The development of Index was announced in December 2016. However, the Index has not been publicly published when this dissertation has been written in 2020. Additionally, Metro United has tracked volunteer hours and frames it as a measure of compassion.
} 
obligations or recommendation that needs to be instituted for its signatory cities. It neither requires any city-funded projects or departments nor provides specific objectives to achieve or goals to accomplish. The only condition the Charter puts is the affirmation to the Charter. This affirmation essentially means only a public announcement by the city government that it has partnered with the Charter. In other words, a public declaration of partnership with the Charter provides cities an instant construction of an image of being "compassionate" without any changes in administration or policy.

In this regard, Compassionate Louisville can be best described as public imagery. It is a label through which the city portrays an image of itself to its residents and to its external stakeholders. In other words, Compassionate Louisville can be conceptualized as a city brand. Recent research on Compassionate Louisville by Ruez \& Parekh (2019) supports this claim. They argue that compassionate Louisville can be best described as an image construction of the city. This dissertation, therefore, takes Compassionate Louisville as a city brand- a deliberate strategy to construct a favorable perception of the city.

\section{RESEARCH OBJECTIVE}

Ruez \& Parekh (2019) claims that the image of Compassionate Louisville can be best understood "in relation to its politics, rather than either the benevolent intentions of its proponents or to theoretical frames that reduce compassion to a singular logic to be critiqued." Following this recommendation, the dissertation does not evaluate Louisville in terms of how "compassionate" the city is. In other words, this dissertation does not seek to evaluate or assess Compassionate Louisville as a program. Nor the dissertation seeks to critique the imagery against the philosophical 
construct of the virtue of compassion. Instead, this dissertation seeks to understand the discursive effect of Compassionate Louisville in relation to the politics of Louisville.

The overall objective of the dissertation is to investigate what the "Compassionate" tag of Louisville does. The dissertation takes Compassionate Louisville as a city brand and seeks to investigate the effect of the image construction on the local politics. To be specific, the dissertation aims to investigate the latent discourses produced by Compassionate Louisville in relation to the neoliberal political economy of the city. The following three interrelated questions guide the research of this dissertation:

- How does the brand of Compassionate Louisville influence the politics of the city?

- What kind of discourses are produced by Compassionate Louisville and how do the discourses situate themselves with the neoliberal political economy of the city?

- What kind of disciplinary regimes are being enacted through the discourses of Compassionate Louisville?

\section{METHOD: CRITICAL DISCOURSE ANALYSIS}

The dissertation employs the method of Critical Discourse Analysis (CDA) to investigate what the brand of "Compassionate Louisville" does. CDA is a qualitative and interpretive method that takes written or spoken language as the object of analysis in relation to its social context. It is a variant of Discourse Analysis and used in a variety of disciplines in the social sciences, especially in the studies governmentality. CDA seeks: 'to systematically explore often opaque relationships of causality and determination between (a) discursive practices, events and texts, and (b) wider social 
and cultural structures, relations and processes; to investigate how such practices, events and texts arise out of and are ideologically shaped by relations of power and struggles over power' (Fairclough, 1995, 132). CDA assumes that latent structures, ideologies, and politics are entrenched in society through the production and use of discourses (van Dijk, 2001; Meyer, 2001; Wodak, 2001). It investigates how practices and language arise out of ideology by investigating the hidden relationships of discursive practices, language, and wider social structures (Locke 2004).

CDA assumes that our social and political actions are mediated through discourse (Farrelly, 2010). The concept of discourse in CDA is an aid to understanding the way societies organize and be organized by the use of language (Farrelly, 2010). Each discursive site of a society has a range of possible language utterances, which essentially limit and govern its subjective, epistemic, and ethical production (McKenna, 2004). This creates a phenomenological objective reality that shapes practices, systems, and knowledge (Schwak, 2016; McKenna, 2004). In the process, discourse shapes social truths and rationalities (Foucault, 2004; Deleuze, 2004). Discourses are not mere tools of expression that describes the world, but rather provide the meaning to it (Fairclough, 1985). CDA, therefore, explains texts in the context of power-relations it is produced and consumed (Richardson, 2007).

CDA is a useful methodology to study governmentality because it constitutes a theoretical perspective that normatively critiques capitalism's role in reproducing social relations. CDA investigates how discourse is used to constitute and legitimize inequality, disparity, marginalization, discrimination, dominance, and power (Wodak, 2001; Fairclough, 1992; Amoussou \& Allagbe, 2018; Powers 2007). It probes the role of discourse in the production and maintenance of social rationalities that govern people in the neoliberal political economy. In the process, CDA reveals the latent 
structures and ideologies entrenched in society that reproduces and legitimizes social order required for capitalism (Fairclough, 2001; McKenna, 2004; Jäger, 2001; van Dijk, 2001; Meyer, 2001; Wodak, 2001)

This dissertation employs the CDA methodological approach to study the discourse produced by Compassionate Louisville. It seeks to understand how the latent discourse of compassion influences the socio-politics of Louisville. Compassionate Louisville, being a brand, produces a certain social discourse of compassion. The CDA methodological approach helps to investigate this manufactured discourse in relation to the socio-political context of the city. It helps to examine questions such as: What is the discourse of compassion serving in Louisville? What is being represented here as truth, norm, and social rationalities? What are the materials, practices, and power relationships that are assumed by it and sustained through it? What evidence and assumptions are being used? What alternative meanings/explanations are being ignored? What kind of personal and group identities does it promote? More importantly, what social regime does the discourse helps to enact?

\section{Analytical Framework}

Critical Discourse Analysis is considered both a method and an analytical framework (Fairclough, 2001). At the heart of the CDA approach lies the critical theory that posits language as a manifestation of structural power relationships in society. Critical theory is a distinctive form of epistemology that has derived from the idealism of the Frankfurt School of Philosophy and Marxism. It opposes the traditional philosophy of scientific knowledge that only seeks to investigate the world in an objective manner. Instead, the critical theory posits that knowledge is subjective, 
contextual, and produced in relation to power. Geuss (1981) articulates this

epistemological distinction:

A critical theory is structurally different from a scientific theory in that it is "reflective" and not a "objectifying", that is, it is not just a theory about some objects different from itself, it is also a theory about social theories, how they arise, how they can be applied, and the conditions under which they are acceptable (pg. 79).

The concept of "critique" is an essential feature of this tradition as it sets to unveil the ideologies under which the knowledge is embedded. Ideology, as understood here, is a system of ideas, beliefs, and mental frameworks that produce and legitimize the social order. Thus, the critical theory seeks to comprehend the hidden set of social cognitive arrangement that constitutes how we see society. It involves a thorough social criticism with normative judgments and evaluation that unpacks the ideologies existing in the society. Specifically, it seeks to describe the ways ideology produces and legitimizes power, hegemony, and domination of the privileged group over the marginalized class (Habermas 1985; Brenner 2009; Thompson 2017; Gramsci 1971; Bourdieu 1990).

This component of "critique" makes CDA an analytical framework (Fairclough, 2001). CDA assumes that discourses are the medium through which ideologies are produced, transformed, resisted, and legitimized. CDA, therefore, seeks to investigate hidden ideologies that are entrenched in discourse. It analyzes textual data to understand how meaning is constructed and mobilized through discursive practices, especially in how it maintains relations of power (Thompson 1990; Chouliaraki and Fairclough 2002; Fairclough 1992; Sriwimon and Zilli 2017; Fairclough and Wodak 1997). Applied to this project, the critical epistemology helps to understand the subtle ways in which structural power creeps in unwittingly upon those engaged in promoting social good (such as compassion). It renders the analysis of text to understand what kind of discourses are produced by the Compassionate 
Louisville? What is being represented here as truth, norm, or social rationalities? How these social rationalities positions in relation to the overall political economy (neoliberal) of Louisville?

Another analytical framework that undergirds the analysis of this dissertation stems from the critique of neoliberalism. Neoliberalism, as understood in this dissertation, is a political philosophy deeply vested in economic liberalization that subordinates state power to the market requirement. The key assumption of neoliberalism is that society is based on self-interested individuals who make the rational choice between given options, maximize their own utility, and act independently based on the information in hand (Scott \& Storper, 2014; Weintraub, 1985; Barber, 1984). It further assumes that people's desires are so diverse that the only way to account for all diverse demands is through a market-based politicaleconomic system - an ontology that allocative efficiency in society can be maximized only through market forces of demand and supply (Macpherson, 1977). It is a postwelfare political system that is modeled on the principles of entrepreneurialism, where society relies on market forces to address political problems. Signature policies associated with neoliberalism include privatization, deregulation, marketization, structural adjustment, and austerity (Peck 2017). These market measures are legitimized through the deployment of market ideology that becomes a normative framework for citizens to think and make decisions. In other words, neoliberalism operates and perpetuates by producing neoliberal subjectivity where individuals operate as a miniature firm- responsible for their own welfare, responds to incentives, and takes decisions based on economic logics (Vincent, 2010; Peck 2010; Schecter 2010; Larner 2006; Ferguson 2010; Hall 2011; Harvey 2007; Dawes and Lenormand 2019; Protevi 2009). CDA inherently critiques the neoliberal political structures and 
ideologies that perpetuate capitalism. This framework forms the researcher's normative position, which views the structure of neoliberalism as totalitarian, oppressive, and discriminatory (also see Reflexivity and Positionality of the Researcher in Appendix A).

Essentially, the texts of the dataset are analyzed to establish a connection to the neoliberal political economy of Louisville. It critiques Compassionate Louisville and its discourse as a broader critique of neoliberal governance. The premise of this argument made is that the development of a specific emotional configuration is integral for neoliberalism to function and be acceptable. The discourse of compassion is deployed as a tool to aid in the management of this emotional configuration. The brand of Compassionate Louisville is seen in this dissertation as a technology of neoliberal governmentality. Its ultimate motive is to discipline the emotion in a manner that conforms with broader neoliberal social logic. In other words, the discourse of compassion in Louisville originates and operates in the social context of neoliberalism, and consequently, it works to further entrench the oppressive structure.

There is no one rule or procedure for analyzing the data (Mogashoa 2014). This dissertation follows the three-step framework of CDA prescribed by Fairclough's $(1989,1995)$. The framework involves analysis of texts, interactions, and social practices at the local, institutional, and societal levels. The benefit of this framework is that it allows focuses on the relationships among texts, interactions, and social practices. This relationship is then interpreted to understand the configuration of ideologies latent in the discourse. It allows explanations of why and how social practices are constituted, contested, and changed by the use of discourse. Appendix A provides details on how the framework has been operationalized for this dissertation. 


\section{Data Collection}

The dissertation involves a textual analysis of archived documents related to Compassionate Louisville and a limited number of interviews of key informants. It is important to note here that data collection through interviews has been a major challenge for this dissertation. Compassionate Louisville is not a city-funded department, program, or project. Instead, Compassionate Louisville is an imagery, a city brand that is constructed through an amalgamation of communications by multiple city officials, non-profit organizations, and politicians. In other words, there are no designated city employees responsible for Compassionate Louisville, which entails that there is no readily identifiable list of the potential interviewees ${ }^{8}$. In this regard, the initial plan for data collection involved a strategy of interviewing key informants through which relevant interviewees will be identified in a snowball sampling approach.

Therefore, the data collection started with semi-structured interviews of two key informants related to Compassionate Louisville. The first key informant served as the Director of the International Compassionate Cities Program of the Charter for Compassion. He has been considered as a key informant because of his direct involvement in designing the Compassionate City initiatives for the Charter. He has also closely worked with the Mayor Fischer's administration for Louisville's affirmation to the Charter. The second key informant interviewed for the dissertation was a volunteer of the Charter of Compassion. This interviewee has been considered

\footnotetext{
${ }^{8}$ Special Assistant to the Mayor, Janice Cates, (previously Brenda Frank) coordinates with Charter of Compassion, various non-profit organizations, and volunteers for "compassionate initiatives." However, their role is more of a volunteer and ambassador for compassion. The researcher unsuccessfully attempted several times to organize an interview with Janice Cates.
} 
as a key informant because he acted as a liaison between the Charter and the city government of Louisville. He has been part of the initiatives of Compassionate Louisville since its inception. He has also formed an informal volunteer group that advocates for the value of compassion in the city. These interviews provided valuable insights on the relationship between the Charter and city administration. It also helped to understand the socio-political context of development and maintenance of the brand of Compassionate Louisville. Additionally, the interviews provided helped to identify potential interviewees who are relevant to understanding Compassionate Louisville. The list of potential interviewees included city government officials, members of the Metro Council, leaders of non-profit organizations, business enterprises, and several activists.

However, this process of collecting data through interviews was halted in March 2020 due to the public health crisis of COVID-19. In response to the pandemic, the University of Louisville directed suspension of all "non-essential" community-based research activity from early $\operatorname{March}^{9}$. More importantly, all interviewees canceled their scheduled appointments of interviews citing their priority of managing the public health crisis. Therefore, the dissertation could not collect additional data through interviews beyond the two conducted.

In response to this drawback, the dissertation adopted the approach to conduct a comprehensive survey of archived data related to Compassionate Louisville. Data

\footnotetext{
9 The memo of the suspension of non-essential research is available in the following link: https://louisville.edu/research/covid19resources/from-the-evpri-remote-work-guidelines-for-theuniversity-of-louisville-research-community
} 
collection is an iterative process in the CDA - where analysis of the initial data provides concepts and categories that leads to new data collection (Meyer, 2001). Following this approach, the dissertation first surveyed publicly available text from relevant city government reports, planning documents, ordinances, resolutions, annual financial reports, and websites. Additionally, the dataset includes texts from reports and websites of relevant non-profit organizations that actively use the language of compassion. Second, the dissertation surveyed the meeting minutes of Metro Council from October 2011 to March of 2020 to identify instances where the narrative of compassion was used. These documents play a crucial and normative role in disseminating knowledge and truth claims regarding Compassionate Louisville. According to Fairclough (1992), such institutional documents contain latent power relations and ideologies that shape the discourses of Compassionate Louisville. It also indicates how the discourse of compassion is being constructed and used as a logic in political debates, negotiation, and legitimations of claims.

Third, the dissertation surveyed published media articles relevant to Compassionate Louisville in local newspapers from 2010 to March 2020. The dataset includes publications from Louisville Courier-Journal, WFPL, LEO Weekly, WDRB, Spectrum News, Wave3, and Insider Louisville. Scholars such as van Dijk (2001), Fairclough (2001), Fowler (1991), and Richardson (2007) claim that such textual content in published media reflects ideological interests and stances. They argue that media publications help to reproduce power relations in society by naturalizing the discourse as "common sense" knowledge. In this regard, this dataset of newspaper media helps to understand how the discourse of compassion is being produced and made acceptable. Along with that, the textual dataset also includes documents shared by key informants. These documents are not publicly available and include 
communication materials between the Charter and the city of Louisville. It allows the examination of the latent ideological ground of the discourse of compassion.

Such comprehensive surveying of archived documents compensates for the data loss (interview) due to the COVID19 pandemic. The large textual dataset from almost all publicly available archived documents also lends robustness and credibility to the dissertation. The following table summarizes the textual datasets used in this dissertation.

\section{Table 1: Summary of dataset used for CDA}

\begin{tabular}{|c|c|c|}
\hline $\begin{array}{l}\text { Data Collection } \\
\text { Tools }\end{array}$ & Data types & Dataset \\
\hline $\begin{array}{l}\text { Semi-structured } \\
\text { interview }\end{array}$ & $\begin{array}{l}\text { Interview text of } \\
\text { two key informants }\end{array}$ & $\begin{array}{l}\text { The transcript of the data is attached in } \\
\text { Appendix F }\end{array}$ \\
\hline \multirow{3}{*}{ Archived data } & Media Articles & $\begin{array}{l}\text { Media article from } 2010 \text { to March } 2020 \\
\text { were surveyed for the following local } \\
\text { publications: Courier-Journal, WFPL, } \\
\text { LEO Weekly, WDRB, Spectrum News, } \\
\text { Wave3, and Insider Louisville. } \\
\text { These articles include local news, } \\
\text { published opinions, media reports, and } \\
\text { interviews. }\end{array}$ \\
\hline & $\begin{array}{l}\text { Governments } \\
\text { Reports }\end{array}$ & $\begin{array}{l}\text { The dataset includes reports from the } \\
\text { following government reports: Vision } \\
\text { Louisville 2040, Louisville's Blueprint for } \\
\text { Safe and Healthy Neighborhoods (Phase } 1 \\
\text { and 2), Progress Reports (2011-2018), } \\
\text { Mayor Fischer's 100-Day Plan, Louisville } \\
\text { Metro's Strategic Plans, Annual Budget } \\
\text { reports (2011 -2020), City Marketing Plan } \\
\text { 2017, Branding Guideline Report 2018. }\end{array}$ \\
\hline & $\begin{array}{l}\text { Government } \\
\text { Website }\end{array}$ & $\begin{array}{l}\text { The dataset includes texts from the } \\
\text { following websites: Louisville-Jefferson } \\
\text { County Metro Government, Tourism } \\
\text { department GotoLouisville, } \\
\text { Emergency Services, Health \& Wellness, } \\
\text { Louisville Forward, office of Mayor Greg } \\
\text { Fischer, Resilience and Community } \\
\text { Services and LMPD. }\end{array}$ \\
\hline
\end{tabular}




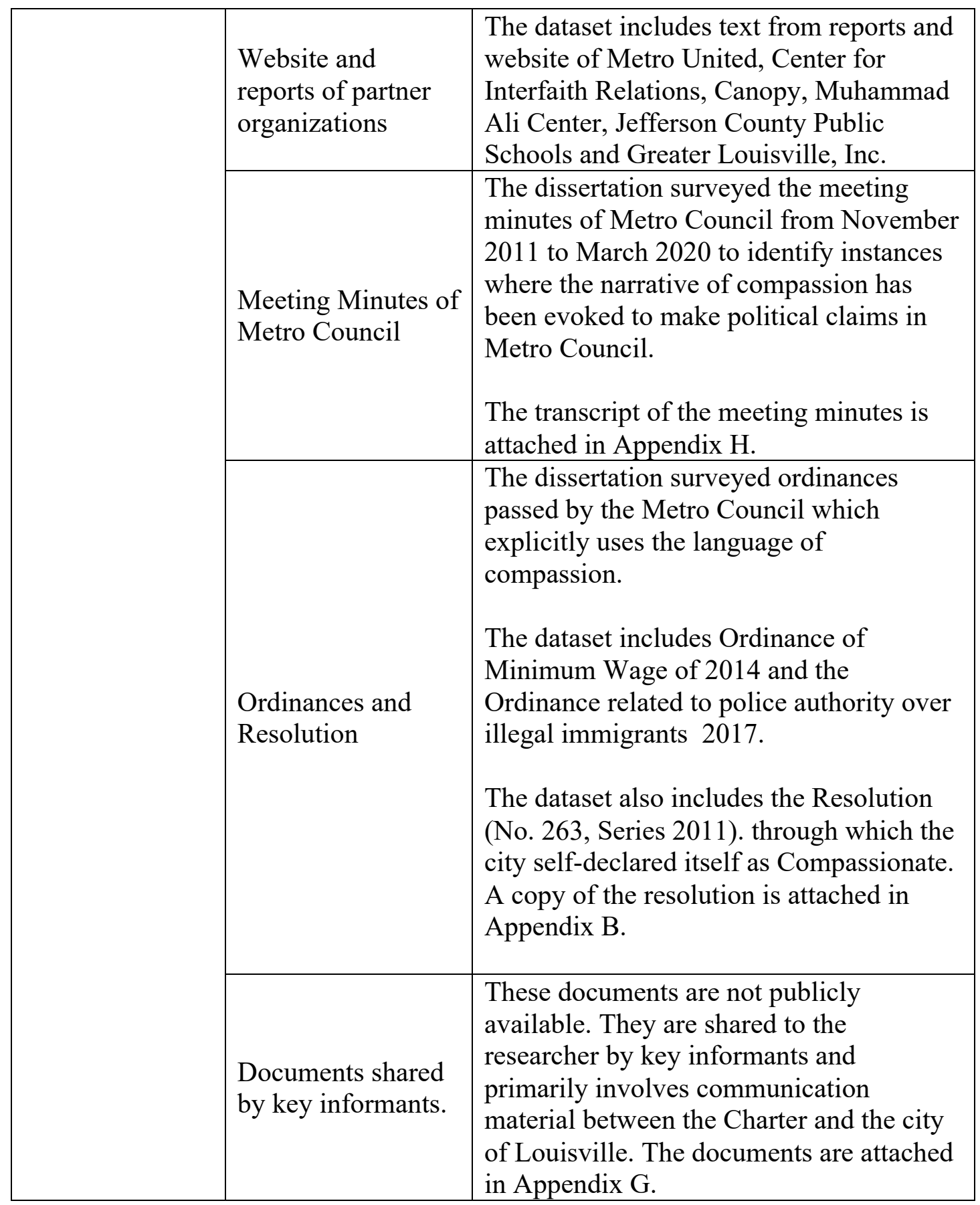

\section{OVERVIEW AND STRUCTURE OF THE DISSERTATION}

The dissertation is a critique of the discourse produced by Compassionate Louisville. It is inspired by Ruez \& Parekh's (2019) study on the same topic who claims that compassion in Louisville is politically constituted, mediated, and 
contested. The dissertation takes this research further by critically investigating the discourse produced by the brand in relation to the overall neoliberal political economy of the city. There are three novel and interrelated findings of this dissertation. First, the discourse produced by Compassionate Louisville is increasingly becoming a logic through which various actors frame political positions, debates, and claims. Second, this discourse of compassion tends to moralize neoliberal strategies of privatizing welfare. In the process, it depoliticizes social problems, displaces rights, and entrenches the precarity of the communities. Third, the discourse of compassion is an urban version of humanitarian governance that acts as a technology of neoliberalism. It disciplines the emotions of the peoples to entrench neoliberal subjectivity in the disguise of a humanitarian narrative. These findings help new conceptualization of city branding, where the urban image-making process is seen as a form of emotional governance and formation of neoliberal self-regulating citizens.

Along with this introductory chapter, the dissertation is organized in six chapters. The following provides a brief overview of each of the chapters.

\section{Chapter 2}

Chapter 2 surveys two distinct branches of scholarship that traditionally do not have many intersections: city branding from the field of Urban Studies, and "compassion" as political virtue from the scholarships of Political Philosophy. The literature of city branding typically takes branding as an urban policy instrument that seeks to manufacture a distinct image of a city and its residents to gain competitiveness. In other words, it is a communication tool to attract capital. While this is true, there is a gap in the literature on how such engineered image-making can influence urban politics. In particular, how a city brand can promote emotions and 
virtues, such as compassion, is understudied. In this regard, the chapter establishes a conceptual relationship with city branding and political discourse. It argues that the city branding, in order to manufacture an image, produces a discourse of what city aspires to be. This engineered discourse has the potency to entangle in the broader political narrative of the city and consequently influence politics. This conceptual relationship of discourse and city branding is used in Chapter 3 as an analytical lens to claim that Compassionate Louisville manufactures a discourse of compassion in the city whose logic is being increasingly used in policy rationales, contestation, debates, and claim-making.

The second part of chapter 2 reviews the literature of compassion as a political virtue. This review helps to contextualize the discourse of Compassionate Louisville with the broader use of the rhetoric of compassion in US politics. It presents the arguments that the narrative of compassion has been subtly present in various political debates of the US. The review shows that the discourse of compassion in the US has been compatible with its neoliberal political economy - it calls for the deployment of welfare not through government but through private philanthropy. The chapter also reviews the literature that critiques the presence of the virtue of compassion in public affairs. Compassion is argued to be incompatible with the notion of justice and rights. Additionally, the narrative of compassion is critiqued for being part of emotional disciplining that entrenches neoliberalism in the disguise of humanitarian sensibilities. This literature survey helps to contextualize the Compassionate Louisville brand as a neoliberal project in the overall analysis of this dissertation. It also provides the analytical categories to critique the discourse of Compassionate Louisville in chapter 4 and chapter 5 . 


\section{Chapter 3}

Chapter 3 of this dissertation seeks to explain what "Compassionate Louisville" is. It makes two broad arguments. First, the chapter claims that "Compassionate Louisville" is a manufactured imagery - a city brand. What gave Louisville the tag of "Compassionate" is the public affirmation to the Charter of Compassion, through which it declares itself as the "Compassionate Heart of America." Apart from this self-declaration and its political rhetoric, "Compassionate Louisville" does not have any concrete administrative presence. Compassionate Louisville is not a government-funded program or a department; it does not have any specific goals, measurable targets, employees, or a single line of budget allocation. Instead, this chapter argues that "Compassionate Louisville" can be best described as a portrayal of an image to its residents and to its external stakeholders. It is a manufactured imagery- a city brand that engineers an image of being empathetic, benevolent, and moral.

Second, Chapter 3 argues that the brand of "Compassionate Louisville" is not a docile and apolitical slogan of the government. City brand is often conceptualized as a passive marketing strategy or a boosterism policy that renders very little effect on local politics. However, this chapter argues the brand of "Compassionate Louisville" is increasingly having an impact on local politics by generating a discourse of compassion. To manufacture and maintain the imagery of "compassionate," the city produces a discourse that calls individuals acts of compassion. It glorifies the acts of benevolence as spiritual, honorable, and moral. More importantly, it propagates the idea that individual compassionate agents can resolve the social problems that plague Louisville. This manufactured discourse of compassion is increasingly becoming a 
new political logic in the city through which debates are mediated, negotiated, contested, and accepted.

To support this claim of the political agency of "Compassionate Louisville," the chapter outlines cases where the discourse of compassion has been used by politicians, city officials, religious organizations, activists, non-profits, and businesses. It shows that the narrative of compassion is frequently evoked as the vision statements of various planning documents. Additionally, it has also been used in a wide range of political debates in the Metro Council including that of fiscal budget, minimum wage, public safety, economic development, homelessness, affordable housing, health equity, sanctuary city, animal rights, parks, cannabis legalization, and COVID-19 response. The discourse of compassion is also used by activists to make political claims in a wide range of issues such as LGBTQ rights, racial justice, homelessness, immigrant rights movement, and abortion rights activism. These citizen-led movements that have a presence in almost all US cities typically make their claims on the grounds of rights, fairness, and justice. However, chapter 3 shows that these same political struggles in Louisville have used the discourse of compassion in conjunction with the usual logic of rights and justice. These cases show that the discourse of compassion is becoming a new political logic that influences the planning, policy-making, and overall politics of Louisville.

\section{Chapter 4}

Chapter 4 of the dissertation critiques the discourse of compassion and the use of its logics in Louisville. The discourse produced by the Compassionate Louisville propagates the idea that individual compassion is not only a moral virtue that everyone should have but also the solution to the social issues of the 
city. This chapter argues that compassion is not necessarily an elixir: it cannot and does not address the social problems of Louisville, such as inequality, poverty, homelessness, health disparity, and racial segregation. Instead, the narrative of compassion helps to produce and reproduce the asymmetries of Louisville in the disguise of solving them.

Chapter 4 argues that the discourse of compassion shifts the responsibility of issues of welfare provision, distributional equity, and social justice away from public affairs to private affairs. It responsiblizes individuals for taking care of the distressed and marginalized through philanthropy. Moreover, the chapter argues that individual compassion alone is inadequate to address the social problems of Louisville, largely because larger structural circuits of neoliberalism perpetuate these issues. In other words, social issues cannot simply be addressed by acts of individual compassion without the change of public policies that produce them.

Additionally, the shift of social responsibility away from government to "compassionate" individuals depoliticizes the sufferings experienced by the marginalized communities. This depoliticizing move allows the city government of Louisville to wash its hands off from the responsibility of delivering welfare and social justice. It effectively strips the political rights of the marginalized communities to demand the alleviation of their sufferings- that their distress should be addressed not out of the mercy of someone but because of their right as a citizen. It dismantles the notion that issues such as marginalization, poverty, inequity, and suffering are a matter of social justice that calls for collective and institutional actions. It leaves marginalized communities in a state of precarity where they do not have any guarantee of alleviation of their suffering. 
Taking these arguments together, the chapter claims that the discourse of compassion does not address Louisville's chronic social problems. On the contrary, it helps to aggravate them through the further entrenchment of neoliberalism in Louisville. The approach of 'rolling-up' the government's responsibility for welfare provision to individuals and business actors is a trademark neoliberal strategy. The discourse produced by the Compassion in Louisville helps to moralize neoliberal strategies that depoliticize social problems, displaces rights, and reproduces precarious communities.

\section{Chapter 5}

Chapter 5 of this dissertation explores the question of what kind of disciplinary regime the discourse of compassion produces. The overall argument of this chapter is that the brand of Compassionate Louisville is a tool of neoliberal governmentality that disciplines the emotions of Louisville. This chapter first establishes a relationship with emotions, neoliberalism, and the brand of Compassionate Louisville. It argues that a certain set of emotional configurations is required for the neoliberal political economy to be functional and acceptable. In this regard, emotions become an object of state governance that is achieved by deploying governmental technologies that guide individuals to experience certain emotions that are 'productive' while inhibiting emotions that are threatening to circuits of productions. The recent trend of humanitarian narrative in public affairs is argued to be one such approach to discipline the emotion of the populations.

Chapter 5 then argues that Compassionate Louisville is an urban version of humanitarian governance and acts as a technology of neoliberalism. It governs 
the emotions of the people by deploying a particular discourse of compassion. The chapter makes three claims on the governance of emotions by

Compassionate Louisville: (a) it serves to manage the marginalized population of the city; (b) it works to discipline emotions to make the working population more productive and compliant; and (c) it creates the ground to transform the emotions of people into a productive asset, a form of capital through which value can be extracted. Compassionate Louisville, thus, works the work of capital- an extension of overall neoliberal governmentality in the disguise of a humanitarian narrative.

\section{Chapter 6}

Chapter 6 is the concluding chapter of the dissertation. It summarizes the findings of this dissertation and identifies the limitations it may have. The chapter also outlines possible future research this dissertation may lead to. Most importantly, the chapter identifies the broader implications of the findings. It argues that the findings open up new conceptualization of city branding, where the image-making process is seen as a potent technology of governmentality. It also provides insight on state governance of emotions at the urban scale that contributes to the formation of self-regulating citizens. In the broader sense, the findings indicate that urban neoliberal governance is not only about cold economic reasonings; it also involves a degree of emotional subjectification of the residents of the city. Additionally, the finding points that humanitarian narratives in politics such as care, compassion or empathy should be studied in the political context that generates and perpetuates them. When analyzed within the political context, these lofty ideals of humanitarianism do not always hold to 
the popular moral perception they carry. Instead, the humanitarian narratives tend to be subservient to the dominant discourse of neoliberalism. 


\section{CHAPTER 2- UNDERSTANDING “CITY BRANDING” AND "COMPASSION"}

\section{INTRODUCTION}

An overarching theme of this dissertation is that the Compassionate Louisville is a "city brand". Unlike the popular notion that a brand is just a promotional tool with catchy slogans and logos, this dissertation argues that the brand of Compassionate Louisville has significant influence on the politics of the city. It does so by propagating a discourse in the city which calls to cultivate the virtue of compassion. This dissertation seeks to investigate the effects of discourse, produced by the brand of Compassionate Louisville, on socio-politics of the city. In this regard, this chapter reviews two distinct branches of scholarship: City Branding from a broader tradition of Place Marketing, and compassion as a political virtue from the field of Political Science.

The chapter is divided into two broad segments. The first part reviews the literature on city branding. This literature strictly sees city branding as a neoliberal policy instrument to attract capital. Critical scholarship on city branding can be clustered into understanding (i) how cities are branded and (ii) why cities are branded. This section highlights the scarcity of academic scholarships discussing socio-political effects of city branding. A topic particularly understudied is how a city brand promotes a political virtue such as compassion. Additionally, this section establishes a conceptual relationship of political discourse and city brands. 
The second part of the chapter reviews the literature of compassion as a political virtue. This review helps to contextualize the discourse of Compassionate Louisville with the broader use of the rhetoric of compassion in US politics. It argues that the narrative of compassion subsumes in various policies and debates in subtle ways. Moreover, it claims Republican President George W. Bush has popularized the concept of "Compassionate Conservatism", an idea which calls for the deployment of welfare not through government but through religious actors. Additionally, the review also seeks to outline a theoretical lens that critiques the political virtue of compassion. It identifies two broad critiques of public compassion: (a) it is incompatibility to the notion of justice; and (b) it is a tool of governmentality that entrenches neoliberalism in the disguise of humanitarian sensibilities.

\section{LITERATURE REVIEW OF CITY BRANDING}

Neoliberalism ${ }^{10}$ has resulted in an urban governance system with the hegemony of market rationality in city politics. It has brought about a belief that urban problems can be translated into economic equations of demand and supply, with the perpetual infusion of capital being the primary solution to social problems. This brings about entrepreneurialism in urban governance, where cities are being run like businesses and are in constant need to attract capital (Harvey 1989; Hubbard and Hall 1998; Peck, 2014; Abrahamsson and Ek 2014; Rossi and Vanolo 2015; Cleave \& Arku 2015). In the process, cities are commodified to be sold in a competitive market

\footnotetext{
${ }^{10}$ Neoliberalism is an umbrella term conceptualized and applied in various ways: from a programmatic bundle of pro-market policy measures; to the rationality of small-government; to a belief system of market fundamentalism; and to a historical change of capitalist development of global north. It is a political economy where society relies on market forces to address political problems (Peck 2017).
} 
in a bid to attract investment (Eshuis \& Edwards 2013; Greenop \& Darchen 2016). Globalization of capital has further accentuated this phenomenon, where cities across the world are in hyper-competition with each other to attract capital (Eshuis \& Edwards, 2013). City branding is argued to be one of the policies that are deployed in this pursuit of capital in the hyper-competitive market (Eshuis \& Edwards, 2013).

In this view point, the primary objective of city branding is to define and manage a favorable perception to gain a competitive advantage in the intercity capital market (Kavaratzis \& Ashworth, 2009; Hernandez \& Lopez, 2011). In a bid to compete in the market, cities across the world have undertaken similar strategies: offering analogous services, infrastructure, communication, and incentives. Such homogenized policy and service offerings across competing cities eliminates the competitive advantage of a city over another (Cleave \& Arku 2015). Branding provides a solution to this issue by creating differentiation between the competing cities through forging a unique perception or image. Branding helps to manufacture an unique reputation of the city that provides an additional dimension to the attractiveness in the capital market (Johansson 2012; Khirfan and Momani 2013). Place branding scholars draw most city branding concepts from corporate branding (Anholt, 2005; Therkelsen \& Halkier, 2008; Kavaratzis \& Ashworth, 2009; Oguztimur \& Akturan, 2015). Corporate branding is a process of collective strategymaking of an organization on its vision, purpose, beliefs, culture, and ethics (Anholt, 2005). It shapes the visual, verbal, and behavioral expression of the organization (Simoes \& Dibb, 2001). Corporate branding entails that an entire organization is branded, under which individual entities and products are allowed to brand itself separately as long as it is consistent with the overarching corporate identity. Unlike product brands, corporate brands deal with larger questions such as social 
responsibility, sustainability, and identity (Kavaratzis \& Ashworth, 2005). Branding scholars (Anholt, 2005; Therkelsen and Halkier, 2008; Kavaratzis \& Ashworth, 2009; Kavaratzis \& Ashworth, 2005) claim there are similarities between corporate branding and city branding in the sense they both deal with collective strategymaking of multiple stakeholders (Ashworth 2001), form collective identities with room for individuality (Kavaratzis \& Ashworth, 2005; Dematteis, 1994), and account for social responsibility (Kavaratzis, 2009; Ave, 1994).

In the last two decades, the practice of branding cities has gained prominence across the world (Green et al., 2016; Oguztimur \& Akturan, 2015; Papadopoulos, 2004). The following is a brief summary of the literature of city branding from a critical perspective.

\section{City branding- a product of neoliberalism}

Scholars have been critical of city branding for being a neoliberal project that attempts to commodify the city to market to investors, tourists, and new residents (Eshuis \& Edwards, 2013; Harvey, 1989). This commodification of the city makes the city a profit-making endeavor that ignores the historical, cultural, and social issues of the city (Boland, 2013). Additionally, being a product of the neoliberal political system, city branding shares the same critique of the neoliberal urban governancesocial marginalization, displacement, and gentrification (Dinardi, 2017). Paganoni (2012), for example, demonstrates through her research in 12 UK cities that there is a gap between the communicated image of the city and the actual reality. She claims that the narrative of city brand is self-congratulatory, and behind that narrative remains the abject disregard for poor people of the city. Kipfer \& Keil (2002), through their research on the branding of Toronto to become a 'competitive city', find 
the branding strategy led to the practices that paved the way for prominence of large companies in city development, eventually leading to inequity and exclusion. Rousseau's (2009) account of industrial cities in the UK and France shows that city branding targeting the middle-class in the city center eventually results in the gentrification of the urban poor.

\section{Cities are not Analogous to Products}

Concepts of the city branding practices are heavily drawn from broader conversations of product/corporate brand management literature (Ashworth \& Voogd, 1995; Giovanardi, Lucarelli, \& Pasquinelli, 2013; Colomb \& Kalandides, 2010). A brand symbolizes the summation of physical attributes, emotional associations, and beliefs related to what is branded (Simoes \& Dibb 2001). However, this transposition of product branding concepts to describe city branding has been contested by some scholars (Lucarelli \& Berg, 2011; Braun, 2011; Freire, 2005; Giovanardi et al., 2013). The premise of their argument is that product branding strategies cannot simply be transposed to cities because cities have a more complex web of interrelated and diverse stakeholders. Positioning a single notion of the city brand identity is problematic to the diverse range of people a city typically holds. Moreover, Braun (2011) and Freire (2005) claim that individuals develop their own image of the city independently - 'organically'. Each individual has a personal image of the city as they navigate the city across time and space (Castillo-Villar, 2018). The factors influencing the city image are autonomous, diverse and innumerable, ranging from individual first-hand experiences of the city, interactions with other residents, word-of-mouth, media to literature, arts and history (Ashworth, 2009; Blichfeldt, 2005; Kapferer, 2011). These factors are so diverse, and the individual responses to these factors are 
so unique that the city's image develops randomly, chaotically, and autonomously in the mind of its residents (Parkerson, 2007). Therefore, unlike product brands which can be forged as one identity from the beginning, the city's image differs at the individual level (Giovanardi et al., 2013), making it a more complex endeavor than product branding.

\section{City branding is Undemocratic and Exclusionary}

City branding has also been critiqued in the literature for being an undemocratic and exclusionary practice (Eshuis \& Edwards, 2013; Greenop \& Darchen, 2016; Insch, 2001). Critical scholars have argued that the processes of city branding have largely been top-down, opaque, non-participatory and unaccountable to people. Bennett \& Savani (2003), for example, through their studies of nine cities across Britain, Denmark, and USA, illustrate city branding decisions are typically made autocratically by a few public officials and private parties. Instead of accounting for the needs, voices, and imagination of citizens, the decisions are typically made by private brand management agencies and political elites (Bennett and Savani, 2003). Accounts of Greenberg (2008) on New York and Brownill (1994) on London, show the opaqueness of the city branding process. They argue that city branding management takes public needs out of the equation and puts the needs of the brand image at the forefront of decision-making (Greenberg, 2008; Brownill, 1994). The recent account of Dinardi (2017) on Buenos Aires takes the critique even further in her claim that political parties and individuals have exploitatively used the city branding policy as a project of their personal branding. The branding of Buenos Aires, a+BA, meaning You Love Buenos Aires, is a political advertisement devised for Mauricio Macri. Dinardi (2017) points out that the practice of city branding in Buenos 
Aires has often been used for political exploitation of the Mayor and has very little reflection of the citizens of the city. The undemocratic approach to city branding practices means that administrators have imposed a single and static narrative of the city on its people (Oguztimur \& Akturan, 2015; Pasquinelli, 2013). Different groups within the city have different social expectations, and this diversity conflicts with a singular brand image the city attempts to forge (Trueman et al.,2004; Paganoni 2012). The forceful imposition of a singular identity through branding can ignore and even erase the narratives of the communities, leading to a mismatch in the brand image (Medway \& Warnaby, 2014; Paganoni 2012; Pasquinelli, 2013).

\section{Reconceptualization of City Branding}

Critical literature on city branding surveyed here can be clustered into (i) how cities are branded and (ii) why cities are being branded. This literature conceptualizes city branding as a marketing instrument to make cities economically relevant (Pasquinelli 2010; Anttiroiko 2015; Eshuis and Edwards 2013; Hansen 2010; Johansson 2012). Such conceptualization often reduces city branding to a politically docile promotional tool to gain competitiveness to attract investments, tourists and new residents. However, in more recent studies (Joo and Seo, 2018: 240; Lucarelli, 2018; Jokela 2020), city branding has been reconceptualized into a broader urban policy paradigm. This literature outlines that the recent trend of city branding involves a bottom-up participatory approach that seeks to induce a certain urban imaginaries and political narrative at the community level. In other words, city branding involves the production of a new discourse. The discourse is propagated and legitimized in the local politics through the participatory process of the brand-building, where citizens participate in "re-imagining" the city. This engineered discourse consequently forms 
the justification of policies, planning, and overall governance. Additionally, this new urban imaginaries of city branding postulates what the city aspires to be and consequently creates ideas of what citizens of the city should do. In the process, city branding plays a role in the production of "new urban subjects with desirable qualities" (Jokella 2020). Therefore, this reconceptualization of the city brand is distinctively different because it is not limited as a politically mute marketing strategy. Rather, it is as a tool of governmentality through which new discourse is produced and, subsequently, shapes policies, planning, and subject-making.

\section{Discourse and City Branding}

This section explores the relationship between political discourse and city branding. The political discourse can be defined as the language that is used in the public sphere. The indispensable relationship between discourse and politics has been long established. Discourse mediates our expression, negotiations, conflicts, consensus and in the process, shapes the communities we make, institutions we build, and policies that govern us (Kirvalidze and Samnidze 2016; Bayley 2004; Joseph 2006). As James Farr states:

"Politics, as we know it, would not only be indescribable without language, it would be impossible. Emerging nations could not declare independence, leaders instruct partisans, citizens protest war, or courts sentence criminals. Neither could we criticize, plead, promise, argue, exhort, demand, negotiate, bargain, compromise, counsel, brief, debrief, advise norconsent. To imagine politics without these actions would be to imagine no recognizable politics at all" (Farr 1989: 48).

Discourse analysts and linguists assume that our social and political actions are mediated through discourse. The structures and orders given to discourse shape our relationship with one another, our ideologies, and how we perceive the world. 
Each discursive site of a society has a range of possible language utterances, which essentially limit and govern its subjective, epistemic, and ethical production.

Discourse can grant legitimacy to a certain kind of knowledge and undermine others. In this process, discourse shapes what is truth, acceptable, right, wrong, and dangerous (Cole, 2019). In Foucauldian terms, it is the discourse that creates the social rationalities (Foucault, 2004; Deleuze, 2004). It essentially directs our thoughts, ideas, beliefs, values, identities, interactions with others, and our behavior. Language and discourse are not mere tools of expression that describe the world, but rather provide meaning and shape perspectives (Fairclough, 1985).

What is the relationship between city branding and discourse? To understand this, we must go back to what city branding is. City branding is a policy instrument that seeks to create and manage image, identity, values and expectations of the city (Oguztimur \& Akturan, 2015; Kavaratzis \& Ashworth, 2005; Pasquinelli, 2013; Schwak, 2016). However, a city does not simply forge a new identity or an image due to the adoption of a new creative logo or a slogan (Kavaratzis \& Ashworth, 2009). Scholars such as Braun (2011) and Freire (2005) argues that individuals develop their own image of the city independently - 'organically'. Each individual has a personal image of the city as they navigate the city across time and space (Castillo-Villar, 2018). This 'organic' nature of the city image means that a city brand cannot simply be developed through only adoption of slogans and logos. Rather it is produced in conjunction with the city dwellers, who in their act of dwelling, voicing, imagining, and consuming the city. make the image of the city (Green, Debra, \& Perkins, 2016). Thus, building and managing a brand image of a city is inherently political- a brand is produced through multi-lateral politicking through which a city identity is negotiated, formed, and maintained (Hansen, 2010). This politicking to produce and maintain a 
brand involves manufacturing a political discourse of the image or the identity of the city.

This engineered discourse arguably permeates and entangles itself in the broader political narrative of the city. As discussed above, discourse shapes the politics of the society by forming an ideology (Foucault, 2004). It shapes social truths, rationalities, what acceptable and what is illegitimate (Cole, 2019). On a similar note, the discourse produced by city branding can potentially deploy or influence social rationalities that can structure thoughts, ideas, beliefs, values, and identities. It can shape the meaning of what the city stands for and influence its policies, planning, contestation, and negotiations. Seeing from this perspective, city branding can be argued to be more than a communication tool. Rather it has the potential to influence the political fabric of the city.

Scholars of social psychology (such as Castro 2012; Castro and Batel 2008) offer a four-step model on how newly engineered discourse is accepted ${ }^{11}$. In the first stage, a newly manufactured discourse (produced by a city brand) is nurtured and used by various social actors. However, this new discourse may not yield any institutional measures. It is only after a certain level of social consensus and legitimacy that the discourse moves to the next stage (discourse of the city brand is accepted as a political logic). In this stage, the discourse is translated into legal, policy, and institutional framework (how the discourse of a city brand influence policy, administration, and governance). This translation from an idea to an institutional framework is a messy process and is constituted in relation to its politics. Once instituted, the discourse moves to the stage of "generalization" - when the

\footnotetext{
${ }^{11}$ Although this model is conceptualized for ideas of sustainability, the model can be generalized for new production of discourse (including that of city branding).
} 
discourse is generalized as a form of discursive practice. This stage, too, is a messy political process where the discourse is contested with alternative ideas. The fourth stage, "stabilization", occurs when the discourse is fully legitimized as a social truth leading to social internalization of its ideas.

This perspective of city branding is applied in Chapter 3 to make the argument that Compassionate Louisville, as a brand, creates a discourse of compassion. This discourse permeates the political narrative of Louisville and is increasingly used in policy rationales, contestation, debates, and claim-making. The discourse is strategically used by various groups in Louisville, including politicians, city officials, religious organizations, activists, non-profits, and businesses. In chapter 5, this relationship of city branding and discourse is used to argue that Compassionate Louisville is a tool of governmentality. It disciplines the emotions of people through the discourse of compassion that legitimizes a certain type of social rationalities.

\section{LITERATURE REVIEW OF THE POLITICAL VIRTUE OF COMPASSION}

One of the central arguments of this dissertation is that Compassionate Louisville propagates the idea of public compassion. Therefore, this section reviews the literature of compassion as a political virtue. The objective of this review is to contextualize the narrative of compassion in Louisville and connect it with the broader rhetoric of compassion in US politics.

The etymology of compassion comes from the Latin and Greek roots of passion which means "to suffer or endure" (Barasch 2009; Armstrong 2011). Compassion, therefore, literally means to co-suffer with another (Lyles, et al., 2018). In political philosophy compassion is described as the feeling of empathetic distress that arises from witnessing the suffering of another, thereby resulting in altruistic 
action of alleviating that suffering. The underlying assumption is that the existence of human suffering is a sign that society is not operating at its best, and the sufferer does not deserve the distress. The act of compassion, therefore, is a virtuous action that comes from the belief that illegitimate suffering is morally unacceptable.

Compassion, therefore, is not limited to mute sympathy of the experience of others, rather it involves a call to action that actively seeks to change the state of the sufferer (Comte-Sponville, 2001; Lyles et al., 2018; Collins, et al., 2015; Whitebrook, 2002; Deane-Drummond, 2017; Lobb, 2015).

\section{Debates on Compassion as Political Virtue}

Scholarly debates on compassion as a political virtue are starkly polarized. On one side, compassion is argued to necessary virtue for a justice society. On the other side, the virtue of compassion is conceptualized as a biased emotion that is extended as neoliberal governance. This section presents the theoretical arguments of (a) scholars who advocate for compassion as a political virtue and (b) scholars who critique compassion. These arguments help to position the discourse of compassion with the overall political economy and identifies analytical categories for critiques of the discourse of Compassionate Louisville.

Argument for the Virtue of Compassion in Politics

Scholars such as Ulrich Beck (1986) Carol Gilligan (1982), Joan Tronto (1993), and Maureen Whitebrook (2002) argue against the rationalistic approach in politics that does not account for emotion, "Politics must not be merely rational in a democratic society, it must also be emotional" (Hirschman 1986, page 16). They argue that the virtue of compassion is an important cog that can link the individual 
with the collective. It also brings alleviation of suffering of the marginalized communities in the forefront of politics. Such linkage has the potential to offer new frameworks for engagement and political decision-making where suffering of everyone is acknowledged and alleviating the suffering is given priority. Advocates of the virtue of compassion claim that it offers possibility of an inclusive and just society. This claim is based on two arguments: compassion is an inherent "natural" human virtue that can be incorporated in politics, and compassion is an essential bridge to social justice.

\section{Compassion: an inherent virtue}

This section outlines the arguments that claims compassion is an inherent human virtue and hence, should be incorporated in public affairs. The argument draws from a wide range of literature, including religious doctrines, philosophy, and psychology, to claim that compassion has been a timeless and fundamental part of human existence (Kanov, et al., 2004; Sears, 1998; Armstrong, 1993). The premise of their argument is that since compassion is a natural human impulse, it can be leveraged to form a political system that is based on acknowledging and alleviating the suffering of society.

Despite fundamental differences in philosophy, geography and traditions, the concept of compassion has been ever-present in all major religious ethics (Kanov, et al., 2004; Sears, 1998; Wuthnow, 1991; Nussbaum, 1996). All three branches of Abrahamic religion mandate cultivation of the value of compassion (Armstrong, 1993). In Judaism, for example, "compassion" is an attribute of God and following this character of God is made compulsory (Sears, 1998). In a similar tone, Christianity puts heavy emphasis on compassion in modeling personal character; the Gospel of Mark records Jesus' saying: "Love your neighbor as yourself, there is no 
commandment greater than these." ${ }^{12}$ In Ephesians, Paul wrote, "Be kind and compassionate to one another, forgiving each other, just as in Christ God forgave you"13. Islam also places heavy importance on the notion of compassion: the second verse of the first chapter of the Quran attributes God with the name "al-Rehman alRahim" which translates into "the Compassionate, the Merciful". In Islamic traditions, the prophet Mohammad was quoted on the importance of compassion, 'The parable of the believers in their affection, mercy, and compassion for each other is that of a body; when any limb of it aches, the whole body reacts with sleeplessness and fever"14. Even beyond the Abrahamic traditions, compassion can be found in almost all religious traditions. In Confucius and Daoist traditions, compassion is regarded as one of the core virtues that must be cultivated (Chan, 2003; Culham, 2014). In fact, the famous phrase, "Do not do to others what you would not like them to do to you", came from Confucius. In Buddhist traditions, compassion for all sentient beings is compulsory, a necessary pre-requisite to achieve the Nirvana, the ultimate Buddhist goal (White, 2012). In Hinduism, one of the most prominent divine entities, Sri Krishna, is worshipped as a God of compassion. Hinduism advocates compassion for all, as part of its universal message since everyone and everything in the universe is a manifestation of God. Based on the presence of a narrative of compassion in various religious which originated in different parts of the world and history, the proponents of the virtue compassion argues that compassion is an inherent virtue of human beings.

\footnotetext{
${ }^{12}$ Mark 12:31

${ }^{13}$ Ephesians 4:32

${ }^{14}$ Sahih Muslim, Book 32, Number 62580
} 
This argument is strengthened by a blend of scholarships from evolutionary biology, psychology and neuroscience which claim that compassion is a "natural" emotion. Darwin (1878), for example, posited that when someone involuntarily observes the suffering of another, the witness tends to experience the emphatic distress too, and thereby acts to reduce the misery of others to diminish their own empathetic misery. Furthermore, according to Darwin, natural selection tends to favor the compassionate communities: species which included the higher number of compassionate individuals would flourish and have the higher offspring (Ekman, 2010; Darwin, 1878). Recent archaeological evidence and interpretation seemed to support this claim where human ancestors are found to show long-term compassionate care for others (Deane-Drummond, 2017). Take the case of the skeleton KNM-ER 1808, a female Homo-Ergaster dated around 1.5-million-years-old who suffered from a chronic reduction in bone density. Her conditions were such that she could only have survived till old age with intensive care of others- which leads Spiken et al. (2010) to believe that the Homo-Ergaster had the capacity to show compassion. Another archaeological case of long-term compassionate care is that of Shanidar 1, dating to around $60-80,000 \mathrm{BP}^{15}$, a Neanderthal who suffered injuries in his adolescence that resulted in multiple fractures with the right-side almost withered as well as blindness. However, the skeletal analysis shows that he survived till old age leading many archaeologists to believe that a system of compassionate care for the physically impaired existed in the hunter-gatherer Neanderthal community (Klein, 1999). Based on such archaeological evidence, scholars such as Deane-Drummond (2017) and Spikins et al (2010) argued that compassion might be a biological

\footnotetext{
${ }^{15}$ BP refers to Before the Present-meaning the number of years before the present
} 
response hard-wired in our brains through evolution. A branch of recent scholarship in psychology and neuroscience also seems to support this claim. They argue that cultivating compassion yields a range of benefits for individual physiological processes (Klimecki, et al., 2014; Kogan, et al., 2014), psychological processes (Keltner, et al., 2014; Jazaieri, et al., 2013) and social relationships (Cozolino, 2007; Penner, et al., 2005). In other words, when we feel cared for and also offer our compassion, our body functions more optimally (Gilbert, 2015; Cacioppo \& Patrick, 2008).

Based on these arguments, the advocates of compassion claim that compassion is a natural human virtue and therefore, its use to organize society is entirely plausible. In other words, there is a possibility of developing a political economy that is not based on the virtue of self-sufficiency, self-preservation, and self-interest, but a system based on the virtue of compassion for others. This idea is not new. Eighteenthcentury philosopher Jean-Jacques Rousseau posited that compassion is one of the core human impulses which exists even prior to reasoning, leading to his conception of 'natural right'. Rousseau argues that humans have a strong distaste in seeing the suffering of another and thus do not willingly mistreat others unless our selfpreservation is at stake. He believed that people also extend their compassion to others for a feeling of self-importance and power. However, he argues compassion is the least harmful manifestation of exertion of self-importance and power over another- rendering compassion as a desirable virtue to build a better society. According to Rousseau, a society organized with the virtue of compassion, will actively seek to alleviate the suffering of others, create solidarity, reduce the distress of inequality, and foster conditions of human flourishing. Therefore, a virtue of 
compassion should be the cornerstone of an ideal democratic society (Marks, 2007; Boyd, 2004).

\section{Compassion is a bridge to Justice}

The second argument the proponents of compassion make is that it is complementary to social justice. . It is important to note here that compassion and justice have a love-hate relationship- the compatibility of which is hotly debated (Lyles, et al., 2017). This section, however, presents the arguments that claim compassion and justice can be compatible and even complementary (Gleeson \& Kearns , 2001; Porter, 2009; Nussbaum, 2001; Whitebrook, 2002). These scholars acknowledge the danger of compassion without the sense of justice as it can lead to parochialism, inequity and paternalism (Nussbaum, 2001; Tronto 1993). However, they argue that the notion of compassion should not be in opposition to justice; it does not seek to replace justice as posited by some of its critiques. Rather, compassion is argued to be complementary or aid to justice in a democratic system as long as there is inclusive reflective awareness of the sufferings of people (Friedmann 1987; Tronto 1993). Compassion involves a complex set of judgments that are intimately connected to empathy towards the suffering of others. This leads to the attentiveness of the vulnerability of people and to the necessary acknowledgment of the presence of injustice (Nussbaum, 2001). Additionally, without a sense of compassion for the suffering of the distressed, political measures of social justice become a collection of cold, impersonal, and administrative transfers that are resented by those who finance them, and yet are regarded as inadequate by those who receive them (Robert \& Higgs, 2015). A political system mediated only by rules and not by empathy is thus argued to experience restriction and even marginalization (Collins et al., 2012; Nussbaum, 
2001). An orientation of compassion provides solidarity - creating an emphatical relationship with one another that embeds the value of equitable justice both at the institutional and personal scale (Singleton \& Mee, 2017; Lyles el al., 2017).

Arguments Against the Virtue of Compassion in Politics

The argument against the virtue of compassion claims that compassion is incompatible with the notion of justice: it is biased, displaces rights and antithetical to solidarity. Additionally, recent scholars have also attributed public compassion as an extension of the emotional governance of neoliberalism, whose ultimate objective is to perpetuate the condition of capital accumulation.

\section{Unreliability of Compassion}

This section argues that individual compassion is inherent unreliable and biased. Compassion is described as the altruistic action that seeks to alleviate the suffering of others (Comte-Sponville, 2001; Lyles et al., 2018; Collins, et al., 2015; Whitebrook, 2002; Deane-Drummond, 2017; Lobb, 2015). This means the acts of compassion require a prerequisite emphatic acknowledgment of suffering. Therefore, compassion involves an appraisal of what constitutes as suffering and whose suffering is being accounted. This brings the question of how suffering is determined and legitimized in society. Nussbaum (1996) conceptualized that determination of legitimate suffering depends on the sufficiency of the following: (i) the idea that suffering is not trivial; that the magnitude of distress causes significant pain or loss; (ii) suffering is not self-inflicted; that is, sufferers do not deserve the pain and have no prior knowledge or means to avoid their distress. 
Despite the elegance of Nussbaum's conceptualization, this notion of legitimation of suffering is highly idealized. The reality of how suffering is legitimized is fraught with biases, shaped by politics and has changed over the course of history (Morris, 1991; Singleton \& Mee, 2017; Schmitt \& Clark, 2006; Clark, 1987). For example, the idea of suffering in the pre-modern western culture draws from the evangelical Christianity view that suffering is natural, a part of God's punishment for sin, and a redemptive religious opportunity to imitate the suffering of Jesus Christ (Halttunen 1995). Since the eighteenth century, however, modernity has changed the perspective of suffering from being a natural order to being unacceptable and eradicable (Amato 1994). However, despite the change in perception, acknowledgment of suffering remains highly prejudiced. Our acknowledgment for suffering is often selectively extended to certain groups and ignores or even legitimizes others' suffering. In fact, our conception of suffering or distress of others depends on our commonality in race, culture, beliefs, and values (Burack 2009; Arendt 1977). There are historical examples of the biases in the conception of suffering- the colonial Europeans were often ignorant and, to an extent, rationalized the suffering of their colonized community. Similarly, slave owners in the US were blind to the suffering of the slaves being owned like cattle, even during the phase when US politics was subsumed on ideas of institutionalizing universal freedom (Burack, 2009). Furthermore, Arendt (1977) argues that the sentiment of compassion is not only directed towards the suffering of others but also towards self. Through her research on moral actors who administered the machinery of the Third Reich's mass extermination of European Jews, Arendt claims that Nazis who conducted the Holocaust were not devoid of conscience. Rather they had inverted their moral response of suffering where the object of distress were not the victims of the murders 
but their own selves: "...instead of saying: What horrible things I did to people!, the murderers would be able to say: What horrible things I had to watch in the pursuance of my duties, how heavily the task weighed on my shoulders!" $(1977,106)$. These examples show that notions of suffering and compassion are not necessarily universal. They have changed over history and culture. More importantly, the examples point that the conception of suffering and compassion tends to be biased. They are highly prejudiced political emotions and depends on the normative ethical position of individuals.

Such flexible judgment of suffering and vis-à-vis acts of compassion arises from the existing power structure that produces an individual's viewpoint of their world. Thus, passing the responsibility of social justice into the hands of individual compassion runs the risks of addressing social problems that only conform to individuals' ontological bias and ignore the suffering that does not follow their perspective. In simpler words, the compassion giver chooses to act in a way that they construct as compassionate, to the sufferer they deem to be suffering, ignoring all other distress that may exist in the community that does not conform to their worldview. Since compassion can be usually provided by resourceful and wealthy individuals, this flexibility of social construction of suffering and compassion means that the legitimization is controlled by the elites (Burack 2009; Arendt 1977).

\section{Incompatibility with Justice}

Philosophical arguments of the conflict of compassion and justice can be categorized into three themes. First, compassion is critiqued for being discriminating and biased-it is a highly selective emotion that is mediated by the existing politics and culture (Collins, et al., 2012; Whitebrook, 2002). We tend to show compassion when we acknowledge the suffering of another. Arendt (1963), however, argues that 
our acknowledgment for suffering may be selectively extended to certain groups and ignore or even legitimize the suffering of others. In other words, whose suffering is legitimized and who deserves compassion is fraught with biases based on our commonality in race, culture, beliefs or values (Morris, 1991; Singleton \& Mee, 2017; Schmitt \& Clark, 2006; Clark, 1987).

Second, compassion is argued to be inconsistent with rights. The notion of rights is conceived as enforceable; right-holders are sovereign people who can make a legal and moral claim based on their rights (Hart, 1982; Mill, 1859, Stanford Encylopedia of Philosophy, 2020). In other words, rights are something that can be demanded. Compassion, on the other hand, is voluntary by nature. We cannot legally or morally hold individuals to be kind to one another, to give charity, or to altruistically alleviate the sufferings of others. In other words, compassion can never be demanded. This voluntary nature of compassion in politics entails that people who are in distress are not ensured alleviation of their suffering. Rather they are dependent on the benevolence of the privileged who may or may not extend their kindness (Marks, 2007; Kaika, 2017; Nussbaum,1996; Berlant, 2004; Singleton \& Mee, 2017).

Third, compassion is argued to be a divisive practice- where sufferers are transformed into an object that needs help (Kaika, 2017). It divides people into groups of powerful and weak, where through the act of compassion the powerful bestow kindness and generosity on the weak. Such divisive practices lead to the entrenchment of social segregation. It is a social privilege over the sufferer from whom the privileged have a comfortable distance. People who are suffering, vis-à-vis the poor, the marginalized and oppressed, are being treated as voiceless victims of a preventable evil who can be saved by a wealthy philanthropist. Compassion in public 
affairs, therefore, is itself a form of injustice (Eikenberry \& Mirabell, 2018; Berlant 2004).

\section{Political Virtue of Compassion as Emotional Governance}

Another critique found in the literature connects compassion in politics with Foucault's notion of Governmentality (A more detailed review is provided in Chapter 5 and thus kept brief here). This literature argues that compassion is a form of humanitarian governance that is connected to the emergence of neoliberalism (Haskell 1985). The premise of the argument is that a certain set of emotional configurations is required for the perpetuation of neoliberalism. Emotions play a central role in meaning- the making of we are, what we should do, what is legitimate and what is unacceptable. Specific emotional configurations produce specific materiality, experiences, and social normality (Kiersey, 2014; D'Aoust, 2014; Vrasti \& Montison, 2014). Conceived in this way, certain settings of emotions are required for a specific social order to be sustained. In other words, the development of certain specific emotions is integral for a social order such as neoliberalism to function and be acceptable. Management of emotions, therefore, becomes an object of neoliberal governance, guiding individuals to experience certain emotions that are 'productive' while inhibiting emotions that are threatening to circuits of productions (Pedwell, 2014; Clough, 2007; Clough, 2008; Anderson, 2012; Hardt, 1999; Ahmed, 2010; Yun, 2010; Schuller, 2018; Gil, 2016; Rutland, 2015; D'Aoust, 2013; Lobb, 2015; Dawney, 2013).

The narrative of compassion in politics, according to this literature, is deployed as a governmental tool whose motive is to have efficient state control of the population through disciplining emotion of the people. It serves the role of managing 
the configuration of emotions of individuals to induct certain social competencies required for the circuit of capitalism and reproduction of neoliberal order. It is also a tool to expand state control over the marginalized and disfranchised. It does so by deploying a new logic of inclusion/exclusion where care is deployed according to the rationality of 'legitimate' suffering. Simultaneously, it maneuvers the emotions of the people through depoliticizing the causes of their suffering. It focuses on the need of the present only, without taking accountability for the historical violence, domination, and deprivation that induces the conditions of the present suffering. This leads to denying the marginalized group the right to justice and yet maintaining the status quo of the power structure of accumulation. In other words, a humanitarian approach is a form of neoliberal governmentality that entails an expansion of state power to govern and discipline more bodies (Fassin, 2012; Haskell 1985; Poovey 1995; Clark 1997; Reid, 2011; Mavelli, 2017; Ticktin, 2011; Walters, 2010).

\section{Compassion in US Politics}

Although virtues such as justice, mercy, self-sufficiency, and forgiveness receive more attention, scholars such as (Hackworth 2012; McCarthy 1990; Naples 1992; Collins, et al., 2015, Bean, 2014, Stoesz, 2002) have argued that the narrative of compassion also plays a part in "undergirding policies in more subtle way" and has a long history in US politics. The narrative of compassion in US politics is often subsumed in the broader discourses of poverty, immigration, marginalization, gender and racial issues (McCarthy 1990; Naples 1992). For example, commentators such as Bennett (1993) have argued that virtue of compassion may have inspired early US immigration policy in the nineteen century: "Lazarus's poem [The New Colossus], 
like the Statue of Liberty, came to popularize America's mission as a refuge for immigrants. Here is compassion as a national policy, one of America's great national policies" (p. 179). Similarly, according to Stryker \& Wald (2009), the supporters of the federal welfare programs in the mid-twentieth century have used the narrative of compassion in policy debates with a general position for compassionate accountability of the government to alleviate the social sufferings. In recent times, the political debates in the Violence Against Women Act of 1994, the Stafford Act, and the Personal Responsibility, and Work Opportunity Reconciliation Act were subsumed with the rhetoric of compassion (Collins, et al., 2015, Bean, 2014, Stoesz, 2002).

Compassion in the political rhetoric of the US has roots in the Christian belief of 'Love Thy Neighbor' and liberal ideology (Hackworth 2012). This narrative of compassion that infused Christian beliefs and liberalism was perhaps first popularized by the US folk hero and republican congressman Davy Crockett in the 19th century when he famously declined a bill that sought to appropriate $\$ 100,000$ to the widow of a distinguished naval officer. He argued in the House:

"We have the right, as individuals, to give away as much of our own money as we please in charity; but as members of Congress we have no right to so appropriate a dollar of the public money. ... I am the poorest man on this floor. I cannot vote for this bill, but I will give one week's pay to the object, and if every member of Congress will do the same, it will amount to more than the bill asks" (Ellis, 1884, p 139).

This entails that every individual has a moral obligation to look after their neighbor based on the Christian doctrine of helping one another. However, it is also emphasized that such compassionate acts are strictly an individual response, a private affair, and should not be a public affair pertaining to government.

Hackworth (2012) pointed to the relationship of (neo)liberalism and evangelical Christian values in the US. On one side, evangelical Christians tend to 
advocate for liberalism, calling for smaller government. On the other side, they harbor Christian values of compassion and helping the poor. This makes anti-welfare politics particularly challenging because it ignores the plight of the marginalized communities. This dilemma is often resolved by a hybrid ideology that fuses liberalism and narrative of compassion, which is now known as "Compassionate Conservatism." The idea of Compassionate Conservatism has deep roots in Evangelical Christian thoughts, stemming from the works of theologians such as Richard Neuhaus (1977) and Michael Novak (1980), who proposed to reinforce religious institutions to mediate social issues (Olasky, 2000). The premise is the belief that many social ills that plague the US are a result of the dominance of 'megastructures' such as large government: the big bureaucracy does not have the flexibility and scope to attend to the diverse forms of suffering individuals experience. Rather, Compassionate Conservatism postulate that ground-level social institutions, especially the religious institutions and non-profits organizations, are better suited to alleviate the suffering of people: "shift power away from the bureaucracy to the people in the compassionate community, who actually deal with these problems" (Olasky, 2000, p. 13). The role of the government, according to Compassionate Conservatism, is not to provide welfare to alleviate suffering but to support civil society and religious actors to perform the frontline work of addressing social issues (Olasky, 2000; Pilbeam, 2003; Collins, Garlington and Cooney 2015). In other words, Compassionate Conservatism is another form (neo)liberalism. It calls for less accountability of the government for the suffering of the people and smaller government welfare programs. It places responsibility on individuals and nongovernmental institutions for solving social problems (Vitellone, 2011; Woodward, 2004). The compassionate conservatism has been popularized through George W. 
Bush's presidential campaign. The Bush administration justified a $\$ 24$ billion project to subsidize faith-based social services through the reasoning of Compassionate Conservatism (Stoesz, 2002; Stryker \& Wald, 2009).The literature of compassion in US politics at the urban scale can be argued to be very limited. There is a small branch of planning literature such as Lyles et al. (2018), Gregory (2015), Collins et al. (2012), and Porter et al. (2012), which have advocated for having a compassionate approach to planning cities. The general argument of these scholars is that the increasing diversity of cities calls for an empathetic view of the suffering of different groups that can complement social justice, and aid in cultivation of shared values across diverse communities. These scholars contend that the virtue of compassion can be instilled through (a) developing reflective awareness of suffering of others, (b) exposing people to suffering of others through physical proximity, and (c) creating opportunities to act on it.

However, scholarship on the use of the narrative of compassion in US urban politics and how that shapes cities is even smaller. Murphy (2009) studies San Francisco's use of the narrative of compassion in 2004 in response to the homeless population management. She claims that the narrative of compassion reconceptualized homeless people in San Francisco from being criminals to people who deserve assistance (Murphy, 2009). Recently, Ruez \& Parekh (2019) studied "Compassionate Louisville" and claims that the use of the narrative of compassion in Louisville is political. They argue that the narrative of compassion in Louisville can be best understood in relation to the politics: specifically, how and why the rhetoric of compassion is frequently evoked in the public debate by both politicians and activists. 


\section{CONCLUSION}

The literature surveyed in this chapter, that of City Branding and political virtue of compassion, are generally disparate and, up to this point, has few lines of connection. The literature of city branding typically takes branding as a policy instrument to gain competitiveness. (Hernandez \& Lopez 2011; Kavaratzis 2009; Zenker 2009; Zenker \& Martin 2011; Eshuis \& Edwards 2013; Hansen 2010; Johansson 2012). However, recent scholarship (Joo and Seo, 2018: 240; Lucarelli, 2018; Jokela 2020) argue that city branding is more than a marketing tool. The engineering of an image produces a discourse of the identity of the city. This perceived identity can influence policy-making, administration, and overall politics. In other words, city branding is reconceptualized to more than a politically mute marketing tactic; instead, it is a process of manufacturing political discourse of the identity/image of the city, which consequently effects politics. Such reconceptualization of city branding is fairly a new concept, and currently, there are limited scholarships that investigate city branding's potential to create political discourse and, consequently, shape politics. This dissertation fills that gap (in Chapter 3) by showing that Compassionate Louisville generates a discourse of certain image/identity of the city. This manufactured discourse permeates Louisville's political narrative and is increasingly used in policy rationales, contestation, debates, and claim-making. The discourse is strategically used by various groups in Louisville, including politicians, city officials, religious organizations, activists, non-profits, and businesses.

The scholarly debates on the virtue of compassion in politics, presented in this chapter, open several analytical categories to critique the discourse of compassion in Louisville. First, the discourse of compassion in US politics comes from the legacy of amalgamation of (neo)liberalism and theology that calls for the deployment of social 
welfare not through government but through private actors. In other words, it moralizes the neoliberal ideological framework that privatizes welfare provision and distributive justice. This point helps to contextualize the Compassionate Louisville brand as a neoliberal project and forms the overarching critique of this dissertation.

Second, the virtue of compassion is conflicting with the notion of justice. Compassion is critiqued to be biased, as it often extended based on commonality in race, culture, beliefs or values. This essentially creates an incongruency with the notion of justice. Compassion is also argued to displace rights. The unenforceability of public compassion entails that the suffering of an individual is alleviated not based on the rights of the individual, but rather because of the benevolence of the privileged. In this perspective, the right to the alleviation of suffering is displaced and transformed into private benevolence of the privileged (Morris, 1991; Singleton \& Mee, 2017; Schmitt \& Clark, 2006; Clark, 1987). Additionally, compassion is argued to be a divisive practice- where sufferers are transformed into an object that needs help. Such divisive practices lead to entrenchment of social segregation (Kaika, 2017, Eikenberry \& Mirabell, 2018; Berlant 2004). These analytical categories are used in Chapter 4 to critique the discourse of compassion in Louisville to make the claim that it does not and cannot address the social problems of the city.

Third, the literature review presents the idea that the virtue of compassion is deployed as neoliberal governmental technology to discipline the emotion of the people. Through the discourse of compassion, people are guided to feel emotions in certain ways in order to achieve required capital production and perpetuate ideologies (Clough, 2007; Anderson, 2012; Ahmed, 2010; Yun, 2010; Schuller, 2018; Gil, 2016; Rutland, 2015). This perspective is used in Chapter 5 to argue that the brand of Compassionate Louisville, behind its veil of humanitarianism, works the work of 
capital. It is an extension of neoliberal governmentality that seeks to discipline the emotion of people to increase productivity and extract more wealth. 


\section{CHAPTER 3 - THE BRAND OF COMPASSIONATE LOUISVILLE}

\section{INTRODUCTION}

In order to understand what "Compassionate Louisville" does, it must be first be explained what "Compassionate Louisville" is. In this regard, the chapter first positions "Compassionate Louisville" as a city brand. It argues that Compassionate Louisville is not a city-funded program or a department; it does not have any material goals, measurable targets, or a single line of budget allocation. It is neither a measure of an individual benevolence of the city nor does it involve an institutional approach of having specific policies to address suffering. Instead, "Compassionate Louisville" can be best described as an image engineering - what the branding scholars refer to as city branding.

What does the brand of Compassionate Louisville do? Does it have any influence on city politics? Quite often, city branding is theorized as a policy instrument of an entrepreneurial urban governance approach to make cities economically relevant to attract capital, tourists and new residents (Pasquinelli, 2010; Anttiroiko, 2015; Eshuis and Edwards, 2013; Johansson, 2012). Such conceptualization of city branding views it as a transient marketing strategy or boosterism policy that reduces branding to logos and slogans (Anholt, 2005; Kavaratzis \& Ashworth, 2005). This chapter, however, argues that Compassionate Louisville cannot be conceptualized only as a selling tactic targeting the external 
market. Instead, the brand of Compassionate Louisville also has a degree of influence in local politics through the discourse it produces.

The branding efforts of Compassionate Louisville produce a discourse of "compassion" that propagates the idea that acts of individual benevolence are honorable, apolitical, and moral. It also positions individual acts of compassion as a solution to the chronic social problems of the city. The chapter argues that this discourse of compassion is increasingly becoming a political logic of claims, contestations, policy rationale, and everyday politics. It is strategically used by various social actors in Louisville, including politicians, city officials, religious organizations, activists, non-profits, and businesses.

To support this argument, the chapter provides an extensive list of cases where the discourse of compassion has been used in both formal city political debates and informal politics of claim-making. It shows that the logic of compassion is increasingly being used in negotiating a wide range of political issues such as fiscal policy, minimum wage, public safety, and neighborhood development. The discourse is used as a logic to frame long-term strategic city plans, departmental objectives, ordinances, and policies. Additionally, the discourse of compassion is actively used by citizens to make political claims in a wide range of issues such as LGBTQ rights, racial justice, homelessness, immigrant rights movement, and abortion rights activism. These cases show that the logic of compassion has been used in conjunction with the traditional narratives of freedom, right, and justice to frame political position.

These examples demonstrate that the Compassionate Louisville brand is not a politically mute marketing tool. Instead, the use of the language of compassion by various social actors to make political positions shows the potency of the discourse produced by the brand. It effectively establishes a new political logic in Louisville 
through which political debates are mediated, negotiated, contested, and accepted. The Compassionate Louisville brand, therefore, is a potent political agent that has a degree of influence in planning, policies, political struggles, and overall politics.

\section{THE BRAND OF COMPASSIONATE LOUISVILLE}

In the inaugural speech after winning the election as the Mayor of Louisville in 2010, Greg Fischer announced three guiding principles of his administration: commitments to lifelong learning, health, and compassion. In the address, he said: "Compassion means everyone has a chance to succeed, to realize their potential. No matter their background, their color, their orientation, or their nationality, we are all the same in the eyes of our Creator" (Louisville Future, 2016) ${ }^{16}$. This guiding principle of Fischer's administration laid the foundation of "Compassionate Louisville". Interestingly, it coincided with the popularity of the International Compassionate City Campaign of the Charter of Compassion. In November 2011, Louisville Metro Council passed a resolution ${ }^{17}$ to publicly affirm to the Charter and declared itself the "Compassionate Hearty of America." The city administration claims "Compassion" to be a vision of the Louisville:

"This is the shared purpose and principle. Compassion is common ground and a unifying force in our polarized world. Compassion impels us to work tirelessly to alleviate the suffering of our fellow creatures, to dethrone ourselves from the center of our world and put another there, and to honor the inviolable sanctity of every single human being, treating everybody, without exception, with absolute justice, equity and respect. Compassion is the bridge

\footnotetext{
16 "A conversation with Mayor Fischer about compassion", Louisville Future, Novermber 24, 2016, Retrieved from: https://louisvillefuture.com/archived-news/compassionate-city/.

${ }^{17}$ The Resolution is attached in Appendix B
} 
between internal practice and external change" Louisville-Jefferson County Metro Government n.d.) ${ }^{18}$.

Up until $2019^{19}$, the approach of the city administration has been to lend the narrative of compassion to various initiatives of non-profit and faith-based organizations. For example, the city government terms the Metro United Way's annual event, Mayor's Give a Day Week, as a signature "Compassionate Louisville event." The initiative provides a platform for residents of the city to volunteer in social projects (Metro United Way, 2019) ${ }^{20}$. Another initiative that the city administration claims to be part of the Compassionate Louisville is the Compassionate Schools Project. This project is actually a partnership between the University of Virginia and the Jefferson County Public School system, and financed through private grants. It seeks to understand the impact of mindfulness when taught in the curriculum of elementary or secondary schools on student's academic performance and behavior.

It is important to note here that these projects are not city-funded initiatives. The city government of Louisville does not have a direct stake in these projects. Louisville does not have any city-funded department, programs, or project that is responsible for the compassionate initiatives. In fact, there is not a single line of the fiscal budget allocated to Compassionate Louisville. In other words, there are no

\footnotetext{
18 “Compassionate Cities Mission Statement”, Louisville-Jefferson County Metro Government, accessed May 20, 2020, retrieved from: https://louisvilleky.gov/government/compassionatecity/compassionate-cities-mission-statement.

${ }^{19}$ On November 7 2019, the Mayor announced a formation of a new 501c3 called Compassionate Louisville. The relationship of this new non-profit organization with the city administration is still not clear. The organization is yet to announce any activities.

20 “Mayor's Give A Day Week of Service”, Metro United Way, 2019, accessed May 20, 2020. retrieved from: https://metrounitedway.org/give-a-day-mayors-week-of-service/.
} 
concrete city-funded programs, departments, or employees that materialize the value of compassion in Louisville. Instead, the narrative of "compassion" is strategically extended to such projects to leverage the reputation of the city of being "compassionate." It forms a symbiotic relationship between the city and these projects that lend each other their goodwill to garner a favorable reputation.

Because of the lack of material presence, this dissertation describes "Compassionate Louisville" as a public imagery. It is a strategy to manufacture an image of what the city wants its identity to become to its residents and to its external stakeholders. It produces an image and reputation of being empathetic, benevolent, and moral. In other words, Compassionate Louisville can be conceptualized as a city brand.

City Branding comes from an entrepreneurial governance approach that commodifies the city to market to investors, tourists, and new residents (Eshuis \& Edwards, 2013). In the case of Louisville, there are indications that the brand of Compassionate City serves this role. For example, Ruez \& Parekh (2018), in their research on the politics of compassion in Louisville, have found that investment is considered one of the success parameters of the compassionate initiatives, indicating the entrepreneurial aspect of the compassionate city. Mayor Fischer has claimed multiple times that compassion is good for business (Marketplace, 2017) ${ }^{21}$. He claims that compassion is one of the points of attraction for investment in Louisville: "Our focus on compassion is something that resonates worldwide and is so relevant in today's world . . . And I always welcome the chance to tell our city's story to potential investors and business interests that may be looking to expand in the U.S" (Elahi,

\footnotetext{
21 "Can compassion have economic benefits?" Marketplace, August 29, 2017, Retrieved from: https://www.marketplace.org/2017/08/29/can-compassion-have-economic-benefits/.
} 
$2018)^{22}$. In a similar vein, in the budget announcement speech of 2017, the Mayor claimed: "And compassion has helped us in many ways. It builds our social muscles as part of our global brand, and as you have heard me say, Computer Share chose Louisville in part because of our city's emphasis on compassion. So compassion is good for business" (Louisville Metro Council Meeting Minute, see Appendix H for transcript).

Additionally, the narrative of compassion is heavily used to create a favorable image to attract tourism in Louisville. The first line in the official website of the city that promotes tourism, gotolouisville.com, uses the word compassion: "Yes, Bourbon is a spirit that comes in a glass, but it's also a spirit that defines our culture and compassion, our arts and parks, our creative energy". Similarly, the international tourist information page of the website says: "Louisville: A Compassionate City. Welcome to Louisville - a city touted around the globe for its compassion" (Go to Louisville n.d.) ${ }^{23}$. The 2017 city marketing plan (Louisville Convention \& Visitor Bureau 2017) and the 2018 branding guideline report (Louisville Convention \& Visitor Bureau 2018) explicitly mention the strategy of promoting the narrative of compassion to portray a welcoming, friendly and inclusive city to national and international tourists. A part of these plans was materialized through renaming the Louisville airport as Muhammad Ali International Airport. Donald Lassere, the President and CEO of the Muhammad Ali Center stated in the renaming ceremony: "The renaming of the airport communicates to the world that Muhammad Ali's

\footnotetext{
${ }^{22}$ Amina Elahi, "In India, Fischer's Message Of Compassion Could Have Economic Benefits." WFPL, February 16, 2018, retrieved from: https:/wfpl.org/in-india-fischer-message-of-compassion-couldhave-economic-benefits/

23 “International Welcome," Go To Louisville, accessed May 20, 2020, retrieved from: https://www.gotolouisville.com/travel-tools/international-welcome/.
} 
hometown is bold in its thinking, along with being a city of greatness and compassion"(Williams 2019) ${ }^{24}$. Recently, Louisville Tourism ran a social media campaign on its official Twitter account stating that Louisville is lighting up some of its tourist attraction with green lights to "symbolize compassion for the all the COVID-19 victims"25. The picture below shows a snapshot of the Twitter promotional campaigns.

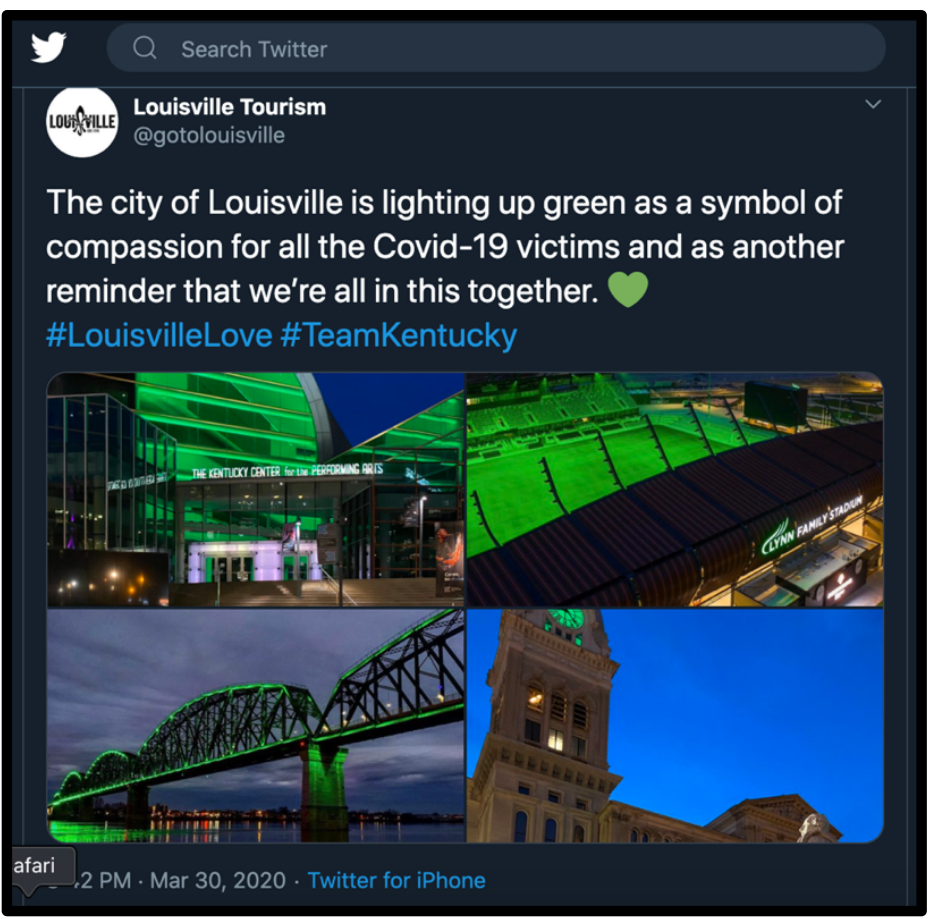

Figure 1: Snapshot of the Twitter promotional campaign ran by Louisville Tourism

These indicate that the "Compassionate Louisville" brand is indeed a selling proposition by creating an attractive image to draw investments and tourists. However, this chapter argues that seeing the brand of Compassion Louisville only as

\footnotetext{
${ }^{24}$ Bethanni Williams, "Ali Week includes marking new branding, name of Louisville Airport." WHAS11, June 6, 2019, retrieved from: https://www.whas11.com/article/news/local/ali-weekincludes-marking-new-branding-name-of-louisville-aiport/417-0c04015a-7791-4a62-85c0$\mathrm{c} 2 \mathrm{c} 47 \mathrm{c} 148 \mathrm{fdb}$.

${ }^{25}$ Link to the tweet: https://twitter.com/gotolouisville/status/1244787065805574147?s=20
} 
a selling tactic with no effect on local politics might be a narrow perspective. It argues that the image of Compassionate Louisville is not produced in a political vacuum, and hence, it cannot be reduced to politically mute slogans and rhetorics. Instead, the chapter argues that Compassionate Louisville has a deeper influence in local politics. It does so by producing a discourse of compassion that mediates policies, planning, contestation, and negotiations.

\section{THE DISCOURSE OF COMPASSIONATE LOUISVILLE}

City branding involves creating a collective expectation, positioning that expectation, and meeting that expectation (Ashworth and Voogd 1995; Kavaratzis 2015). Cities carry affective meaning in the minds of their residents (Greenop \& Darchen, 2016). A city does not simply forge a new identity or an image due to the adoption of a new creative logo or a slogan (Kavaratzis \& Ashworth, 2009). Rather it is produced in conjunction with the city dwellers, who in their act of dwelling, voicing, imagining, and consuming the city, makes the image of the city (Green, Debra, \& Perkins, 2016). Thus, building and managing a brand image of a city is inherently political- a brand is produced through multi-lateral politicking through which a city identity is negotiated formed and maintained (Hansen, 2010; Ooi, 2004).

As outlined in chapter 2, the production of a city brand involves manufacturing a political discourse of the city's image. Discourse, as understood in CDA method, has the potential to mediate expression, negotiations, conflicts, consensus (Kirvalidze and Samnidze 2016; Bayley 2004; Joseph 2006). The structures and orders given to discourse shape our relationship with one another, our ideologies, and how we perceive the world. It can grant legitimacy to a certain kind of knowledge and undermine others. In this process, it can shapes what is truth, 
acceptable, and illegitimate (Cole, 2019). In other words, the discourse of an image produced by a city brand can potentially create and maintain social rationalities.

What is the discourse produced by the "Compassionate Louisville" brand? The city website describes compassion as actions, "ranging from shoveling snow from the sidewalk of an elderly neighbor to helping read to a struggling student" (Louisville-Jefferson County Metro Government n.d.) ${ }^{26}$. In a nutshell, therefore, the discourse produced by the Compassion Louisville is a call of individual acts of benevolence to help one another. It deploys a logic that makes the virtue compassion as one of the fundamental requirements of morality and ethics. As quoted by an interviewee, "If you do not aspire to be compassionate, then I think you have something lacking in your humanity." In other words, the discourse of compassion pushes the idea that every moral individual should subscribe to the value of compassion. An individual who does not hold the virtue of compassion is deemed as immoral, corrupt, and unethical. Similar to the rhetoric of compassion found in the Compassionate Conservatism ${ }^{27}$, it tends to responsibilize individuals to make social changes and propagates the idea that much of the social problems that plague the city can be resolved by individual compassionate behavior.

Since Louisville declared itself "Compassionate" in 2011, the discourse of compassion has permeated the political narrative of the city. As one of the interviewees claimed: "Having elected officials talk about something on a very

\footnotetext{
26 “Louisville is a Compassionate City”, Louisville-Jefferson County Metro Government, accessed May 20, 2020, retreieved from: https://louisvilleky.gov/government/compassionate-city.

${ }^{27}$ Compassionate Conservatism is an amalgamation of Christian theology and conservativism. The term was made popular by President George W. Bush. According to Compassionate Conservatism, the role of the government is not to provide welfare to alleviate suffering but to support civil society and religious actors to perform the frontline work of addressing social issues. Please refer to Chapter 2 for a detailed explanation of Compassionate Conservatism.
} 
consistent basis adds energy and brings people to the fore." The discourse of compassion has increasingly become a new logic in the political debates. This logic of compassion is used by various social actors to make political claims, including politicians, city officials, religious organizations, activists, non-profits, and businesses. The following table outlines how the discourse of compassion has been used in various political settings in the city.

Table 2: Outline of how the discourse of compassion permeates the political narrative of Louisville

\begin{tabular}{|c|c|}
\hline $\begin{array}{l}\text { Use of the discourse of } \\
\text { compassion }\end{array}$ & Explanation \\
\hline Language of Planning & $\begin{array}{l}\text { The language of compassion is used in the vision and } \\
\text { goals of the long-term city plans that guides the } \\
\text { planning and governance of the city. } \\
\text { Additionally, the discourse is also used in the } \\
\text { mission statements of various city departments. }\end{array}$ \\
\hline $\begin{array}{l}\text { Language of political } \\
\text { justification }\end{array}$ & $\begin{array}{l}\text { The discourse of compassion is frequently used in } \\
\text { Metro Council to justify positions in various political } \\
\text { debates such as that of fiscal budget, minimum wage, } \\
\text { economic development, homelessness, affordable } \\
\text { housing, health equity, sanctuary city, animal rights, } \\
\text { parks, cannabis legalization, and coronavirus } \\
\text { response. }\end{array}$ \\
\hline Language of ordinance & $\begin{array}{l}\text { At least two ordinances have explicitly used the } \\
\text { narrative of compassion in its language: } \\
\text { - Ordinance } 216 \text {, Series } 2014 \text {, which relates to } \\
\text { minimum wage. } \\
\text { - Ordinance } 201 \text {, Series } 2017 \text {, which related to } \\
\text { police authority over illegal immigrants. }\end{array}$ \\
\hline Language of Activisms & $\begin{array}{l}\text { The discourse of compassion has been used in } \\
\text { Louisville to make political claims in the following } \\
\text { activisms: } \\
\text { - Occupy ICE: used the language of } \\
\text { compassion in the demonstration against ICE. } \\
\text { - LGBTQ movement: used compassion as the } \\
\text { language of acceptance in the society } \\
\text { - Black Lives Matter: used compassion as one } \\
\text { of the languages of protest against racial } \\
\text { police violence }\end{array}$ \\
\hline
\end{tabular}




\begin{tabular}{|c|c|}
\hline & $\begin{array}{l}\text { - Homeless camp dismantlement protests: used } \\
\text { the discourse of compassion to protest against } \\
\text { camp eviction. } \\
\text { - Abortion Right movements: both sides of the } \\
\text { activisms used the narrative of compassion to } \\
\text { legitimize their stance. }\end{array}$ \\
\hline $\begin{array}{l}\text { Language of Private } \\
\text { Interest and Business }\end{array}$ & $\begin{array}{l}\text { Various private organizations have branded itself } \\
\text { with the narrative of compassion. } \\
\text { - A legal service company has branded itself as } \\
\text { Compassionate Legal Services of Louisville } \\
\text { and Southern Indiana, Inc. } \\
\text { - The Louisville Bar Association declared itself } \\
\text { as "Compassionate Organization" in 2015/ } \\
\text { - The gym Yoga Louisville promotes } \\
\text { themselves claiming that yoga helps to } \\
\text { cultivate compassionate behavior. } \\
\text { - The restaurant Roots has branded with the } \\
\text { claim that they provide "mindful, } \\
\text { compassionate cooking." }\end{array}$ \\
\hline $\begin{array}{l}\text { Language of Religious } \\
\text { Appeal }\end{array}$ & $\begin{array}{l}\text { Various faith-based organizations have used the } \\
\text { discourse of compassion for religious appeal. } \\
\text { - The Jewish Community Center of Louisville } \\
\text { associate themselves with the narrative } \\
\text { claiming that compassion is the Jewish value } \\
\text { and a way of their life (Jewish Community } \\
\text { Center of Louisville 2018). } \\
\text { - The South Louisville Community Ministries } \\
\text { claims that compassion is manifested in their } \\
\text { church: “.. where neighbors meet neighbors, } \\
\text { where families help families, where } \\
\text { compassion is manifested.” } \\
\text { Buddhist organizations Kentucky Meditation } \\
\text { Compassionate Peace Center in Louisville } \\
\text { and the Drepung Gomang Center for } \\
\text { Engaging Compassion have branded } \\
\text { themselves with the narrative of compassion. } \\
\text { The Louisville Islamic Center renamed itself } \\
\text { as the Louisville Islamic Center of } \\
\text { Compassion in 2017. }\end{array}$ \\
\hline Language of reconciliation & $\begin{array}{l}\text { The narrative of compassion is used to reconcile with } \\
\text { aggrieved protestors seeking justice for the murder of } \\
\text { Breonna Taylor in } 2020 \text {. }\end{array}$ \\
\hline
\end{tabular}


The following sections elaborate on the table and provide evidence that the discourse produced by the Compassionate Louisville is becoming a potent political logic in both (a) formal city political debates and (b) informal politics of claimmaking. It exemplifies how the discourse of compassion is used to mediate, negotiate, and contested in political debates in Louisville. It shows the potency of the discourse of compassion as a political logic in shaping the political narrative and, consequently, the overall politics of the city.

\section{USE OF DISCOURSE OF COMPASSION BY THE CITY GOVERNMENT}

This section outlines the use of the discourse of Compassionate Louisville in the formal political debates of Louisville to demonstrate that it is increasingly being used as a potent political logic to frame positions. Similar to the contemporary US cities, much of the political debate in Louisville is subsumed with the neoliberal discourse of job creation, economic development, and external capital attraction. However, since Louisville has been branded itself as the Compassionate City, the discourse of compassion has become another logic and gained traction in the narrative of planning, policies, and political debates of Metro Council.

Discourse of Compassion in Planning, Programs, and Departments

Ironically, the city of Louisville actively advocates to depoliticize the Compassionate City brand of Louisville. The website of the city government explicitly mentions that: "There is no political agenda. This effort exists to enable compassionate living to help the citizens of our community reap the benefits that come from living a compassionate life-which are many" (Louisville-Jefferson 
County Metro Government n.d.) ${ }^{28}$. This is ironic because Mayor Fisher himself has used the narrative of compassion in almost every public communication. The discourse of compassion has increasingly found its place in the language of city planning, policies and administration. It has been actively used in planning documents of Louisville that guide city governance and development. For example, in the longterm strategic plan of the city, compassion is one of the cornerstones of the vision of Louisville: "In 2040, Louisville Metro is a vibrant and diverse community that is connected, healthy, authentic, sustainable and equitable, with compassionate citizens ..." (Louisville-Jefferson County Metro Government 2019, p 31) ${ }^{29}$. The city website also declares compassion as one of the visions and values of the city. Many departments of the city government have also included the narrative of compassion in their strategic statements and goals. For example, the Department of Emergency Services states its mission is to provide "..high quality and compassionate emergency and non-emergency response ..” (Louisville-Jefferson County Metro Government n.d. $)^{30}$. The Department of Resilience and Community Services have also noted their mission as, "to fight poverty and promote compassion, stability, and the empowerment of residents and communities" (Louisville-Jefferson County Metro Government n.d.) $)^{31}$. Additionally, the narrative has been frequently used to justify various policy rationales and program development. The mayor has even claimed that

\footnotetext{
28 “Compassionate Cities Mission Statement”, Louisville-Jefferson County Metro Government.

${ }^{29}$ Louisville-Jefferson County Metro Government, Plan 2040: A Comprehensive Plan for Louisville Metro

30 “Emergency Services - Our Mission”, Louisville-Jefferson County Metro Government, accessed May 20, 2020, retrieved from: https://louisvilleky.gov/government/emergency-services/about-us.

31 “Resilience and Community Services Overview," Louisville-Jefferson County Metro Government, accessed May 20, 2020, retrieved from: https://louisvilleky.gov/government/resilience-andcommunity-services/about-us.
} 
compassion is one of the determinant factors in making in city investment decisions, “while it doesn't have a line item in this budget, compassion informs the decisions behind each of the investments we make for our citizens" (Louisville-Jefferson County Metro Government 2017) ${ }^{32}$.

The narrative of compassion is also evoked by city officials to call for solidarity, calm protests and create justifications. For example, during the Black Lives Matter protests for the murder of Breonna Taylor by Louisville Metro Police Department the city government's press release stated:

"We must continue to press for justice and fairness through leadership and compassion. As we move toward justice for Breonna, let us work to be part of the solution and needed change. Breonna lived to save lives, so surely, she would not want further violence to be associated with our call for justice" (Louisville-Jefferson County Metro Government 2020) ${ }^{33}$.

\section{Discourse of Compassion in Political Debates of Metro Council}

The discourse of compassion has been increasingly used in debates of the Metro Council of Louisville to argue and justify various political positions. The archived transcription of the debates of the Metro Council shows that compassion is increasingly being as political logic ${ }^{34}$. The discourse is frequently evoked in Metro Council in various debates, including fiscal budget allocations, minimum wage, economic development, homelessness, affordable housing, health equity, sanctuary

\footnotetext{
32 "Mayor Fischer's remarks for the 2017-18 proposed budget", Louisville-Jefferson County Metro Government, April 27, 2017, accessed May 20, 2020, retrieved from: https://louisvilleky.gov/news/mayor-fischers-remarks-2017-18-proposed-budget.

33 "The Louisville Metro Council releases statement concerning last night protests and violence surrounding the death of Breonna Taylor," Louisville-Jefferson County Metro Government, May 29, 2020, accessed June 20, 2020, retrieved from: https://louisvilleky.gov/news/louisville-metro-councilreleases-statement-concerning-last-night-protests-and-violence.

${ }^{34}$ See Appendix $\mathrm{H}$ for the transcript of meeting minutes of Metro Council from November 2011 to March 2020
} 
city, animal rights, park development, cannabis legalization, and coronavirus response. For example, the council member Nancy Robert debated on LLEP (lowest law enforcement priority) ordinance by urging: "I am asking you to continue leading Louisville to become the most compassionate and progressive city in the south by introducing and passing the LLEP cannabis ordinance.... This sends a message of compassion to the thousands of medical consumers in our city and to their family." In the debate on making Louisville a sanctuary city, the council member Debra Mumford claimed: “..sanctuary cities are compassionate cities, therefore it only makes sense that our city which has declared itself to be the compassionate heart of America, should also commit to becoming a sanctuary city." Even during the discussion of the response to COVID-19 pandemic, the President Pro Tem Markus Winkler claimed in the council, 'every day we see new acts of compassion and kindness to help those in need, whether it's creating a website to match vulnerable seniors with healthy individuals, neighbors helping neighbors by watching children so a parent can go to work, people donating time and money to organizations trying to meet the tsunami of needs'.

The discourse of compassion has also been central to the debate of the fiscal budget cut of 2019. In previous city budget cuts debates (before the branding of Compassionate Louisville), arguments were generally made with the logic of efficiency. For example, in 2008 the then-Mayor Jerry Abramson proposed to cut $\$ 20$ million budget, and the move was heavily debated with the logic of competency and efficiency, "Before we lay anybody off we have to ask: Are city services being delivered at maximum efficiency?" (Bailey 2008) ${ }^{35}$. However. the argument against

\footnotetext{
35 Phillip Bailey, 'Budget blues', LEO Weekly, November 26, 2008, retrieved from: https://www.leoweekly.com/2008/11/budget-blues/
} 
the budget cut of 2019 was not based on effectiveness or efficiency, but that of compassion (Velzer 2019) ${ }^{36}$. The current mayor Greg Fischer advocated for an increased tax and against a budget cut on the ground of compassion. Once the budget cut was ultimately decided by the Council, Mayor Fisher stated that he would continue to find resources to make the city compassionate- "I pledge to continue to work with the State and our Metro Council to find new revenue, and to keep fighting to make sure Louisville has the services it needs to be the thriving, compassionate city that we all deserve" (Mills 2019) 37.

The narrative has even found a place in the texts of approved ordinances. Take for example the ordinance related to the minimum wage in 2014 which says: 'Louisville has been recognized as a Compassionate City it is incumbent upon us to take legislative steps to help lift working families out of poverty, decrease income inequality, and boost our economy' (Metro Council, 2014). Or the ordinance related to police authority over illegal immigrants that says: "Louisville Metro is a city of compassion, a city that embraces our foreign-born neighbors and strives to be welcoming, hospitable and safe" (Metro Council, 2017).

These cases exemplify the growing popularity of the discourse of compassion in the formal politics of Louisville. It shows that the city brand of Compassionate Louisville is not merely a promotional tool limited to catchy slogans and fancy words. Instead, it produces a potent discourse of compassion that forms a political logic. This

\footnotetext{
${ }^{36}$ Ryan Van Velzer, 'How Louisville's Budget Reduction Affects Vulnerable Residents', WFPL, June 26, 2019, retrieved from: https://wfpl.org/how-louisvillesbudget-reduction-affects-vulnerable-residents/

${ }^{37}$ Chad Mills, 'Metro Council OKs sweeping cuts and layoffs, passing bleak budget by a huge margin' WDRB, June 29 2019, retrieved from: https://www.wdrb.com/news/metro-council-oks-sweeping-cutsand-layoffs-passing-bleak-budget/article_c031fdb2-9785-11e9-817c-a3c28c21978b.html
} 
logic of compassion is increasingly being used to mediate the formal political debates, planning, programs, and ordinances. In other words, these cases indicate the implication of the brand of Compassionate Louisville in local politics.

\section{USE OF DISCOURSE OF COMPASSION IN POLITICAL STRUGGLES}

The use of the discourse of Compassionate Louisville has not been limited to the circle of formal political debates. This section shows that the logic of compassion has been increasingly used in political claims of citizen-led activism such as Occupy Ice, LGBTQ, Black Lives Matter, Homeless Protest, and Abortion Right movements. These cases are chosen because they are national political struggles and have a presence in almost all US cities. Traditionally, these movements make arguments and demands on the grounds of rights, freedom, and justice. In Louisville, however, these political struggles have actively used the logic of compassion for their political claims.

\section{Occupy Ice Movement}

Occupy ICE is a series of protests, modeled on the Occupy Movement, that emerged in the United States in reaction to the Trump administration's harsh immigration policy with a goal of disrupting operations of U.S. Immigration and Customs Enforcement (ICE) (Levinson-Waldman and Hinkle, The Abolish ICE Movement Explained 2018) $)^{38}$. There have been Occupy ICE protests in eleven cities

\footnotetext{
${ }^{38}$ Rachel Levinson-Waldman and Haley Hinkle, 'The Abolish ICE Movement Explained', Brennan Center for Justice, July 30, 2018, retrieved from: https://www.brennancenter.org/our-work/analysisopinion/abolish-ice-movement-explained
} 
to date including that of Louisville. The political narrative behind all these protests has been the right of families to remain together, the right to work, and the right to

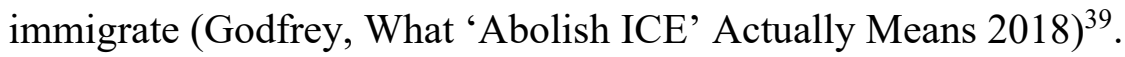

The political narrative of the Occupy ICE protest of Louisville, however, has been slightly different. In 2018, a group of about 30 activists staged a protest in front of the local office of the ICE. They set up an encampment with the aim of disrupting the activities of Louisville's ICE offices. The protest of Louisville faced the same response it faced in other cities- violently dismantled camp and detained activists. However, what is interesting and unique about this Occupy ICE protest of Louisville compared to that of the other cities has been the presence of the narrative of compassion. The Occupy ICE activists of Louisville chanted and claimed that the city could not be compassionate until it provides a safe space for immigrants despite their legal residency status. The narrative of compassion in their protest was so accentuated that they called their encampment "Camp Compassion" (Meador 2018) ${ }^{40}$. This is interesting because the usual narrative of the Occupy ICE being the right of families to remain together, right to work and right to immigrate has been infused with the discourse of compassion. Activists of Louisville Occupy ICE did not only make their claim on the basis of the rights but also because it is compassionate to make a safer place for undocumented immigrants.

\footnotetext{
39 Elaine Godfrey, 'What 'Abolish ICE' Actually Means' The Atlantic, July, 11 2018, retrieved from: https://www.theatlantic.com/politics/archive/2018/07/what-abolish-ice-actually-means/564752/

40 Jonathan Meador, “Encampment aims to “Abolish ICE,' pressure mayor.” Insider Louisville, July 2, 2018, retrieved from: https://louisvillefuture.com/archived-news/encampment-aims-to-abolish-icepressure-mayor/
} 


\section{LGBTQ Support and Activism}

The LGBTQ movements in US cities have traditionally used the discourse of civil rights, equality, freedom to choose identity and protections against discrimination (Rauch, 2019) ${ }^{41}$. In Louisville, however, the narrative of the LGBTQ activisms in support of the community has been infused with that of the narrative of compassion. For example, the non-profit organization Rainbow Advocacy which advocates for educational, cultural and social services for the LGBTQ community has used the narrative of compassion in their activism specifically in Louisville (Rainbow Advocacy 2013) ${ }^{42}$. In 2013, the pride parade of Louisville was dubbed as Colors of Compassion- actively associating itself with the Compassionate City brand. Organization/groups which lends support to the LGBT community have also bannered themselves under the reasoning of compassion. For example, the University of Louisville has set up a health-care unit for the LGBTQ community on the ground that it is "compassionate" to provide dedicated health-care service to this community (UofL Physicians 2016) ${ }^{43}$. Similarly, religious organizations such as the Cathedral of Assumption provides support and pastoral care to the LGBTQ community on the ground of compassion (Cathedral of Assumption n.d. $)^{44}$.

\footnotetext{
41 Jonathan Rauch,. "It's Time to Drop the 'LGBT' From 'LGBTQ'.” The Atlantic, January 2019, retrieved from https://www.theatlantic.com/magazine/archive/2019/01/dont-call-me-lgbtq/576388/

42 “Colors of Compassion 2013”, Rainbow Advocacy, 2013, accessed August 29, 2019, retrieved from: https://www.rainbowadvocacy.org/colors-of-compassion-2013.html.

43 "LGBTQ Care", UofL Physicians, November 21, 2016, accessed August 29, 2019, retrieved from: https://www.uoflphysicians.com/news-room/video-uofl-today-lgbtq-care.

44 “Compassion,” Cathedral of Assumption, accessed August 29, 2019, retrieved from: https://www.cathedraloftheassumption.org/parish-life/compassion/.
} 
The Black Lives Matter movement that campaigns against violence and systemic racism in the criminal justice system towards black people traditionally make their claims based on racial inequality and justice. The objective of Black Lives Matter Louisville has been consistent with that of other cities- reduction of racial violence, profiling and surveillance $\left(\right.$ Scott 2016) ${ }^{45}$. However, the movement in Louisville has strategically used the narrative of the Compassionate Louisville to take forward their agenda. The group has frequently challenged the city with the argument that Louisville cannot be compassionate until it addresses racial police violence and incarceration (Leonard 2018) ${ }^{46}$. What is interesting here is the addition of the logic of compassion in the discourse of racial activism - the idea that the Black Lives Matter is not only about the right, justice and equality, but also about compassion.

Take the case of the protest of the Black Lives Matter regarding the murder of Breonna Taylor during the Louisville Metro Police Department's no-knock search warrant raid in 2020. Protesters who marched in downtown Louisville have frequently chanted 'where is your compassion?' to the retaliating police force along with the 'Justice for Taylor'. Additionally, Sadiqa Reynolds, the president and CEO of the Louisville Urban League, in calling for justice also invoked the discourse of

\footnotetext{
45 Roxanne Scott, “Black Lives Matter-Louisville Leader On What Comes Next.” WFPL, 12 July 2016, retrieved from https://wfpl.org/what-activist-chanelle-helm-would-like-to-see-change/

46 Connie Leonard, "Protesters demand accountability after officer-involved shootings.” Wave3 News, April 26, 2018, retrieved from: https:/www.wave3.com/story/38052127/protesters-demandaccountability-after-officer-involved-shootings/
} 
compassion, "It's hard when you have been left out to believe that [Louisville] is a Compassionate City ... It's hard to feel that" (Larson, 2020) ${ }^{47}$.

\section{Homeless Protest}

Discourse to support the homeless in the USA usually reverberates on the right to survive or economic justice. Louisville, which had about 7000 homeless in 2018 (Coalition for the Homeless Louisville, 2018), adds the discourse of compassion in the equation of homeless support. The city government has been upfront about dealing with homeless issues with the narrative infused with compassion. For example, the website of the City government states: "It will take all of us in this compassionate community - government, individuals, places of faith and businesses — to make a real impact in addressing Louisville's homelessness" (LouisvilleJefferson County Metro Government n.d. $)^{48}$. On a similar note, Mayor Fisher has recently addressed homeless issues saying, "We have to help our homeless population deal with and overcome their challenges one person at a time. That's what a compassionate city does" (Spectrum News 2019) ${ }^{49}$.

\footnotetext{
${ }^{47}$ Chris Larson, "Louisville Urban League president calls for firing of officers in Taylor case." Louisville Business First, May 29, 2020.: Retrieved from: https://www.bizjournals.com/louisville/news/2020/05/29/sadiqa-reynolds-firing-lmpd-breonnataylor.html.

48 “Helping our Homeless Neighbors," Louisville-Jefferson County Metro Government, accessed May 20, 2020, retrieved from: https://louisvilleky.gov/government/resilience-and-communityservices/helping-our-homeless-neighbors.

49 Spectrum News. "Mayor Announces Funding to Help Homeless Individuals and Families." Spectrum News 1, September 6, 2019, retrieved from: https://spectrumnews1.com/ky/louisville/news/2019/09/06/fischer-announces--1-million-for-aid-tohomeless-and-families
} 
Despite the city's claim of managing homeless issues with compassion, Louisville is notorious in dismantling homeless camps, especially in winter. The protester of such camp destruction in Louisville have also used the narrative of compassion, often carrying signs that say, "Where is Your Compassion?" (Sayers \& Bailey 2017) ${ }^{50}$. The argument of the protestors has generally been that acts of dismantling homeless camps and displacing them without offering a feasible alternative solution are contradictory to the brand of Compassionate City. Orlanado Johnson, for example, who was recently evicted from a homeless camp quoted in his protest: "You say this is a Compassionate City? Then reach down and help the people" (Ratterman \& Corsey 2019) ${ }^{51}$.

\section{Pro-Life Vs Pro-Choice activism}

Perhaps the most interesting story is that of the political activism of abortion in Louisville, where both sides of the debate make their claim with the logic of compassion. The "Pro-life" activists, who campaign against abortion, traditionally make their stance on religious grounds. In Louisville, however, the pro-life activists have used the discourse of compassion to strengthen their stance: "The pro-life movement is saying this: It is good that you exist. It is good that you exist. That is the

\footnotetext{
50 Justin Sayers and Phillip M. Bailey, "Louisville helps homeless man as his camp is wiped out, but others aren't as lucky" Courier Journal, December 8, 2017, retrieved from: https://www.courierjournal.com/story/news/politics/metro-government/2017/12/08/homeless-camp-razed-downtownlouisville-compassionate-city/934026001/

${ }^{51}$ Lexie Ratterman and Gilbert Corsey, "Homeless forced to relocate as Louisville cleans out camps." WDRB, July 16, 2019, retrieved from: https://www.wdrb.com/news/homeless-forced-to-relocate-aslouisville-cleans-out-camps/article_84580a24-a7c1-11e9-ad1c-578458ff3818.html
} 
commitment of compassion" (Archdiocese of Louisville 2014) ${ }^{52}$. On the other hand, the "Pro-choice" activists in Louisville who advocate for the right to choose pregnancy and abortion, also make their political claim on the basis of the narrative of compassion. An activist of the Pro-choice movement, Dr. Ernest Marshall, puts the reasoning of his stance on compassion: "We are compassionate, loving, forgiving, understanding, nonjudgmental. Pick a side. What side would Jesus walk on?" (Platt 2017) ${ }^{53}$. This is interesting because both the pro-life and pro-choice activists, even though they are in opposition to the same debate, engage with the same narrative of compassion. This demonstrates the versatility of the discourse of compassion in making various political claims.

\section{Association with Compassion by Various Organizations}

With the increase of popularity of the discourse of compassion in the public sphere of Louisville, various organizations have started to associate themselves with the language of 'compassion'. A self-organized group of volunteers for the Charter listed 36 organizations on their website who have partnered with them, "Who Have Adopted Compassionate Organization Resolutions." This list includes a host of nonprofit organizations, religious organizations, care centers, Jefferson County Public Schools which operates 150 schools in Louisville, two neighborhood associations, a

\footnotetext{
52 "Keynote at Pro-Life Leadership Conference,"Archdiocese of Louisville, 28 July, 2014, accessed August 29, 2019, retrieved from: https://www.archlou.org/keynote-at-pro-life-leadership-conference/.

${ }^{53}$ Plam Platt, "Inside the Center of the Abortion Storm." Leo Weekly, August 23, 2017, retrieved from: https://www.leoweekly.com/2017/08/exclusive-inside-center/
} 
theater and TARC which is the public transportation provider for Louisville (Compassionate Louisville n.d. $)^{54}$.

Faith-based organizations have been at the forefront of making association with the language of compassion. The Jewish Community Center of Louisville, for example, associate themselves with the narrative claiming that compassion is the Jewish value and a way of their life (Jewish Community Center of Louisville 2018) ${ }^{55}$. Many churches in Louisville advocates for and associate themselves with the language of compassion. The South Louisville Community Ministries, for example, claims that compassion is manifested in their church: ".. where neighbors meet neighbors, where families help families, where compassion is manifested" (South Louisville Community Ministries n.d.) ${ }^{56}$. Many faith-based organizations have named or renamed themselves with the tag of 'compassion'. Several Buddhist organizations, for example, have opened in the last decade associating themselves with compassion such as the Kentucky Meditation Compassionate Peace Center in Louisville and the Drepung Gomang Center for Engaging Compassion. Both the organization offers Buddhist meditation classes with the claim that it fosters a compassionate mind and behaviors. On a similar note, the Louisville Islamic Center opted to rename itself as

\footnotetext{
54 “Partners Who Have Adopted Compassionate Organization Resolutions," Compassionate Louisville, accessed December 23, 2019, retrieved from: http://compassionatelouisville.weebly.com/partners.html. 55 “Compassion for immigrants is the Jewish way," Jewish Community Center of Louisville, January 24 2018, accessed December 23, 2019, retrieved from: https://jewishlouisville.org/compassionimmigrants-jewish-way/.

56 “Compassionate Advocacy and Emergency Assistance for Neighbors in Crisis," South Louisville Community Ministries, accessed May 20, 2020, retrieved from: https://slcm.org.
} 
the Louisville Islamic Center of Compassion in 2017 (Hassan, 2017) ${ }^{57}$. Louisville also hosts an inter-faith Muslim organization called Muslim Americans for Compassion, which seeks to "provide a platform by which Muslim Americans are able to engage their fellow citizens in such a way as to increase mutual understanding and respect through service and compassion for all" (Muslim Americans for Compassion, n.d. $)^{58}$.

However, the new-found culture of co-branding with compassion is not limited to only faith-based organizations. A legal service company, for example, has branded itself as Compassionate Legal Services of Louisville and Southern Indiana, Inc (National Immigration Legal Services Directory n.d.) ${ }^{59}$. The Louisville Bar Association declared itself as "Compassionate Organization" in 2015 (Louisville Bar Association 2015) ${ }^{60}$. A gym called Yoga Louisville promotes themselves claiming that yoga helps to cultivate compassionate behavior (Omies Yoga Studio n.d. $)^{61}$. A restaurant called Roots that has branded with the claim that they provide "mindful,

\footnotetext{
57 Riffat Hassan, "Is 'compassion' the safe word for Muslims?" Courier Journal, June 28, 2017, retrieved from: https:/www.courier-journal.com/story/opinion/contributors/2017/06/28/compassiongo-safe-word-muslims-riffat-hassan/429296001/

58 "MACUS," Muslim Americans for Compassion, accessed December 23, 2019, retrieved from: https://macus.org/who-we-are/.

59 “Compassionate Legal Services of Louisville and Southern Indiana, Inc," National Immigration Legal Services Directory, accessed November 20, 2019. Retrieved from: https://www.immigrationadvocates.org/nonprofit/legaldirectory/organization.581377Compassionate_Legal_Services_of_Louisville_and_Southern_Indiana_Inc_Louisvi.

60 “Compassionate Lawyers? You Bet!," Louisville Bar Association, 2015, accessed November 20, 2019, retrived from: https://www.loubar.org/news/article/?id=116.

61 “Welcome!", Omies Yoga Studio, accessed May 20, 2020, retrieved from: https://www.omiesyogastudio.com.
} 
compassionate cooking.... we act compassionate for our fellow creatures and for our community by choosing vegetarian ingredients" (Roots n.d.)! ${ }^{62}$

These cases demonstrate that the discourse of compassion is taken as a political logic to makes claims, arguments, and justify political positions. It indicates that the brand of Compassionate Louisville is not a mere docile slogan. Instead, it has the potency to influence the local politics. The discourse produced by the brand is entangled in the broader political narrative of the city and forms an influential political logic through which political debates are negotiated, contested, legitimized and accepted.

\section{CONCLUSION}

The objective of the dissertation is to investigate what the brand of "Compassionate Louisville" does. This chapter contributes in that endeavor by claiming that the Compassionate Louisville brand produces a discourse of compassion that influences the politics of the city. This discourse propagates the idea that acts of individual benevolence are honorable, apolitical and can solve the socio-economic issues of Louisville. The discourse of compassion is increasingly gaining popularity in Louisville and becoming a logic of political claims, contestations, policy rationale, and everyday politics. The discourse is strategically used as a political logic by politicians, city officials, religious organizations, activists, non-profits, and businesses. It reverberates in the formal political debates of Louisville, including that of fiscal policy, minimum wage, public safety, and neighborhood development. Additionally, it has been actively used by citizens to make political claims in a wide

\footnotetext{
62 "Roots: Mindful, Compassionate Cooking," Roots, accessed November 20, 2019, retrieved from: http://www.heartandsoy.net.
} 
range of issues including that of LGBTQ, racial justice, homelessness, immigrant rights, and abortion. The wide use of the discourse of compassion indicates its potency in local politics. In other words, the brand of Compassionate Louisville is not politically docile that can be reduced to a benign slogan. Instead, the brand has a degree of influence on local politics through the discourse it has produced.

It is important note here that the political economy of Louisville is still dominantly neoliberal. This chapter simply argues that the brand of Compassionate Louisville adds another logic in the mix of the existing neoliberal political narratives. The relationship of this discourse of compassion with that of the dominant neoliberalism is investigated in the following chapters ( $4 \& 5)$. These chapters argue that the discourse of compassion is not necessarily in opposition to neoliberal ideologies. Instead, the compassion is another face of neoliberalism. 


\section{CHAPTER 4 - WHAT DOES COMPASSION DO IN LOUISVILLE? A CRITIQUE OF THE DISCOURSE OF COMPASSION}

\section{INTRODUCTION}

The discourse of compassion, produced by the branding of Compassionate Louisville, calls for individual acts of benevolence. It positions itself as altruistic, honorable, and apolitical. It deploys a logic that pushes the idea that every moral individual should subscribe to the value of compassion. An individual who does not hold the virtue of compassion is deemed as immoral, corrupt, and unethical. Most importantly, the language of Compassionate Louisville propagates the idea that most social problems plaguing the city can be resolved by individual compassionate behavior; therefore, implying acts of compassion to be a solution to the social problems of the city.

This chapter critiques the discourse of compassion produced by Compassionate Louisville. It asks the question: what does this discourse of compassion do? It specifically critiques the notion that individual acts of compassion are seen as a solution to Louisville's chronic social issues. The chapter argues that compassion is not necessarily an elixir that Compassionate Louisville professes it to be. It cannot and does not address the city's social problems, such as inequality, poverty, homelessness, health disparity, and racial segregation. Instead, the discourse of compassion helps to produce and reproduce the asymmetries of Louisville in the disguise of solving them. 
This chapter is divided into four parts, each providing a critique of the discourse of compassion from a different but interrelated perspective. The first part argues that compassion in Louisville simply does not attend to the social issues of the city. Louisville is plagued with chronic social problems of inequality, poverty, homelessness, health disparity, and racial segregation. Over the decade of the presence of the brand of Compassionate Louisville, the social problems and suffering of the marginalized communities have remained the same, if not worsened. The city government has apportioned such an insignificant amount of resources to alleviate the suffering of the marginalized communities that the city's claim of being "compassionate" is questionable.

The second critique argues that the discourse of compassion is concerned less with alleviating the suffering of social problems and more with moralizing political positions that lend legitimacy, justification, and moral superiority. The discourse of compassion holds a moral loftiness in Louisville. In other words, the discourse of compassion positions itself as moral that lends political position moral legitimacy. This part argues the narrative of compassion is deployed not to alleviate the suffering of the marginalized community but as a strategy to add moral legitimacy to political positions.

The third critique of the discourse of compassion in this chapter claims that the narrative of compassion shifts the responsibility of issues of welfare provision, distributional equity, and social justice away from public affairs to private affairs. It argues that individual compassion without government accountability is inadequate to make large scale structural changes required to address social problems. This section also claims that shifting the responsibility dilutes the collective accountability of social justice. It depoliticizes the suffering of the community and, consequently, 
allows the city government to wash its hands off from the responsibility of addressing the social problems that cause the suffering. Furthermore, shifting the responsibility to the individuals helps the city government entrench its neoliberal governance that only serves the market, with no accountability for welfare distribution to the marginalized groups.

The fourth section critiques the discourse of compassion for being inconsistent with rights. It argues that discourse of compassion strips the political rights of the marginalized communities to demand the alleviation of their sufferings- that their distress should be addressed not out of the mercy of someone but because of their right as a citizen. It dismantles the notion that issues such as marginalization, poverty, inequity, and suffering are a matter of social justice that calls for collective and institutional actions. It leaves marginalized communities in a state of precarity where they do not have any guarantee of alleviation of their suffering.

Taking these critiques together, the chapter claims that the discourse of compassion does not address Louisville's chronic social problems. On the contrary, it helps to aggravate them through the further entrenchment of neoliberalism in Louisville. Neoliberalism, as understood in this dissertation, is a totalitarian, oppressive, and discriminatory political system that is modeled on the principles of entrepreneurialism, where society relies on market forces to address political problems. It calls for smaller government that takes no accountability for distributive justice and privatizes welfare distribution (Peck 2017; Vincent, 2010; Peck 2010; Schecter 2010; Larner 2006; Ferguson 2010; Hall 2011; Harvey 2007; Dawes and Lenormand 2019; Protevi 2009). The discourse produced by the Compassion in Louisville moralizes the neoliberalism and its strategy of 'rolling-back' the government's responsibility for welfare provision to individuals and business actors 
(Peck and Tickell 2002). Compassion in Louisville, therefore, can be seen as an aid to neoliberalism that depoliticizes social problems, displaces rights, and reproduces precarious communities.

\section{WHERE IS YOUR COMPASSION?}

Khalil Gibran, the Lebanese-American poet famously penned: "How mean am I when life gives me gold and I give you silver, and yet I deem myself generous." This statement sums up the biggest critique of the claim of Louisville to be a "Compassionate City." Louisville is fraught with distressed communities suffering from social problems such as inequality, poverty, homelessness, health disparity, and racial segregation. This section argues that the city government of Louisville has done very little to date to address these social problems to call itself compassionate. In essence, the argument is that the claim of the "Compassionate Louisville" is a misleading rhetoric- that the city government does not actually act compassionately towards the marginalized communities of the city.

Louisville is plagued with striking economic, social and health inequality. According to a report by Economic Innovation Group (2016), Louisville is ranked as the 11 th unequal city with over 500,000 people in the US. The average income of the top $20 \%$ of Louisville residents is 15.7 times greater than the average income of the bottom 20\% ((Greater Louisville Project, n.d. $)^{63}$. About 1 in 5 children in Louisville live in a household where the median income is $\$ 11,000$ (Buchino, et al., 2019). Much of this economic inequality is geographically and racially segregated along the infamous 9th street divide, where to the West of the divide resides people of color

\footnotetext{
63 “Income Inequality," Greater Louisville Project, accessed May 28, 2020. retrieved from: https://greaterlouisvilleproject.org/factors/income-inequality/.
} 
with concentrated poverty and to the East of the divide resides affluent white people. About 24\% of West Louisville is unemployed (Greater Louisville Project, 2015). Even when employed, a majority of West Louisville residents work in low wage jobs earning a median income below \$20,000 (Greater Louisville Project, 2017).

As often observed in other US cities, income inequality in Louisville brings about other social disparities within the city. Take house-ownership disparity in Louisville, for example, where 70 percent of white residents are homeowners compared to only 40 percent among Black and Latinx families. Affordable housing can meet only 46 percent of the need for low-income families with an estimated shortage of over 31,000 units (Louisville Metro Affordable Housing Trust Fund, 2019). Additionally, homelessness is an issue that plagues Louisville: In 2019, there were about 7000 homeless people living in the streets (Rust, 2019) ${ }^{64}$. Such inequalities also transcend to other social issues. Black community concentrated in the West Louisville also experience chronic stress of community violence with a homicide rate of 5.5 times higher than the affluent East (Pryor, et al., 2017).

Socio-economic inequality of Louisville results in grim health disparities along the geographical divides of East and West. Due to the high percentage of poverty in West Louisville, fewer people can afford health insurance, resulting in about 25 percent of West Louisville residents being uninsured (Centers for Disease Control and Prevention, 2014). The overall life expectancy in Louisville is 76.8 years; however, life expectancy falls by as much as 12.6 years for individuals living west of the 9th street divide. Infant mortality in the Black population was recorded 1.95 times

\footnotetext{
${ }^{64}$ Kaitlin Rust, "Louisville's homeless population has increased, but less are sleeping on the streets." Wave3 News, April 29, 2019, retrieved from: https://www.wave3.com/2019/04/20/louisvilleshomeless-population-has-increased-less-are-sleeping-streets/.
} 
higher than for the overall Louisville Metro population from 2011- 2015; 2.31 times higher than for white babies; and 2.88 times higher than for Hispanic babies. The health disparity of Louisville can also be observed by the rate of morbid diseases. For example, black people compared to the overall city have two times the rate of death due to heart disease, two times the rate of death due to diabetes, and three times the rate of death due to stroke. However, death and morbid diseases are not the only metrics for the health disparities of Louisville. Take, for example, the lead level found in the blood of children- about 1500 children have blood lead levels that are $5 \mu \mathrm{g} / \mathrm{dL}$ or higher, almost all of which are found in the West Louisville neighborhoods. Teenage black girls are being tested and diagnosed with chlamydia, gonorrhea, and syphilis at higher rates than any other teenage demographic. In 2015, their rates were 2.76 times higher than black boys, 5.06 times higher than white girls, and 26.7 times higher than white boys. Obesity rates are disproportionately high in West Louisville neighborhoods-about $72.7 \%$ of black adults are overweight or obese, which is higher than the rates of overweight and obesity among whites (61.8\%) in the city (Pryor, et al., 2017).

The list of disparity ty in socio-economic indicators can be stretched even further, and all of which would reflect only one thing- that Louisville, like most American cities, has two sides. One side with a wealthy white population and the other struggling with concentrated poverty of people of color. In the presence of such dichotomous living standards and life opportunities, it is all too fair to question the city's claim to be compassionate, especially when considering how little the city government has done to address these disparities.

Take the case of the program 'Mayor's Give A Day Week' (MGAD). The event is branded as the flagship compassionate program of the city and provides 
Louisville the regional and international attention as the "Model Compassionate City" for five consecutive years. MGAD provides the platform to residents of Louisville to volunteer in different social projects. In 2019, about 205,000 people volunteered for a day in different social projects such as building beds for schools, cleaning neighborhoods, donating blood, and planting trees Louisville-Jefferson County Metro Government, 2019) ${ }^{65}$. The complete list of the projects in MGAD is given in Appendix D. While most of the volunteer projects in MGAD are commendable, none of them address the core issues that plagues Louisville. Cleaning neighborhoods is important, but does it alleviate the suffering of the concentrated income inequality in West Louisville? Planting trees are noble, but does it address the suffering of the lack of affordable housing or homelessness? Donating blood is essential, but how does it alleviate the health disparity of the city? Not to demean any of the initiatives under MGAD; however, none of them alleviate the chronic structural suffering experienced by the marginalized communities of Louisville. Moreover, it begs the question of how one day of volunteering out of 365 days in a year of systematic social, economic, and health inequity makes Louisville the "Model Compassionate City" of the world?

This question of "where is compassion" in Louisville is especially relevant if you consider how little the city allocates its resources to address the profound inequality of the city. A simple analysis of the recent city budget shows disproportionate distribution of fiscal resources to address the social sufferings (Appendix E shows the FY20 budget of the city of Louisville with analysis). In the fiscal year of 2019-20, Louisville budgeted an expenditure of $\$ 876$ million that

\footnotetext{
${ }^{65}$ Mayor rallies community for eighth annual Give A Day Week of Service." Louisville-Jefferson County Metro Government, April 2019, accessed April 30, 2020 retrieved from: https://louisvilleky.gov/news/mayor-rallies-community-eighth-annual-give-day-week-service-april-1320.
} 
includes \$624 million of General Fund and \$120 million in debt servicing. About $60 \%$ of the General Fund is spent on public safety agencies including Louisville Metro Police Department, Youth Detention Services, the Department of Corrections and the Criminal Justice Commission (See Appendix E for the budget allocation of Louisville for FY2020). This implies that about two-thirds of the city expenditure is used to police and jail people of Louisville. Even if I do not go into the argument that such heavy investment in policing is a sign of the systematic production of inequity, racism and incarceration, I can still argue that it leaves very little city resource to be allocated in addressing the suffering of the poverty and disparity. In fact, in the fiscal year 2020, Louisville spent about only $\$ 1$ million for homeless services $(0.16 \%$ of the General fund), \$5 million for affordable housing ( $0.8 \%$ of the General Fund) and \$2.9 million in Health Equity programs $(0.46 \%$ of the General Fund) (Louisville Metro Government, 2019) ${ }^{66}$.

If you juxtapose the social problems of the underprivileged communities in the city with the fiscal budget allocations and once a year volunteering project, the question of "where is compassion" is even more glaring. Add to that the local fiscal revenue structure: the affluent 1 percent of Louisville pay only 6.7 percent of their income while the poorest 20 percent pay 9.5 percent (Institute on Taxation and Economic Policy, 2018). The picture these numbers paint is a portrait of a city with structural unequal distribution of fiscal revenue and expenditure, where an already segregated and concentrated poverty is entrenched and reproduced. It is a city where poverty and inequity are systematically designed; a city where the affluent of the East continue to be rich and the impoverished people of the West linger in suffering; and a

\footnotetext{
66 "Fiscal Year 2019-2020: Louisville Metro Approved Executive Budget." Louisville-Jefferson County Metro Government, 2019.
} 
city which claims to be the "model compassionate city" of the world by giving only negligible fiscal allocation and once a year volunteerism by the privileged! It brings back to the quote of Khalil Gibran: "How mean am I when life gives me gold and I give you silver, and yet I deem myself generous.”

\section{COMPASSION AS A POLITICAL STRATEGY}

This section argues that various political actors in Louisville often invoke the discourse of compassion as a strategy to moralize their political position. The discourse produced by the Compassionate Louisville connects compassion with

altruism, generosity and, most importantly, morality. As quoted by an interviewee, "If you do not aspire to be compassionate, then I think you have something lacking in your humanity." There is a notion of moral superiority with the narrative of compassion. It pushes the idea that political position that is framed with the narrative of compassion is moral, and any opposition to such narrative is unethical. This section argues that the moral loftiness associated with the discourse of compassion is hijacked by political actors to justify position, strengthen arguments, and distract criticism. In other words, the discourse of compassion is concerned less about alleviating the suffering of the oppressed or addressing social issues; instead, it is propagated as strategic political rhetoric to provide moral legitimacy.

As discussed in chapter 3, the discourse of compassion is increasingly used by various actors in Louisville: from faith-based organizations to restaurants, from rightbased activists to city officials. A valid question is why is the narrative becoming increasingly popular? One explanation could be that there is a natural association with the narrative of compassion and the mission of some of the organizations/activists. Healthcare and care organizations, for example, have a long tradition of association 
with compassion in their service because of the very nature of the industry. Similarly, it can be argued that faith-based organizations tend to gravitate towards the narrative of compassion because of the inherent presence of the rhetoric of compassion found in most theologies. Likewise, social activists/groups might have created their association with the narrative of compassion because it complements their cause.

However, it is hard not to acknowledge that at least some of the associations with the language of compassion in Louisville are strategic. The popularity of the discourse of compassion in Louisville provides avenues for political actors to be strategically associated with its language as a "safe word" (Ruez and Parekh 2019). Because the discourse of compassion holds moral loftiness, it becomes a safe option for organizations/groups to ride the popular rhetoric to claim political acceptance. Take the case of the Louisville Islamic Center, discussed in chapter 3, which rebranded itself as Louisville Islamic Center of Compassion in 2017. Riffat Hassan, a former religion professor of the University of Louisville, claims that the rebranding and association with compassion was a defensive strategy by the Muslim community to gain acceptance and fight Islamophobia. She claims that by rebranding themselves with the popular narrative of compassion, the Islamic center is emphasizing that they are "Compassionate Muslims," which is categorically different than "regular Muslims." This, according to Hassan, is a strategy to ride the popular and acceptable narrative of compassion to be assimilated into the city. In Hassan's word, "As I see it, what was wrong with the rebranding of the LIC as the Center of Compassion is precisely what needs to be redressed in the U.S. at this time when so many minority 
groups feel that they have no choice except to use safe words in order to protect themselves from discrimination or harm" (Hassan, 2017) ${ }^{67}$.

The perception of the moral superiority of compassion is also strategically used by the city administration to add moral legitimacy to controversial political positions. The discourse of Compassionate Louisville glorifies compassion as an idea that is noble, magnanimous, and benevolent. The city administration has often used this moral superiority of compassion to justify their action. Take the case of the use of the discourse of compassion in defense of the city's regular drive to dismantle homeless camps. The city administration justifies the homeless camp destruction drive claiming it is the compassionate thing to do(!). Mayor Fisher in 2017, for example, argued that it was compassionate to destroy homeless camps because they pose public health concerns: "People are saying 'should we clean a camp out, is that the compassionate thing to do?' Is it a compassionate thing for a camp to be a breeding ground for hepatitis A? (Louisville Future, 2017) ${ }^{68}$. The city further claims that it follows a very compassionate process to dismantle the homeless camp (Sayers \& Bailey, 2017 $)^{69}$ ! These examples show that the use of the discourse of compassion by the city government is a 'straitjacket strategy' that is used not to address social problems but to extend a moral legitimacy on their actions. Once a political claim has

\footnotetext{
${ }^{67}$ Riffat Hassan, "Is 'compassion' the safe word for Muslims?” Courier Journal

68 "Fischer suspends clearing of homeless camps until notification ordinance is passed," Louisville Future, 18 December 18, 2017, retrieved from: https://louisvillefuture.com/archived-news/fischersuspends-clearing-of-homeless-camps-until-notification-ordinance-is-passed/.

${ }^{69}$ Justin Sayers, and Phillip M. Bailey, "Louisville helps homeless man as his camp is wiped out, but others aren't as lucky." Courier Journal, December 8, 2017, retrieved from: https:/www.courierjournal.com/story/news/politics/metro-government/2017/12/08/homeless-camp-razed-downtownlouisville-compassionate-city/934026001/.
} 
been made with the narrative of compassion, it is difficult to challenge or oppose the claim (Ruez \& Parekh 2019). Opposing the claim subsumed in the narrative of compassion becomes an attack on compassion itself, and thus the opposition runs the risk of being seen as apathetic, ignoble, and even immoral. This moral legitimacy the narrative lends, thus, provides a strong strategic advantage to evoke the logic of compassion. Yet, these actions wrapped in the moral loftiness, do not necessarily address the social problem.

\section{RIGHTS VS COMPASSION}

This section critique the discourse of compassion to argue that compassion cannot be a substitute for rights. On one hand, rights are entitlements of citizens in order to be in a particular state or receive certain benefits. Rights are closely associated with a notion of justice. It establishes a universal set of views and practices that are acceptable and unacceptable in society (Stanford Encyclopedia of Philosophy, 2020). Unlike compassion, which is desirable but may not be obligatory, rights are viewed as enforceable. As John Stuart Mill $(1859,54)$ puts it: "When we call anything a person's right, we mean that he has a valid claim on society to protect him in the possession of it, either by the force of law, or by that of education and opinion... To have a right, then, is, I conceive, to have something which society ought to defend me in the possession of". Thus, right-holders are sovereign free individuals who can make a legal and moral claim based on their rights (Hart, 1982). In other words, rights are something that can be demanded. Moreover, because of the social enforcement of rights, it is uniformly applicable to all right-holders - creating solidarity in society, at least in principle. 
On the other hand, compassion is a divisive practice (Kaika, 2017; Marks, 2007). The discourse of compassion tends to divide people into groups: one that is weak, suffering, objects in need help, and the other group of powerful, wealthy, kind, and generous. The act of compassion is an act where the second group (powerful, resourceful, and benevolent) bestows kindness and generosity on the first group (who are weak and in distress). It is a social privilege over the sufferer from whom the privileged have a comfortable distance (Berlant 2004). People who are suffering, visà-vis the poor, the marginalized and oppressed, are being treated as voiceless victims of a preventable evil who can be saved by a wealthy philanthropist (Eikenberry \& Mirabell, 2018).

Trailing from these arguments of rights versus compassion, this section makes three related critiques. The first critique is that compassion divides society by two classes: one a group of elite philanthropists and another of the marginalized in need of help from the elites. The second critique relates to the unenforceability or voluntary nature of compassion. This unenforceability of compassion means the suffering of the marginalized community cannot be guaranteed. The third critique is that the politics of compassion displaces the rights of marginalized communities who become ever dependent on the compassion of the powerful.

The first critique of the discourse of compassion is that it is a divisive practice. It divides society by two classes: the powerful, resourceful, who are the benevolent philanthropists, and the have nots, distressful, who are seen as objects of need and mercy. Take, for example, use of the narrative of compassion related to the Minimum Wage debate in Louisville, as discussed in chapter 3. In the Ordinance of Minimum Wage of 2014 of the city of Louisville which states in the first sentence: "Louisville has been recognized as a Compassionate City it is incumbent upon us to take 
legislative steps to help lift working families out of poverty, decrease income inequality, and boost our economy" (Metro Council, 2014; See Appendix H for transcript of the meeting minutes). The debate of minimum wage usually corresponds to the discourse for rights to economic equity, economic justice, or standard of living. In this case, however, the discourse minimum wage is not based on these rights, but on the basis that it is the "compassionate" thing to do. This fundamentally transforms the poor people living on the minimum wage into objects that need help rather than citizens who have rights for equity and poverty alleviation.

This argument of dividing the society into classes of powerful and objects of need is applicable across all cases identified in Chapter 3. For example, the Occupy ICE protests of Louisville, which claimed immigrant rights based on compassion, transform the undocumented immigrants into objects of mercy instead of rightbearing individuals. Similarly, the use of the discourse of compassion in homeless issues positions the homeless as objects of need. Mayor Fisher has addressed homeless issues saying, "We have to help our homeless population deal with and overcome their challenges one person at a time. That's what a compassionate city does" (Spectrum News 2019) ${ }^{70}$. These discourses emphasize that the homeless community does not have the political right to demand essential services from the city. Rather, they are a helpless community who need to be cared for by the well off, wealthy individuals.

The second critique relates to the unenforceability of compassion due to its voluntary nature. One of the big distinctions of compassion and rights is that compassion is not enforceable. For 'compassion' to remain as 'compassion', it needs to

\footnotetext{
70 Spectrum News. "Mayor Announces Funding to Help Homeless Individuals and Families."
} 
be voluntary acts of benevolence. If an alleviation of suffering can be demanded, it loses the quality of being an act of 'compassion'; it becomes a matter of rights.

Compassion, therefore, cannot be enforceable. We cannot hold individuals to be kind to one another, to give charity, or to altruistically alleviate the sufferings of others they are not responsible for. One cannot be held legally or morally accountable for not being compassionate. Moreover, compassion can also be inconsistent in response to perceived suffering, especially when it is in a conflict of self-interest (Arendt, 1963; Whitebrook, 2002). To put simply, it is easy to show kindness, be generous, and act compassionately when it does not conflict with self-interest. However, it is quite a different situation when acting compassionate has a personal cost. Take the case of the use of compassionate language in the issue of homelessness in Louisville. The narratives revolve around the idea that homeless people are in legitimate need of help and deserve our compassionate attention. I do not question this sentiment- it is safe to assume most people acknowledge the sufferings the homeless people experience. However, this feeling of compassion is often found to be fleeting when the homeless issue arises in their own neighborhood. In Louisville, for example, both the local businesses and neighborhood residents complain about the homeless occupying public space, creating visible nuisance, accumulating trash and generating crimes. The presence of homeless camps in the vicinity of a neighborhood evokes fear of loss of business and a sense of neighborhood quality (Gardner, 2019) ${ }^{71}$. This frequently results in dismantled homeless camps in neighborhoods. Such acts exemplify how individual compassion is exercised only from a safe distance from which it does not

\footnotetext{
${ }^{71}$ Drew Gardner, "Louisville neighborhood frustrated by growing homeless camp." WLKY, November 11, 2019, retrieved from: https://www.wlky.com/article/louisville-neighborhood-frustrated-bygrowing-homeless-camp/29765856.
} 
conflict with our own interests and privileges. Once individuals are faced with the conflict of self-interest, the flimsiness of the discourse of compassion to address the social ills becomes exposed.

An advocate of compassion might counter the argument insisting that these individuals are not taking their compassion far enough. However, the issue remains that compassion is voluntary. There is no moral and legal enforcement possible on individuals to act compassionately towards another. Therefore, to what extent individuals will sacrifice their self-interest to extend compassion rests on the discretions of individuals. This voluntary nature of compassion along with inconsistency of action means the alleviation of suffering is never a guarantee. This leaves people in distress in a state of precarity where there is no assurance their suffering will be alleviated. Rather relief from distress is dependent on the benevolence of the privileged who may or may not extend their kindness. The individuals or groups who are suffering, therefore, remains at the mercy of the powerful and resourceful benevolent (Marks, 2007; Kaika, 2017; Nussbaum,1996; Berlant, 2004; Singleton \& Mee, 2017).

The third critique is that the politics of compassion displace the rights of the marginalized communities. Consider the case of the use of the narrative of compassion in LGBTQ activism of Louisville, "Louisville is a compassionate city where everyone is welcome" (Louisville-Jefferson County Metro Government 2019) ${ }^{72}$. This implies that the LGBTQ community is accepted and welcomed in Louisville not because it is their right to exist or for the freedom to choose their

\footnotetext{
72 “Mayor Fischer declares June 10-17 Pride Week in Louisville," Louisville-Jefferson County Metro Government, 2019, accessed May 20, 2020, retrieved from: https://louisvilleky.gov/news/mayorfischer-declares-june-10-17-pride-week-louisville.
} 
identity, but because Louisville is "Compassionate." By accepting the community in the city, Louisville is showing benevolence. Similarly, the healthcare (UofL Physicians 2016) ) $^{73}$ and religious services (Cathedral of Assumption n.d.) ${ }^{74}$ extended to the LGBT community are also justified with the narrative of compassion. It implies that access to basic health and religious services are not rights of the LGBTQ community that can be demanded. This effectively displaces the rights of the LGBTQ community to demand freedom of choice and equal access to basic services.

One can argue that rights or not, the LGBTQ community of Louisville is at least accepted and is provided access to services even if it is in the name of compassion. What bad is compassion doing? The response to this argument lies in the voluntary nature of this acceptance and access to the services. The parable is akin to that of the scenario of refugees taking refuge in a foreign state- while refugees are accepted in a foreign land, they are not given the rights of the citizens of that land. Their acceptance is conditional on the benevolence of the state. This benevolence can be taken away without any repercussions. There always remains the difference between right-bearing citizen who can demand their rights and people who are given certain access out of compassion. Receivers of compassion always remain subservient to their providers. Similarly, the services and acceptance that the LGBTQ community enjoys out of compassion can be wiped away without any moral and legal obligation. For the continued access to services and acceptance, the community needs to remain at the mercy of the privileged. Unless the access to these services are instituted as rights of the LGBTQ community, they remain akin to being refugees in their own city

\footnotetext{
73 "LGBTQ Care", UofL Physicians

74 “Compassion,” Cathedral of Assumption
} 
- never equal to right-bearing citizens and ever depending on the compassion of others for access to services.

\section{PRIVATIZING THE RESPONSIBILITY OF WELFARE}

This section critiques the discourse of Compassionate Louisville for shifting the responsibility of issues such as welfare provision, distributional equity, and social justice away from public affairs to private affairs. Louisville's approach to compassion has not been institutional: the government of Louisville does not actively seek to acknowledge the sufferings and allocate government resources to alleviate them. In fact, over the decade of Compassionate city branding there has never been a single budget line allocated to compassionate related programming. Instead, Louisville's approach to compassion has been to promote compassionate acts by its residents, either individually or through their businesses and religious organizations. As the website page of the government's Compassion City states: "There's a role for all of us in making sure no one is left behind or goes wanting" (Louisville-Jefferson County Metro Government n.d. $)^{75}$.

This section argues the discourse of compassion established by the city government involves the idea of responsibilizing individuals to make social changes with the underlying assumption that much of the social problems that plague the city can be resolved by individual compassionate behavior. Take the example of Mayor's Give A Day Week’ (MGAD), Louisville’s flagship compassionate program. MGAD provides the platform to residents of Louisville to volunteer in different social

\footnotetext{
75 "Goal 21: Grow as a Compassionate City”, Louisville-Jefferson County Metro Government, accessed May 20, 2020, retrieved from: https://louisvilleky.gov/government/mayor-gregfischer/strategic-plan-2017/goal-21-grow-compassionate-city.
} 
projects. In 2019, about 205,000 volunteered for a day in different social projects, such as feeding the homeless and cleaning neighborhoods (Louisville-Jefferson County Metro Government, 2019) ${ }^{76}$. While these individual contributions are laudable, it can also be read as a shifting of responsibility of social issues to the volunteered compassionate individuals. Another example could be how city government of Louisville frames their response to the homeless issue. The opening statement the city government of Louisville published on its website in regards to addressing the issue of homelessness:

"It will take all of us in this compassionate community - government, individuals, places of faith and businesses - to make a real impact in addressing Louisville's homelessness" (Louisville-Jefferson County Metro Government n.d.) $)^{77}$.

It would be unfair to argue with this statement that the city government does not have any provisions and programs for the homeless in Louisville. Although inadequate, the city government has some initiatives which help the community. Moreover, a call for concerted actions across various actors to address the homeless community can indeed be a strategically sound approach. However, this approach of calling for compassion across various actors can also be read as passing the responsibility of addressing the issues of the homeless. The statement can be read as the government's suggestion that addressing the homeless issue is not a public affair alone, and thus government cannot be held accountable to manage the issue.

This section outlines four critiques of passing the public responsibility of issues of social justice and responsibilizing individuals. The first critique is simply

\footnotetext{
76 “Mayor rallies community for eighth annual Give A Day Week of Service," Louisville-Jefferson County Metro Government, 2019, accessed April 30, 2020, retreived from: https://louisvilleky.gov/news/mayor-rallies-community-eighth-annual-give-day-week-service-april-1320.

77 “Helping our Homeless Neighbors,” Louisville-Jefferson County Metro Government.
} 
that individual compassion is insufficient to address social justice. Compassion at the individual scale comes from our emphatic sense of the distress of others. However, this empathic distress may not necessarily render actions (Arendt 1963). Or even when it is accompanied by an action, it is only acted on to satisfy the emphatic distress experienced by the witness. This means that an individual may satisfy their own emotional need by completing acts of compassion towards another which do not completely alleviate the actual distress of the sufferer. In simpler words, people may deem themselves to be compassionate with acts that fall short of solving the distress of the sufferer but quenches their own emphatic sense of kindness. Let's recall the case of MGAD event of Louisville. The event provides a platform for city residents to volunteer for one day in social projects to cook food for homeless, plants trees, cleans neighborhood or donate blood (Louisville-Jefferson County Metro Government, 2019) ${ }^{78}$. However, while these acts of compassion one day of the year do provide the volunteers a sense of contribution in the community, it does not solve the daily sufferings of the marginalized community of Louisville. The homeless remain homeless, the health disparity remains unresolved, and the poor remain in misery for the remainder of the year. More importantly, much of the issues of social injustice and inequity cannot simply be addressed by individuals largely because these issues are perpetuated by structural circuits of global capital and its perverse relationship with both local and federal governments (Harvey, 1982; Lefebvre, 1968). Addressing these issues requires concerted institutional efforts that challenge existing oppressive structures. Relying on the individuals acts of compassion without the structural change can at best momentarily soothe the suffering, but it cannot alleviate it.

\footnotetext{
78 “Mayor rallies community for eighth annual Give A Day Week of Service," Louisville-Jefferson County Metro Government, 2019
} 
The second critique of placing the responsibility of social issues on the compassion of individuals relates to the discussion of rights made in the above section. Compassion is voluntary by nature as there are no legal or moral obligations of compassionate actions. It cannot be demanded, nor can it be enforced. Because there is no enforceability of compassion, individuals who are now entrusted to address social issues always have the option to choose to act; that is, they may or may not act compassionately. This leaves people in distress, such as those who are suffering due to lack of access to health care, homelessness, segregation, or poverty, in a state of precarity where they do not have any guarantee of alleviation of their suffering. Additionally, the combination of the city's pushing away its responsibility for social issues and the unenforceability of compassion at the individual scale essentially dilutes the accountability of the suffering where no one is responsible. This dismantles the notion of social justice as a matter of rights that demands a collective and institutional response.

The third critique relates to depoliticization of suffering. By passing the responsibility of the government to the individuals, politics is taken out of the equation in managing issues of social justice. Rather issues of social justice are seen as private philanthropic opportunities where benevolent individuals decide who receive social welfare instead of elected officials (Nickel \& Eikenberry, 2010; Eikenberry \& Mirabell, 2018). Sufferings, distress and alleviation of these suffering, therefore, become a private matter instead of public matter. It is privatization of welfare that creates what Berger and Penna (2013) described as "charitable imperialism where rich individuals determine what and whose suffering will be acknowledged, and how that will be addressed. 
Additionally, depoliticization also helps city government to wash its hands of the responsibility to alleviate suffering and perpetuates the social problems that causes the suffering. Marginalized people are seen as people who have randomly existed into their misery, ignoring the historical and present regime of political structures that causes the misery. Take the case of wealth disparity of Louisville: the average income of the top $20 \%$ of Louisville residents is 15.7 times greater than the average income of the bottom 20\% (Greater Louisville Project, n.d.) ${ }^{79}$ and about 1 in 5 children in Louisville live in household whose median income is $\$ 11,000$ (Buchino, et al., 2019). The suffering of Louisville's low-income community comes from historical racial barriers producing wealth enacted by the state through policies such as redlining and urban renewal. By passing the responsibility of the government to address these social issues to the individuals, the city assumes a position of innocence and takes no political accountability to the marginalized communities. For a more recent example of suffering produced and maintained by the city government's action, take the case of the homeless issue of Louisville. On one hand, the city government preaches to individuals for acknowledgment of the suffering of homeless communities. On the other hand, much of the suffering of the homeless community in Louisville is a direct result of the city government's rules. For example, according to City Code 13203(A)(18), it is illegal to sleep in public in Louisville "during the hours of darkness"a code frequently used to dismantle homeless camps around the city even during harsh winter. Similarly, the Pedestrian Safety Ordinance criminalizes panhandling on the streets, sidewalks and medians which severely affects the source of income for the

\footnotetext{
79 “Income Inequality,” Greater Louisville Project
} 
homeless $(\text { Costello, 2019) })^{80 .}$ The problem goes even deeper when you take into account the structures that produce homelessness: evictions, inadequate affordable housing and lack of fiscal allocation of city government in regard to these issues. According to the Kentucky Center for Investigative Reporting, the eviction rate of Louisville is two times higher than the national average (Ryan and Kanik, 2018) ${ }^{81}$. Additionally, affordable housing in the city can meet only 46 percent of the in need low-income families with an estimated shortage of over 31,000 units (Louisville Metro Affordable Housing Trust Fund, 2019). The fiscal response to this growing crisis that contributes to homelessness is meager in contrast: in 2019, the city government has spent about $0.8 \%$ of the budget on affordable housing and $0.16 \%$ on homeless services. By not taking responsibility of such social problems and passing it down to the disposal of individual compassion, the city government denies the acknowledgement that certain sufferings are caused by its own policies. Instead, the city assumes an image of the innocent benevolent caller of individual compassiondevoid of any misdoings and unaccountable to the sufferings of the communities.

The fourth critique of passing the city's responsibility of social issues to individuals relates to the role of the city government in providing welfare to address the suffering of the people. If the city government of Louisville, through depoliticization of suffering, passes the responsibility of addressing the issues of social justice to individuals, what then is its role? If it does not take accountability for

\footnotetext{
${ }^{80}$ Darcy Costello, " Metro Council passes a safety ordinance that restricts panhandling, but with a few tweaks," Courier Journal, August 8, 2019, retrieved from: https://www.courierjournal.com/story/news/politics/metro-government/2019/08/08/louisville-metro-council-passesordinance-intersection-panhandling/1955017001/.

${ }^{81}$ Jacob Ryan and Alexandra Kanik, "Instability Grows As Louisville Eviction Rate Doubles National Average." Kentucky Center of Investigative Reporting, July 5, 2018, retrieved from: https://kycir.org/2018/07/05/eviction-in-louisville
} 
the suffering of the people, then what does it do? Scholars (Eikenberry \& Mirabell, 2018; Dean 2015; Henriksen, Smith, and Zimmer 2012) have argued that such approach of 'rolling-up' the responsibility of the government for welfare provision to individuals and business actors is a trademark neoliberal strategy. The role of the state under neoliberalism is limited to creating an enabling environment for market mostly by instituting property rights, upholding contract laws, maintaining stability and reducing restriction on market operation (Hayak, 1944).

Louisville's political approach, like most US cities, has always been neoliberal and, as Ruez \& Parek (2019) claims, the decade-long compassionate city initiative did not result in a shift of this strategy. A simple analysis of the fiscal budget of Louisville shows the neoliberal logic embedded in its resource allocation: about 53\% of the city budget in fiscal year 2020 (see Appendix E) is apportioned for public safety (read policing) with insignificant allocation for welfare. This indicates the priority of the city is not alleviating suffering of its people but maintaining the social order required for market operations. More importantly, the narrative of compassionate city that urges its residents to address the social problems through individuals acts of compassion and philanthropy is a narrative that further entrenches neoliberalism in Louisville. It allows the city government to only serve the market functions, takes no accountability of the suffering of the people, and responsibilize individuals for their own welfare- all in the disguise of a moral high ground of compassion.

\section{CONCLUSION}

This chapter critiques the discourse of compassion and the use of its logics in Louisville. The discourse produced by the Compassionate Louisville propagates the 
idea that individual compassion is not only a moral virtue that everyone should have but also the solution to the chronic social issues of the city. This chapter argues that compassion cannot and does not address the social problems of Louisville, such as inequality, poverty, homelessness, health disparity, and racial segregation. Instead, the discourse of compassion helps to perpetuate the social problems of Louisville.

The chapter argues that the discourse of compassion shifts the responsibility of welfare provision away from public affairs to private affairs. It responsiblizes individuals for taking care of the distressed and marginalized through philanthropy. However, the chapter critiques that individual compassion alone is inadequate to address the social problems of Louisville, largely because these issues are perpetuated by structural circuits of global capitalism.

The chapter also critiques the discourse of compassion for displacing the rights of the marginalized community. It shows that the discourse of compassion tends to divide society into two groups: one that comprises of people who are seen as weak, objects in need of help; and the other group of powerful, wealthy, and philanthropic. This divisive logic transforms the marginalized communities as voiceless victims in need of help, care, and mercy. It effectively strips the political rights of the marginalized communities to demand the alleviation of their sufferingsthat their distress should be addressed not out of the mercy of someone but because of their right as a citizen.

Moreover, the logic of compassion is argued to be inconsistent to the notion of justice. Compassion is, by definition, voluntary: individuals cannot be legally or morally held accountable to be kind to one another, to give charity, or to alleviate the sufferings of others altruistically. Compassion, therefore, cannot be demanded. Putting the responsibility of social issues on the compassion of individuals, thus, 
leaves marginalized communities in a state of precarity where they do not have any guarantee of alleviation of their suffering. In other words, it dismantles the notion that issues such as marginalization, poverty, and inequity, are a matter of social justice that calls for collective and institutional actions. Rather, the relief from such social distresses is dependent on the benevolence of the privileged who may or may not extend their compassion.

More importantly, the discourse of compassion lends a moral mask on neoliberalism. The discourse of compassion produces the idea compassion is the highest standard of morality. The discourse helps to moralize the idea that the role of addressing the suffering of the disenfranchised community does not fall on the government, but on the individuals. This allows the city government of Louisville to wash its hands off from the responsibility of delivering welfare and social justice. In other words, the discourse of compassion helps to create the ground for neoliberalism to be morally legitimate. 


\section{CHAPTER 5 - COMPASSION AS EMOTIONAL GOVERNANCE}

\section{INTRODUCTION}

The discourse produced by the Compassionate Louisville brand propagates the idea that many of the social problems which plague the city can be resolved by individuals who are empathetic, benevolent, and compassionate. However, the critiques presented in the previous chapter show that the discourse of compassion cannot and does not address the social problems of Louisville. This chapter follows with the question of what then is the purpose of the Compassionate Louisville brand?

To do so, it explores the Compassionate City brand as an apparatus of governmentality. City branding has been described as a conscious strategy to create and manage the beliefs, identity, values, and expectations of people (Oguztimur \& Akturan, 2015; Kavaratzis \& Ashworth, 2005; Pasquinelli, 2013; Schwak, 2016; Volcic \& Andrejevic, 2011). As discussed in Chapter 3, city branding does not happen in a political vacuum. Instead, it is produced in conjunction with the city dwellers, who in their act of dwelling, voicing, imagining, and consuming the city make the image of the city (Green, Debra, \& Perkins, 2016). This politicking to produce and maintain a brand involves manufacturing a political discourse of what the image of the city is or what the city stands for. This discourse forms a certain social logic that guides how citizens under the branded place should think, act, and be. Through participation in the branding process and by performing according to the set 
brand expectations, citizens enroll themselves in the domain of social rationalities that influence, control, and govern their behavior (Eshuis \& Edwards, 2013). Thus, by '"living the brand", people transform themselves into self-regulated citizens who think and behave in the domain of discourse produced by the city brand (Lucarelli, 2018; Volcic \& Andrejevic, 2011; Jokela 2020).

This chapter uses this analytical lens to explore how and why the Compassionate City brand disciplines the people of Louisville. To make this argument, the chapter briefly reviews the literature that connects governmentality with emotional governance. Contributors of this literature argue that emotions are integral to social relations required for perpetuation of neoliberalism, envisioned as both an ideological and an economic framework (Kiersey, 2014; D'Aoust, 2014; Vrasti \& Montison, 2014). In other words, a certain emotional configuration is required for the circuits of production to work. They further argue that specific emotional configurations produce specific materiality, experiences, and social normality. Conceptualized in this way, emotions mediate the process of meaning formation of the world and self. Thus, transformation market ideology into a normative framework that guides citizens to think and make decisions requires a degree of emotional subjectivity. In this regard, the state takes the emotional life of individuals and collectives as an object of governance to maintain the circuits of the "population wealth." State deploys governmental technologies that guide individuals to experience certain emotions that are 'productive' while inhibiting other forms of emotions.

The recent trend of humanitarian governance, which is imbued with the narrative of caring for the distressed and empathy towards suffering, is argued to be one such approach to discipline the emotion of people. The humanitarian governance 
approach deploys a new definition of inclusion/exclusion where care is deployed according to the rationality of 'legitimate' suffering. In doing so, it brings into marginalized people under the arch of state governance with the underlying logic securitization and maximization of population wealth. Humanitarian governance deploys certain emotional settings that 'manage' the need of the marginalized and disfranchised communities to the extent to which it can participate in the circuits of production. However, the humanitarian approach is not limited to managing precarious individuals; it also has a role in governing the emotion of the overall population. It serves the role of managing the configuration of emotions to induct certain social competencies required for the circulation and maximization of wealth. In other words, the humanitarian approach is a form of neoliberal governmentality that entails an expansion of state power to govern and discipline more bodies.

This chapter argues the Compassionate City brand is a form of technology of the humanitarian governance approach at the urban scale. It disciplines the emotions of people by deploying a specific discourse of compassion that is compatible with neoliberalism. Using this analytical lens, the chapter makes three claims on the governance of emotions by Compassionate Louisville. First, it argues that Compassionate Louisville seeks to manage the lives of the precarious population by deploying the new logic that these marginalized communities need to be cared for. However, this logic of care is argued to be exclusionary: it attends to the suffering of certain communities and ignores the sufferings of others. Using the cases of 'compassionate' treatment toward the LGBTQ and homeless population in the city, the chapter critiques that this exclusionary logic of compassion is imbued with neoliberal logic of maximizing wealth: compassion is extended not on the basis of the magnitude of suffering, but on the economic relevance of the communities. Second, this chapter 
argues that Compassionate Louisville acts as a disciplinary apparatus that configures the emotions to make the working population more competent. Analyzing the Compassionate School Project and Mayor's Give A Day program, this section claims that Compassionate Louisville works to engineer self-regulating individuals who are productive, responsible, competent, and morally content with the existing power structure. In other words, Compassionate Louisville helps to socially reproduce the working class. The third argument of the chapter claims that Compassionate Louisville creates the grounds to extract value from the emotions of people. By disciplining the population to be empathetic and generous, the working population is trained to be more efficient, productive, and cheap. Additionally, the engineered imagery and reputation of being a "compassionate" community is also leveraged to gain external investments and tourists. The "Compassionate" community, thus, is itself a form of capital through which economic values can be extracted.

Through these arguments, the chapter makes a broader claim that the discourse of compassion in Louisville does not oppose the ideologies of neoliberalism. Rather, the discourse produced by Compassionate Louisville is complementary to neoliberal ideologies. It acts as a form of neoliberal governmental tool that disciplines emotions to extract more wealth and reproduce a competent and content working population. In simple terms, Compassionate Louisville works the work of capital.

\section{GOVERNMENTALITY AND EMOTIONS}

The term governmentality is coined by the 20th century French philosopher Michel Foucault, by which he refers to a concept of governance that is not limited to state apparatus of laws, but rather a form of power that governs by producing self- 
regulated individuals. In lay terms, governmentality is the mode of governing people through willing participation of the governed. The consent of the people is engineered by instituting certain social rationalities and discourses, which act as 'technologies of self' through which people govern themselves. It is a mode of governance through which the conduct of the people is shaped by manufacturing social truths/rationalities whose compliance results in self-regulated subjects (Foucault, 2010). Foucault writes: "...Governing people, in the broad meaning of the word, governing people is not a way to force people to do what the governor wants; it is always a versatile equilibrium, with complementarities and conflicts between techniques which assure coercion and processes through which the self is constructed or modified by oneself" (Foucault, 1993, 203-204).

According to Foucault, there is a marked shift from the previous organization of power of the pre-modern era where the sovereign monarch could exercise a right over its subject's life and death. In essence, the pre-modern form of governance is tied to the ability of the sovereign to either inflict death or to withhold from killing individuals, and thus it was governance through fear (Nadesan, 2008; Foucault, 1978). However, Foucault argues that as the modern state began to establish in the seventeenth century with the infusion of the ideology of capitalism and liberalism, new rationality of governance developed - that of maximizing the "population wealth." The "population wealth" can be maximized through increasing (a) productivity of the population, and (b) longevity of the productive population. In other words, the wealth of the state can be maximized when the residents are operating in an order that yields optimum productivity and by increasing the durability of residents who are being productive. Therefore, the population came to be viewed as an object to be preserved and increased. The pre-modern sovereign power 
of ruling by fear of taking lives was thus inconsistent with the new rationality of creating and prolonging productive lives. In other words, the state reframed its focus from "take life or let live," to become the power to 'make productive lives' (Foucault, 2003, p. 241). The new modern government interventions, thus, primarily revolve around increasing productivity through dismantling systems that allow citizens to remain outside the circuits of production and instituting public health that seeks to increase vitality, health, and longevity of productive population Nadesan (2008).

Foucault (2007) argues that to achieve these goals, it is necessary for the state to improve and maintain a well-ordered society. This involves adopting new methods for taking control of the population that not only governs the public affairs but also manages the personal affairs at the individual level "in depth, in all its fine points and details" (Foucault, 2007, p. 107). However, the state could not regulate people at the granular level with the disciplinary apparatus of law- the repressive and punitive technology of the law is simply inadequate to govern the private lives of the people (Li, 2007). Instead, this new form of power is increasingly exercised through what Foucault terms "the action of the norm" (Foucault, 1978). This form of power seeks to "“act at a distance' upon the desires and social practices of citizens primarily through the promulgation of...knowledge, experts, and institutions that promised individual empowerment and self- actualization" (Nadesan, pg 27), in order to regulate and produce the life of the population, instead of simply repressing and punishing individuals. To do so, the state resorts to the development of knowledge and technologies that produce certain social rationality, truths, and associated discourses (Foucault, 1983). The domain of the social rationalities and its associated discourse limits and defines the configuration of desires, habits, aspirations, and beliefs of individuals, essentially shaping the conscience of the citizens. The 
engineered conscience of citizens is imbued with ideas of what they are responsible for, the acceptable behaviors, how they should think, and evaluate themselves and others. This consciousness produces self-surveilling and self-regulating citizens $-\mathrm{a}$ form of governance regimes of individuals, what Foucault refers to as governmentality (Li, 2007).

\section{Connecting Governmentality with Emotion}

Emotions as a technology of governance have traditionally received limited attention (D'Aoust, 2014). Foucault himself had little engagement with emotions, and the academic work on governmentality has primarily focused on how the technologies of statistics, economics and public health discipline the body, giving little attention to emotions. However, recent scholars from human geography and cultural studies have argued that emotion is central to the intelligibility of body and hence, management of emotion should also be seen as central to the art of governmentality (For example: Pedwell, 2014; Clough, 2007; Clough, 2008; Anderson, 2012; Hardt, 1999; Ahmed, 2010; Yun, 2010; Schuller, 2018; Gil, 2016; Rutland, 2015; D'Aoust, 2013; Lobb, 2015; Dawney, 2013).

Emotions are often mistakenly viewed as a mere linear response to an event we experience, "...the emotions are viewed as outside the subject and thus acquire a sort of autonomy" (Scheer 2012, 207). On the contrary, emotions produce the boundaries through which we conceive our objective world. We mediate, contest, and consume our world not only through our reason but through our emotions. Seeing from this light, emotions are central to the materiality of bodies and experiences. How we see our bodies and lives is mediated by the emotions we carry, and the emotions projected by others. Specific emotions produce specific effects, specific forms of 
subjective activity, and behaviors. Nelissen et al. (2013), for example, showed that certain emotions, such as guilt, shame, and anger, produce specific normative standards. These examples show that emotions are not an after-effect of an event or experience; rather, it is the very medium through which we make meaning of the event, experiences, and self (Fierke, 2013). In this regard, emotion cannot be disengaged from the relations of power that the notion of governmentality ascribes to because it produces specific materiality, experiences, and social normality, which are central to the management of self-disciplinary subjects (D'Aoust, 2013; Lobb, 2015; Dawney, 2013).

Recent scholarship on the relationship between emotions and neoliberal governmentality (such as Mavelli, 2017; Pedwell, 2014; Clough, 2007; Anderson, 2012; Hardt, 1999; Ahmed, 2010; Yun, 2010; Schuller, 2018; Gil, 2016; Rutland, 2015), thus, claim that the emotional life of individuals and collectives is an object of governance and discipline. This literature argues that certain emotional configuration is required for a capitalist system to extract value, "capital extracts value from affect around consumer confidence, political fears, etc., such that the difference between commodification and labor, production and reproduction, are collapsed in the modulation of the capacity to circulate affect" ( Clough, 2007). In essence, a neoliberal state requires to manufacture and maintain a certain emotional conformation to allow capitalism to do its work (Pedwell, 2014; Anderson, 2012; Hardt, 1999). Additionally, the management of emotion is instrumental for the social production of an efficient working population. As discussed before, emotions mediate the meaning of the world and self. Thus, the induction of social logic such as productivity, longevity, and economic success requires specific emotional settings. In this regard, the management of emotion of the population becomes the object of the 
state regulations. State deploys technologies which guide individuals to experience certain emotions that induce productive activities and inhibits emotions that could produce activity which threatens the neoliberalism (Anderson, 2012; D'Aoust, 2014; Mavelli, 2017; Yun, 2010; Schuller, 2018; Gil, 2016; Rutland, 2015).

\section{Humanitarian Governance}

This section argues that the recent trend of the humanitarian narratives in governance is a technology of governmentality to manage the emotions of the population. Foucault (1977) himself has connected the emergence of these humanitarian sensibilities with circuits of power. Modern humanitarian movements arose in the eighteenth and nineteenth centuries that led to the abolishment of slavery, public execution, and cruelty towards prisoners, animals, and in general human beings. Certain practices and values began to be seen as undeserving suffering. This led to the governmental response of humanitarian reform that delegitimized certain values and practices (Sznaider, 1998). Scholars (such as Haskell 1985; Poovey 1995;

Clark 1997) contend that the humanitarian reforms are a deployment of governmentality whose motive is efficient state control of the population through indoctrination of values and morals that sustain the population wealth.

Recent scholarly debate on humanitarian government is shaped by Didier Fassin who describes it as, "the administration of human collectivities in the name of a higher moral principle which sees the preservation of life and the alleviation of suffering as the highest value of action" (Fassin, 2012: 151). There are three strands of complementary arguments found in the scholarship. The first argument is that the humanitarian government is governance of 'precarious lives' - such as that of marginalized, disfranchised, unemployed, sick, disaster victims and the asylum 
seekers (Reid, 2011; Mavelli, 2017; Ticktin, 2011; Walters, 2010). These scholars argue the humanitarian governance approach deploys a new definition of inclusion/exclusion where care is deployed according to the rationality of 'legitimate' suffering. In doing so, it brings marginalized people under the arch of state governance with the underlying logic securitization and maximization of wealth. The second argument is that the humanitarian governance approach politicizes the suffering of the marginalized while simultaneously depoliticizing and concealing the causes of their suffering. It turns injustice into misfortune, exclusion into unfortunate suffering, and structural violence as individual trauma. In other words, humanitarian governance focuses on the need of the present only, without addressing the historical violence, domination, and deprivation that induces the conditions of the present suffering. In doing so, the humanitarian 'manages' the need of the marginalized and disfranchised communities to the extent it can participate in the circuits of capitalism. However, the state also does not take accountability for the root cause of the problem, denying the marginalized group the right to justice and, most importantly, maintaining the status quo of the power structure of accumulation. As Mavelli (2017) puts it, "Ultimately, humanitarian government entails an expansion and penetration of power as it extends the reach of the state to govern more bodies (e.g., the sick and injured) and more spaces" (pg 811).

The third strand of the argument claims that the humanitarian government is not only about the governance of the marginalized, it also about the governance of emotions of the overall population (Fassin, 2012; Lobb, 2015; Mavelli, 2017; Lyon \& Dolan, 2007; Schuller, 2018). As discussed in the previous section, a certain emotional configuration is required for the reigning political economy of neoliberalism to function and flourish (Clough, 2007; Anderson, 2012). These 
scholarships argue that the humanitarian approach of governance serves the role of managing this very configuration of emotions. For example, Mavelli (2017) contends that the humanitarian narrative of Britain and Germany for accepting Syrian war refugees can also be seen as governmental technology to promote emotional citizenry. In other words, the humanitarian narrative to accept the refugees (read young and skilled workforce that can support the welfare system) was a means to manage the emotional well-being of the citizens of the respective countries.

\section{Compassionate City as Emotional Governance}

This chapter argues that the Compassionate City brand of Louisville is the urban version of humanitarian governance. As described above, the emotional life of an individual and collective is an object of governance and discipline (Mavelli, 2017; Pedwell, 2014; Clough, 2007; Anderson, 2012; Hardt, 1999; Ahmed, 2010; Yun, 2010; Schuller, 2018; Gil, 2016; Rutland, 2015). Seeing from this analytical lens, the Compassionate Louisville brand is a technology of governmentality that is deployed to manage the emotions of the population with the ultimate motive of increasing productivity. It deploys a new logic of emotion that guides individuals to experience certain emotions resulting in conceptions of specific activities. The disciplinary logic of "Compassion" is intimately connected to the rationality of neoliberalism, making the "Compassionate Louisville" brand a technology of overall neoliberal governmentality. Specifically, this section argues that emotional governance through Compassionate Louisville works to (a) manage the precarious population of Louisville, (b) creates emotional competencies of the working population, (c) extracts value from emotions. 


\section{Managing the Precarious Population}

Drawing from the arguments of the humanitarian approach, this section claims that the Compassionate Louisville is a management tool of precarious lives: the marginalized, homeless, unemployed, and disenfranchised community. It does so by deploying a new logic of inclusion/exclusion through acknowledging certain sufferings and discarding other forms. Additionally, it also regulates how to alleviate the acknowledged sufferings, defining what constitutes as legitimate acts of compassion. For example, the city government of Louisville associates the distress of LGBTQ community with the narrative of compassion. The community is extended health, religious, and safety services in the name of compassion. Moreover, in 2020, the Metro Council of Louisville passed a new legislation that will include certified LGBTQ businesses in the city's contracting and procurement opportunities; i.e., the city will not discriminate against businesses based on the gender or sexuality of its owners(!). The lead sponsor of the ordinance, Councilmember Jessica Green claimed it as a compassionate act of the city towards the LGBTQ community, "It doesn't cost us anything to be compassionate and to be business minded. Moreover, it is something we can do today..." (National LGBT Chamer of Commerce 2020) ${ }^{82}$. This infers that the sufferings of the LGBTQ community are acknowledged in the logic of legitimate sufferings deployed by the Compassionate Louisville. On the other hand, the same discourse of compassion excludes the suffering of the homeless population

\footnotetext{
82 "Louisville, KY Passes Ordinance to include Certified LGBT-owned Businesses in City Contracts and Programs," National LGBT Chamer of Commerce, 2020, accessed June 11, 2020, retrieved from: https://www.nglcc.org/press-release/louisville-ky-passes-ordinance-include-certified-lgbt-ownedbusinesses-city-contracts.
} 
of Louisville. As discussed in Chapter 4, the city codes criminalize sleeping in public space after sunset, frequently dismantles homeless camps even during harsh winters, prohibits panhandling on the streets, and allocates insignificant resources in homeless shelters (Costello, 2019) ${ }^{83}$. The discourse of compassion is found to be absent in the homeless population's plight of access to space for survival, seeking shelter against the elements of nature, and even earning an income. Thus, the discourse of the Compassionate City can be argued to be deploying logics that regulate the suffering of certain communities. In other words, it governs a certain segment of the precarious population that is deemed worthy of compassion while ignoring others, creating a regime of segregated humanitarianism.

It can be further argued that beneath this new logic of unequal legitimation of suffering, the rationalities of neoliberalism are at play. In other words, compassion is extended not due to the magnitude of suffering of the communities, but due to the economic relevance of the communities. Take the example of the disparate extension of compassion towards the LGBTQ and homeless communities in Louisville. The LGBT community in Louisville is large in size; according to an estimate, about $4.5 \%$ of Louisville identifies themselves as LGBTQ compared to the national average of $3.6 \%$ (Newport \& Gates, 2015) ${ }^{84}$. This means that the LGBTQ community forms a large segment of the working population in Louisville. To maximize the 'population wealth', this large working population cannot be ignored under the purview of

\footnotetext{
${ }^{83}$ Darcy Costello, " Metro Council passes a safety ordinance that restricts panhandling, but with a few tweaks." Courier Journal

${ }^{84}$ Frank Newport and Gary Gates, "San Francisco Metro Area Ranks Highest in LGBT Percentage." Gallup- Social Policy Issues, March 20 2015, retrieved from: https://news.gallup.com/poll/182051/sanfrancisco-metro-area-ranks-highest-lgbtpercentage.aspx?utm_source=Social\%20Issues\&utm_medium $=$ newsfeed\&utm_campaign=tiles.
} 
governmentality, and hence, various governmental technologies are extended to the community in the name of compassion. For example, the ordinances that provide city contract opportunities can be argued to be governance tools to nudge the LGBTQ towards the circuits of production. Similarly, services such as health, religion, and safety offered to the community in the name of compassion can be argued to be extended for the social reproduction of this working population. In other words, compassion towards the LGBTQ community is extended only because they are an economically relevant working population, whose productivity and longevity increase the 'population wealth.' On the other hand, the homeless population, who does not see the light of compassion, is a comparatively smaller population (about 7000 in 2018 according to the survey of Coalition for the Homeless) and largely operates outside the circuits of capitalism. The homeless population does not own property, often do not have formal employment or do not qualify for employment, and rely on noneconomic transactions such as panhandling for livelihood. This community, thus, is economically less relevant as a working population and thus, can be considered as disposable. In this regard, despite the homeless community experiencing much graver suffering which often culminates to death, the logic of compassion deployed by the city excludes them. Seeing from this lens, it can be argued that Compassionate Louisville deploys an exclusionary logic that extends support towards specific precarious communities and this logic of inclusion/exclusion is mediated by the neoliberal governmental rationality.

\section{Creating Emotional Competence}

This section argues that Compassionate Louisville works to discipline citizens at the emotional level through managing a configuration of feelings that results in 
productivity. The discourse of compassion, produced by the city brand, propagates a certain emotional setting - that compassion is honorable, apolitical, and holds the moral authority of the highest standard. It also produces a logic that compassion is a skill that can be and should be learned to be competent. The discourse promotes the idea that individuals have a role in addressing social crises that plague the city. In doing so, the discourse plays a part in governing the emotions of the people of Louisville- regularizing the feeling of empathy and care for others as a moral responsibility of every individual. In addition to the discourse of compassion, Louisville has two specific programs that act as tools of emotional governance: The Compassionate School Project that produces emotionally self-regulated students (future working force) and Mayor's Give A Day program that serves to produce emotional contentment for adults.

The Compassionate School Project of Louisville can be argued to be a technology of emotional governance of children that aims to create self-disciplining individuals. The Project, which is partnered by the Jefferson County Public Schools, Louisville Metro Government, and the University of Virginia, is celebrated as the "the most comprehensive study ever undertaken by a 21 st century health and wellness curriculum in an elementary or secondary school setting" (Compassionate School Project, 2016) ${ }^{85}$. Currently, the Compassionate School Project is active in 45 schools under the Jefferson County Public Schools (JCPS) system comprising over 20,000 students. The Project integrates instruction on mindfulness, social-emotional skills, and nutrition into the curriculum of elementary and secondary schools to develop 'compassionate characters' in students. The Louisville Metro Government claims that

\footnotetext{
85 “Program," Compassionate School Project, 2016, accessed June 11, 2020, retrieved from: https://www.compassionschools.org/program/.
} 
the aim of the Project is to improve the "behavior" and academic performance of the students (Louisville Metro Government, 2016) ${ }^{86}$. According to the project website, the Compassionate School Project's philosophy involves:

"Educating the whole child for self-awareness and self-understanding, the curriculum integrates mindfulness for stress management and self-control; contemplative movements, postures and breathing for physical awareness and agility; nutritional knowledge for healthy eating; and social and emotional skills for effective interpersonal relationships. Elementary school students will learn to cultivate focus, resilience, empathy, connection, and wellbeing as the basis for academic and personal success" (Compassionate School Project 2016) ${ }^{87}$.

Seen through the lens of emotional governance, the Compassionate School Project of Louisville can be argued to be disciplining the emotions of the children at the school level. The claim that the school system is a disciplinary apparatus is not new. Researchers on power and school systems equivocally argue that schooling is a technology of control to create self-regulating subjects (Mitchell \& MacFarlane, 2019; Besley, 2005; Anderson \& Grinberg, 1998; Ryan, 1991). In the case of the Compassionate School Project, this disciplining apparatus adds the dimension of emotional skills such as "mindfulness," "focus," and "resilience" (Compassionate School Project, 2016) ${ }^{88}$. These emotional skills which are dubbed as "wellbeing" can also be read as the development of competencies required for the employment market: mindfulness can be transposed as social skills, the focus can be translated as a determination for success, and resilience can be explained as skills of adaptability. The Compassionate School Project, thus, instills a certain configuration of emotional

\footnotetext{
86 "Compassionate Schools Project announces program fully under way; grants totaling \$4.4M," Louisville-Jefferson County Metro Government, October 6, 2016, accessed June 11, 2020, retrieved from: https://louisvilleky.gov/news/compassionate-schools-project-announces-program-fully-underway-grants-totaling-44m.

87 "Program," Compassionate School Project, 2016

${ }^{88}$ Ibid
} 
settings that can be argued to be compatible with the political structure of neoliberalism. It disciplines the emotions of the next generation of the population who would be more resilient, more socially skilled, and more determined for success. In other words, the students are being trained in emotional competencies required to be a more productive future workforce. It also instills individual responsibility of health and emotional wellbeing in the mind of the students at a very early stage- inducting the rationality of longevity of the population. Most importantly, in the name of emotional wellbeing, it guides students on which emotions to acknowledge and how to acknowledge those emotions. It also escorts how to feel emotions regarding themselves, others, and overall society which creates a version of social truths that forms the basis of their ontological position. This creates self-disciplining individuals who feel a certain way and thus behave in a certain way- a mode of disciplining and control. This reading of the Compassionate School Project is not a stretch of the concept of governmentality. JCPS itself claims that production of self-disciplining individuals is one of the core success parameters of the Compassionate School Project; the Superintendent, Dr. Donna Hargens, while claiming the success of the project notes, "While these non-cognitive skills won't show up on standardized tests, they are increasingly vital to our students' academic success by building capacity within themselves to self-regulate and make great choices" (Jefferson County Public Schools, 2016) ${ }^{89}$.

As Compassionate School Projects can be argued as emotional governance of the children, the Mayor's Give A Day (MGAD) program can be argued as tools of

\footnotetext{
89 “Compassionate Schools Project Announces Four Major Grants Totaling \$4.4M \& Launch of Full Implementation,” Jefforson County Public Schools, October 5, 2016, accessed June 11, 2020, retrieved from: https://www.jefferson.kyschools.us/departments/communications/monday-memo/compassionateschools-project-announces-four-major-grants.
} 
emotional disciplining adults. As discussed in Chapter 4, MGAD facilitates volunteering opportunities to the residents of Louisville in different social projects such as building beds for schools, cleaning neighborhoods, donating blood, and planting trees. In 2019, about 205,000 people volunteered 327,699 total hours (about 1 hour and 35 minutes person) that resulted in achievements such as 158 beds built for JCPS, 198 units of blood donations, $\$ 800$ raised (!) and clean neighborhoods (Louisville-Jefferson County Metro Government, 2019) ${ }^{90}$. The city government defines these "one day" of volunteering as "selfless: acts of compassion through which people fulfill their "social responsibility."

However, recent scholars (such as Vrasti \& Montison, 2014; Griffiths \& Brown, 2017; Gabriel, 2020; Dean, 2015) have argued that voluntarism is less about selfless compassion, social responsibility, or even fulfillment of personal emotions. Instead, voluntarism is more aligned with the injunction of market rationality and social responsibility that seeks to creates subjects "responsible for its own skills and assets" (Vrasti \& Montison, 2014). They further argue that emotional skills are seen as desirable traits by many employers which incentivize individuals to volunteer for social work as a means to acquire emotional competencies required for individual success. In other words, volunteerism intricately plays a part in indoctrinating market rationalities in the emotions of the individuals. Seen from this perspective, Compassionate Louisville's MGAD program can be read as a platform to acquire necessary social skills. The website of Metro United Way actively uses the language of skill development to attract volunteers for MGAD, "Who knows, you might find or

\footnotetext{
90 "Mayor rallies community for eighth annual Give A Day Week of Service," Louisville-Jefferson County Metro Government. 2019.
} 
learn skills you never thought you had" ${ }^{91}$. In other words, the MGAD is positioned to volunteers as a means to acquire new skills.

Additionally, MGAD can be argued to leverage the emotions of compassion to make people of Louisville perform works unwaged that the government should have managed. In rallying for the MGAD in 2015, Mayor Fischer urged, "We're all busy, but to be good people and good citizens we should make time to help others and improve their lives and our community" (Louisville-Jefferson County Metro Government 2015) ${ }^{92}$. This statement indicates that working as a volunteer makes "good people" and "good citizens". In other words, to be a "good person", one needs to work unwaged on one of the MGAD projects. Such notions responsiblizes individuals for social services and welfare while dismantling the idea that such welfare and services should be delivered by the city government.

MGAD can also be read as emotional management of the people to be affective, sensitive and content. Along with the above quote that states volunteering in MGAD makes good people and citizens, the event is also frequently associated with a congratulatory narrative for making significant changes in society. For example, in 2016 Mayor Fischer stated that MGAD creates social connectedness and solidarity,"That is what Give A Day is all about - making connections and helping individuals recognize our interconnectedness" (Louisville-Jefferson County Metro

\footnotetext{
91 "Give A Day and Get a Lifetime of What It Feels Like to Make a Difference," Metro United Way, accessed May 20, 2020, retrieved from: https://metrounitedway.org/join-us-in-the-fight/volunteer/ 92 "Mayor Rallies Community for "Give A Day" Week of Service," Louisville-Jefferson County Metro Government, March 10, 2015, accessed May 20, 2020, retrieved from: https://ouisvilleky.gov/news/mayor-rallies-community-give-day-week-service-april-18-26.
} 
Government 2016) ${ }^{93}$. On a similar tone, one of the volunteering church of MGAD stated in 2019, "It's good to see happy faces and people that are getting something that can be a life-changing event for them" (Wagner 2019) ${ }^{94}$. Such congratulatory narrative associated with MGAD nudges volunteers to picture themselves as alleviating others' suffering, being 'compassionate' individuals and more importantly being "good people". In doing so, people are made to feel they are being part of solving social problems and fulfilling their responsibility to the community. This helps to manage the emotion of the community, instilling a feeling of being responsible individuals who commit to the distress of the society and providing moral contentment. MGAD, therefore, can be seen as an emotional regulatory technology creating a responsible, morally content, and socially skilled population required for the circulation and maximization of wealth.

\section{Compassion as Capital: Extracting Value through Emotions}

Along with extortion from labor, Compassionate City also extracts value through the very image of being a "Compassionate" community, by attracting external investments and tourists. Recall that city branding is primarily a policy instrument to make cities economically relevant to gain a competitive advantage in the intercity capital market (Pasquinelli 2010; Eshuis and Edwards 2013; Johansson 2012; Kavaratzis \& Ashworth, 2009; Lyles, et al., 2018). In Louisville, it does so by

\footnotetext{
93 “Give A Day Week Impacts Louisville With 175,000 Volunteers, Acts of Compassion,” LouisvilleJefferson County Metro Governmen, April 27, 2016, accessed May 20, 2020, retrieved from: https://louisvilleky.gov/news/give-day-week-impacts-louisville-175000-volunteers-acts-compassion. ${ }^{94}$ Sara Wagner, "Give A Day Impact: Pedal Power." WHAS11, April 10, 2019, retrieved from: https://www.whas11.com/article/news/give-a-day-impact-pedal-power/417-1575920a-5483-47a7-87cf0597a794405f.
} 
governing the emotions of the population to guide them into a certain configuration of affective state. In other words, the Compassionate City brand helps to manufacture a favorable image of being collectively caring, emotional, empathetic and altruistic. An interviewee ${ }^{95}$, who worked for the Charter of Compassion and helped Louisville to become the signatory of the Charter, claims that the Compassionate City is a great marketing technique to gain international attention: “Oh, it's a superb PR thing, especially when there is suspicion of government generally among people, especially in conditions now. And it drew the Dalai Lama here. That was a big PR piece, the Association of cities, whatever, they really featured it to showcase." This positive imagery of the city creates what the scholars of Marketing call a "Brand Equity"96 - an additional value of the reputation of the brand that can be monetized. This reputation is then sold in the market to attract investments and tourists. Seeing from this light, Compassionate City works to govern the emotions of its population to sell the brand equity it produces. The more emotionally disciplined the population is, that is the more people act compassionately, the greater the perceived brand equity of the city and consequently the higher the marketability of city. In other words, the emotionally disciplined "compassionate" population is an asset for the city that can be leveraged in the market to increase wealth.

There is evidence that Louisville packages this manufactured favorable image to attract investments. An interviewee ${ }^{97}$, who works closely with the city government

\footnotetext{
95 Please see the Appendix F for transcript of the interview.

96 The concept of Brand Equity refers to the total value of a brand as a separable asset that is generated due to the positive image in the mind of the consumers. It is a measure of the strength of reputation of the brand in the mind of the consumers. In corporate business ecosystem, the Brand Equity is often included on a balance sheet as monetized and transferrable asset (Wood, 2000; Feldwick, 1996) 97 Please see the Appendix F for transcript of the interview.
} 
for the Compassionate City initiatives, claims that Louisville attracts businesses to relocate to the city using the image of compassion: "Businesses which have relocated, at least anecdotally, have told the mayor's office that part of why they wanted to be in Louisville was the community's commitment to compassion." On a similar note, the Mayor in an interview claimed that Computershare ${ }^{98}$, an Australian based financial company, chose to locate in Louisville because of its image of compassion, "I asked the CEO of Computershare what made the difference between his company choosing us or the other finalist city when deciding where to locate his business and 250 jobs. He said one reason they chose Louisville is that they liked our city's focus on compassion" (Klayko, 2016) ${ }^{99 .}$ These examples show that the Compassionate City makes the image of being a "compassionate" community a competitive advantage to attract external capital in the city.

98 Computershare is Australian stock transfer company that provides corporate trust, stock transfer and employee share plan services in a number of different countries.

99 Branden Klayko, "Interview: Mayor Greg Fischer on what Louisville does right.” Broken Sidewalk, February 10, 2016, retrieved from: https://brokensidewalk.com/2016/greg-fischer-interview/ 


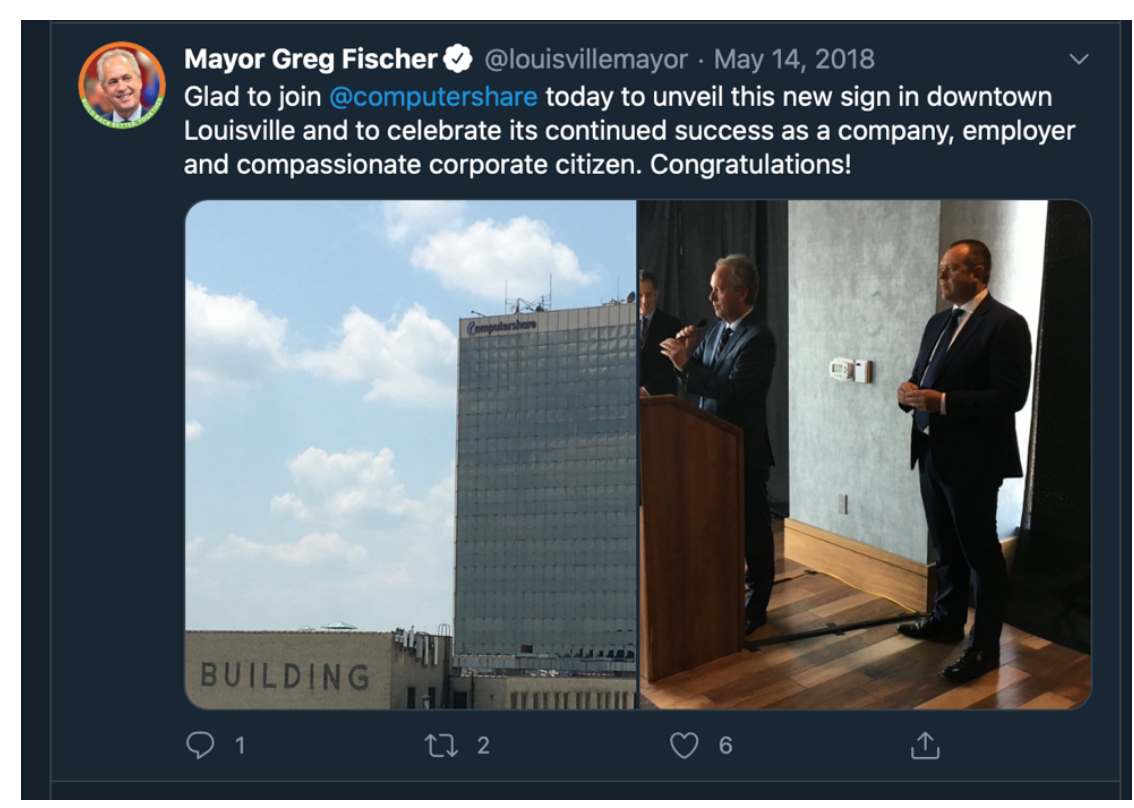

Figure 2: A screenshot of the tweet of the Mayor of Louisville welcoming Computershare

Along with attracting capital, the image of the Compassionate City is also leveraged to attract tourists. According to a report by Kentucky Tourism, in 2016 Louisville earned \$3.5 Billion from tourism activity (Kentucky Tourism, Arts and Heritage Cabinet, 2017). While much of the tourism in Louisville can be attributed to the Kentucky Derby and Bourbon, the city also heavily uses the narrative of compassion to market itself to tourists. For example, the official website of the city that promotes tourism, gotolouisville.com, describes itself as: "Louisville: A Compassionate City. Welcome to Louisville - a city touted around the globe for its compassion" (Go To Louisville, n.d.) ${ }^{100}$. Recently, the city government also ran a marketing campaign on its official social media accounts (Twitter and Instagram accounts) stating that Louisville is lighting up some of its tourist attractions with green lights to "symbolize compassion for all the COVID-19 victims".

100 “International Welcome," Go To Louisville 
These examples of targeting external investment and tourism show that Compassionate City extracts value from the imagery of being a "Compassionate" community. It can be argued that the altruistic, benevolent, empathetic people produced through the emotional governance are itself productive assets- a form of capital from which wealth can be generated. Compassionate City, therefore, is a form of neoliberal governmental technology that disciplines people to generate an emotional setting through which capital can be expropriated.

\section{CONCLUSION}

Playing the devil's advocate, it can be argued that the discourse of Compassionate Louisville is not potent enough to be the dominant logic that governs the emotion of people and create self-regulated subjects. People do not simply become altruistic just because the city government has started to call itself "Compassionate." Instead, the discourse of compassion can be seen as empty political rhetoric and, thus, the claim that the logic of compassion disciplines people's emotions can be argued to be a stretch. Instead, Louisville's dominant logic is still cold and calculated reasoning of neoliberalism, which is evident in its insignificant resource allocation for social welfare, its focus on attracting external capital, and commitment to create an enabling environment for capitalism to perpetuate.

However, such an argument assumes that the discourse of compassion is incompatible and in opposition to the dominant ideology of neoliberalism. On the contrary, this chapter shows that the discourse compassion, in the manner used in Louisville, is not designed to be the dominant ideology. Regardless of the moral loftiness of compassion, it is neither in opposition to the ideology of neoliberalism nor a replacement. Rather, Compassionate Louisville is another face of neoliberalism - 
that is not only complementary to each other but also is imbued and originates from the very neoliberal logic of perpetuating wealth.

This chapter claims that Compassionate Louisville acts as a tool of neoliberal governmentality that disciplines people's emotions to develop a more efficient working population and extract more value. The arguments of this chapter are based on the literature that connects emotions and neoliberalism: a certain set of emotional configurations is required for the neoliberal political economy to be meaningful, acceptable and legitimate. In other words, the development of a specific emotional economy is integral to social relations required by neoliberalism and capitalism to function. As D'Aoust (2014) states, "the market's own 'machine of seeing' is inextricably linked to a machine of feeling as well." Emotions, therefore, become an object of governance, that is achieved by deploying governmental technologies that guide individuals to experience certain emotions that are 'productive' while inhibiting emotions that are threatening to circuits of production. The recent trend of humanitarian governance that takes the narrative of care and compassion is argued to be one such approach to discipline the emotion of the population. It serves the role of managing the configuration of emotions of individuals to induct certain social competencies required for the circulation and maximization of wealth.

Using this analytical lens, this chapter argues that Compassionate Louisville is a form of humanitarian governance- a tool of neoliberal governmentality that disciplines people's emotions. First, the chapter argues that Compassionate Louisville serves to manage the precarious population of Louisville by deploying an exclusionary discourse of care where compassion is extended on the neoliberal logic of economic relevance. Second, the chapter claims that Compassionate Louisville works to instill emotional competencies in the working population to be more 
productive and morally content. In essence, Compassionate Louisville helps in the social reproduction of the working population who feels in a certain way and thus behaves in a certain way- to be productive, responsible, and content with the existing power structure. The third argument of this chapter claims that Compassionate Louisville governs the emotion to transform people into productive assets through which economic values can be extracted. In other words, the "Compassionate" community is itself a form of capital through which values can be expropriated.

These analyses shed light on Compassionate Louisville as a technology of subjectification and control. The brand of Compassionate Louisville is not a simple, straightforward marketing strategy of the city; instead, it is a potent apparatus of neoliberal governmentality. Behind its veil of humanitarianism, Compassionate Louisville works the work of capital. It is an extension of overall neoliberal governmentality that seeks to discipline the emotion of people to increase productivity and extract more wealth. It creates new forms of subjectivity and deploys an even stronger form of control that regulates not only the "mind" of individuals but also their "hearts". 


\section{CHAPTER 6 - CONCLUSION}

Before reiterating the critique of the discourse produced by Compassionate Louisville, lets fully acknowledge the contribution the brand has brought in the city. The brand of Compassionate Louisville frames the city with a reputation of having a culture of benevolence and compassion, which plays a role in attracting tourists and investors. It has established a culture of volunteerism through Mayor's Give A Day Event that provides citizens a platform to volunteer in various social projects. It popularized the values of inter-faith harmony. It encourages religious organizations, non-profits, and businesses to take up social projects targeting alleviation of people's suffering. Most importantly, it has brought public attention to the alleviation of suffering in the city. This dissertation, however, is not a congratulatory thesis of Compassionate Louisville. Neither is it about an assessment of how "compassionate" the city is. Instead, this dissertation seeks to understand the latent ideology of the discourse produced by the brand of Compassionate Louisville.

The overall objective of the dissertation is to investigate what the "Compassionate City" tag of Louisville does. Recent research by Ruez \& Parekh (2019) claims that the image of Compassionate Louisville can be best understood "in relation to its politics, rather than either the benevolent intentions of its proponents or to theoretical frames that reduce compassion to a singular logic to be critiqued." In other words, they postulate that Compassionate Louisville needs to be comprehended not in terms of how much "compassionate" Louisville is, but how the narrative of compassion is connected to the politics of the city. This dissertation, therefore, seeks 
to understand Compassionate Louisville in relation to its politics. To be specific, the dissertation aims to critique what the discourse produced by Compassionate Louisville does in the politics of the city: what it claims, what it produces, and what kind of governance regime it enacts. There are three specific but interrelated findings of this dissertation:

1. Compassionate Louisville is a city brand that influences the politics of the city by generating a discourse of compassion (Chapter 3 )

2. The discourse of compassion in Louisville is intimately connected to neoliberalism (Chapter 4)

3. Compassionate Louisville is a tool of neoliberal governmentality that disciplines the emotions of people (Chapter 5)

\section{COMPASSIONATE LOUISVILLE: A CITY BRAND}

Before we can understand what "Compassionate Louisville" does, we must first come to terms with what "Compassionate Louisville" is. Research of Ruez \& Parekh (2019) gives a hint to answering this question when they ascribe Compassionate Louisville as imagery. As Chapter 3 shows, Compassionate Louisville is not a city-funded program or a department; it does not have any concrete goals, measurable targets, or a single line of budget allocation. It is neither a measure of an individual benevolence of the city, nor does it involve an institutional approach of having specific policies to address suffering. Instead, "Compassionate Louisville" can be best described as an aspiration of what the city wants its identity to become, a portrayal of an image to its residents and to its external stakeholders to be empathetic, benevolent and moral - an image engineering that is usually associated to city branding. 
City branding is typically described as an entrepreneurial governance approach that seeks to create a favorable image to attract investors, tourists, and new residents (Eshuis \& Edwards, 2013; Pasquinelli, 2010; Johansson, 2012). Chapter 3 provides evidence that indicates Compassionate Louisville serves this role. The image of being a "compassionate", "benevolent," and "empathetic" community is often packaged as a competitive advantage to attract new investments. Moreover, Louisville heavily uses the language of "compassion" in tourism marketing to attract international and national tourists. These indicate that the "Compassionate Louisville" is indeed a city brand- an image engineering for external stakeholders.

However, chapter 3 also argues that seeing the "Compassionate Louisville" brand as just a selling tactic to the external market ignores its influence within the local politics. Instead, Compassionate Louisville has significant influence on city politics. It generates a discourse that positions individual compassion as spiritual, honorable, and apolitical. Compassion acts are glorified as benevolent, altruistic and moral. In doing so, the discourse of compassion in Louisville propagates the idea that much of the social problems that plague the city can be resolved by individual compassionate behavior. This discourse of compassion is increasing being a key logic in mediating, claiming and contesting debates in the politics of Louisville. The narrative of compassion is frequently evoked in planning documents as a vision of Louisville, including in the recent long-term strategic plan which states, “In 2040, Louisville Metro is a vibrant and diverse community that is connected, healthy, authentic, sustainable and equitable, with compassionate citizens ..." (LouisvilleJefferson County Metro Government 2019, pg 31) ${ }^{101}$. The language of compassion is

101 Louisville-Jefferson County Metro Government, Plan 2040: A Comprehensive Plan for Louisville Metro 
also used in mission statements of various city government departments such as that of the Department of Emergency Services (Louisville-Jefferson County Metro Government n.d. $)^{102}$, and the Department of Resilience and Community Services (Louisville-Jefferson County Metro Government n.d.) ${ }^{103}$. The archive analysis of the meeting minutes of the Metro Council shows that the discourse has been used in last decade in a wide range of political debates including that of fiscal budget, minimum wage, public safety, economic development, homelessness, affordable housing, health equity, sanctuary city, animal rights, parks, cannabis legalization, and coronavirus response. These examples show that the Compassionate Louisville is not politically mute; instead, the discourse of compassion is increasingly being one of the logics of political debates that shapes planning, policy-making, and overall politics of Louisville.

Additionally, the discourse of compassion is actively used by citizens to make political claims in a wide range of issues such as LGBTQ rights, racial justice, homelessness, immigrant rights movement, and abortion rights activism. These citizen-led activisms that have a presence in almost all US cities typically make their claims on the grounds of rights, freedom, and justice. However, chapter 3 shows that these same political struggles in Louisville have used the discourse of compassion either in conjunction with or even given higher weight over their usual logic of rights and justice. Occupy ICE of Louisville, for example, called their protests as "Camp Compassion" (Meador 2018) ${ }^{104}$ and claimed that it is "compassionate" to provide a safe space for immigrants despite their legal residency status. The LGBTQ activisms

\footnotetext{
102 “Emergency Services - Our Mission”, Louisville-Jefferson County Metro Government

103 "Resilience and Community Services Overview," Louisville-Jefferson County Metro Government

104 Jonathan Meador, “Encampment aims to ‘Abolish ICE,' pressure mayor.” Insider Louisville
} 
in support of the community have been infused with that of the narrative of compassion, calling the annual pride parade event as "Colors of Compassion". The Black Lives Matter evokes the narrative of compassion through their argument that Louisville cannot be compassionate until it addresses racial police violence and incarceration (Leonard 2018) ${ }^{105}$. On a similar note, the activists who protest against dismantling homeless camps argue that displacing the homeless without offering an alternative solution is contradictory to the notion of compassion (Ratterman \& Corsey 2019) ${ }^{106}$.

The use of the language of compassion by various social actors in Louisville to make political positions shows that "compassion" is becoming a new political logic. The discourse of compassion may not be the dominant political logic of Louisville. However, the chapter shows that the discourse is gaining popularity as a political logic through which debates are mediated. This indicates that the brand of Compassionate Louisville is not a mere docile slogan; instead, it has a political agency of creating new logic through which political debates are negotiated, contested, and accepted.

\section{CRITIQUES OF THE DISCOURSE OF COMPASSIONATE LOUISVILLE}

While the discourse of compassion arguably has a political agency in Louisville, Chapter 4 argues that compassion is not necessarily an elixir to address the city's social problems. The chapter critiques discourse of compassion and the use of its logics do in Louisville. It argues that the discourse aids neoliberalism in Louisville

\footnotetext{
105 Connie Leonard, "Protesters demand accountability after officer-involved shootings." Wave3 News ${ }^{106}$ Lexie Ratterman and Gilbert Corsey, "Homeless forced to relocate as Louisville cleans out camps." $W D R B$
} 
by privatizing the responsibility of welfare in the disguise of a moral high ground of compassion. In the process, it depoliticizes social problems, displaces rights, and entrenches existing precarity in the city.

The discourse of compassion in Louisville propagates the idea that the virtue of individual compassion is not only moral virtue that everyone should have but it is also the solution to the social issues of the city. Louisville is plagued with chronic social problems of inequality, poverty, homelessness, health disparity, and racial segregation. Chapter 4 critiques the discourse of compassion with the claim that virtue of individual compassion cannot and does not address these social issues; rather, the narrative of compassion helps to produce and reproduce the asymmetries of Louisville in the disguise of solving them. It argues that the discourse of compassion shifts the responsibility of issues of welfare provision, distributional equity, and social justice away from public affairs to private affairs. However, individual compassion alone is inadequate to address the social problems of Louisville, largely because these issues are perpetuated by structural circuits of global capital and its perverse relationship with both local and federal governments. In other words, social issues produced by large structures cannot simply be addressed by acts of individual compassion without the government taking responsibility. More importantly, the pushing of the responsibility of addressing the suffering to the compassion of individuals is an act of depoliticization of social issues. It helps the city government of Louisville to wash its hands off from the responsibility of delivering welfare and social justice. Rather, it is the individuals who are responsible for taking care of the distressed through philanthropy.

The discourse of compassion arguably displaces the rights of the marginalized community. The chapter shows that the discourse of compassion tends to divide 
society into two groups: one that comprises of people who are seen as weak, suffering, objects in need help; and the other group of powerful, wealthy, and philanthropic. The act of compassion is an act where the second group bestows kindness on the first group to alleviate their suffering. This logic, however, ignores the political right of the marginalized communities - that their suffering should be addressed not out of the mercy of someone but because of their right as a citizen. In other words, marginalized communities are being treated as voiceless victims who have no social rights to the alleviation of their suffering.

Chapter 4 also argues that the logic of compassion is inconsistent to the notion of justice. Compassion is, by definition, voluntary: individuals cannot be legally or morally held accountable to be kind to one another, to give charity, or to alleviate the sufferings of others altruistically. Putting the responsibility of social issues on the compassion of individuals, thus, leaves marginalized communities in a state of precarity where they do not have any guarantee of alleviation of their suffering. In other words, it dismantles the notion that issues such as marginalization, poverty, inequity, and suffering are a matter of social justice that calls for collective and institutional actions. Rather, the relief from distress is dependent on the benevolence of the privileged who may or may not extend their compassion.

Taking these arguments together, the chapter claims that the discourse of compassion aids further entrenchment of neoliberalism in Louisville. Through the logic that responsiblizes individuals to address the social problems through acts of compassion and philanthropy, the discourse of compassion allows the city government of Louisville to waive its own responsibility of attending to the suffering and marginalized community. Such an approach of "rolling-up" the responsibility of the government for welfare provision to individuals and business actors is a trademark 
neoliberal strategy. In other words, the new logic of compassion that the brand of "Compassionate Louisville" produces is complementary to the neoliberal political economy.

\section{COMPASSIONATE LOUISVILLE AS A TOOL OF EMOTIONAL DISCIPLINING}

The third key finding of this dissertation is that Compassionate Louisville is a tool of neoliberal governance that disciplines the emotions of the people. Recent scholars ${ }^{107}$ of Human Geography and Cultural studies argue that emotions are integral to social relations required for the perpetuation of neoliberalism. A certain set of emotional configuration is necessary for the neoliberal political economy to be meaningful, acceptable, and legitimate. In this regard, this branch of scholars argues that emotions are often taken as objects of neoliberal governance- disciplining people on how they should feel, process and act on emotions. In other words, individuals are guided to experience certain emotions that are "productive" while inhibiting emotions that are threatening to circuits of productions. The recent trend of humanitarian governance, which is subsumed with the narrative of caring for the distressed and empathy towards suffering, is argued to be one such approach to discipline the emotion of the populations.

Chapter 5 claims that the Compassionate Louisville brand is an urban version of humanitarian governance whose actual motive is to discipline the emotion of the

\footnotetext{
${ }^{107}$ For example: Pedwell, 2014; Clough, 2007; Clough, 2008; Anderson, 2012; Hardt, 1999; Ahmed, 2010; Yun, 2010; Schuller, 2018; Gil, 2016; Rutland, 2015; D'Aoust, 2013; Lobb, 2015; Dawney, 2013
} 
residents of Louisville. The chapter makes three arguments to support this claim. First, the narrative of Compassionate Louisville seeks to manage the precarious population of the city: the lives of the marginalized, disfranchised, and suffering communities. Comparing the cases of the LGBTQ community and the homeless population, the chapter shows that Compassionate Louisville deploys an exclusionary logic that cares for the sufferings of specific communities (LGBTQ) and ignores the distresses of others (homeless). This exclusionary logic is imbued with the neoliberal principle of maximizing wealth: compassion is extended not on the basis of the magnitude of suffering of the communities, but on their economic relevance to the city.

Second, the Compassionate Louisville disciplines the emotions into a configuration that results in self-regulating individuals who are productive, competent, and morally content. To explain this point, the chapter analyzes two initiates of Compassionate Louisville- the Compassionate School Project and Mayor's Give A Day program. The former trains elementary and secondary school students to guide them on which emotions to acknowledge and how to feel emotions in relation to themselves, others, and overall society. The latter is targeted towards the working population to instill an orientation of responsibility, productivity, and moral contentment. In both cases, Compassionate Louisville serves the work of neoliberalism to create self-disciplining individuals who feel in a particular way and thus behave in a certain way- to be productive, responsible, and morally content with the existing power structure.

The third point argues that Compassionate Louisville governs the emotion of the population to transform it into productive assets through which economic values can be extracted. By disciplining the population to be affective, empathetic, and 
generous, the working population is trained to be more efficient, productive, and cheap. Additionally, the engineered imagery and reputation of being a "compassionate" community is also leveraged to gain external investments and tourists. The "Compassionate" community, thus, is itself a form of capital that expropriates value.

These arguments point out that the discourse of compassion in Louisville is not only complementary to neoliberalism but also imbued and originates from the very neoliberal logic of perpetuating wealth. Compassionate Louisville, therefore, is argued to be an extension of neoliberal governmentality. Behind its veil of humanitarianism, the discourse of compassion creates new forms of subjectivity and regulate emotions to increase productivity and extract more wealth.

\section{IMPLICATIONS}

In a nutshell, the findings of the dissertation show that Compassionate Louisville is an imagery- a brand that generates a political discourse of compassion. This discourse is increasingly becoming a new narrative in making political claims. However, behind the moral loftiness of compassion, the discourse serves the logic of neoliberalism. It shifts the responsibility of addressing social problems from the city government to individuals. More importantly, it creates new forms of subjectivity that regulate people's emotions in order to extend neoliberal governance.

These findings are contextually unique and should only be understood in the socio-political context of Louisville. In other words, the findings cannot be extrapolated to other forms of city branding, even those that label themselves "Compassionate city." Each case of image engineering should be studied in the specific context it originates and operates (Jokela 2020). However, contextuality does 
not render the findings to have fewer implications. Instead, the contextual knowledge generated in this dissertation, by itself, should be treated as an important implication. It helps to explain a key moment of Louisville's politics, where the image of the city started to become relevant in policies, planning, and governance. Moreover, the contextuality does not limit the findings to be connected with broader scholarships. This section outlines three ways the findings open up new discussions in Urban Studies.

First, the findings contribute to establish a relationship of city branding with local politics. Quite often, city branding is theorized in a manner that reduces it to logos, slogans, or marketing campaigns. Such conceptualization takes city branding as a politically docile marketing strategy. Recent scholarships, however, have argued that city branding can be more than that; it can be a "holistic urban policy" that provides direction towards policies, administrations, and overall governance (Joo and Seo, 2018: 240; Lucarelli, 2018). Jokela (2020) has further connected city branding with the "production of new urban subjects" (pg 2042) with attributes desirable by the neoliberal governance. The dissertation contributes to this reconceptualization of city branding as a potent technology of governmentality that can govern the behavior of citizens and, in the process, effect local politics.

The dissertation shows that a city brand of Compassionate Louisville is not produced in a political vacuum; rather, the image of the city is manufactured in conjunction with its citizen. It requires sustained multi-lateral politicking through which the city image is negotiated, formed, and maintained. This politicking to produce and maintain the brand involves manufacturing a political discourse of compassion. The discourse forms a certain social logic that guides how the citizens should think, act, and be. It can shape the meaning of what the city stands for and 
influence its policies, planning, contestation, and negotiations. It enrolls the citizens in the domain of social rationalities that can influence, control, and govern their behavior.

These findings contribute to the reconceptualization of city branding as a potent tool of governmentality. It opens up a new understanding of city brands, where it is not only seen as an image-making process to market to external investors and tourists. Instead, city branding can also be viewed as a tool that can generate new discourse and, in the process, influence local politics. It can be a governmental apparatus that can produce social rationalities, guide actions, and discipline thoughts of people to become self-regulated citizens. In other words, the findings of this research indicate that community image-making is a complex tool of power.

Second, the dissertation opens the discussion about emotional management at the urban scale. There is a small literature on disciplining of emotion under neoliberal governance. This literature argues that the development of a specific emotional configuration is integral for neoliberalism to function and be acceptable. Management of emotions, therefore, becomes an object of neoliberal governance. However, this literature primarily focuses on humanitarian governance at the national and global scale- working on issues such as refugee crisis, international migration, foreign aid, and overall global capitalism. While these issues are relevant, there is no scholarship that investigates the emotional governance at the urban scale or through an apparatus like city branding.

The finding of this dissertation shows that Compassionate Louisville governs the emotions of the people of Louisville. It disciplines the working population to feel in a certain way and thus behave in a certain way- to be productive, responsible, and content with the existing power structure. It also creates an urban emotional economy 
where emotions are transformed into productive assets through which economic values can be extracted. These findings open the discussion on how urban neoliberal governance disciplines the "heart" of the city. It exemplifies that urban neoliberal governance is not only about cold economic reasonings, it also entails emotional subjectification of the residents of the city.

Third, the findings of this dissertation point that the discourse of humanitarianism should be understood in its political relations. Quite often, the humanitarian narratives are subsumed with morally lofty ideals such as care for the sufferings, empathy, philanthropy, altruism, or responsibility towards the marginalized. They are seen as positive virtues that are associated with higher moral standards. Compassion, for example, holds the meaning of empathizing the suffering of another and altruistically helping people out of their misery. However, the dissertation shows that the discourse compassion in Louisville, when analyzed with the urban political context it is entangled in, is not necessarily a benign ideal or virtue. Instead, the discourse of compassion is used to justify the privatization of welfare, depoliticization suffering, and the displacement of the marginalized community's political rights to demand alleviation of their distress. In other words, the discourse of compassion is aligned with neoliberal logic, which facilitates capitalism in the disguise of a moral virtue.

These findings point that the humanitarian narratives in public affairs should not only be seen within the singular definition they are ascribed to in moral philosophy or popular understandings. Instead, they should be evaluated within the political context that produces and perpetuate them. When analyzed with the political context, these lofty ideals of humanitarianism do not always hold to the popular perception they carry. Instead, the humanitarian narratives become entangled with the 
broader logic of political economy and often tend to be subservient to the dominant discourse.

\section{LIMITATIONS}

One of the limitations of this research is the small number of interviews conducted. It should be noted that such a limited number of interviews were not initially planned. However, the emergence of the COVID-19 pandemic effectively restricted the data collection through interviews. The pandemic resulted in the social lockdown of Louisville, which restricted public meetings and the temporary shutdown of physical offices relevant to this research. Additionally, the government officials scheduled for interviews canceled their appointments citing their new priority of managing the public health crisis. More importantly, the University of Louisville directed suspension of all "non-essential: community-based research activity from early March. These drawbacks resulted in a limited number of interviews for the dissertation.

However, I tried to compensate for the absence of interviews with a more extensive dataset of archived documents. This includes city government reports and planning documents such as Vision Louisville 2040, Louisville's Blueprint for Safe and Healthy Neighborhoods (Phase 1 and 2), Progress Reports (2011-2018), Mayor Fischer's 100-Day Plan, Louisville Metro's Strategic Plan, Annual Budget reports, and relevant ordinances. I have also surveyed the meeting minutes of Metro Council from 2010 to March of 2020 to identify debates where the narrative of compassion has been used. Additionally, I have analyzed texts from the website of the city government, departments, and relevant non-profit organizations. The dataset also included local news publications, including Louisville Courier-Journal, WFPL, LEO 
Weekly, WDRB, Spectrum News, Wave3, and Insider Louisville (from 2010 to March 2020). Along with that, the interviewees (interviews conducted before the COVID19) also shared documents related to Compassionate Louisville, which were included in the analysis. Such extensive use of archived documents will hopefully compensate for the data loss due to the COVID19 pandemic.

Another limitation of the dissertation is the multiple possible interpretations of data. This critique is inherent to the methodological approach of CDA. The interpretation of textual data in CDA largely depends on the ontological position, analytical lens, and ethical positionality of the researchers. In this context, I acknowledge that there could be multiple interpretations of the same dataset. My interpretation of the texts, therefore, is uniquely mine and runs the risks of being critiqued by a reviewer with a different ontological and analytical lens.

\section{FUTURE RESEARCH}

Topics such as the politics of city branding, urban humanitarian governance, and the trend of Compassionate City are relatively understudied. These topics are becoming increasingly relevant in the contemporary urban political climate in the US. Hence, the dissertation makes an appeal to Urban Studies scholar for future research on relevant themes - that can range from specifics of Compassionate Louisville to broader scholarships on city branding, disciplining of emotion, and humanitarian narrative in urban politics. The following provides an outline of researches I am interested in conducting in the near future:

- Comprehensive Fieldwork on Compassionate Louisville 
One of the obvious scopes for future research is to conduct more extensive fieldwork on Compassionate Louisville to strengthen the findings presented here. This dissertation relies heavily on archived data such as newspaper articles, press releases, government websites, and meeting minutes of Metro Council. Extensive fieldwork was not possible largely due to the public health crisis of the Coronavirus since February 2020. In the future, when this public health crisis subsides, I am interested in conducting comprehensive fieldwork to collect primary data on the use of the discourse of compassion in Louisville. I am particularly interested in interviewing city government officials, members of the Metro Council, non-profit organizations, and activists who frequently make political claims with the narrative of compassion. Analysis of these primary data will strengthen and supplement the findings of this dissertation.

\section{- Legitimation of suffering and compassion}

Nussbaum (1996) conceptualized that the legitimacy of suffering depends on the perception that: (i) the suffering is not trivial; the magnitude of distress causes significant pain or loss; (ii) the suffering is not self-inflicted. However, this dissertation shows that both acknowledgments of suffering and acts of compassion to alleviate the suffering can not be deterministically theorized. Instead, they are constructed and legitimized through the politics of the city. I am interested in investigating this political construction of the legitimacy of suffering and acts of compassion. Why is certain suffering acknowledged and deemed worthy of support while others are not? In other words, what makes certain suffering socio-politically legitimate? Similarly, what makes certain acts of support legitimate compassion? How are these legitimacies constructed? 
- Connecting Racial Capitalism and Politics of Compassion

Racial capitalism refers to the capital's features of extracting social and economic value through racialism. It postulates that capital's perpetual need for accumulation can only be sustained by reproducing severe inequality in society. This inequality is not limited to differentiated ownership of wealth but also in terms of how different ethnic/racial groups are socially valued. In other words, class differentiation of capitalism depends not only on ownership of capital but also on race/ethnic segregation. Capitalism produces and exploits this unequal racial and ethnic differentiation of the society for accumulation (Leong 2013; Melamed 2015; Robinson 1983).

Although this dissertation does not directly use the concept of racial capitalism as an analytical lens, the findings open up a potential investigation on Compassionate Louisville using this perspective. The dissertation shows that Compassionate Louisville, as a neoliberal governance tool, extends differentiated compassion, services, and even rights. Sufferings of certain groups are readily acknowledged and alleviated; while distress of other groups is ignored and perpetuated. The historical racial social and spatial segregation of Louisville also accentuate this issue. The lens of racial capitalism can help to investigate how such differentiated extension of acknowledgment of suffering and vis-à-vis compassion reproduces racialized social class for the accumulation of capital. It can ask questions such as: how does the discourse of compassion produce differentiated groups: one who needs help and the other philanthropic? How do the latent racial values manifest in differentiated acknowledgment of suffering and extension of compassion in Louisville?

FINAL WORDS 
As the final words of this dissertation, I want to outline my utopian vision of Louisville, where I do not want it to be a "Compassionate City". Instead, I dream of Louisville to be a "Just City"- a city where the East and the West have equal life opportunities; where everybody has access to health; and where life-expectancy does not dramatically drop because of being born on the wrong neighborhood. I dream of a Louisville that is not racially segregated, where likes of Breonna Taylor do not get murdered, where certain communities are not exclusively incarcerated, and where an inability to afford property ownership is not criminalized. I envision an equitable Louisville, where access to basic services is not dependent on how much an individual can pay; instead, they are extended out of the rights of being a citizen. In my perfect version, I want Louisville to deliver social justice, not compassion.

Instead of compassion, what may exist is a sense of empathy as an accelerator of delivering social justice. Justice is not a stagnant concept and goes through perpetual evolution. Until 1920, just 100 years ago, women did not have the right to vote in the US. Up till the 1960s, black Americans were segregated in neighborhoods, schools, and public spaces. Until 2015 same-sex marriage was deemed illegal across most US States. These examples show that our concept of justice is ever-evolving and has expanded over time. More importantly, this evolution of justice is necessary; the socio-political institutions continue to produce conditions of marginalization that can only be addressed with the expansion of the notion of what constitutes as suffering and injustice. In this regard, empathy may play the role of a catalyst in the progression of justice. An orientation of empathy can actively acknowledge various forms of social suffering, misery, discrimination, marginalization, and violence. When suffering is acknowledged as injustice individually and collectively, the call to alleviate the suffering will become part of the public discourse leading to change in 
policy and legislature to institute it as rights. However, in my utopian Louisville, the sense of empathy will not lead to a paternalistic approach; rather, it should be seen as an aid to become a more "Just City."

In this utopian "Just Louisville", the political virtue of compassion will not be necessary. People should not have access to equitable living standards, health services, economic opportunities, and acceptance on the basis of compassion of the privileged. Instead, people should have these based on the premise that they are all equal right-bearing citizens. 


\section{REFERENCE}

Ahmed, Sara. 2010. "Happy Objects." In The Affect Theory Reader, edited by Melissa Gregg and Gregory J. Seigworth, 1-29. Durham and London: Duke University Press.

Abrahamsson, Christian, and Richard Ek. 2014. "Rereading David Harvey's 'From managerialism to entrepreneurialism' 25 years later." Geografiska Annaler B 96 (4): $387-388$.

Amato, Joseph. 1994. "Politics Of Suffering ." International Social Science Review 69 (1/2): 23-30.

Amoussou, Franck, and Ayodele A Allagbe. 2018. "Principles, Theories and Approaches to Critical Discourse Analysis." International Journal on Studies in English Language and Literature 6 (1): 11-18.

Anderson, Ben. 2012. "Affect and biopower: towards a politics of life." Transactions 37 (1): 28-43.

Anderson, Garry L., and Jamie Grinberg. 1998. " Educational Administration as a Disciplinary Practice: Appropriating Foucault's View of Power, Discourse, and Method." Educational Administration Quarterly 34 (3): 329-353.

Anholt, Simon;. 2007. Competitive Identity: The Brand Management for Nations, Cities and Regions. New York: Palgrave Macmillan.

Anttiroiko, Ari-Veikko . 2015. "City Branding as a Response to Global Intercity Competition." Growth and Change 46 (2): 233-252.

Archdiocese of Louisville. 2014. Keynote at Pro-Life Leadership Conference. 28 July. Accessed August 29, 2019. Retrieved from: https://www.archlou.org/keynote-at-pro-life-leadership-conference/.

Arendt, Hannah. 1963. On Revolution. London: Faber.

Armstrong, Karen. 1993. A History of God. New York: Ballentine Books.

Ashworth, Gregory John, and Henk Voogd. 1995. Selling the City: Marketing Approaches in Public Sector Urban Planning. Chichester: Wiley. 
Ashworth, Gregory. 2001. "The Communication of the Brand Images of Cities." The Construction and Communication of the Brand Images of Cities. Valencia: Universidad Internacional Menendez Pelayo conference.

Ave, Gastone. 1994. "Urban Planning and Strategic Urban Marketing in Europe." In Urban Marketing in Europe, by Gastone Ave and Franco Corsico, 126-159. Turin: Turin Incontra.

Bailey, Phillip. 2008. "Budget blues ." LEO Weekly, 26 November: retrieved from: https://www.leoweekly.com/2008/11/budget-blues/.

Barasch, Marc Ian. 2009. The Compassionate Life: Walking the Path of Kindness. Boulder, CO: Healing Path Books.

Barber, Benjamin. 1984. Strong Democracy: Participatory Politics of New Age. University of California Press.

Bayley, Paul. 2004. "Introduction ." In Cross-Cultural Perspectives on Parliamentary Discourse, by Paul Bayley, 1-44. Amsterdam/Philadelphia: John Benjamins.

Bean, Lydia. 2014. "Compassionate Conservatives? Evangelicals, Economic Conservatism, and National Identity." The Society for the Scientific Study of Religion 53 (1): 164-186.

Beck, Ulrich. 1986. Risk Society: Towards a New Modernity. SAGE Publications Ltd. Bennett, Roger, and Sharmila Savani. 2003. "The rebranding of city places: An international comparative investigation." International Public Management Review 4 (2): 70-87.

Bennett, William J. 1993. The book of virtues: A treasury of great moral stories. New York:: Simon and Shuster.

Berger, Ken, and Robert M. Penna. 2013. "The Elitist Philanthropy of So-Called Effective Altruism." Stanford Social Innovation Review, 25 November: http://ssir.org/articles/entry/the_elitist_philanthropy_of_so_called_effective_al truism.

Berlant, Lauren. 2004. "Introduction: Compassion (and witholding)." In Compassion: The culture and politics of an emotion, edited by Lauren Berlant, 1-14. New York and London: Routledge.

Besley, Tina. 2005. "Foucault, truth telling and technologies of the self in schools." The Journal of Educational Enquiry 6 (1): 76-89.

Blichfeldt, Bodil Stilling. 2005. "Unmanageable place brands?" Place Branding 1 (4): $388-401$. 
Boland, Philip. 2013. "Sexing up the City in the International Beauty Contest: The Performative Nature of Spatial Planning and the Fictive Spectacle of Place Branding." The Town Planning Review 84 (2): 251-274.

Bourdieu, Pierre. 1990. The Logic of Practice. Palo Alto, CA: Stanford University Press.

Boyd, Michael S., and Claudia Monacelli. 2010. "Politics, (con)text and genre: applying CDA and DHA to interpreter training." The Interpreters' Newsletter 15: 51-70.

Boyd, Richard. 2004. "Pity's Pathologies Portrayed: Rousseau and the Limits of Democratic Compassion." Political Theory 32: 519- 46.

Braun, Erik. 2011. "History matters: The path dependency of place brands." In International Place Branding Yearbook, by Frank M. Go and Robert Govers, 39-46. Basingstoken: Palgrave McMilla.

Brenner, Neil. 2009. "What is critical urban theory?" City, 13 (2-3): 198-207

Brownill, Susan. 1994. "Selling the inner city: regeneration and place marketing in London's Docklands." In Place Promotion: The Use of Publicity and Marketing to Sell Towns and Regions, by John R Gold and Stephen V Ward, 133-151. Chichester: Wiley.

Buchino, Susan, Catherine Fosl, Lora Haynes, Kelly Kinahan, Linda Omer, and Diane Zero. 2019. Solving Street Homelessness in Louisville, KY: Improving the Climate of Care for Individuals Experiencing Homelessness. Louisville: University of Louisville.

Burack, Cynthia. 2009. "Compassion Campaigns and Antigay Politics: What Would Arendt Do?" Politics and Religion 2 (1): 31-53.

Cacioppo, John T, and William Patrick. 2008. Loneliness: Human Nature and the Need for Social Connection. New York: Norton.

Castillo-Villar, Fernando. 2018. "City branding and the theory of social representation." Bitacora Urbano Territorial 28 (1): 31-36.

Castro, Paula, and Susana Batel. 2008. "Social Representation, Change and Resistance: On the Difficulties of Generalizing New Norms." Culture \& Psychology 14 (4): 475-497.

Castro, Paula. 2012. "Legal Innovation for Social Change: Exploring Change and Resistance to Different Types of Sustainability." Political Psychology 33 (1): $105-121$. 
Cathedral of Assumption. n.d. Compassion. Accessed August 29, 2019. Retrieved from: https://www.cathedraloftheassumption.org/parish-life/compassion/.

Centers for Disease Control and Prevention. 2014. " 500 Cities Project: Local Data for Better Health ." Louisville.

Chan, Joseph. 2003. "Confucian attitudes toward ethical pluralism. ." In The many and the one: Religious and secular perspectives on ethical pluralism in the modern world, edited by Madsen, Richard and Tracy Strong, 129-153.

Princeton: Princeton University Press.

Charter of Compassion. n.d. Read, Affirm and Share the Charter. Accessed May 20, 2020. Retreived from https://charterforcompassion.org/charter/affirm.

Chilton, Paul, and Chirstina Schäffner. 2002. "Introduction: Themes and principles in the analysis of political discourse." In Politics as Text and Talk: Analytic Approaches to Political Discourse, by Paul Chilton and Chirstina Schäffner, 1- 41. Amsterdam, Philadelphia: John Benjamins.

Chouliaraki, Lilie, and Norman Fairclough. 1999. Discourse in Late Modernity: Rethinking Critical Discourse Analysis. Edinburgh, UK: Edinburgh University Press.

Clark, Candace. 1987. "Sympathy Biography and Sympathy Margin." American Journal of Sociology 32 (2): 290-321.

Clark, Candace. 1997. Misery and Company: Sympathy in Everyday Life. Chicago \& London: The University of Chicago Press.

Cleave, Evan, and Godwin Arku. 2015. "Place branding and economic development at the local development in Ontario, Canada." GeoJournal 80: 323-338.

Clough, Patricia Ticineto. 2007. "The Affective Turn: Theorizing the Social." In Introduction, edited by Patricia Ticineto Clough and Jean Halley. Durham and London: Duke University Press.

Clough, Patricia Ticineto. 2008. "The Affective Turn: Political Economy, Biomedia and Bodies. ." Theory, Culture \& Society, 25 (1): 1-22.

Coalition for the Homeless Louisville . 2018. Metro Continuum of Care 2018 Homeless Census. Louisville: Coalition for the Homeless Louisville .

Cole, Nicki Lisa. 2019. "Introduction to Discourse in Sociology." ThoughtCo, 6 September. 
Collins, Mary Elizabeth, Kate Cooney, and Sarah Garlington. 2012. "Compassion in Contemporary Social Policy: Applications of Virtue Theory." Journal of Social Policy 41 (2): 251-269.

Collins, Mary Elizabeth, Sarah Garlington, and Kate Cooney. 2015. "Relieving Human Suffering: Compassion in Social Policy." The Journal of Sociology \& Social Welfare 42 (1): 95-120.

Colomb, Clarie, and Ares Kalandides. 2010. "The ‘be Berlin' campaign: old wine in new bottles." In Towards Effective Place Brand Management: Branding European Cities and Regions, by Mihalis Kavaratzis, 173-190. Cheltenham: Edward Elgar.

Comaroff, Jean, and John Comaroff. 2000. "Millenial capitalism: first thoughts on a second coming." Public Culture 12 (2): 291-343.

Compassionate Louisville. n.d. Partners Who Have Adopted Compassionate Organization Resolutions. Accessed December 23, 2019. Retrieved from: http://compassionatelouisville.weebly.com/partners.html.

Compassionate School Project. 2016. Program. Accessed June 11, 2020. Retrieved from: https://www.compassionschools.org/program/.

Comte-Sponville, André. 2001. A Small Treatise on the Great Virtues. New York: Holt \& Co.

Costello, Darcy. 2019. "Entrepreneurial Compassionate City Another reason why Louisville branded itself as Compassionate City could be the linked to the generic reason why a city tends to brand itself- to attract external capital. City branding is a strategic policy instrument." Courier Journal, 8 August: Retrieved from: https://www.courier-journal.com/story/news/politics/metrogovernment/2019/08/08/louisville-metro-council-passes-ordinanceintersection-panhandling/1955017001/.

Costello, Darcy. 2019. "Metro Council passes a safety ordinance that restricts panhandling, but with a few tweaks." Courier Journal, 8 August: Retrieved from: https://www.courier-journal.com/story/news/politics/metrogovernment/2019/08/08/louisville-metro-council-passes-ordinanceintersection-panhandling/1955017001/.

Cozolino, Louis. 2007. The Neuroscience of Human Relationships: Attachment and the Developing Brain. New York: Norton. 
Culham, Tom. 2014. "Cultivating Compassion 慈: A Daoist Perspective." Paideusis, $21(2): 32-41$.

D'Aoust, Anne-Marie. 2013. "In the Name of Love: Marriage Migration, Governmentality and Technologies of Love." International Political Sociology 7 (3): $258-274$.

D'Aoust, Anne-Marie. 2014. "Ties that Bind? Engaging Emotions, Governmentality and Neoliberalism: Introduction to the Special Issue." Global Society 28 (3): 267-276.

Darwin, Charles. 1878. The Descent of Man, and Selection in Relation to Sex. 2nd. Edited by James Moore and Adrian Desmond. New York: D. Appleton and Company.

Dawes, Simon, and Marc Lenormand. 2019. "Introduction." In Neoliberalism in Context Governance, Subjectivity and Knowledge, edited by Simon Dawes and Marc Lenormand. Springer International Publishing.

Dawney, Leila. 2013. "The Interruption: Investigating Subjectivation and Affect." Environment and Planning D: Society and Space 31 (4): 628-644.

Dean, Jon. 2015. "Volunteering, the Market, and Neoliberalism." People, Place and Policy 9 (2): 139-148.

Dean, Jon. 2015. "Volunteering, the market, and neoliberalism." People, Place and Policy 9 (2): 139-148.

Deane-Drummond, Celia. 2017. "Empathy and the evolution of compassion: From deep history to infused virtue." Zygon: Journal of Religion and Science 52 (1): $258-278$.

Deane-Drummond, Celia. 2017. "Is Empathy Immoral? Empathy and Evolution of Compassion: From Deep History to Infused Virtue." Zygon 52 (1): 258-278.

Deleuze, Gilles. 2004. Foucault. Paris: Les Editions de Minuit.

Dematteis, Giuseppe. 1994. "Urban Identity, City Image and Urban Marketing." In Managing and Marketing of Urban Development and Urban Life, by Gerhard Braun. Berlin: Dietrich Reimer Verlag.

Dinardi, Cecilia. 2017. "Cities for sale: Contesting city branding and cultural policies in Buenos Aires." Urban Studies 54 (1): 85-101.

Economic Innovation Group. 2016. "The 2016 Distressed Communities Index: An Analysis of Community Well-Being Across the United States." 
Eikenberry, Angela M., and Roseanne Marie Mirabell. 2018. "Extreme Philanthropy: Philanthrocapitalism, Effective Altruism, and the Discourse of Neoliberalism." Politics Symposium: Political Science \& Politics 51 (1): 43-47.

Ekman, Paul. 2010. "Darwin's Compassionate View of Human Nature." The Journal of the American Medical Association 303 (6): 557-558 .

Elahi, Amina. 2018. "In India, Fischer's Message Of Compassion Could Have Economic Benefits." WFPL, 16 February: Retrieve from: https://wfpl.org/inindia-fischer-message-of-compassion-could-have-economic-benefits/.

Ellis, Edward Sylvester. 1884. The Life of Colonel David Crockett. Philadelphia: Porter \& Coates.

Eshuis, Jasper, and Arthur Edwards . 2013. "Branding the City: The Democratic Legitimacy of a New Mode of Governance." Urban Studies 50 (5): 10661082.

Eshuis, Jasper, and Arthur Edwards. n.d. "Branding the city: The democratic legitimacy of a new mode of governance." Urban Studies 50 (5): 1066-1082. Fairclough, Norman, and Ruth Wodak. 1997. Critical Discourse Analysis. Vol. 2, in Discourse Studies: A Multidisciplinary Introduction, edited by Teun van Dijk, 258-284. London: Sage Publications.

Fairclough, Norman. 1985. "Critical and Descriptive Goals in Discourse Analysis." Journal of Pragmatics 0: 739- 763.

Fairclough, Norman. 1989. Language and power. London: Longman.

Fairclough, Norman. 1995. Critical Discourse Analysis. London: Longman. Fairclough, Norman. 2001. "Critical Discourse Analysis as a Method in Social Scientific Research." In Methods of Critical Discourse Analysi, by Ruth Wodak and Michael Meyer, 121-138. London: Sage.

Fairclough, Norman. 2003. Analysing Discourse: Textual Analysis for Social Research. London and New York: Routledge.

Fairclough, Norman.. 1992. Discourse and Social Change. Cambridge, UK: Polity Press.

Farr, James. 1989. "Understanding Conceptual Change Politically." In Political Innovation and Conceptual Change, by Terence Ball, James Farr and Russell Hanson, 24-49. Cambridge: Cambridge University Press. 
Farrelly, Michael. 2010. "Research and Analysis Critical Discourse Analysis in Political Studies: An Illustrative Analysis of the 'Empowerment' Agenda." Politics 30 (2): 98-104.

Fassin, Didier. 2012. Humanitarian Reason: A Moral History of the Present. Berkeley: University of California Press.

Feldwick, Paul. 1996. "What is Brand Equity Anyway, and how do you Measure it?" International Journal of Market Research 38 (2): 1-17.

Ferguson, James. 2010. "The uses of Neoliberalism." Antipode 41 (S1): 166-184.

Fierke, Karin M. 2013. Political Self-Sacrifice: Agency, Body and Emotion in International Relations . Cambridge: Cambridge University Press.

Florida, Richard. 2002. The Rise of the Creative Class. New York: Basic Boks.

Foucault, Michel. 1977. Discipline and punish : the birth of the prison. New York: Pantheon Books.

Foucault, Michel. 1978. The History of Sexuality, Vol 1. Translated by Robert Hurley. Éditions Gallimard.

Foucault, Michel. 2003. "Society Must Be Defended": Lectures at the Collège de France, 1975-76. Edited by Mauro Bertani and Alessandro Fontana. New York: Picador.

Foucault, Michel. 2004. The Birth of Biopolitics: Lectures at the Collège de France, 1978-1979. New York: Palgrave Macmillan.

Foucault, Michel. 2007. Security, Territory, Population: Lectures at the College De France, 1977 - 78. Translated by Graham Burchell. Palgrave Macmillan.

Fowler, Roger. 1991. Language in the news: Discourse and ideology in the press. London; New York, NY: Routledge.

Freire, Joao. 2005. "Geo-branding, are we talking nonsense? A theoretical reflection on brands applied to places." Place Branding 1 (4): 347-362.

Friedmann, John. 1987. Planning in the Public Domain: From Knowledge to Action. Princeton, NJ: Princeton University Press.

Gabriel, Nathaniel. 2020. "Paradox and possibility: voluntarism and the urban environment in a post-political era." Social \& Cultural Geography 21 (2): $143-161$.

Gardner, Drew. 2019. "Louisville neighborhood frustrated by growing homeless camp." WLKY, 11 November: Retrieved from: 
https://www.wlky.com/article/louisville-neighborhood-frustrated-by-growinghomeless-camp/29765856.

Geuss, Raymond. 1981. The Idea of a Critical Theory Habermas and the Frankfurt School. New York: Cambridge University Press

Gil, Marta. 2016. "Emotions and political rhetoric: Perception of danger, group conflict and the biopolitics of fear." Human Affairs 26 (2): 212-226.

Gilbert, Paul. 2015. "The Evolution and Social Dynamics of Compassion." Social and Personality Psychology Compass 9 (6): 239-254.

Gilligan, Carol. 1982. In a Different Voice. Cambridge, MA: Harvard University Press.

Giovanardi, Massimo, Andrea Lucarelli, and Cecilia Pasquinelli. 2013. "Towards brand ecology: An analytical semiotic framework for interpreting the emergence of place brands." Marketing Theory 13 (3): 365-383.

Gleeson, Brendan, and Robin Kearns. 2001. "Remoralising landscapes of care." Environment and Planning D:Society and Space 19: 61 - 80.

Go To Louisville. n.d. International Welcome. Accessed May 20, 2020. https://www.gotolouisville.com/travel-tools/international-welcome/.

Godfrey, Elaine. 2018. "What 'Abolish ICE' Actually Means." The Atlantic, 11 July: Retrieved from: https://www.theatlantic.com/politics/archive/2018/07/whatabolish-ice-actually-means/564752/.

Gramsci, Antonio. 1971. Selections from Political Writings, 1910- 1920 : With Additional Texts by Bordiga and Tasca. New York: International Publishers.

Greater Louisville Convention and Visitors Bureau. 2017. Resetting The Way We Market Louisville. Louisville: Go To Louisville.

Greater Louisville Convention and Visitors Bureau. 2018. Louisville Brand Book. Louisville: Go To Louisville.

Greater Louisville Project. 2015. "Louisville - A Focus on Poverty." Louisville. Greater Louisville Project. 2017. "Poverty Beyond Income." Louisville.

Greater Louisville Project. n.d. Income Inequality. Accessed May 28, 2020. Retrieved from: https://greaterlouisvilleproject.org/factors/income-inequality/.

Green, Amelia, Grace Debra, and Helen Perkins. 2016. "City branding research and practice: An integrative review." The Journal of Brand Management 23 (3): 252-272. 
Greenberg, Miriam. 2008. Branding New York: How a City in Crisis was Sold to the World. New York: Routledge.

Greenop, Kelly, and Se'bastien Darchen. 2016. "Identifying 'place' in place branding: core and periphery in Brisbane's "New World City"." GeoJournal 81: 379394.

Gregory, James. 2015. "Engineering Compassion: The Institutional Structure of Virtue ." Journal of Soical Policy 44 (2): 339-356.

Griffiths, Mark, and Eleanor J. Brown. 2017. "Embodied experiences in international volunteering: power-body relations and performative ontologies." Social \& Cultural Geography 18 (5): 665-682.

Habermas, Jürgen. 1985. The Theory of Communicative Action. Translated by Thomas McCarthy. Vol. 1. Boston: Beacon.

Hackworth, Jason. 2012. "Compassionate Neoliberalism?" In Faith Based: Religious Neoliberalism and the Politics of Welfare in the United States, edited by Deborah Cowen, Nik Heynen and Melissa Wright, 48-62. Athens, Georgia: University of Georgia Press.

Hall, Stuart. 2011. "The Neo-Liberal Revolution." Cultural Studies 25 (6): 705-728. Halttunen, Karen. 1995. "Humanitarianism and the Pornography of Pain in AngloAmerican Culture." The American Historical Review 100 (2): 303-334.

Hansen, Rebecca Hjortegaard. 2010. "The narrative nature of place branding." Place Branding and Public Diplomacy 6 (4): 268-279.

Hardt, Michael. 1999. "Affective Labor." boundary 226 (2): 89-100.

Hart, Herbert. 1982. Essays on Bentham: studies in jurisprudence and political theory. Oxford: Clarendon Press.

Harvey, David. 1989. "From managerialism to entrepreneurialism: The transformation in urban governance in late capitalism." Human Geography 71 (1): $3-17$.

Harvey, David. 2007. A Brief History of Neoliberalism. Oxford : Oxford University Press.

Haskell, Thomas L. 1985. "Capitalism and the Origins of the Humanitarian Sensibility, Part 1." The American Historical Review 90 (2): 339-361.

Hassan, Riffat. 2017. "Is 'compassion' the safe word for Muslims?" Courier Journal, 28 June: Retrieved from: https://www.courier- 
journal.com/story/opinion/contributors/2017/06/28/compassion-go-safe-wordmuslims-riffat-hassan/429296001/.

Hayak, Friedrich. 1944. The Road to Serfdom. University of Chicago Press.

Henriksen, Lars S., Stephen R. Smith, and Annette Zimmer. 2012. "At the Eve of Convergence? Transformations of Social Service Provision in Denmark, Germany, and the United States." Voluntas 23 (2): 458-501.

Hernandez-Garcia, J, and Celia Lopez. 2011. "Is There a Role for Informal Settlements in Branding Cities?" Journal of Place Management and Development 4 (1): 93-109.

Hirschman, Nancy. 2000. "Sympathy, Empathy and Obligation ." In Feminist Interpretations of David Hume, edited by Anne Jaap Jacobson, 17. University Park: Pennsylvania State University Press.

Hubbard, Phil, and Tim Hall. 1996. "The entrepreneurial city and the new urban politics." Progress in Human Geography 20 (2): 153-174.

Insch, Andrea. 2011. "Ethics of place making." Place Branding and Public Diplomacy 7 (3): 151-154.

Institute on Taxation and Economic Policy. 2018. "Who Pays? A Distributional Analysis of the Tax Systems in All 50 States." Washington, DC.

Jäger, Siegfried. 2001. "Discourse and knowledge: theoretical and methodological aspects of a critical discourse and dispositive analysis." In Methods of Critical Discourse Analysis, by Ruth Wodak and Michael Meyer, 32-62. London: Sage.

Jazaieri, Hooria, Geshe Thupten Jinpa, Kelly McGonigal, Erika L. Rosenberg, Joel Finkelstein, Emiliana Simon-Thomas, Margaret Cullen, James R. Doty, James J. Gross, and Philippe R. Goldin. 2013. "Enhancing Compassion: A Randomized Controlled Trial of a Compassion Cultivation Training Program." Journal of Happiness Studies 13: 1113-1126.

Jefforson County Public Schools. 2016. Compassionate Schools Project Announces Four Major Grants Totaling \$4.4M \& Launch of Full Implementation. 5

October. Accessed June 11, 2020. Retrieved from:

https://www.jefferson.kyschools.us/departments/communications/mondaymemo/compassionate-schools-project-announces-four-major-grants. 
Jewish Community Center of Louisville. 2018. Compassion for immigrants is the Jewish way. 24 January. Accessed December 23, 2019. https://jewishlouisville.org/compassion-immigrants-jewish-way/.

Johansson, Marjana. 2012. "Place Branding and the Imaginary: The Politics of Reimagining a Garden City." Urban Studies 49 (16): 3611-3626.

Jokela, Salla. 2020. "Transformative city branding and the evolution of the entrepreneurial city: The case of 'Brand New Helsinki'." Urban Studies 57 (10): 2031-2046.

Joo, Yu-Min, and Bokyong Seo. 2018. "Transformative city branding for policy change: The case of Seoul's participatory branding." Environment and Planning C: Politics and Space 36 (2): 239-257.

Joseph, John Earl. 2006. Language and Politics. Edinburgh: Edinburgh University Press.

Kaika, Maria. 2017. "Between compassion and racism: how the biopolitics of neoliberal welfare turns citizens into affective "idiots'." European Planning Studies 25 (8): 1275-1291 .

Kanov, Jason M., Sally Maitlis, Monica C. Worline, Jane E. Dutton, Peter J. Frost, and Jacoba M. Lilius. 2004. "Compassion in Organizational Life." American Behavioral Scientist 47 (6): 808-827.

Kapferer, Jean-Noël. 2011. "Paris as a brand." In City Branding: Theory and Cases, by Keith Dinnie, 184-189. Basingstoke, UK: Palgrave Macmillan.

Kavaratzis, Mihalis, and Gregory Ashworth. 2005. "City Branding: An Effective Assertion of Identity or a Transitory Marketing Trick?" Tijdschrift voor Economische en Sociale Geografie 96 (5): 506-514.

Kavaratzis, Mihalis, and Gregory Ashworth. 2009. "Beyond the Logo: Brand Management for Cities." Journal of Brand Management 16 (8): 520-531.

Kavaratzis, Mihalis. 2015. "Place branding scholars and practitioners: "Strangers in the night"?" Journal of Place Management and Development 8 (3): 266-270.

Keltner, Dacher, Aleksandr Kogan, Paul K. Piff, and Sarina R. Saturn. 2014. "The Sociocultural Appraisals, Values, and Emotions (SAVE) Framework of Prosociality: Core Processes from Gene to Meme." Annual Review of Psychology 65: 425-460.

Kentucky Tourism, Arts and Heritage Cabinet. 2017. "Economic Impact Of Kentucky's Travel And Tourism Industry - 2015 And 2016." 
Khirfan, Luna, and Bessma Momani. 2013. "(Re)branding Amman: A 'lived' city's values, image and identity." Place Branding and Public Diplomacy, 9 (1): 49 65.

Kiersey, Nicholos J. 2014. "“Retail Therapy in the Dragon's Den”: Neoliberalism and Affective Labour in the Popular Culture of Ireland's Financial Crisis." Global Society 28 (3): 356-374.

Kipfer, Stefan, and Roger Keil. 2002. "Toronto Inc. Planning the competitive city in the new Toronto." Antipode 34 (2): 227-264.

Kirvalidze, Nino, and Nino Samnidze. 2016. "Political Discourse as a Subject of Interdisciplinary Studies." Journal of Teaching and Education 5 (1): 161-170.

Klayko, Branden. 2016. "Interview: Mayor Greg Fischer on what Louisville does right." Broken Sidewalk, 10 February: Retrieved from: https://brokensidewalk.com/2016/greg-fischer-interview/.

Klein, Richard D. 1999. The Human Career, Human Biological and Cultural Origins. Chicago: University of Chicago Press. .

Klimecki, Olga M., Sussane Leiberg, Mathieu Ricard, and Tania Singer. 2014. "Differential pattern of functional brain plasticity after compassion and empathy training." Social Cognitive \& Affective Neuroscience 9: 873-879.

Kogan, Aleksandr, Christopher Oveis, Evan W. Carr, June Gruber, Iris B. Mauss, Amanda Shallcross, Emily A. Impett, et al. 2014. "Vagal activity is quadratically related to prosocial traits, prosocial emotions, and observer perceptions of prosociality." Journal of Personality and Social Psychology 107: 1051-1063.

Larner, Wendy. 2006. "Neoliberalism: Policy, Ideology, Governmentality." In International Political Economy and Poststructural Politics, edited by Marieke de Goede, 199-218. London: Palgrave Macmillan.

Larson, Chris. 2020. "Louisville Urban League president calls for firing of officers in Taylor case." Louisville Buisness First, 29 May: Retrieved from: https://www.bizjournals.com/louisville/news/2020/05/29/sadiqa-reynoldsfiring-lmpd-breonna-taylor.html.

Lefebvre, Henry. 1968. The Right to the City. Paris.

Leonard, Connie. 2018. "Protesters demand accountability after officer-involved shootings." Wave3 News, 26 April: Retrieved from: 
https://www.wave3.com/story/38052127/protesters-demand-accountabilityafter-officer-involved-shootings/.

Leong, Nancy. 2013. "Racial Capitalism." Harvard Law Review 126 (8): 2151-2226. Levinson-Waldman, Rachel, and Haley Hinkle. 2018. "The Abolish ICE Movement Explained." Brennan Center for Justice, 30 July:

https://www.brennancenter.org/our-work/analysis-opinion/abolish-icemovement-explained.

Li, Tania Murray. 2007. "Governmentality." Anthropologica 49 (2): 275-281.

Lobb, Andrea. 2015. "Technologies of the Other: Renewing 'empathy' between Foucault and psychoanalysis." Foucault Studies 20: 218-235.

Locke, Terry. 2004. Critical Discourse Analysis. London: Cromwell Press. Louisville Bar Association. 2015. Compassionate Lawyers? You Bet! Accessed November 20, 2019. Retrived from: https://www.loubar.org/news/article/?id=116.

Louisville Future. 2016. "A conversation with Mayor Fischer about compassion." 24 Novermber: Retrieved from: https://louisvillefuture.com/archivednews/compassionate-city/.

Louisville Future. 2017. "Fischer suspends clearing of homeless camps until notification ordinance is passed." 18 December: Retrieved from: https://louisvillefuture.com/archived-news/fischer-suspends-clearing-ofhomeless-camps-until-notification-ordinance-is-passed/.

Louisville Metro Affordable Housing Trust Fund. 2019. Louisville Housing Need Assessment. Louisville: Louisville-Jefferson County Metro Government. Louisville-Jefferson County Metro Government. 2015. Mayor Rallies Community for "Give A Day" Week of Service. 10 March. Accessed May 20, 2020. Retrieved from: https://louisvilleky.gov/news/mayor-rallies-community-give-day-weekservice-april-18-26.

Louisville-Jefferson County Metro Government. 2016. Compassionate Schools Project announces program fully under way; grants totaling $\$ 4.4 M .6$ October. Accessed June 11, 2020. Retrieved from: https://louisvilleky.gov/news/compassionate-schools-project-announcesprogram-fully-under-way-grants-totaling- $44 \mathrm{~m}$.

Louisville-Jefferson County Metro Government. 2016. Give A Day Week Impacts Louisville With 175,000 Volunteers, Acts of Compassion. 27 April. Accessed 
May 20, 2020. Retrieved from: https://louisvilleky.gov/news/give-day-weekimpacts-louisville-175000-volunteers-acts-compassion.

Louisville-Jefferson County Metro Government. 2017. Mayor Fischer's remarks for the 2017-18 proposed budget. 27 April. Accessed May 20, 2020. Retrieved from: https://louisvilleky.gov/news/mayor-fischers-remarks-2017-18proposed-budget.

Louisville-Jefferson County Metro Government. 2019. "Fiscal Year 2019-2020: Louisville Metro Approved Executive Budget." Louisville.

Louisville-Jefferson County Metro Government. 2019. Mayor Fischer declares June 10-17 Pride Week in Louisville. Accessed May 20, 2020. Retrieved from: https://louisvilleky.gov/news/mayor-fischer-declares-june-10-17-pride-weeklouisville.

Louisville-Jefferson County Metro Government. 2019. Mayor rallies community for eighth annual Give A Day Week of Service. Accessed April 30, 2020. Retrieved from: https://louisvilleky.gov/news/mayor-rallies-communityeighth-annual-give-day-week-service-april-13-20.

Louisville-Jefferson County Metro Government. 2019. Mayor rallies community for eighth annual Give A Day Week of Service, April 13-20. Accessed April 30, 2020. Retreived from: https://louisvilleky.gov/news/mayor-rallies-communityeighth-annual-give-day-week-service-april-13-20.

Louisville-Jefferson County Metro Government. 2019. Mayor rallies community for eighth annual Give A Day Week of Service, April 13-20. Accessed April 30, 2020. Retrieved from: https://louisvilleky.gov/news/mayor-rallies-communityeighth-annual-give-day-week-service-april-13-20.

Louisville-Jefferson County Metro Government. 2019. Plan 2040: Comprehensive Plan for Louisville/Jefferson County. Louisville, Kentucky.

Louisville-Jefferson County Metro Government. 2020. The Louisville Metro Council releases statement concerning last night protests and violence surrounding the death of Breonna Taylor. 29 May. Accessed June 20, 2020. Retrieved from: https://louisvilleky.gov/news/louisville-metro-council-releases-statementconcerning-last-night-protests-and-violence.

Louisville-Jefferson County Metro Government. n.d. Compassionate Cities Mission Statement. Accessed May 20, 2020. Retreived from: 
https://louisvilleky.gov/government/compassionate-city/compassionate-citiesmission-statement.

Louisville-Jefferson County Metro Government. n.d. Emergency Services - Our Mission. Accessed May 20, 2020. Retrieved from:

https://louisvilleky.gov/government/emergency-services/about-us.

Louisville-Jefferson County Metro Government. n.d. Goal 21: Grow as a

Compassionate City. Accessed May 20, 2020. Retrieved from:

https://louisvilleky.gov/government/mayor-greg-fischer/strategic-plan2017/goal-21-grow-compassionate-city.

Louisville-Jefferson County Metro Government. n.d. Helping our Homeless

Neighbors. Accessed May 20, 2020. Retrieved from:

https://louisvilleky.gov/government/resilience-and-community-

services/helping-our-homeless-neighbors.

Louisville-Jefferson County Metro Government. n.d. Louisville is a Compassionate City. Accessed May 20, 2020. Retrieved from:

https://louisvilleky.gov/government/compassionate-city.

Louisville-Jefferson County Metro Government. n.d. Resilience and Community Services Overview. Accessed May 20, 2020. Retrieved from:

https://louisvilleky.gov/government/resilience-and-community-services/aboutus.

Lucarelli, Andrea, and Per Olof Berg. 2011. "City Branding: A State-of-the-art Review of the Research Domain." Journal of Place Management and Development 4 (1): 9-27.

Lucarelli, Andrea. 2018. "Place branding as urban policy: The (im)political place branding." Cities 80: 12-21.

Lyles, Ward, Stacey Swearingen White, and D Brooke. 2018. "The Prospect of Compassionate Planning." Journal of Planning Literature 33 (3): 247-266.

Lyon, Alynna J., and Chris J. Dolan. 2007. "American Humanitarian Intervention: Toward a Theory of Coevolution." Foreign Policy Analysis 3 (1): 46-78.

Macpherson, Crawford. 1977. The Life and Times of Liberal Democracy. Oxford, New York: Oxford University Press.

Marketplace. 2017. "Can compassion have economic benefits?" Marketplace, 29 August: Retrieved from: https://www.marketplace.org/2017/08/29/cancompassion-have-economic-benefits/. 
Marks, Jonathan. 2007. "Rousseau's discriminating defense of compassion." American Political Science Review 10 (4): 727-739.

Mavelli, Luca. 2017. "Governing populations through the humanitarian government of refugees: Biopolitical care and racism in the European refugee crisis." Review of International Studies 43 (5): 809-832.

McCarthy, Kathleen. 1990 . Lady bountiful revisited: Women, philanthropy, and power. Brunswick, NJ: Rutgers University Press.

McKenna, Bernard. 2004. "Critical Discourse Studies: Where To From Here?" Critical Discourse Studies 1 (1): 9 -39.

Meador, Jonathan. 2018. "Encampment aims to 'Abolish ICE,' pressure mayor." Insider Louisville, 2 July: Retrieved from:

https://louisvillefuture.com/archived-news/encampment-aims-to-abolish-icepressure-mayor/?i.

Medway, Dominic, and Gary Warnaby. 2014. "What's in a name? Place branding and toponymic commodification." Environment and Planning A 46: 153-167.

Melamed, Jodi. 2015. "Racial Capitalism." Critical Ethnic Studies 1 (1): 76-85.

Metro United Way. 2019. Mayor's Give A Day Week of Service. Accessed May 20, 2020. Retrieved from: https://metrounitedway.org/give-a-day-mayors-weekof-service/.

Meyer, Michael. 2001. "Between theory, method, and politics: Positioning of the approaches to CDA." In Methods of critical discourse analysis, by Ruth Wodak and Michael Meyer. London: Sage.

Mill, John Stuart. 1859. On Liberty. London: John W. Parker and Son.

Mills, Chad. 2019. "Metro Council OKs sweeping cuts and layoffs, passing bleak budget by a huge margin." WDRB, 29 June: Retrieved from: https://www.wdrb.com/news/metro-council-oks-sweeping-cuts-and-layoffspassing-bleak-budget/article_c031fdb2-9785-11e9-817c.

Mitchell, Katharyne, and Key MacFarlane. 2019. " Beyond the Educational Dystopia: New Ways of Learning through Remembering." Socialist Register 56: 84-103. Mogashoa, Tebogo. 2014. "Understanding Critical Discourse Analysis in Qualitative Research." International Journal of Humanities Social Sciences and Education 1 (7): 104-113.

Morris, David B. 1991. The Culture of Pain. Los Angeles, London: University of Berkeley. 
Murphy, Stacey. 2009. "“Compassionate” Strategies of Managing Homelessness: Post-Revanchist Geographies in San Francisco." Antipode 41 (2): 305-325. Muslim Americans for Compassion. n.d. MACUS. Accessed December 23, 2019. Retrieved from: https://macus.org/who-we-are/.

Myerhoff, Barbara, and Jay Ruby. 1982. A Crack in the Mirror: Reflexive Perspectives in Anthropology. Edited by Jay Ruby. Philadelphia: University of Pennsylvania Press.

Nadesan, Majia Holmer. 2008. Governmentality, Biopower, and Everyday Life. . New York: Routledge.

Naples, Nancy. 1992. "ACTIVIST MOTHERING: Cross-Generational Continuity in the Community Work of Women from Low-Income Urban Neighborhoods." Gender \& Society 6 (3): 441-463.

National Immigration Legal Services Directory. n.d. Compassionate Legal Services of Louisville and Southern Indiana, Inc. Accessed November 20, 2019. Retrieved from:

https://www.immigrationadvocates.org/nonprofit/legaldirectory/organization.5 $81377-$

Compassionate_Legal_Services_of_Louisville_and_Southern_Indiana_Inc_L ouisvi.

National LGBT Chamer of Commerce. 2020. Louisville, KY Passes Ordinance to include Certified LGBT-owned Businesses in City Contracts and Programs. Accessed June 11, 2020. Retrieved from: https://www.nglcc.org/pressrelease/louisville-ky-passes-ordinance-include-certified-lgbt-ownedbusinesses-city-contracts.

Nelissen, Rob M. A., Seger M. Breugelmans, and Marcel Zeelenberg. 2013.

"Reappraising the Moral Nature of Emotions in Decision Making: The Case of Shame and Guilt." Social and Personal Psychology Compass 7 (6): 355-365.

Neuhaus, Richard John. 1977. The World Council of Churches and Radical Chic. Georgetown University Press.

Newport, Frank, and Gary Gates. 2015. "San Francisco Metro Area Ranks Highest in LGBT Percentage." Gallup- Social Policy Issues, 20 March: Retrieved from: https://news.gallup.com/poll/182051/san-francisco-metro-area-ranks-highestlgbt- 
percentage.aspx?utm_source $=$ Social\%20Issues\&utm_medium $=$ newsfeed\&ut m_campaign $=$ tiles.

Nickel, Patricia M., and Angela M. Eikenberry. 2010. "Philanthropy in an Era of Global Governance." In Third Sector Research, edited by Rupert Taylor, 26979. New York: Springer.

Novak, Michael. 1980. Toward a Theology of the Corporation. Washington, DC: American Enterprise Institute.

Nussbaum, Martha. 1996. "Compassion: The basic social emotion." Social Philosophy and Policy 13: 27-58.

Nussbaum, Martha. 2001. Upheavals of Thought: The Intelligence of Emotions. New York: Cambridge University Press.

Oguztimur, Senay, and Ulun Akturan . 2015. "Synthesis of City Branding Literature (1988-2014) as a Research Domain." International Journal of Tourism Research 18 (4): 357-372.

Olasky, Marvin. 2000. Compassionate Conservatism: What it is, What it Does, and How it Can Transform America. New York: The Free Press.

Omies Yoga Studio. n.d. Welcome! Accessed May 20, 2020. Retrieved from: https://www.omiesyogastudio.com.

Ooi, Can-Seng. 2004. "The poetics and politics of destination branding:Denmark." Scandinavian Journal of Hospitality and Tourism 3 (2): 107-128.

Paganoni, Maria Cristina . 2012. "City Branding and Social Inclusion in the Glocal City." Mobilities 7 (1): 13-31.

Papadopoulos, Nicolas. 2004. "Place branding: Evolution, meaning and implications." Place Branding 1 (1): 36-49.

Parkerson, Brenda. 2007. "From schlock to hot: Shifting perceptions of Brooklyn." Place Branding and Public Diplomacy 3 (4): 263-267.

Pasquinelli, Cecilia. 2010. "The limits of place branding for local development: The case of tuscany and the Arnovalley Brand." Local Economy 25 (7): 558-572.

Pasquinelli, Cecilia. 2013. "Branding as urban collective strategy-making: The formation of Newcastle Gateshead's organizational identity." Urban Studies $51(4): 727-743$.

Peck, Jamie, and Adam Tickell. 2002. "Neoliberalizing Space." Antipode 34: 380404. 
Peck, Jamie. 2010. Constructions of Neoliberal Reason. Oxford: Oxford University Press.

Peck, Jamie. 2014. " Entrepreneurial urbanism: Between uncommon sense and dull compulsion." Geografiska Annaler B 96 (4): 396-401.

Peck, Jamie. 2017. "Neoliberalism." In International Encyclopedia of Geography:

People, the Earth, Environment and Technology, edited by Douglas

Richardson, Noel Castree, Michael Goodchild, Audrey Kobayashi, Weidong Liu and Richard Marston. Wiley Online Library.

Pedwell, Carolyn. 2014. Affective Relations The Transnational Politics of Empathy. London: Palgrave Macmillan.

Penner, Louis A., John F. Dovidio, Jane A. Piliavin, and David A. Schroeder. 2005. "Prosocial Behavior: Multilevel Perspectives ." Annual Review of Psychology 56: 365-392 .

Pilbeam, Bruce. 2003. "Natural allies? Mapping the relationship between conservatism and environmentalism." Political Studies 51 (3): 490- 508.

Platt, Plam. 2017. "Inside the Center of the Abortion Storm." Leo Weekly, 23 August:

Retrieved from: https:/www.leoweekly.com/2017/08/exclusive-inside-center/.

Poovey, Mary. 1995. Making a Social Body: British Cultural Formation, 1830-1864.

Chicago \& London: The University of Chicago Press.

Porter, Elisabeth. 2009. " Can politics practice compassion?" Hypatia 21 (4): 97-123.

Porter, Libby, Leonie Sandercock, Karen Umemoto, Lisa Bates, Marisa Zapata, Michelle Kondo, Andrew Zitcer, et al. 2012. "What's Love Got to Do with It? Illuminations on Loving Attachment in Planning." Planning Theory \& Practice 13 (4): 593-627.

Powers, Penny. 2007. "The Philosophical Foundations of Foucaultian Discourse Analysis." Critical Approaches to Discourse Analysis across Disciplines 1 (2): $18-34$.

Protevi, John. 2009. "What does Foucault think is new about neo-liberalism?" Warwick Journal of Philosophy 21: 9-14.

Pryor, Brandy N.K., Rebecca Hollenbach, Aja Barber, and MS. T. Gonzales. 2017. Health Equity Report: Uncovering the Root Causes of Health. Louisville: Louisville Metro Department of Public Health and Wellness. 
Rainbow Advocacy. 2013. Colors of Compassion 2013. Accessed August 29, 2019. Retrieved from: https://www.rainbowadvocacy.org/colors-of-compassion2013.html.

Ratterman, Lexie, and Gilbert Corsey. 2019. "Homeless forced to relocate as Louisville cleans out camps." WDRB, 16 July: Retrieved from: https://www.wdrb.com/news/homeless-forced-to-relocate-as-louisville-cleansout-camps/article_84580a24-a7c1-11e9-ad1c-578.

Rauch, Jonathan. 2019. "It's Time to Drop the 'LGBT' From 'LGBTQ'." The Atlantic, January: Retrieved from URL https://www.theatlantic.com/magazine/archive/2019/01/dont-call-me$\operatorname{lgbtq} / 576388 /$.

Reid, Julian. 2011. "The Biopoliticization of Humanitarianism: From Saving Bare Life to Securing the Biohuman in Post-Interventionary Societies." Journal of Intervention and Statebuilding 4 (4): 391-411.

Richardson, John. 2007. Analysing newspapers: An approach from critical discourse analysis. Basingstoke; New York: Palgrave Macmillan.

Robert, Higgs, and Elizabeth Bernard Higgs. 2015. "Compassion-a Critical Factor for Attaining and Maintaining a Free Society." The Independent Review 19 (4): 627-630.

Robinson, Cedric. 1983. Black Marxism. Chapel Hill \& London: The University of North Carolina Press.

Roots. n.d. Roots: Mindful, Compassionate Cooking. Accessed November 20, 2019. Retrieved from: http://www.heartandsoy.net.

Rossi, Ugo, and Alberto Vanolo. 2015. "Urban neoliberalism." In International Encyclopedia of the Social and Behavioral Sciences, edited by James Wright, 846-853. Amsterdam: Elsevier.

Rousseau, Max. 2009. "Re-imaging the city centre for the middle classes: Regeneration, Gentrification and symbolic policies in 'loser cities'." International Journal of Urban and Regional Research 33 (3): 770-788.

Ruez, Derek, and Trushna Parekh. 2019. "'There is no political agenda' - Governing and contesting the compassionate city in Louisville." City 23 (1): 17-34.

Rust, Kaitlin. 2019. "Louisville's homeless population has increased, but less are sleeping on the streets." Wave3 News, 29 April: Retrieved from: 
https://www.wave3.com/2019/04/20/louisvilles-homeless-population-hasincreased-less-are-sleeping-streets/.

Rutland, Ted. 2015. "Enjoyable life: Planning, amenity and the contested terrain of urban biopolitics." Environment and Planning D: Society and Space 33 (5): $850-868$.

Ryan, Jacob, and Alexandra Kanik. 2018. "Instability Grows As Louisville Eviction Rate Doubles National Average." Kentucky Center of Investigative Reporting, 5 July: Retrieved from: https://kycir.org/2018/07/05/eviction-in-louisville/.

Ryan, James. 1991. "Observing and Normalizing: Foucault, Discipline, and Inequality in Schooling: BIG BROTHER IS WATCHING YOU." The Journal of Educational Thought 25 (2): 104-119 .

Sayers, Justin, and Phillip Bailey. 2017. "Louisville helps homeless man as his camp is wiped out, but others aren't as lucky." Courier Journal, 8 December: Retrieved from: https://www.courier-journal.com/story/news/politics/metrogovernment/2017/12/08/homeless-camp-razed-downtown-louisvillecompassionate-city/934026001/.

Sayers, Justin, and Phillip M. Bailey. 2017. "Louisville helps homeless man as his camp is wiped out, but others aren't as lucky." Courier Journal, 8 December: Retrieved from: https://www.courier-journal.com/story/news/politics/metrogovernment/2017/12/08/homeless-camp-razed-downtown-louisvillecompassionate-city/934026001/.

Schecter, Darrow. 2010. The Critique of Instrumental Reason from Weber to Habermas. New York: Continuum.

Scheer, Monique. 2012. "Are Emotions a Kind of Practice (And Is That What Makes Them Have a History)? A Bourdieusian Approach to Understanding Emotion." History and Theory 51 (2): 193-220.

Schmitt, Christopher S, and Candace Clark. 2006. "Sympathy." In Handbook of the sociology of emotions, by Jonathan Turner and Jan Stets, edited by Jan Stets and Jonathan H. Turner, 467-492. New York: Springer.

Schuller, Kyla. 2018. The Biopolitics of Feeling: Race, Sex, and Science in the Nineteenth Century. Durham: Duke University Press.

Schwak, Juliette. 2016. "Branding South Korea in a Competitive World Order: Discourses and Dispositives in Neoliberal Governmentality." Asian Studies Review 40 (3): 427-444. 
Scott, Allen, and Michael Storper. 2015. "The Nature of Cities: The Scope and Limits of Urban Theory." International Journal of Urban and Regional Research 39 (1): $1-15$.

Scott, Roxanne. 2016. "Black Lives Matter-Louisville Leader On What Comes Next." WFPL, 12 July: Retrieved from https://wfpl.org/what-activist-chanelle-helmwould-like-to-see-change/.

Sears, David. 1998. Compassion for humanity in the Jewish tradition. . Northvale, NJ: Jason Aronson.

Sharp, Liz, and Tim Richardson. 2001. "Reflections on Foucauldian discourse analysis in planning and environmental policy research." Journal of Environmental Policy \& Planning 3 (3): 193-209.

Sidney, Mara. 2003. Unfair Housing: How National Policy Shapes Community Action. Lawrence, Kansas: University Press of Kansas.

Simoes, Claudia, and Sally Dibb. 2001. "Rethinking the brand concept: new brand orientation." Corporate Communications: an international journal 6 (4): 217 224.

Singleton, Vicky, and Steve Mee. 2017. "Critical compassion: Affect, discretion and policy-care relations." The Sociological Review 65 (2): 130-149.

South Louisville Community Ministries. n.d. Compassionate Advocacy and Emergency Assistance for Neighbors in Crisis. Accessed May 20, 2020. Retrieved from: https://slcm.org.

Spectrum News. 2019. "Mayor Announces Funding to Help Homeless Individuals and Families." Spectrum News 1, 6 September: Retrieved from: https://spectrumnews1.com/ky/louisville/news/2019/09/06/fischer-announces-1-million-for-aid-to-homeless-and-families.

Spikins, Penny A., Holly E. Rutherford, and Andy P. Needham. 2010. "From Homininity to Humanity: Compassion from the Earliest Archaics toModern Humans." Time and Mind 3: 303-25.

Sriwimon, Lanchukorn, and Pattamawan Jimarkon Zilli. 2017. "Applying Critical Discourse Analysis as a conceptual framework for investigating gender stereotypes in political media discourse." Kasetsart Journal of Social Sciences 38 (2): 136-142.

Stanford Encyclopedia of Philosophy. 2020. Rights. 24 February. Accessed May 21, 2020. https://plato.stanford.edu/entries/rights/. 
Stanford Encylopedia of Philosophy. 2020. Rights. 24 February. Accessed May 21, 2020. https://plato.stanford.edu/entries/rights/.

Stoesz, David. 2002. "The American Welfare State at Twilight." Journal of Social Policy 31 (3): 487-503.

Stryker, Robin, and Pamela Wald. 2009. "Redefining Compassion to Reform Welfare: How Supporters of 1990s US Federal Welfare Reform Aimed for the Moral High Ground." State and Society 16 (4): 519-557.

Sznaider, Natan. 1998. "The Sociology of Compassion: A Study in the Sociology of Morals." Cultural Values. Jan1998, Vol. 2 Issue 1, p117. $23 p 2$ (1): 117-140.

Therkelsen, Anette, and Henrik Halkier. 2008. "Contemplating place branding umbrellas: the case of coordinated national tourism and business promotion in Denmark, Scandinavian." Journal of Hospitality and Tourism, 8 (2): 159-175. Thompson, John. 1990. Ideology and Modern Culture: Critical Social Theory in the Era of Mass Communication. Palo Alto: Stanford University Press.

Thompson, Michael. 2017. "Introduction: What Is Critical Theory?" In The Palgrave Handbook of Critical Theory, edited by Michael Thompson, 1-14. New York: Palgrave Macmillan.

Ticktin, Miriam. 2011. Casualties of Care: Immigration and the Politics of Humanitarianism in France. Berkeley: University of California Press.

Tronto, Joan. 1993. Moral Boundaries: A Political Argument for an Ethic of Care. New York: Routledge.

Trueman, Myfanwy, Mary Klemm, and Axele Giroud. 2004. "Can a city communicate? Bradford as a corporate brand." Corporate Communications: An International Journal 9 (4): 317-330.

UofL Physicians. 2016. LGBTQ Care. 21 November. Accessed August 29, 2019. Retrieved from: https://www.uoflphysicians.com/news-room/video-uofltoday-lgbtq-care.

van Dijk, Teun. 2001. "Multidisciplinary Critical Discourse Analysis: A plea for diversity." In Methods of Critical Discourse Analysis, by Ruth Wodak and Michael Meyer, 95-120. London: Sage.

Velzer, Ryan Van. 2019. "How Louisville’s Budget Reduction Affects Vulnerable Residents." WFPL, 26 June: retrieved from: https://wfpl.org/how-louisvillesbudget-reduction-affects-vulnerable-residents/. 
Vincent, Andrew. 2010. Modern Political Ideologies. New Jersey: Blackwell Publishing.

Vitellone, Nicole. 2011. "Contesting Compassion." The Sociological Review 59 (3): $579-596$.

Volcic, Zala, and Mark Andrejevic. 2011. "Nation Branding in the Era of Commercial Nationalism." International Journal of Communication 5: 598-618.

Vrasti, Wanda, and Jean Michael Montison. 2014. "No Good Deed Goes Unrewarded: The Values/Virtues of Transnational Volunteerism in Neoliberal Capital." Global Society 28 (3): 336-355.

Wagner, Sara. 2019. "Give A Day Impact: Pedal Power." WHAS11, 10 April: Retrieved from: https://www.whas11.com/article/news/give-a-day-impactpedal-power/417-1575920a-5483-47a7-87cf-0597a794405f.

Walters, William. 2010. "Foucault and frontiers: Notes on the birth of the humanitarian border." In Governmentality: Current Issues and Future Challenges, edited by Ulrich Bröckling, Susanne Krasmann and Thomas Lemke, 138-164. London: Routledge.

Weintraub, E. Roy. 1985. General Equilibrium Analysis: Studies in Appraisal. Cambridge: Cambridge University Press.

White, Richard. 2012. "Levinas, the Philosophy of Suffering, and the Ethics of Compassion." The Heythrop Journal 111-123.

Whitebrook, Maureen. 2002. "Compassion as a political virtue ." Political Studies ( Pages: 529-544 Published: AUG 2002) 50 (3): 529-544.

Williams, Bethanni. 2019. "Ali Week includes marking new branding, name of Louisville Airport." WHAS11, 6 June: Retrieved from:

https://www.whas11.com/article/news/local/ali-week-includes-marking-newbranding-name-of-louisville-aiport/417-0c04015a-7791-4a62-85c0c2c47c148fdb.

Wodak, Ruth. 2001. "What Critical Discourse Analysis is about-a summary of its history, important concepts and its developments." In Methods of Critical Discourse Analysis, by Ruth Wodak and Michael Meyer, 1-13. London: Sage. Wood, Lisa. 2000. "Brands and brand equity: definition and management." Management Decision 38 (9): 662-669. 
Woodward, Kathleen. 2004. "Calculating Compassion." In Compassion: The Culture and Politics of an Emotion, edited by Lauren Gail Berlant, 59-86. London and New York: Routledge.

Wuthnow, Robert. 1991. Acts of compassion: Caring for others and helping ourselves. . Princeton, NJ : Princeton University Press.

Yun, Hing Ai. 2010. "Service Workers: Governmentality and Emotion Management." Culture Unbound 2: 311-327.

Zenker, Sebastian, and Nicole Martin. 2011. "Measuring Success in Place Marketing and Branding." Place Branding and Public Diplomacy 7 (1): 32-41.

Zenker, Sebastian. 2009. "Who's Your Target? The Creative Class as a Target Group for Place Branding." Journal of Place Management and Developmen 2 (1): $23-32$. 


\section{APPENDIX A - OPERATIONALIZING CDA}

Fairclough's $(1989,1995)$ model for CDA consists three inter-related processes of analysis tied to three inter-related dimensions of discourse. These three dimensions are:

1. The object of analysis (including verbal, visual or verbal and visual texts).

2. The processes by means of which the object is produced and received (writing/ speaking/designing and reading/listening/viewing) by human subjects.

3. The socio-historical conditions which govern these processes.

According to Fairclough each of these dimensions requires a different kind of analysis:
a. text analysis (description),
b. processing analysis (interpretation),
c. social analysis (explanation).

CDA involves three analytical categories: Genres, Style and Discourses (Farrelly, 2010). Genres are referred as various ways of linguistic interaction that has specific forms and structures derived through social and institutional context (Fairclough, 2003; Boyd \& Monacelli, 2010). Genres are bounded in social practices, conventions, rules, and norms that governs certain type of communication (Wodak \& Meyer, 2009). CDA analyzes how different genres are used in social and institutional context to legitimize ideas, policies, and rationalition (Chilton and Schäffner 2002). In the context of the research question, an analysis of genre through the CDA method helps to understand how the discourse of compassion is carried and engineered. The second analytical focus of CDA is 'style', which is the way language embodies identity and personality (Fairclough, 1999). In respect to our investigation, we can 
inquire the nature of identities that are being created and embodied through the discourse of compassion. The third focus of CDA is that of discourses, which investigates the epistemic world that is formed through the use of discourse (Fairclough, 2003). The analysis of discourse involves abstracting the underlying rules, norms and practices that govern the language of the discourse (ibid). In respect to the research question, a focus on the discourse of compassion within the text will identify the themes of social life that are being produced through the discourse and the underlying perspective that is driving the discourse.

Fairclough's analytic framework is constituted by three levels of analysis: the text, the discursive practice, and the sociocultural practice. In other words, each discursive event has three dimensions: It is a spoken or written text, it is an instance of discourse practice involving the production and interpretation of texts, and it is a part of social practice. The analysis of the text involves the study of the language structures produced in a discursive event. An analysis of the discursive practice involves examining the production, consumption, and reproduction of the texts. The analysis of sociocultural practice includes an exploration of what is happening in a particular sociocultural framework.

\section{Reflexivity and Positionality of the Researcher}

Chouliaraki and Fairclough (1999) cited reflexivity as an important part of CDA research. Sharp and Richardson (2001) and Sidney (2010) argue that CDA researchers should acknowledge their own subjectivity in selecting the research topic, collecting data, and interpreting results. Myerhoff and Ruby (1982) define reflexivity as "structuring communicative products so that the audience assumes the producer, process and product are a coherent whole ... scientists have also been engaged in 
reflexive activities ... scientists continuously test their own assumptions and procedures" (pp. 6-9). It involves monitoring the analytic frame and the ontological position of the researcher.

My positionality comes for this research comes from my professional, academic, and personal background. I am an international student pursuing a doctoral degree in Urban and Public Affairs at the University of Louisville. This required me to live in Louisville for the last four years. During my stay, I witnessed the narrative of Compassion Louisville being evoked by a number of political actors in the city, including the mayor. I have also witnessed various political struggles in the city that used the language of compassion to make claims. I have also been part of the volunteer group that advocates for the value of compassion in the city. I have been intrigued by this use of the language compassion in politics and found it unique to Louisville. These experiences drew my interest in choosing the research topic of understanding what Compassionate Louisville does.

The analytical lens used in this research has predominantly been a critique of neoliberalism. I have analyzed Compassionate Louisville as a governmental tool whose motive is to have discipline emotions of the people in disguise of humanitarian language. I have argued that the discourse of compassion deploys a new logic of exclusion where care is deployed according to the rationality of 'legitimate' suffering. It displaces the political rights of marginalized communities and creates new forms of subjectification. This positionality comes from my academic training in this $\mathrm{PhD}$ program that shaped my ontological positions of post-structuralism. It also gave me a normative position against the structure of global capitalism and neoliberalism that produces and reproduces social misery. 


\section{APPENDIX B - RESOLUTION OF COMPASSIONATE LOUISVILLE}

\section{SCAN COPY}

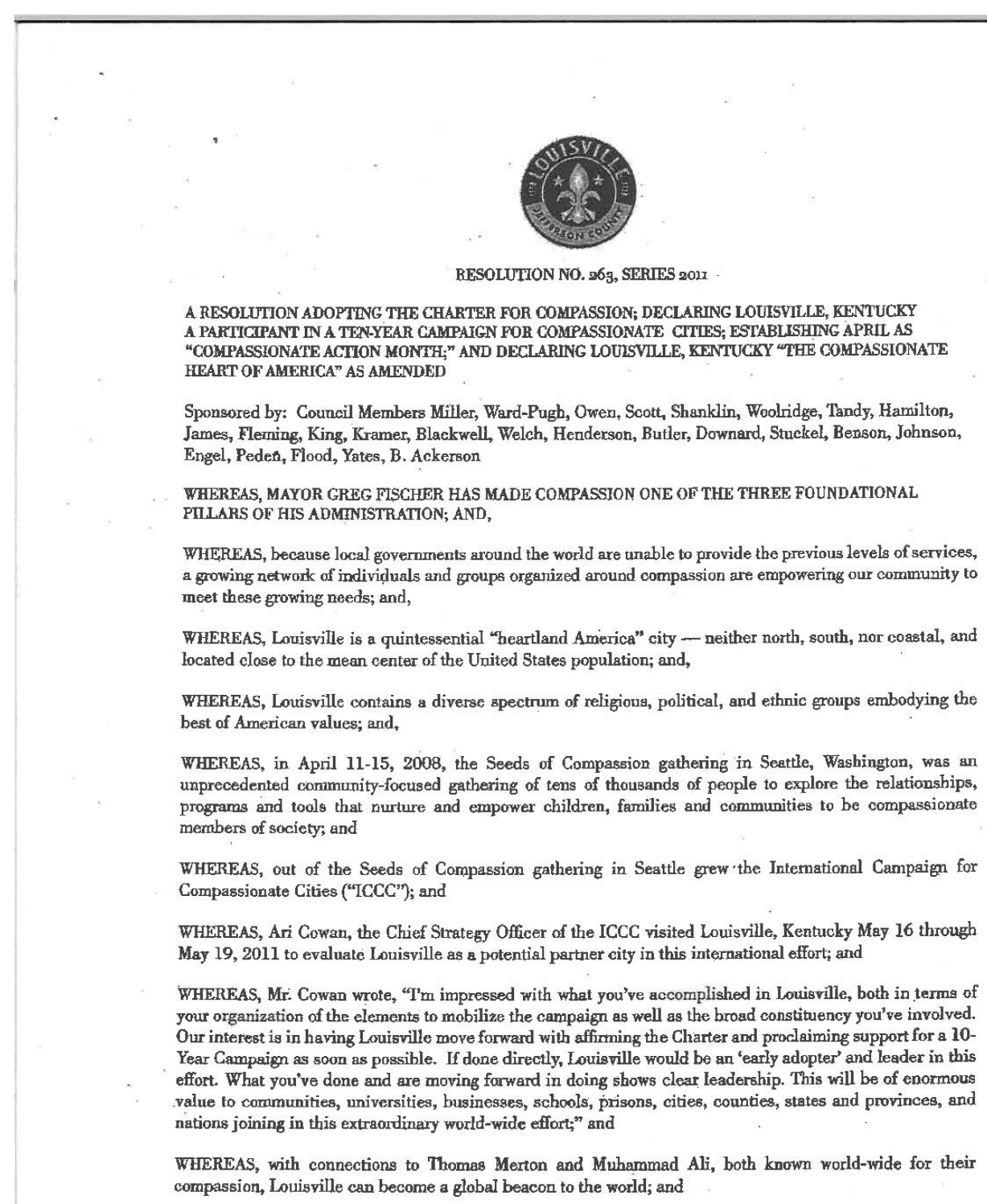


WHEREAS, Louisville is infernationally known for its leadership and innovation in the continuing effort to promote the values of justice, equity and respect for all peoples through organizations such as the Center for Interfaith Relations and its Featival of Faiths; through the Ali Center and its global outreach; through the Merton Institute for Contemplative Living; through Interfaith Paths to Peace and its extensive programs; through EDGE Outreach, empowering ordinary people to provide clean, safe water to people around the world; through the area community ministries which are a model for the nation; through USA Harvest; and through individual and organizational efforts too long to list; and

WHEREAS, we acknowledge our role and responsibility to make compassion a clear, luminous and dynamic force in our city and through educational efforts and deliberate actions; and

WHEREAS, there are still many instances where individuals and groups fail to live compassionately and thus we acknowledge we must recommit to, and broaden, this effort in all places of the community.

WHEREAS, be it resolved by the Council of the Louisville/Jefferson County Metro Government as follows:

SECTTON I: THAT the Louisville Metro Council and the Mayor of Louisville affirn the Charter for Compassion (attached hereto) and extend the Charter to include Mother Earth and all of Her iohabitants, including animals; SECTION II: THAT Louisville declares a Ten Year Compassionate City Campaign and hereby expresses its desire to be a lead city in this effort;

SECTION II: THAT April is designated Compassionate Action Month in Louisville;

SECTION IV: THAT Louisville, Kentucky is declared the Compassionate Heart of America;

SECTION V: THAT Louisville welcomes guests from all around the world to learn about the commitment to compassionate action that exists here;

SECTION VI: THAT all citizens of Louisville are encouraged to affirm the Charter for Compassion and to strive to live and act more compassionately; and

SECTION VII: THAT this Resolution shall take effect upon its passage and approval.

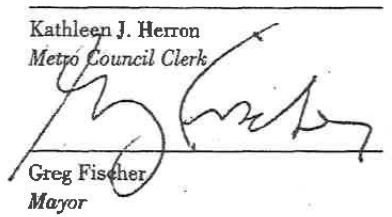

Jim King
President of the Council

Approval Date

\section{APPROVED AS TO FORM AND LEGALITY:}

Michael J. O'Connell
Jefferson County Attorney

BY: 


\section{APPENDIX C - VISION, MISSION AND VALUES OF COMPASSIONATE LOUISVILLE}

According to the website of Government of Louisville, the following are the Vision, Mission and Values of Compassion (City of Louisville 2011).

Vision: A community and world becoming more and more compassionate.

Mission: To champion and nurture the growth of compassion. We ask: 'What does compassion want for Louisville?'

\section{Values}

Compassion. This is the shared purpose and principle. Compassion is common ground and a unifying force in our polarized world. Compassion impels us to work tirelessly to alleviate the suffering of our fellow creatures, to dethrone ourselves from the center of our world and put another there, and to honor the inviolable sanctity of every single human being, treating everybody, without exception, with absolute justice, equity and respect. Compassion is the bridge between internal practice and external change.

"Compassion asks us to go where it hurts, to enter into places of pain, to share in brokenness, fear, confusion, and anguish. Compassion challenges us to cry out with those in misery, to mourn with those who are lonely, to weep with those in tears. Compassion requires us to be weak, vulnerable with the vulnerable, and powerless 
with the powerless. Compassion means full immersion in the condition of being human." -Henri Nouwen

Beauty. Compassion calls for a beautiful morality. It seeks to see the beauty in what is, and to incorporate the shadow. If a morality has beauty, it is compassionate.

Inclusion. Anyone and everyone who commits to compassion is welcomed.

Empowerment. This campaign is about empowering people to make a difference in their own life and the lives of others. Compassion is not pity.

Transparency. There is no political agenda. This effort exists to enable compassionate living to help the citizens of our community reap the benefits that come from living a compassionate life — which are many.

Universally Positive. "The best criticism of the bad is the practice of the better." -St Francis of Assisi. This effort is solely designed to advance compassionate action and will have no opinion on outside issues.

Social Innovation. Individuals and groups are free to embody compassion in their own ways. Social innovation is encouraged.

Paying it forward. Anyone who participates "owes" no one anything other than to "pay it forward." People are encouraged to participate simply to experience first hand the thrill and joy associated with compassionate living.

Hospitality. We will welcome guests in the name of compassion. Local, national and international guests will be encouraged to come to exchange ideas and practices.

Abundance. What we have is enough if we share and if we allow it to flow. We have the capacity to provide what we need in the face of the human condition. 
Awareness/Understanding. We strive to keep compassion in our daily thoughts and practice, and to understand the meaning of compassion and its relation to charity, justice and good works. We become increasingly aware of how we practice compassion and of opportunities to grow our practice of compassion.

Intention. We make a conscious choice to continually grow both our commitment and capacity for compassion. Our commitment to compassion moves us to practice compassion where we are able. 


\section{APPENDIX D - MAYOR'S GIVE A DAY PROJECT}

Metro United Way supports the volunteer engagement platform for the Mayor's Give a Day by connecting those who need help with those who want to help (LouisvilleJefferson County Metro Government 2019). The projects and initiatives in 2019 includes:

- Return of Build a Bed on Saturday, April 13. This AmeriCorps-sponsored effort builds beds for children who otherwise don't have one. With support of nearly a dozen local companies, including K\&I Lumber, this project provides a bed, bedding, books and stuffed animals - some of the basics of a good night's sleep.

- Thousands of volunteers will join together on Saturday, April 13 to pick up litter and beautify the city through the Brightside \& Passport Health Plan Community-Wide Cleanup, one of the largest Give A Day service projects.

- WE Day Kentucky will be celebrated by more than 2,400 students and adults on Tuesday, April 16 at The Kentucky Center. This is the organization's 7th annual event, representing $400+$ schools from across the Commonwealth, contributing $400+$ service hours valued at a social impact of $\$ 10$ million. This year's goal for the students is to collect 100,000 personal care items for students in need. In addition, students and the business community will take part in the annual WE Walk for Compassion that afternoon. 
- The American Red Cross' inaugural Mayor's Give A Day Blood Drive on Wednesday, April 17 from 10 a.m. - 3 p.m. at the Kentucky International Convention Center. Make an appointment by visitingRedCrossBlood.org and enter sponsor code: GiveADay.

- Random Acts of Kindness, a nonprofit started by Jefferson County Public School student Andrew Dunn, will be joining Barrett Middle School students on Thursday, April 18 to make 3,000 burritos to be donated to a local food pantry.

- Metro Parks, Louisville Parks Foundation, Great Lakes Brewing and Coca Cola are teaming up to plant trees on Arbor Day, Friday, April 19.

- Pedal Power and Kentucky Refugee Ministries are back for another year to give refurbished bikes to refugees. Bikes will be delivered to various locations throughout the week. 


\section{APPENDIX E - SUMMARY OF CITY BUDGET ALLOCATION FOR}

FISCAL YEAR 2020

(Louisville Metro Government 2019)

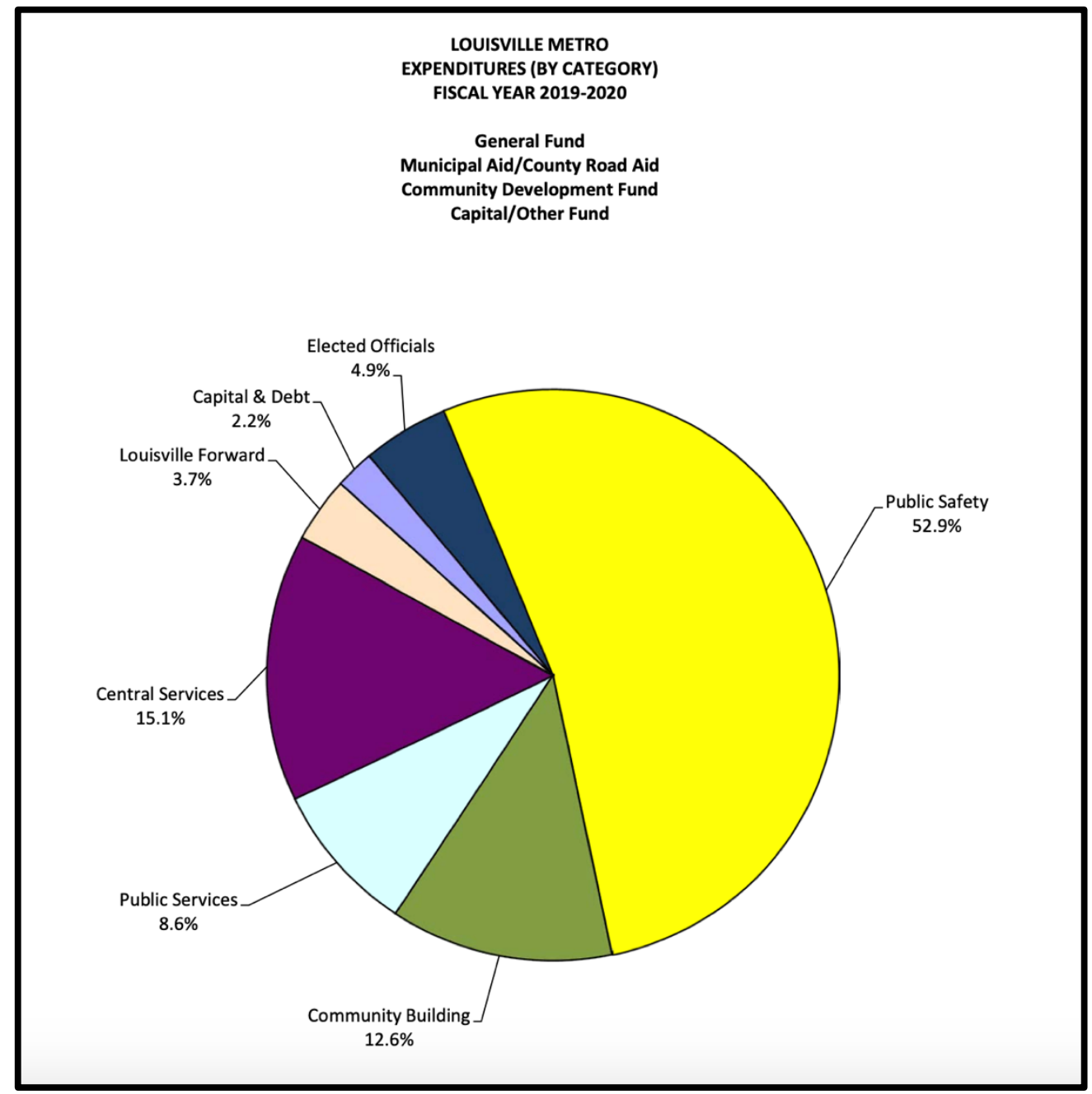




\section{APPENDIX F - INTERVIEW TRANSCRIPTS}

\section{Interview Code: 01}

Interviewee Coder: 01

Date: February $20^{\text {th }} 2020$

Location: Office of the interviewee; Louisville

\begin{tabular}{|c|c|}
\hline Question 1 & $\begin{array}{l}\text { How would you describe your role in the making of Louisville, a } \\
\text { compassionate city? }\end{array}$ \\
\hline Answer: & $\begin{array}{l}\text { Oh, that's a really good question. I was a contact point for representatives from } \\
\text { the city who had heard about this program and contacted me about it. } \\
\text { And I provided some guidance and so on with that, and then traveled out here to } \\
\text { work with him because the only requirement at that point was to have the mayor } \\
\text { and the City Council, affirm the charter for compassion, and then have } 10 \\
\text { months to develop a comprehensive plan for implementation. As the director of } \\
\text { the International Campaign for Compassion Cities, Louisville came early on in it } \\
\text { the second city was basalt, Colorado. }\end{array}$ \\
\hline Question 2 & Was not the Seattle the first city to affirm to Compassionate City? \\
\hline Answer: & $\begin{array}{l}\text { Seattle was first city,Colorado was second. I think Louisville may have been the } \\
\text { third. I'm not sure there may have been some others but Louisville, of course, } \\
\text { much larger city and so on. } \\
\text { So my job was to provide advice and about what the requirements were and so } \\
\text { on but I didn't have anything to do with the organization of it here or anything } \\
\text { like that. }\end{array}$ \\
\hline Question 3 & So you represented the Charter of Compassion? \\
\hline Answer: & $\begin{array}{l}\text { Yes. I provided the Charter to them. } \\
\text { But we had a set of guidelines about what they had to do with their City Council } \\
\text { and their Mayor. And then a set of specifics about what would be involved if } \\
\text { they were certified. That generally we use the program of } 10 \text { months to come up } \\
\text { with a comprehensive plan for implementing strategies and programs for putting } \\
\text { compassion into practical form in the city. } \\
\text { That later was cropped by the compassion Action Network. They said that they } \\
\text { wanted to drop that because it was making it too difficult for the cities to be } \\
\text { Compassionate Cities. And while I disagreed with that, there's a point that, in the } \\
\text { early stages, it made easier for many, many cities. } \\
\text { So we had to do is just pass a resolution and have the mayor affirm it, then they } \\
\text { they had it, got them into the into a program with it. So there were advantages in } \\
\text { what they were saying. } \\
\text { But I felt that they needed to have some kind of tangible, measurable results. } \\
\text { Because the original idea I had for this was that it was based on the Public } \\
\text { Health Foundation where you had research demonstration projects. And that's }\end{array}$ \\
\hline
\end{tabular}


what we outlined to do a small demonstration project to see how it works and how you get buy in and go from there.

\begin{tabular}{l|l} 
Question 4 & So, the Compassion Action Network is now the Charter of Compassion? Can
\end{tabular} you elaborate more about Charter of Compassion?

Answer: Yeah. Well, I know mostly about what happened with the development of the international campaign from, like I've got here came out of the seats of compassion event in Seattle. And so let me take you through that real quick.

So in 2008, they had a big thing at the Kingdom, the big football stadium. And it was on I think of a Simulcast on the on the internet. And it had the Dalai Lama, Desmond Tutu, you know, Governor of the state of Washington, he had all these people.

And over the days, they had about 154,000 people attend. And even China had a plane flying overhead with the thing talking about how bad the Dalai Lama was. So it got quite a bit of press. And went there. I mean, I had no official capacity. Went there because as one of the 154,000 . Now this is cool. And then apparently, as I understand it, they said, okay, we had this and this has been very successful, it was very successful. And they said, Well, what do we do? We should continue it in some form. And so a group of people got together. Number people from the technology sector and activists, not me, and decided to start the compassion Action Network.

And it was before Facebook really got going. But they had a thing called Ning, which was, it was like a thing you can create your own Facebook thing where you can exchange things and post documents. And so they had the Ning site on it, where they had people come in. So that was going on. I didn't know much about that. I was working on other projects and then In 2009, I was approached by John Raymer, who was the acting director or head of the Compassion Action Network, about how they want to get help about organizing and everything because I'd had some experience and I had raise funds for a number of different groups.

And so I met with him in October 2009. And went over about, you know, what have you got, what is your product? Part of the problem, they were suffering was that people got very enthusiastic, they join the Ning site, they go up there and they exchange ideas, but after about a week, it was it didn't do anything.

So I kept asking him, so what is the service that you're providing to people and they needed to work that out. So I think In, I can't remember it was 2008 when Karen Armstrong got the TED Prize for the Charter for Compassion.

So in 2010, and I think was largely led by John Ramer, who's now the head of the compassion games, as I understand it, and that he decided because he had contacts in city government and so on, to see if the city would, affirm the charter through the city council and the mayor. And it did. And he thought, well, this is really great, you know, see how it's a very liberal area that Karn Armstrong heard about it. And she on her own dime, flew out to Seattle, for the big event for it, so she was there. And that was on April 24th of 2010. I attended that as well. I'd been asked that the next day, the 25th, which is Sunday, if I would speak at a fundraiser at Yaffa Margaret's house. Yaffa is married to Paul Maritz who is number three of Microsoft and is the President I think of VMware. So and they're quite wealthy, and it was at their home on Mercer Island and then that they were getting people together and they wanted to raise a few hundred dollars for the tank for C.A.N and Karen Armstrong was there. So I made a presentation they apparently raised substantially more than a few hundred dollars and Karen armstrong. Well, the next day, they were going to have a dinner with Karen Armstrong and the luminaries of something and Armstrong insisted that I be there. And so I sat across from her at this restaurant and she would fly out right after the dinner and she asked for suggestions about what should happen next. And I talked about, well, what you've got is product here. 
And you could do an initiative that you could have an international campaign built on a public health model for you. And I explained it to her, there's four steps in it, you do a demonstration project, you modified that, then you do a larger project. And you have to go through this process of evaluating and coming back and modifying and then I said that you could have certification requirements recognition awards program, and a very heavy educational component, because there's a lot of misunderstanding about what compassion is what it does. And she sounded really enthusiastic and so on. So she left but from that she had apparently talked to the Fetzer Institute, which is in I think, Kalamazoo, Michigan, and I'm pretty sure and they wasn't solicited, but they were going to Provide a $\$ 200,000$ grant to build an international campaign for compassionate cities, and that I was to be retained to direct the program. And one of the things was that there is some misconception that I came up with the idea. Actually, I think several people came up with it at the same time, I wasn't aware that john raymer and Pam Kilburn Miller also talked about we should do something, you know, with other cities. So, people saying that I originated, the idea, I think is is not correct. I think a whole bunch of people saw the obvious implication of Seattle, why not somewhere else.

So, and that was in April. So in September, I had signed a consulting agreement to develop a strategic plan, you know, as an independent consultant for compassion Action Network. Then the following month, I got an consulting engagement to work for the compassion Action Network as a chief strategy officer to help do that in a consulting capacity. So that, you know, I built them and everything was in employment. And then around the 15th of that month, we learned that Fetzer had approved $\$ 200,000$ grant for the International campaign for compassionate cities, which shocked us. We didn't know Karen Armstrong was doing this. I had been invited to down to a meeting in downtown Seattle. They said, well, you just need to be there. And I said, Okay, so I went down there. And Jillian ganda, who's a program manager at, and her name's mentioned in my notes here, came down and said, This is what we want to do and we want him to the fund Aryan developing this and it was really startling and very encouraging. And there they were going to start with a distribution of 85 thousand dollars. And so I went to work on that. And then the following month I was invited to go back and I gave a presentation on compassionate urban governance at the United Nations based on this program because I laid out a whole program about what should happen and how you need to evaluate the nature of suffering in your city. And in that kind of, so I spoke at the UN, and it was part of a big Ted Talks, those guys a big event there. So that was intimidating.

So then, the following January, I got this out of an activity report that I got, I completed requirements for as second phases of Fetzer grant, we received additional $\$ 20,000$ out of the 200,000 and then in March, I work with Gillian program manager and we were in bi-weekly phone calls, and we were developing a selection of members for the International campaign for Compassionate City's advisory board, which we wanted to get input from people and then we establish a page placeholder web page, which just didn't have much on it, but it later you know, we populated it. And that was for the International Campaign, and then we got city to sign. And we had the two requirements, which is known here in the back on page two, city government governance. Mayor, city manager, plus city council affirmed the Charter for Compassion.and within 10 months and that was flexible if people need to take more time or they wanted to quick refine. The city submitted comprehensive plan for identifying areas of suffering and action points, including timeline to address the suffering. And then we looked at courses designed for assisting in the process of developing fantasy initiative. We had a whole list of courses that we do, and would use wet web teleconferencing to provide them. And then I traveled up to basalt Colorado in March to verify the city and support their participation. Second, confirm city and I liked it because they're small town In 
Colorado. And I thought, well, this is great. We have Seattle, which is a major, major metropolitan area. But we want small towns to do to do this, too. So this worked out really good. And then in April, and may, I traveled to Louisville, to meet with Mayor Fischer and Metro city council to finalize and I'd come out a couple of times before participation in international campaign. And then there was a local organization that gave me the national Peacemaker of the Year Award for this work, and there and then, but Louisville affirmed it and we got going, they're already doing this give a day program Which I thought that's great and add to that and analyze what communities are having needed to work with groups and so on. And then on August I completed that and deliver the strategic plan to the camp and it was approved by the board of directors.

Then in 2012 there was a big fundraising luncheon. I don't know if you've ever been to one of these they have a big presentation in the ask and they have people that tables they will How much are you going to contribute? And I mean, a lot of times when I spoke at for youth group raised like $\$ 130,000$ for the lunch so that you know, it's for several k. And so it was at the Sheraton Hotel in downtown Seattle corner on from flew out Howard Bihar. I think he was the president of Starbucks at the time birth, immediately past president and a very yet Number of other people. I had, as part of the campaign said we should have an annual recognition program and a fellow I think it's the estate of jack Olive was a fellow from Seattle University. I believe that was a connection. Neil was his wife put up money for an award program and a Louisville got an award. And, you know, there were a couple of other groups got awards for doing compassion committee and contributing to the city. The awards program was to recognize people also raise visibility and to get people enthusiastic about that. And then I got a revised strategic plan and delivered that to the board of directors.

So on the 31st of May, my consulting agreement ran out and I was up for going back. But they had expended all the money and they had no funds, at that point to say it subsequently got funds. And they had decided that they would. Earlier they had decided that they wanted to eliminate the need for having any requirements. They wanted to get rid of the awards program. All they wanted was people to firm the charter for compassion. And that was it. And that's not something I agreed with. I could see the benefit of it in some respects and I'd become very interested in compassionate organizations and organizational systems. And I had colleagues from England other place, said, I'm really fast. And not just cities, but healthcare systems and businesses and so on. So I decided, they said, Well, we talked about me renewing, and then I would raise some money. I thought, well, I think I'm gonna take the pass because it's going in the direction it's going science, not my interest is in these other systems. And so, so I didn't renew.

And then within several days I initiated because I got pressure from all my friends. Said let's get going on this was called the International Working Group on compassionate organizations. So I thought we would just have group when we talk about this and we figure out stuff do we want to publish some stuff and so on. And it took off and all of a sudden, it was way too big. So as you know, geez, we have to have a website. So I got a website, and we started getting All these people saying, well, you want to look at this and I say, we got to connect all these people like Jim dodi's group at Stanford and so on. There's some really cool things going on. And I really got a gauge to that. But during the months following, I ended on the 31st of the last day of the month in May. Months following there were, continuous talks, he replaced the executive director, and continuous talks about me coming back, and I said, I'd be happy to help out, but I don't want to come on board and be a staffer. And that's not what I want to do. And I was asked if I would do a presentation in London at the empathy and compassion in society conference in London, in November about compassionate cities. And I said, Sure, I'll go back then on behalf of compassion Action Network and talk about that. So in the end of November, the 23rd, I went back 
for the conference in London did a presentation that was on some panels. And then I had a day before where I spoke to high school students, they brought them all together. That was fun. I liked doing that.

And then I returned. And when I was there, I got an email from Andrew Himes, who was the new executive director, I guess would be his title at compassion Action Network proposing that that we put the international working group together with the National Campaign with CAN and his proposal was that we turn over all our assets to them, that we raise a half a million dollars for CAN me and the people I've worked with, and that I would be a lead candidate for position of running the international compassionate organizations thing. And some people got very angry about that. I thought it was fairly funny. It's like, let me get this straight, your offer to me, as I turn everything over to you, I raised a bunch of money for you, and you may give me a job. You know, I already have a job. I just keep the money within what we're doing if we were doing that. So I wrote to him, I said, When I got back that this is a very I had an attorney to look at your offer and I spoke with my colleagues and we're going to decline it but we're open to talking further down the line about how we might collaborate. And I got a message from him that that CAN no longer supports. We had, we had pro started to do a planning of program, international summit conference and compassionate organizations to be held here in Louisville at Spalding University. And he withdrew the support of can and told me I was not to mention current Armstrong's name in any of our publications, which she's speaking at our conference. And then, it got nasty. I won't go into details about some of the things that were pulled in it was, I'll tell you one that I had taken ill and that I was going to have to retire and I was going to turn everything over, and that's fine. So there was a lot of that and to be honest with you. I saw this in the environmental movement, where there was a sort of jockeying for who's going to be the top, who's going to be the star, saw this in the civil rights movement. So I didn't take it personally. I mean it just some of this comes off as sort of the chaff when you're harvesting the stufff. It was disappointing. And Dr. Curtain can fill you in he was on a phone call we've retained 1400 we had a membership program for the International Working Group. Well when we became the International Center for convention organization we had we had a membership from so you could sign up and join us a you know, regular members student member whatever and then you click on it send it. we got we didn't keep any the ones with really gross obscenities but we have in our files 1400 applications that were all the phone numbers are always going 1234567890 that's my phone her phone number Your name is go to hell, you guys and seven and they had used a VPN so they were coming from Bulgaria and China and stuff but they were using a VPN and that stopped and it could be a coincidence when Andrew Himes was sacked as the thing so it was it had its ugliness in it. There is a competitiveness and stuff in it, just sort of what comes with it. So we conducted, we put together this international summit conference here, Which did fine. And we had Armstrong come by teleconference to the conference and held at Spalding University. We also had a summit for leadership about how we can cooperate. And cans proposal is that all the organizations be merged under can and nobody wants to go for that. So Chris irons from the compassionate mind foundation and others were there and we declined that. that was on May of 2013. In late September 2013, I arrived here to establish the International Center for compassion organizations with Dr. Curtin and Tony beelack and some other people and we were housed here at the university upstairs by the classroom that standard that in the office that was right next to it was mine and Tony was the university's ombuds and then was also the associate director general which he still is. So by going, from the international campaign for compassion cities, to the International Center for compassion organizations, which is a $501 \mathrm{c}$ three federally recognized public charity, we're able to then apply this whole public health approach and educational approach and so on. And that's, that's what we're doing right now. We're focusing on getting books out as part of the things and working really hard in it. So that's, that's the background and then these 
documents I gave you were all ones I developed and stuff that on the international campaign so that's it, so it has, it has its ups and downs has any of this stuff so that's.

That's the divergence and I'm not sure I haven't stayed current with what the charter for compassion is doing. I'm concerned that it's an Abrahamic religious document, and which is fine, but I don't know that it's that inclusive. a group that I more strongly identified with is the compassionate mind foundation United Kingdom under Dr. Paul Gilbert, from the University of Darby. And their work is just spectacular. And they're evolutionary psychologists, and their fellows ofthe International Center we have a list of fellows that supported our work and who we support. And I really am in agreement with what they do about tribalism about what happens to people when they're disempowered. It's very difficult to be compassionate when you're under the thumb of something disease or war or whatever else. And then they are the convention mind foundations and one of those organizations that hasn't been caught up in this whole what I call glamour trap. Who's going to be the savior of the world and be the star compassion person. They don't care. Paul Gilbert has supported very many other people who have worked with stuff in ideas in the compassion area. When new things come out. He jumps in there to congratulate them and creates him and he connects him with people. And I think he's a very good example all those people that are watching wonderful to work with. And they were started, I think in 1996 when he began doing this, and they now have a foundation, which is like a US charity in England, full of resources, they conduct conferences largely for mental health professionals. So they're a big presence in Australia. I have work with our colleagues who are part of the compassion mind foundation in Greece and France and Scotland and Ireland in England and Australia and stuff. So they really are, are putting it into practice without having this. Problems with competition or the sort of amateurish feel good. Pat, everybody in the back. I mean, your observation about compassion is an alternative to rights. I mean, They would go crazy about that they love that because that's true there. It is compassionate be used that way. And when I first proposed compassion bypass, I thought, boy, they're going to really slam me for this. And they say, No, no, that's go ahead with that, because I talked about when, the motivation behind it is, and one of the things I've been criticized about is having compassion for people who do bad things. And what I try to make the distinction of is the difference between the compassion for the human being compassion for the behavior, or have compassion for the behavior. So, Donald Trump have compassion for him. And because we have to ask, with all these things that happened among human beings, whether it's environmental degradation or crime or discrimination against immigrants and so on. So what happened to the people that are causing trouble in this area? You know, you go to a nursery, who are the offenders at a hospital you look at little babies They're not there. So, anyway, so that's it.

Question 5

Answer:
Why do you think Louisville chose to be compassionate?

That would be better a question to direct towards them? I think it for me in my estimation, I don't know what the situation is for Louisville. The people that I was exposed to like in the case of basalt, Colorado, it was what I experienced here was an authentic desire to improve the lot of people. They have a lot of immigrants. And I'm trying to think of where they came from if it was Italy because of mining, because they've been mining, and they have a lot of Latinos in there. And the police chief, there just he had taken up this thing about they had an enclave, you know, where the Latinos were. And he would, he would go down there himself and talk with them and tell them, hey, look, you know, some of you may be here illegally. That's not my issue. I'm not looking for illegal immigrants. But when you're driving, stay within the speed limit, because you're going to have less hassle. And if you are illegal, somebody may get up to that. And so and you can come to us and talk to us about what you need. And if you want to learn English, that's not a police department issue, but we'll put you in 
contact with people to help you do that. And if you have any problems we're here to work with you and serve you. And I talked when I was back, I talked to representatives from the Latino community. They love this white police chief, you know, because he was that way. And the mayor was that way and the City Council was that way. And they and it was the people who would push this Were school kids, that they wanted their city to be a compassionate city. so the one of the ministers said, well, it's your idea, you need to make a presentation to the city council. And they did and the City Council somewhat tearfully accepted and cheered them and they said, yeah, we want to do this. And they were a big example of this and I really wanted to push this. But the argument I got from the board at Can was they're just a small town that you know, we really need to get the big that's for most people aren't. You shouldn't be investing A lot of time and, and a small town so. So that's one motivation.

There are other ones where I'm not sure but I could see where it would be politically expedient to promote compassion, the fact that we signed the charter for compassion in Louisville, before it was a compassionate city, the Mayor Fischer when he was running for office made compassion one of the three pillars of his campaign. So he seemed to me to be the real deal. And Tom Williams, who's with compassionate louisville, and we've had some issues with him. But you have to look at his background and he had gone back to where Martin Luther King had stood At on the Lincoln Memorial and gave his I Have a Dream speech. And he's the one who managed to get Congress to put a marker where King stood to commemorate that. And that to me is that's pretty cool. That's pretty indicative.

The danger any group has is what I call the glamour hook. We can all start thinking we're saviors, and we got to be very careful about that.Because then you get into compassion bypass where the purpose of compassion is to build up your own reputation and so on. So I think the mayor was, and I would guess is probably still very sincere. So you can have the sincerity, but you can also have a lack of understanding what compassion is, the full nature of suffering, an approach to do it. so when I got back here, with the ring with Tony, when we open up here, we were doing community trainings which people in government that do the social work and stuff really loved. And we brought community leaders together, we train them in conflict resolution and how to identify stuff and so on. But we also got pushback from people saying, you don't have any right to do this. There are other people that should be doing this, not you. And so we, we made the decision to not focus in Louisville, but really focus internationally, because I think we were causing too many problems. So we, you know, we developed a diagnostic protocol for this and I don't know if you seen this.

This is where you look at the five bodies, I can send you this. And so with a city, you can look at any kind of organism. You can look at individuals. You can look at communities, you can look at families, you can look at institutions, hospitals, city government, and you say, the baseline and so what's happening to them physically? are they safe? Are they shelter? Are they getting physical nourishment? Are they physically healthy? Are they getting appreciation and love? This is a very soft thing, but it's a very real thing. We know what happens to Romanian orphans when they didn't get touched or love. They have very stunted brain development. we don't mean it in a real kind of saccharin, sugary way. I mean, it's just as a public health fact. Self beliefs, self fetters, acceptance. Are they being included? Are they being excluded because they're immigrants from Mexico or they're Muslims or something? Are they getting knowledge Are they having to deal with ignorance? Or are they eating meaning valued justice and happiness? Then we go up to the emotional, are they safe emotionally? are they safe to feel what they feel and explained? Are they sheltered? Are they allowed to see it just goes down to this track in all these five bodies. And we found this to be very useful for what we wanted to what we wanted to create. So and I'm not sure anybody's doing that with compassionate city. So it's going through and saying, Okay, well, where's the suffering? And some places I saw, 


\begin{tabular}{|c|c|}
\hline & $\begin{array}{l}\text { they didn't want to talk about suffering, it's too unpleasant it was really negative. } \\
\text { And that's what compassion. Compassion is about. }\end{array}$ \\
\hline Question 6 & $\begin{array}{l}\text { So when you say that without the action plan, just affirming to the charter, } \\
\text { would you say that that leaves the compassionate city of Louisville? Just like a } \\
\text { city brand? it's just an image? }\end{array}$ \\
\hline Answer: & 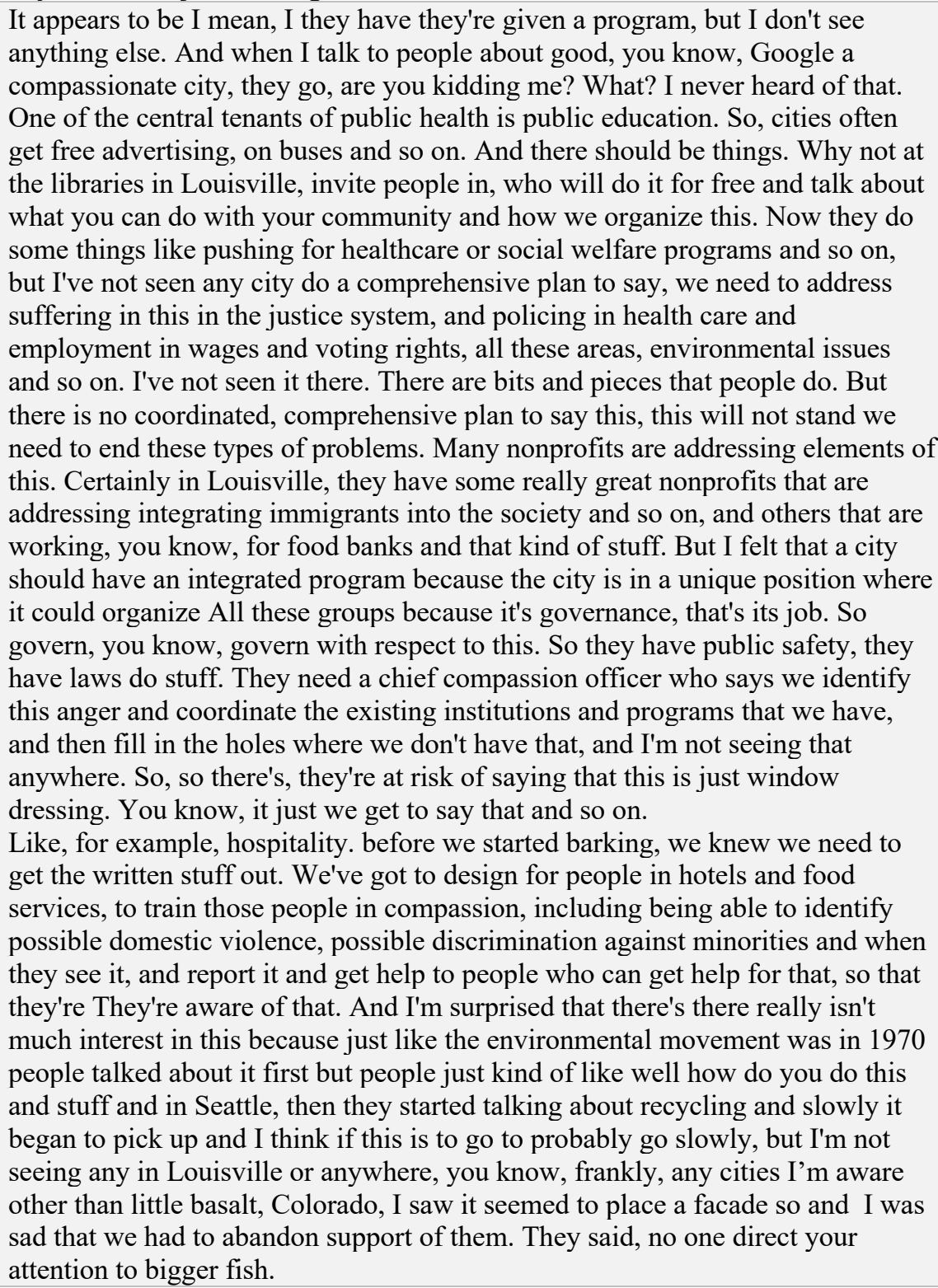 \\
\hline Question 7 & $\begin{array}{l}\text { So how do you think Louisville is being benefited? What's your opinion about } \\
\text { How Louisville is actually benefiting from? Because every time the mayor } \\
\text { speaks, he speaks about compassion city }\end{array}$ \\
\hline Answer: & $\begin{array}{l}\text { Oh, it's I it's an it's a superb PR thing, especially when there is suspicion of } \\
\text { government generally among people, especially in conditions now. And it drew } \\
\text { the Dalai Lama here. That was a big PR piece, the Association of cities, } \\
\text { whatever, they really featured it so showcase. So politically, it's a very astute } \\
\text { move. And I think as part of winning hearts and minds, it's great. And there may } \\
\text { be great intention there. There also may be a lack of knowledge of how to really } \\
\text { do it. I mean, you can have an increase in technology jobs, or we're building } \\
\text { bigger buildings downtown, so on and so forth. But that only addresses a small } \\
\text { portion of the spectrum of human behavior in the city. I've always thought, } \\
\text { Mayor Fisher's very genuine and supportive in everything. And I've met mayors } \\
\text { I won't say from where I went to fight the fight these guys just gonna pump it for } \\
\text { all it's worth that he or she can get out of it. And you know, but there are places } \\
\text { there. }\end{array}$ \\
\hline
\end{tabular}


There is a Mayor of Manitoba. It's a little town. Oh, I can look it up and see, but he had all the police training on compassion. He built many homes for all the homeless people. They did it and Olympia Washington, they've done it in Los Angeles, they've demonstrated that if you can get them an address so they can have an address so they can get work, and that they have the shelters, you can rotate people out of that they can have that they're safe in it and so on. And the fellow that was in it's a Native American name, I have to look it up. But he built it because he found that it was cheaper than having to incarcerate them or sweep them off the streets or pay the public health stuff and so on. He was very definitely compassionate. But he could demonstrate it in terms of Finance. And that's the thing too, as we can demonstrate this in terms of fiscal responsibility for per city, that this this is going to lower costs. Criminal Justice costs, incarceration costs, the way they handle people at the jail here in Louisville, it's run into all sorts of problems and claims and if you look at what's happening in Norway and particularly the Netherlands, how the Netherlands Do you know anything about that about they in the Netherlands say their big problems, their jails are empty. So they started renting it out all these other countries, which I think is terrific. So what is it?

Now we conducted here with Urban and Public Affairs, and Dave Simpson other people. We did a some meeting on this building on compassionate city. And the people that Compassionate Louisville would not attend fought it said this was their domain and demanded that we not pursue it. We had presentations from the faculty here. We had all sorts of other groups come in talk about how we organizes stuff. We had representatives from the police department, and everything we hear and people really enthusiastic, and then they just said, we don't want to get into this. This is just gonna be a mess. And we said, yeah, we understand. And we had a whole thing about how Urban and Public Affairs did great that how you look at things and how you work with it and it went nowhere. And we could not get support from the city government on it.

Question 8

Answer:
Do you think by being a Compassionate City, Louisville gets attention from outside?

Oh, definitely. Oh, yeah. Yeah.

The League of Cities Association, talking about with a lot about how compassionate it is and everything.

And which I think is great. And I'd like to know, what do they mean when they say it's compassionate, how, and the murder rate and levels are really astounding. The amount of poverty in Louisville it's astounding in the West End. The environmental degradation over there where they dumped toxic waste next to the Ohio River has not been addressed mental health issues and so on, and the migration of people out to the east side of the city in enclaves, you know, it's got the same problems as a lot of other places.

So I think the sentiment is great. I have not seen any thing much than the Give a Day Program where there's any concrete coordination. And that's the role I think a city should have is helping in the coordination of this. Maybe there's something I just haven't seen it. And it's the same with Seattle. And it's I mean, Seattle's the first compassion city.

Have you heard the term skid road? It means that when all the bumps live It comes from Seattle. It's used all over the world. They used to skate the logs down the road to the words. Well, that's just the way and I went there. And the freeway, because Seattle, so hilly, the freeways dug inside a hill that comes up and is supported by pillars. And there are hundreds of tents 100 of the homeless, as people were driving by in their new Audi's and BMWs and Mercedes. And I said, this is a compassionate city? These people are getting out in the rain, and 
they're trying to get rid of them. They're an embarrassment, and so on. So if there is compassion to deal with, why has not this been dealt with? They certainly have the money to do that. What is happening, and I don't know what the other cities are doing. It appears to me to be window dressing largely no concrete thing.

It's the same with we've seen organizations that declare themselves to be compassionate and mostly, be nice to one another. Or you'll have like there's a technology company in North Carolina that hasn't declared that its compassionate. But I think it's one of the most compassionate organizations how they take care of Costco. The way they treat their employees. They took a lot of static from Wall Street, about you're paying them too much to give them health benefits. That's cutting into our thing. And the founder who have since retired, as the President said, Well, this is why we're successful as we treat people. Well, Costco is an example there's mill that had a fire in somewhere like New Hampshire, and the owner said, Well everybody staying on we are going to cut salaries, we're going to cut one, we're gonna cut mine because I make a lot of money on this. And I own the mill. And until we back up, everybody's on full salary. And that lasted for months. That's compassion and so It's hard because when your fighting business as usual, I show up to work today and what's the problem, we got to deal with others sorry. And to actually start have to stop and think and say we've got to invest in this, we've got to develop, we've got to develop this and we've got to mobilize people doesn't mean the city needs to actually expand a lot. what it needs to do is coordinate.

I think one of the things they're doing is they're looking at aging, because I'm the first year the baby boom 1946 and so baby boomers 1946 to 1964, huge population gain there is coming in, in the need assistance. Well, University of Louisville, is involved in some of that, and so they're doing a little bit of that. But again, there's no coordinated thing and mostly it's window dressings.

The Compassionate cities that are compassion are very often those who have been affirmed the Charter. They're just compassionate by their nature. And we see this in Scandinavia and, and some other places as certainly Glasgow. Scotland is an example of where they were. And I don't know if Glasgow Scotland is a compassionate city.

Question 9 Do you think there is a city which calls themselves compassionate without being affirmed by the Charter?

Answer: $\quad$ That is really a good question. I think there are. I don't know that. I think definitely there are. It seems to me there are cities that say that's a value that we have that we needed to exercise compassion towards. Yes. And we need to practice it. I don't know if Glasgow, Glasgow in Scotland had the highest crime rate murder rate in Europe, and they reversed it. By really researching it, again, the public health approach, getting people and responding to it. My understanding is they have said that compassion is a guiding principle for us. But whether they're a compassionate city, I don't know. It's easy to become a compassionate city from Charter of Compassion, you just need to affirm the Charter. So I don't know why somebody wouldn't, you know, but there may be some out there that are I don't know. I would love.

I have kind of left the idea working with organizations of the Compassionate City because in some respects, when it lost the requirement that you actually need do something to develop that was unique to your city. And that we coordinate that and there were two points that you do that, but then you exchange information with other cities about what you've done and how they can do it. And that never was put into place. Back then, there was pretty strong action against that saying that's just too hard. You're just going to alienate people. I lost interest in compassion city's campaign. I thought, well, we need to do more at the institutional level in schools and universities and hospitals and 


\section{Interview 2:}

Interview Code: 02

Interviewee Coder: 02

Date: February $5^{\text {th }} 2020$

Location: Department of Urban and Public Affairs, University of Louisville;

Louisville

\begin{tabular}{|c|c|}
\hline Question 1 & $\begin{array}{l}\text { Let's start with a little bit of history. How were you involved in } \\
\text { compassionate Louisville? }\end{array}$ \\
\hline Answer: & 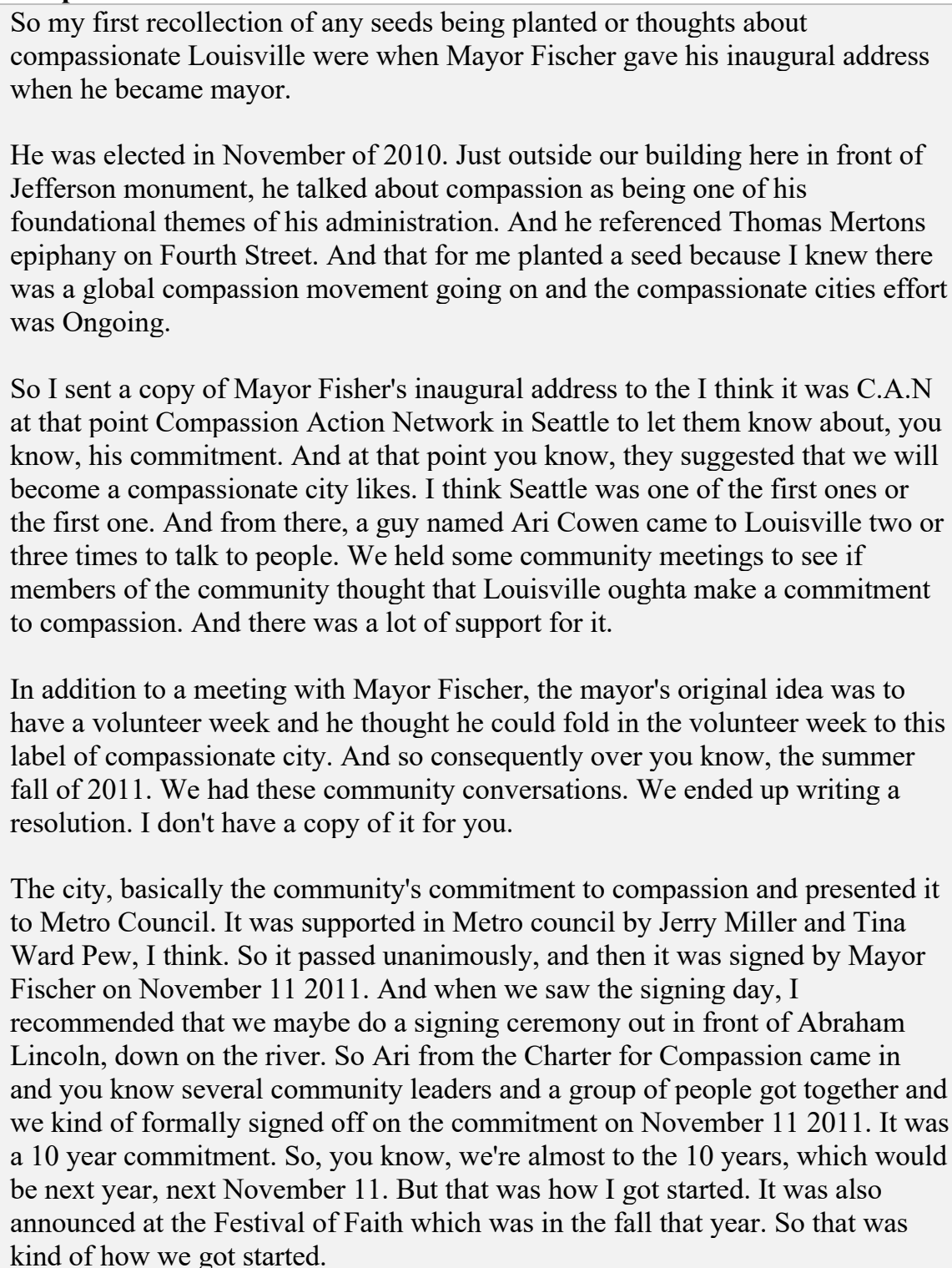 \\
\hline Question 2 & Why compassion? \\
\hline
\end{tabular}




\begin{tabular}{|c|c|}
\hline Answer & 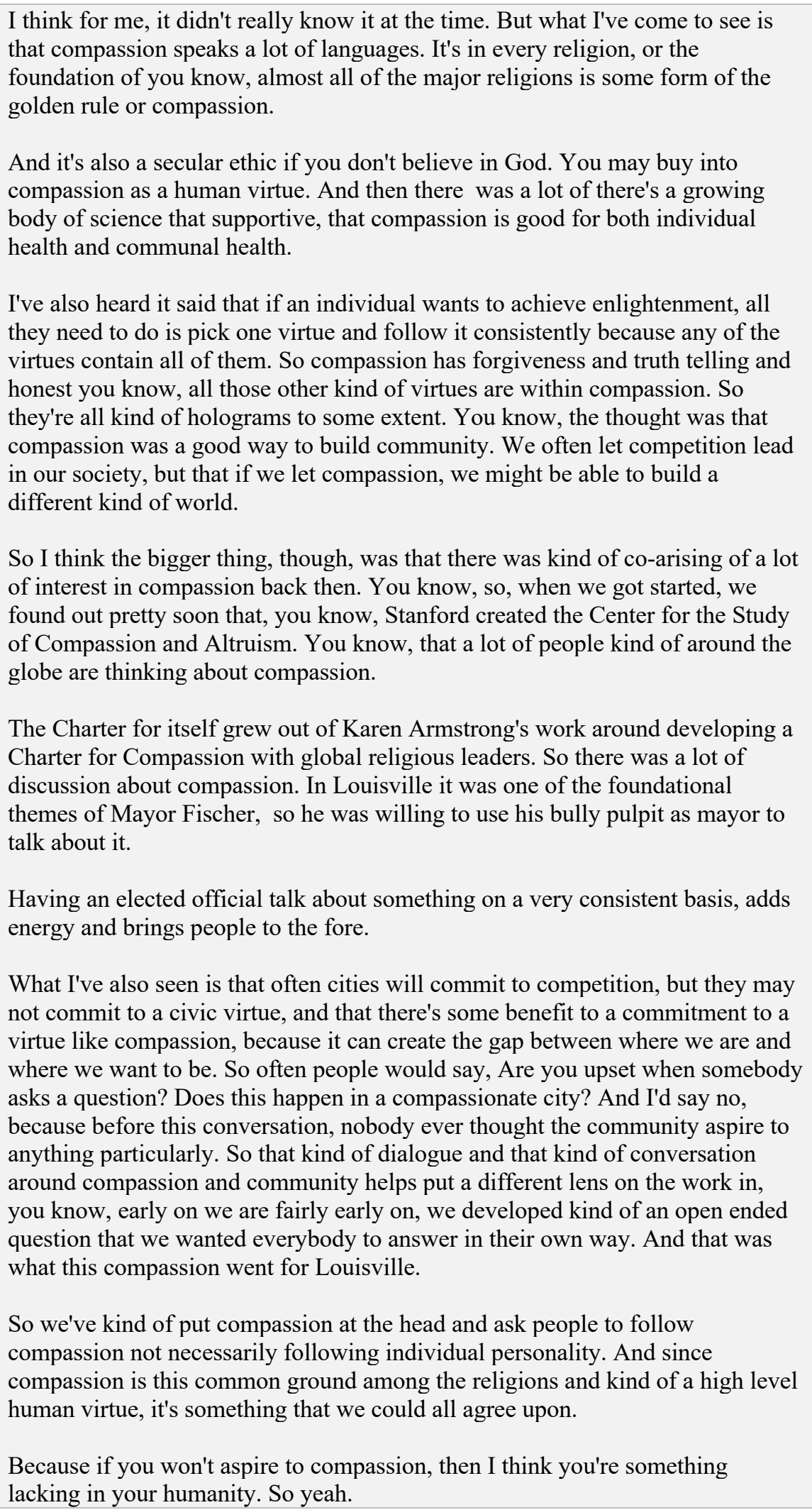 \\
\hline Question 3 & $\begin{array}{l}\text { Do you think compassion is a right? Or, what is the relationship between } \\
\text { compassion and rights? }\end{array}$ \\
\hline Answer & $\begin{array}{l}\text { Yeah, I think in this country, we are kind of very rights oriented, which means, } \\
\text { which is spoken in terms of individuality. I mean individuals hold rights, groups } \\
\text { don't hold rights. }\end{array}$ \\
\hline
\end{tabular}




\begin{tabular}{|c|c|}
\hline & $\begin{array}{l}\text { And I don't think compassion is so easily defined that you could call it as rights. } \\
\text { I think it's a different orientation. I think it's more an orientation around that } \\
\text { we're in our, you know, compassion talks about being interconnected, and in } \\
\text { community. And so you wouldn't like go to court and sue because you weren't } \\
\text { treated compassionately. So I would see it as kind of a different a different } \\
\text { framework than rights. }\end{array}$ \\
\hline Question 4 & How would you describe your role in making Louisville a compassionate city? \\
\hline Answer & $\begin{array}{l}\text { We use the language of host. So I was called a co host, along with Brenda Frank } \\
\text { and others. } \\
\text { And so, you know, my role was to help people ask the question, you know, } \\
\text { connect people into it, find out where people's energy was and try to connect that } \\
\text { energy with the bigger work around compassion in the community. } \\
\text { So, you know, I was a leader and more of a hosting sense, not a leader and } \\
\text { telling anybody what to do sense. I mean, because we didn't, we didn't tell } \\
\text { anybody what to do. We made suggestions. We suggested that individuals and } \\
\text { organizations make commitments like the city made a commitment to } \\
\text { compassion and we suggested to follow up on that commitment to compassion, } \\
\text { you find something that speaks to your heart, and then you do it. } \\
\text { And then if we all are doing this, then the theory was that compassion is good } \\
\text { soil to build community on that we would build a stronger community. Mayor } \\
\text { Fischer speaks in terms of social muscle, that compassion more creating } \\
\text { connections across difference in the community, build social muscle and avoids } \\
\text { things like what happened in Ferguson other communities that have kind of } \\
\text { erupted in violence. } \\
\text { So, I was unpaid, I was a volunteer and personally, I would try to treat } \\
\text { compassion, like I treat my clients. So I would try to, you know, and I try to } \\
\text { respond to my clients and I try to be open to what they want one, I try to help } \\
\text { them achieve their goals. And so that was my orientation towards compassion. } \\
\text { And it still is, to some extent it comes in different forms, but I try to serve } \\
\text { compassion because it's healing for me. } \\
\text { I think one of the things we said in the values, which is that compassion is a } \\
\text { bridge between internal practice and external change. So it's this thing that is } \\
\text { connecting me to the bigger thing helping me have a bigger dialogue with the } \\
\text { world. And so that's how I've viewed it is not a leader and kind of the } 1950 \text { sense } \\
\text { of not telling people what to do but a leader more in the sense of, I'm inviting } \\
\text { people to find what's meaningful inside of them and to in trying to help them } \\
\text { express that }\end{array}$ \\
\hline Question 5 & $\begin{array}{l}\text { From outside Louisville or people who are not from Louisville, how do you } \\
\text { think compassionate Louisville is seen? How does it help Louisville? }\end{array}$ \\
\hline Answer & $\begin{array}{l}\text { Mayor Fisher's office will say that they've gotten more calls from other cities } \\
\text { about the compassion effort than they have about anything else. Businesses have } \\
\text { relocated, at least anecdotally have told the mayor's office that part of why they } \\
\text { wanted to be in Louisville was the community's commitment to compassion. } \\
\text { We've hosted several outside groups from other cities organizers in to see what } \\
\text { we were doing and Louisville was named a model compassionate city by the } \\
\text { charter for compassion several times. And by my last count, you know, I talked } \\
\text { in some way to over } 40 \text { different communities, cities and towns, about } \\
\text { commitments to compassion and what that might look like. So The Dalai Lama } \\
\text { himself apparently talks about our commitment to compassion. And I heard him } \\
\text { say, in a meeting that we had Mayor Fischer and I and others had with the Dalai } \\
\text { Lama that Chinese CIP had a lot of revolutions around violence and what the } \\
\text { world needs is a compassion revolution, which makes sense for him because he's } \\
\text { viewed as the embodiment of compassion by Tibetan Buddhism. So I think the } \\
\text { Buddhists especially see compassion as a, you know, critical virtue. So I think }\end{array}$ \\
\hline
\end{tabular}




\begin{tabular}{|c|c|}
\hline & $\begin{array}{l}\text { from that from outsider standpoint, Louisville has been seen very positively with } \\
\text { this. If it's been noticed, I think some people, you know, it's not on our radar } \\
\text { screen so they wouldn't notice it. }\end{array}$ \\
\hline Question 6 & Can you name some of the companies that are interested? \\
\hline Answer & $\begin{array}{l}\text { Yeah, so, Spalding University made a commitment, early commitment to } \\
\text { compassion, and they've done a lot with it. } \\
\text { The University of Louisville medical school made a commitment and it's done a } \\
\text { lot with it. } \\
\text { UPS made a public commitment to compassion. } \\
\text { YUM! made a public commitment. } \\
\text { Computershares, a big company here in town, they were the ones that partly } \\
\text { relocated here because of the city's efforts around compassion. } \\
\text { Part of our organizing was to get businesses to make commitments. And we've } \\
\text { had over } 100 \text { organizations in town make commitments to compassion, you } \\
\text { know, big and small, so, and not really kept track of, I've got a there's probably a } \\
\text { list somewhere of them. } \\
\text { And we've not really monitored it. We've not set ourselves up as a watchdog to } \\
\text { kind of throw someone out if they've not lived up to our view of it. } \\
\text { The views been, if you make a commitment, you'll try to live consistently with } \\
\text { it. And if you don't live consistently with it, there be some anxiety which may } \\
\text { get motivate you to be consistent with it. } \\
\text { So those are some of the ones that come to mind there. Like I said, there were a } \\
\text { few others too. And some debates I mean, like, I think maybe Norton made a } \\
\text { commitment to compassion. And it was debated at their executive level, even } \\
\text { though was one of the values of their organization, should they make a public } \\
\text { commitment to it? Will that mean anything? You know, what's it mean for us? } \\
\text { So, um, you know, the hope was that if a group made a commitment, if they } \\
\text { weren't living consistently with it, they would be uncomfortable with that and try } \\
\text { to live consistently with it. }\end{array}$ \\
\hline Ques & So most of the \\
\hline Answer & $\begin{array}{l}\text { Yes, I think, well two parts to it. What we've described as the anchor project is } \\
\text { the mayor's volunteer week. And then the mayor has an assistant who's } \\
\text { responsible for compassion. Janice Cates is it now is Brenda Frank before, and } \\
\text { so she's, she's paid by the city, and she does more than just this compassion } \\
\text { work. But the Volunteer Week is a Volunteer Week. So Metro United Way's } \\
\text { support provides the platform and mayor's office helps plug people, individuals } \\
\text { and groups into projects for nonprofits. But, you know, the } 501 \text { C was developed } \\
\text { this past year for compassionate Louisville and again, it's at this point, it's still } \\
\text { all volunteer. No paid staff. }\end{array}$ \\
\hline Question 8 & $\begin{array}{l}\text { So, about the } 501 \mathrm{C} \text {, how do you feel compassion after like } 10 \text { years? How do } \\
\text { you think of the shape has Compassionate Louisville taken? }\end{array}$ \\
\hline Answer & $\begin{array}{l}\text { Right now it's reforming in some ways because there is still a grassroots group } \\
\text { working under kind of Compassionate Louisville logo. And then there's this } 501 \\
\text { that's created a new logo, that I'm not even necessarily in the loop on exactly } \\
\text { what they're doing at this point. I think they were going to focus on youth. } \\
\text { There is a desire by Mayor Fischer to make this part of his legacy. } \\
\text { So there's this conference of mayors initiative around inclusive and } \\
\text { compassionate city. So it's certainly not dead. It's not fully formed at this point. } \\
\text { You can't point to you know, one or two things that the compassionate rule itself } \\
\text { is doing because originally it was more of just an engagement process and a }\end{array}$ \\
\hline
\end{tabular}




\begin{tabular}{|c|c|}
\hline & $\begin{array}{l}\text { community lens, we described it almost like a Facebook page, you know, we } \\
\text { wanted to encourage people to plug in and do their thing. And now it's taking } \\
\text { more definitive shape. you'd have talked to Dr. Baber to see exactly what they're } \\
\text { what they're focused on currently.. }\end{array}$ \\
\hline Question 9 & So before it was more like grass roots. Now it's like an organization? \\
\hline Answer & $\begin{array}{l}\text { Yeah, it's an organization that still has grass roots, you know, working alongside } \\
\text { of it, I guess. Yeah. }\end{array}$ \\
\hline Question 11 & Why do you think there is a need for organization? \\
\hline Answer & $\begin{array}{l}\text { Raise money, you know, kind of the traditional things organizations do. I wasn't } \\
\text { part of creating an organization but I didn't necessarily object to it either. I mean, } \\
\text { I think it's, if you compare to a tree, I mean, you know, the roots ran and now it's } \\
\text { kind of broken through the ground and maybe it needs more structure in order to } \\
\text { survive in to have more impact in sustainability and scalability, I think, yeah. }\end{array}$ \\
\hline Question 12 & $\begin{array}{l}\text { We talked about how compassion is helping Louisville from outside. How's it } \\
\text { helping from inside what about the people of Louisville? How is compassion } \\
\text { helping people? }\end{array}$ \\
\hline Answer & $\begin{array}{l}\text { You know, and again, we don't have metrics necessarily to prove it. But } \\
\text { anecdotally, I think I can point to a lot of organizations that were inspired by the } \\
\text { compassion movement like we they kind of, they're separate, but they were kind } \\
\text { of inspired by compassion and love and I grew out of it and this group I'm part } \\
\text { of now Canopy which is around the socially conscious business movement } \\
\text { really grew out of a conversation around compassion and business. } \\
\text { You know, the Volunteer Week continues to grow and, you know, it's started at } \\
50,000 \text {. It's like } 200,000 \text { people now. It's become more a part of our daily } \\
\text { discussions. So I think it's created a community aspiration. } \\
\text { I think, you know, the Tibetan Buddhist center changed his name to the Drepung } \\
\text { Gomang Center for Engaging Compassion center for engaging compassion so } \\
\text { they've really focus part of their curriculum on compassion. } \\
\text { Earth and Spirit center is developed like a cultivating compassion curriculum. } \\
\text { The Islamic Center renamed itself to the Islamic Center for compassion. } \\
\text { So I think there's been an emphasis around compassion that, you know. } \\
\text { I know from personal experiences, helps bring well being and health. And so I'm } \\
\text { assuming it's been doing the same for others. Like Spalding in their commitment } \\
\text { to compassion they've grown out, work around restorative justice and } \\
\text { volunteerism. } \\
\text { And I think restorative justice is kind of a compassionate way to do justice } \\
\text { issues. It's grown into the Volunteers of America. So I think things related to or } \\
\text { connected with compassion are continuing to grow in the community. }\end{array}$ \\
\hline Question 13 & $\begin{array}{l}\text { Interesting that you say some of the organization are claiming themselves to be } \\
\text { Compassionate. However, most these are religious organizations: Buhddist, } \\
\text { Muslims. What is the reason of changing their name? Is that atraction? }\end{array}$ \\
\hline Answer & $\begin{array}{l}\text { Yeah, that that would be my assumption. The two of them change their name, } \\
\text { the one or spirit center stayed the same, but I think to fit into the bigger } \\
\text { movement, that would be my guess. } \\
\text { Dr. Baber was part of changing the name of the Islamic center and then the } \\
\text { Tibetan Buddhist center was around the Dalai Lama's visit. I mean, he raised } \\
\text { money for him to create a retreat center so and that is very kind of } \\
\text { fundamentally Buddhist is this emphasis on compassion. So I think that's why } \\
\text { they change the name. }\end{array}$ \\
\hline Question 14 & $\begin{array}{l}\text { What's the future vision? What do you hope to achieve with compassion in next } \\
5 \text { years? }\end{array}$ \\
\hline Answer & Well, I don't have a very, super clear vision on that. \\
\hline
\end{tabular}


I think the one thing that I've noticed is the conversation is deepening.

It started with kind of individual commitments, organizational commitments now, I think people are looking more closely at structures.

So, you know, this compassionate Cities Index that was developed at the University of Louisville, is still not been published.

And my hope would be that at some point, it could get published so the community could see the places in town that aren't kind of set up for human flourishing.

So I think that's my hope, things are pretty dark right now and the political narrative And landscapes and something new and different, maybe we'll grow out of the ashes.

And my hope is that kind of building communities around compassion could be what's next.

I don't know when but hopefully at some point, if we're to survive as a species, I think it's, you know, one of the talking points that we've used is, in my view, compassion is really true power.

You know, because if you look at, Hitler, you know, some of the people who we would, you know, maybe even use the term evil. What they stood for, had to be defended and would fall away and compassion is, in my view is kind of still and ineffable, and really the true source of power you look at, you know, in my tradition, somebody like Jesus, arguably wasn't even able to read and had a three year ministry and change the world.

Gandhi, you know, with non violence and, and compassion was able to make changes because you don't have to defend compassion people.

You know, like I said before, if you're not buying into compassion, then there's always something off about us human being so and that that wasn't my idea that was from this guy David Hawkins and his concept is that virtues have different energy levels and you know, love and compassion and some high energy level where anger and hatred is weak ultimately.

So it takes force to defend what's weak. What strong and love is really truly is powerful. Part of this has been not so much putting anything in or adding anything it's kind of removing obstacles to what's already in us because I think it's in all of us. I think it might be the energy that connects all of us, a name for it. There's a lot of names for it, but one of the names for it, I think, is compassion. And so we can remove the obstacles I think it I think it comes forward, I don't think we have to create it or build it. I think it's here.I might be, you know, alone and then view but that's my view. That's right.

Question 15 What constitutes a compassionate action? How would you define how would one define it?

Answer

It takes in my view, It takes some level of skill to be compassionate, and maybe experience.

So the example I give a lot is, if an alcoholic is screaming for a drink, and you give them a drink and they're quiet, you may think that you've done something compassionate, when really all you've done is enabled really poor behavior. Right? And so, it takes a level of discernment. 
It's hard to define. I mean, I think I think it's difficult to define it. Except maybe by examples, like the one I just gave, I mean, you know, at the time, it may have seemed like the compassionate thing to do, but then when you see that, giving the alcoholic drink leads to more drinking and his ultimate destruction and you know, hopefully change course and try to help them stop if that's a compassionate thing to do.

Some suffering is...I guess the Buddhists will say that life is suffering. I mean, you know, we're not going to alleviate all suffering. And I think the self compassion piece is part of it. I mean, I think compassion opens us up to see that we're really all part of the same tree. I mean, if I'm serving you, in some sense, I'm serving myself. And so I think I've been in this work, I've really tried to not get people off of defining because I think defining is very, you can create an argument that kind of misses the point, you know that that old adage of you know, religious leaders want to talk about the moon, but they end up kind of arguing about the finger pointing to the moon as opposed to, you know, looking at the moon.

I can't really answer your question real well. I think I know suffering when I meet it. sometimes I address it sometimes I don't. I mean, part of why I like compassion is a virtue to aspire to for myself and the community is that it ask something of us, I mean, I think I've talked to you about this before, but I'm Catholic and I've heard it said that it's easy for a priest to be against abortion because he can't get married and have kids. And so kind of grabbing the moral high ground on an issue that doesn't ask anything of you is pretty easy in some sense. And part of why like compassion as a virtue to aspire to is its a practice, I will never get it completely. And it ask something of me. You know, it asked me maybe to get out of myself. To move towards things that I think at its best, it gets you to move towards things that scare you. I mean, the things that are frightening, you know. Example, think of the St. Francis, I mean St. Francis in the Catholic tradition. He didn't really go on his mission until, you know, there's a story of him kissing the leper, but he had to kind of kiss the internal leper before he could kiss the external leper, I mean, and so, and he tamed the wolf and he had to tame the internal Wolf, before he could tame the external wolf.

So for me, compassion is very reciprocal kind of thing. I mean, the things that are showing up in my life that are asking compassion of me, is, how I grow, in my view is that God comes disguised as our life said, you know, all we have is the present. And if God's in every moment, then the things that are coming to me that are challenging me to act compassionately or how I become who I am, you know, at my best.

So again, I don't think I'm adding anything. To me I think it's, it's removing obstacles and revealing kind of what was already there is my viewpoint.

So I don't know if I've answered your question. I've talked around it, but bits of definitions are not. Through this work, if we had folks that were really caught up on definitions, I'd try to get them to find one that they're comfortable with and work with it. Yeah. And not, you know, like, for example, I wouldn't look at somebody and say, Well, if they're not suffering, then I'm not doing anything. I mean, it's hard to tell. It's challenging to tell who's some people suffer in silence some people you know, like, alcoholic example may be crying for something and you know, what's the right thing to do? It's not real simple. Sometimes.

Same with, you know, communities, like the nonprofit sector. I mean, sometimes I think the nonprofit sector is enabling, not necessarily enabling behavior, but maybe not really creating conditions for people to flourish the way they want to. 
There's a movie called poverty Inc. And the example they gave was like a church. And, you know, you could say a church in Kentucky gets inspired to help a small town in Africa. And so they send eggs for a year. over that year, they put all the egg farmers out of business in Africa, and then they get tired of it. And now, people don't have eggs and there's no egg farmers left and, you know, it seemed, maybe seems like a compassionate thing to do. But it maybe it was, I mean, maybe it was motivated by compassion, but if it wasn't skillful, you know, is it really helping to co create a better world. So it's a good question and I don't have many answers for it.

Question 16

How would you react to critiques of compassion? Like it can displace rights and justice, it makes someone high and other low?

\begin{tabular}{l|l} 
Answer & $\begin{array}{l}\text { We have said that compassion is not pity. } \\
\text { I don't see true compassion when I'm high and you're low. And I'm, you know, } \\
\text { giving because you're inadequate. }\end{array}$ \\
I think, for me, compassion includes some kind of exchange. \\
$\begin{array}{l}\text { And I think it also includes accountability. I mean, to me, it's not compassionate } \\
\text { to like the example I gave for the alcoholic. I mean, you know, you give them a } \\
\text { drink and they have a car wreck and you say well it's okay? Because you're an } \\
\text { alcoholic, you say, No, you're, you'd be accountable. }\end{array}$ \\
$\begin{array}{l}\text { So I've always included justice within the definition of compassion and I think } \\
\text { there are things you can cause wash, you can probably compassion wash, you } \\
\text { can kind of use it as a sword or misuse it as some way to take the moral high } \\
\text { ground on someone else. }\end{array}$
\end{tabular}

But to me, that's not really the energetic source that I'm feeling for compassion. I think it's something else. I think it's dishonest. If it's kind of dishonest and working from some kind of hidden agenda, I would call it something other than compassion. I think there's a spirit that unites us as humans, and that would be described as compassion or God.

And I think there's a spirit that divides, which is the opposite. And, you know, if it's coming from that spirit that's divisive, that wants to put me high and you low, then I wouldn't you know, maybe that's convenient for me. I wouldn't call it compassion. it's not like a machine that you can take the parts and label it and understand exactly how it works. this is not so subject to definition.

it's similar to God. I mean, the concept of God. I mean, a lot of people. You know, I'll talk to people and they say they don't believe in God. If you find out their concept of God, I'll probably say, Well, I don't believe in that God either.

I mean, you know, for me, God is much bigger. And, you know, from what you described, if people are calling that compassion, I would agree with them. And I don't see that as compassion. I mean, if it's trying to humiliate somebody or take pity on them or strip them of rights, in the name of compassion, then it's, it's not what it is and in my view, but you know, I think one of the criticisms has been that it's kind of a using the word compassion.

It's kind of the luxury of the privilege, then if you're in a survival mode if you're trying to pay your bills you don't have the luxury of just talking about compassion. Which I, I understand, in my view in Louisville for example, you know, East-End was wealthier than the West and East could go to the west and learn about compassion.

You know, the East End isn't going to go fix the West End, East End may have many things to offer the West material things to offer the West End but the West End probably has a lot of lessons and compassion to offer the East because East 
can hold up in little mansions and not talk to each other and, you know, people you don't have as many material resources have to connect with each other and be with each other, which to me is embodying compassion, communal compassion.

So I hear you and compassionate Louisville I've heard the critique is that it's about a volunteer week in bike lanes, and that's it, people would minimize it. And in my view that doesn't say anything about compassion, it says something about the person, you know, you can read the Bible. And based on your interpretation, I know more about you than I know about the Bible. I mean, there's things in our world that are mirrors for what's going on inside of us. And I think compassion is a similar thing. I mean, if people have not experienced compassion, they're very cynical about it. and it can actually be a big turn off. And I guess my argument would be, well, I don't think they really experience compassion. They experience something else and somebody may have called compassion but it probably wasn't it. Because I think religious leaders and all of the saints and mystics and all the traditions, you know who, who really know God, in my view have said that God is like, incredibly loving and compassionate. And so that's what God is. And if you're not experiencing it that way, then you're experiencing something else that somebody may be calling compassion, but it's not really. Yeah. But you know, not subject to easy definitions and in something that people struggle with themselves and practice themselves. 


\section{APPENDIX G - DOCUMENTS SHARED BY KEY INFORMANTS}

Scan Copy of the documents:

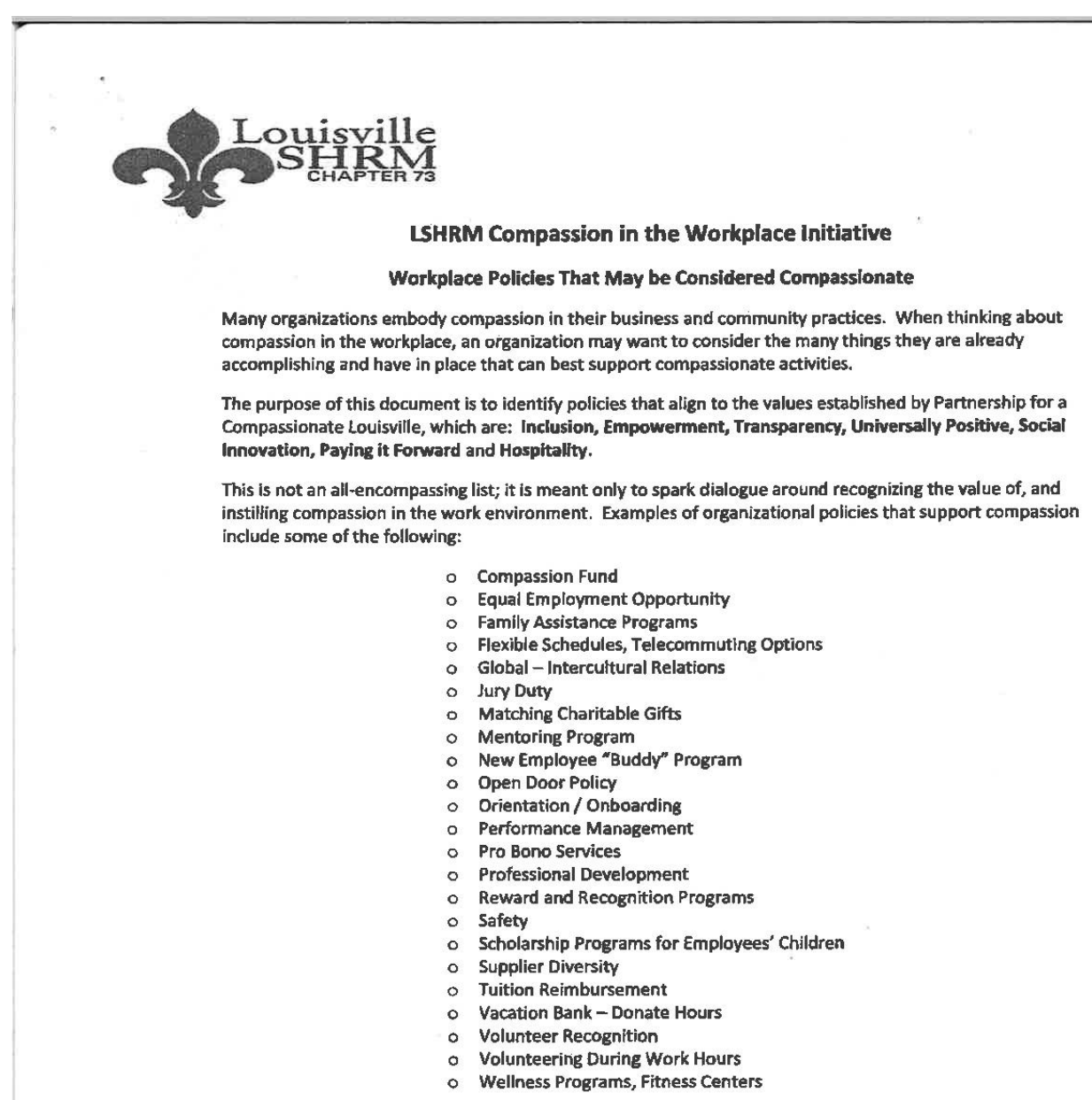

If you are interested in a particular policy, contact LSHRM at admin@lshrm.org and a member of the LSHRM compassion in the Workplace Project Team will respond to your request.

Another source for sample policies is SHRM -

http://www.shrm.org/TemplatesTools/Samples/Policies/Pages/default.aspx 


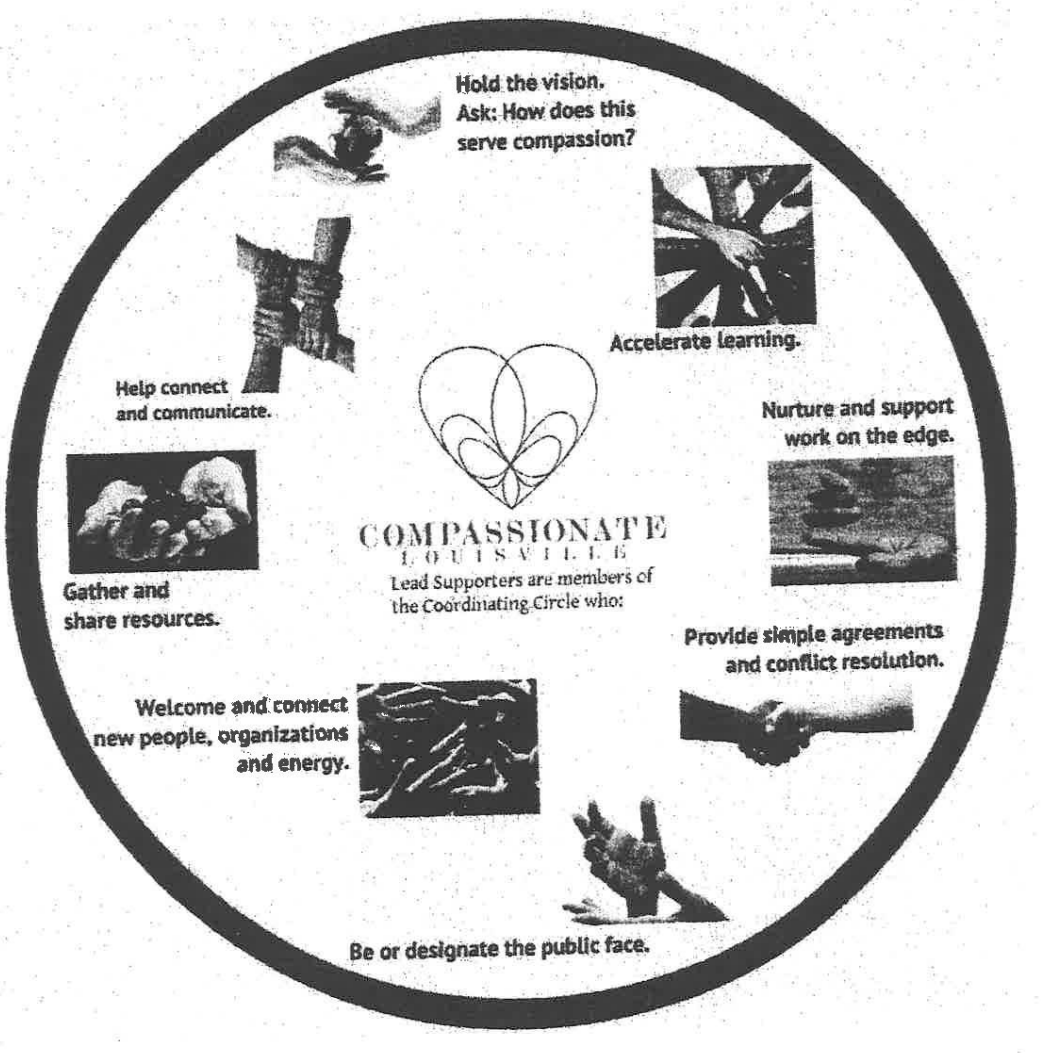




\section{Compassionate Louisville Traditions}

1. The only requirement for Compassionate Louisville membership is a desire to nurture and champion the growth of compassion.

2. Our common welfare is ever present; our work depends upon Compassionate Louisville unity.

3. Each constellation or group operates autonomously in its own domain while collaborating on matters affecting other groups or Compassionate Louisville as a whole.

4. We believe that compassion is a living system or organism that has its own evolutionary wisdom. Therefore we seek first to listen to that guiding wisdom. We are invited to listen and understand what compassion wants to become and what role each of us has in that evolution.

5. Because the wisdom of compassion is the true leader, guiding each from within and coordinating the whole, there is less need-and potentially no need-for hierarchy or consensus. The key capacity we must develop is the ability to listen deeply to this inner wisdom and act in alignment with that wisdom.

6. Leaders in our system of peer relationships are but trusted servants. Each of us is committed to the journey of individual and collective development into higher levels of capacity and self-awareness.

7. We work toward wholeness and we are invited to reclaim our inner wholeness and bring all of who we are to this work, including the emotional, intuitive, spiritual and rational parts of ourselves.

8. Compassionate Louisville only endorses the work of compassion. It is universally positive seeking to build a more just world through building and growing compassion.

9. Compassionate Louisville seeks to connect and inspire existing organizations to do the work of compassion and is willing and able to work with organizations large and small who commit to compassion.

10. Compassionate Louisville is not a watchdog organization and does not monitor the progress of any organization who commits to compassion.

11. Compassionate Louisville's name should never be related to any enterprise that does not reflect the vision, mission and values of the organization, including the value of being universally positive.

12. Compassionate Louisville seeks to build a better world for the next seven generations. We are ever reminded of those who came before us and those who come behind us. 


\section{5)Christianity}

For the Christian who has gone to their own depths, which is not all of them I am afraid, there is the uncovering of an Indwelling Presence, what might even be experienced as an IThou relationship, to use the language of the Jewish philosopher Martin Buber. In Christian theology this would be described as the "Holy Spirit", which is precisely God as immanent, within, and even our deepest self. Some saints and mystics have described this presence as "closer to me than I am to myself" or "more me than I am myself". Many of us would also describe this as the True Self. It must be awakened, it is never "created" by our actions or behavior, but naturally "indwelling", our inner being witb God.

Culture and even religion often teach us to live out of our false self of reputation, self image, roles, and possessions. It is only as this fails us, and it always eventually does, that the True Self normally stands revealed and ready to guide us. The True Self does not teach us compassion as much as it IS compassion already, and from this more spacious and grounded Self, one naturally connects, empathizes, forgives, and loves all reality. In

Chtistian language this is "God-in-me-loving-God", because the false self does not know

how to love In a very deep or broad way. It is too small and self referential to be compassionate. The True Self also does not choose to love as much as it IS love itselfalready. Loving from this spacious place is experienced as a tiver within you that flows of its own accord, as Jesus promises us so bcautifully (John 7:38).

-Richard Rohr

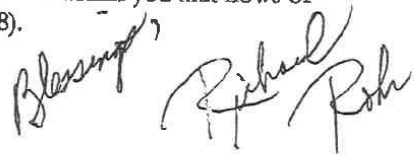




\section{Increasing Awareness of Our City's Compassionate Actions}

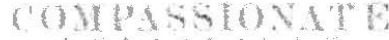

Compassionate Louisville celebrates, promotes and shares compassionate action through

- Facebook: https://www.facebook.com/Compassionate,Louisville

- Twitter: @compassionky

- Website: compassionatelouisville.or

- Compassionate Happenings weekly e-newslette

- Other awareness outreach

\begin{tabular}{|c|c|}
\hline $\begin{array}{l}\text { How Can Compassionate } \\
\text { Louisville Support Your } \\
\text { Compassionate Action? }\end{array}$ & $\begin{array}{l}\text { How Can You Support Compassionate } \\
\text { Louisville's Efforts to Celebrate, Promote, and } \\
\text { Share Compassionate Action? }\end{array}$ \\
\hline $\begin{array}{l}\text { - Post your events, news, photos, } \\
\text { and images on ComLou } \\
\text { Facebook page } \\
\text { - Tweet your events, news, } \\
\text { photos, and images on Twitter } \\
\text { feed @compassionky } \\
\text { - Create and maintain a section } \\
\text { on the Compassionate } \\
\text { Louisville website for your } \\
\text { Constellation } \\
\text { - Place your event on the } \\
\text { newsletter calendar } \\
\text { - Share articies, videos, news } \\
\text { items in the newsletter }\end{array}$ & $\begin{array}{l}\text { - Like the Compassionate Louisville Facebook page, } \\
\text { invite your friends to like the page } \\
\text { - Like and/or share the Facebook posts; if the posts are } \\
\text { not showing up on your news feed, Interact with } \\
\text { ComLou Facebook posts to increase visibility on your } \\
\text { Facebook page. (Like or share the posts) } \\
\text { - Follow @compassionky on Twitter } \\
\text { - Use @compassionky on any Tweet you send about } \\
\text { ComLou } \\
\text { - Ready your Compassionate Action on the website? } \\
\text { Talk to Vanessa Hurst } \\
\text { - Share information about your events 10-14 days } \\
\text { prior to the event with Vanessa } \\
\text { (hurst.vanessa@gmail.com) }\end{array}$ \\
\hline
\end{tabular}

Vanessa Hurst (hurst.vanessa@gmail.com) is available to support your awareness efforts. 


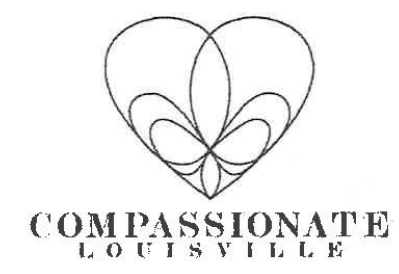

November 11, 2015

\title{
A Celebration of Compassion
}

\section{What Does Compassion Want For Louisville?}

\begin{abstract}
"Compassion is all-embracing. As indicated by the broad diversity of Constellations and affirming Compassionate Organizations, it does not recognize boundaries of any sort! Compassion wants to embrace seniors and students, the homeless and the wealthy, the sick and the healthy, the artists and the art-appreciators, those of faith and those in search, the unemployed and the job-makers, those needing a hand up and those needing to extend one, neighbors and neighborhoods. Our community has representation in all of these groups and more, and each is striving, even fighting in its own way, to let Compassion make its way, like water creating a stream bed, into the wealth of diversity that is Louisville. ${ }^{n}$
\end{abstract}

Wendy Sirchio

We Day, Kentucky 


\section{CHARTER FOR COMPASSION}

THE PRINCIPLE OF COMPASSION lies at the heart of all religious, ethical and spiritual traditions, calling us always to treat all others as we wish to be treated ourselves. Compassion impels us to work tirelessly to alleviate the suffering of our fellow creatures, to dethrone ourselves from the centre of our world and pu another there, and to honor the inviolable sanctity of every single human being, treating everybody, without exception, with absolute justice, equity and respect.

IT IS ALSO NECESSARY in both public and private life to refrain consistently and empathically from inflicting pain. To act or speak violently out of spite, chauvinism, or self-interest, to impoverish, exploit or deny basic rights to anybody, and to incite hatred by denigrating others-even our enemies-is a denial of our common humanity. We acknowledge that we have failed to live compassionately and that some have even increased the sum of human misery in the name of religion.

WE THEREFORE CALL UPON ALL MEN AND WOMEN to restore compassion to the centre of morality and L or disdain is illegitimate $\sim$ to ensure that youth are given accurate and respectful information about other traditions, religions and cultures $\sim$ to encourage a positive appreciation of cultural and religious diversity to cultivate an informed empathy with the suffering of all human beings-even those regarded as enemies.

WE URGENTLY NEED to make compassion a clear, luminous and dynamic force in our polarized world. Rooted in a principled determination to transcend selfishness, compassion can break down political, dogmatic, ideological and religious boundaries. Born of our deep interdependence, compassion is essential to human relationships and to a fulfilled humanity. It is the path to enlightenment, and indispensible to the creation of a just economy and a peaceful global community.

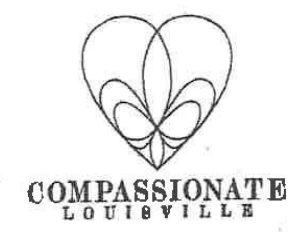




\section{Constellations of Compassion}

\section{ElderCounsel Constellation}

We are inclusive. All Louisville older adults are invited to participate. We gather on the fourth Wednesday of each month at 1:30 p.m. at Brescia Hall on the campus of Ursuline Community, 3105 Lexington Road. For more information, contact Terry McDevitt at terrymcdevitt@me.com or (445-1007).

\section{Education Constellation}

Our mission is to create a sustainable culture of compassion amongst ALL youth and education stakeholders in our community. To learn more or join, contact Jan Helson at ihelson@globaigamechangers.org.

\section{Trackers Constellation}

Our constellation activities are focused on tracking compassion year-round, but especially during the Compassion Games International (CGI) (www.compassiongames.org), and Mayor Fischer's annual Give-A-Day Week of Service (www.mygiveaday.com). Find and follow us on Facebook: (www.facebook.com/CompassionateLouisvilleTrackers) (www.facebook.com/CompassionateLouisville). Hosted by Lora Haynes, Ph.D., Associate Professor at the University of Louisville (Lora.Haynes@louisville.edu).

\section{Compassionate Conversations Constellation}

The Compassionate Conversations Constellation uses art to facilitate the discussion of tough topics that have an effect on our community. These conversations could help in the reduction of crime as they seek to bring all stakeholders to the table to discuss solutions, thereby giving everyone a sense of ownership. Tia Brown (tlbrown422@gmail.com), the host of the Compassionate Conversations Constellation, is also the founder of The Coming Woman LLC (www. The ComingWoman.org)

\section{Science Constellation}

The Science Constellation is a place for people interested in examining the construct of compassion and designing compassion research. The constellation hosts a dialogue that is open to academics and the community to discuss compassion constructs such as compassion, compassionate love, altruism, empathy, social connection, pro-social behaviors and other compassion related constructs of interest to members. Beginning January 2016, the Science Constellation will meet on the fourth Tuesday of the month from 8:30-9:30 a.m. at the Institute for Sustainable Health \& Optimal Aging, 300 East Market Street, Suite 300 . For information, contact Joe D'Ambrosio, Ph.D., at joe.dambrosio@louisville.edu. 


\section{Healthcare Constellation}

The Healthcare Constellation hosts any project, program or ide that allows compassion to be The Healthcare Constellation hosts any project, program dimensions of our work include: Care the driving force of our health-related experiences. The dimite and promote the work, Care for the for the Constellation and those "first followers" who grofessional satisfaction of those called to Caregivers, by improving the health, resilience and professional satisfaction of the for those healthcare service, and Care for Communilithealthconstellation@gmail.com.

heaking care. For more information, email louisvillehealthconstellation@amall.com.

\section{Earth Constellation} The intention of the Earth Constellation is to nurture an ecology of compassion for the Earth, as well as an ecology of compassion within the Earth care field. It is also our intent to celebrate the Earth care work that is already happening in our community. We hold thable, more satisfying compassion makes all of work more powerful, more effeclive, more sustain we are collaborating compassionturing. As a follow-up to an August Community Conversation, we are collaborating and more Hulthere Constellation on a soon-to-be announced chidren and nature focussion with the Healthcare Cons will include additional Community Conversations plus Compassion project. Future gatherings will in Joanna Macy's "Work that Reconnects." Mark Steiner is the

and Earth workshops rooted in Joanna

\section{Business Organizations Constellation}

A Compassion in Organizations was formed in 2013 and was active through 2014. After surwith constellation focused on supporting organizations with online resos also work in Louisville to connect with and learn from each other. During this period, there in Organizations." This proposal develop a study on the "Return on Investment of Compasson in that can be translated into is intended to re-focus the original intent of identifying metrics that can beovering "what's in "enlightened self-interests" for a partner organization; in other words, discovering "what clearly and for me" (WIIFM). The goal is to develop a strategic positioning process that clearles identified for me (1) benefits of compassion in the workplace and trablates idenes can specifically identicich by which the measurable outcomes can benefits into mow a compassionate investment of time, talent be shared with others, thus demonstrating how a compared in sharing their experiences, providing and treasure yields a return (ROI). Anyone interested in sharing theices "at work" is urged to feedback and/or receiving periodic updates on compassionate practices at (502) 558-2154. contact Brayton Bowen at brayton@howlandgroup.com or 


\section{COMMUNITY ART}

Why B.KIND?

B.KIND, a compassionate city project, produces mindful experiences of artistic, emotional, social, and physical intelligence, to give people food for their heart, brain, and body. In April of 2016, B.KIND plans to launch in Louisville, Kentucky on Waterfront Park's Big Four Bridge Lawn. B.KIND's mission is to work with creative forces to inspire citizens living in compassionate cities to feel more connected. BKIND has already started to invite creative forpa from Louisville, and the world, for this firstever launch of mindful experiench public. Invitations have been sent to innovators, performers, peace makers, light \& sound installation artists, musicians, professional meditators and yoga instructors, U.S. Olympic athletes to lead bicycle safety rides, city officials and curators to lead walks, local food trucks dispensing free food and water from the Big Four Bridge to the food deserts in the city of Louisville, and local chefs to create a dinner party that invites all of Louisville to connect. B.KIND contact for Louisville is Jesse Levesque (jesselevesque@gmail.com). Jesse Levesque is a curator, producer, and founder of The Ground Floor Gallery. Levesque brings twenty years of production experience to The Ground Floor. She has worked as a creative producer for professional theaters, big-budget commercials, film and television companies, and digital production companies in San Francisco, Los Angeles, Louisville, and Seattle.

\section{FREE RESOURCES}

Complimentary Leadership Team Coaching/Facilitation by Katie Gaughan

To support compassionate organizations in achieving their fulf potential, Compassionate Louisville Coordinating Circle member Katie Gaughan is offering 60-90 minute team coaching sessions at no cost to any organization that has signed a compassion resolution. Sessions will focus on a topic that is of particular importance to the organization and use a powerful Organization and Relationship Systems Coaching (ORSC) approach to support transformative dialog tapping into the compassion, creativity and collective wisdom of team members. For more information, contact Katie at katie@reachpointc.com or (502) 905-3813.

\section{A Compassionate Conversation}

Join in a lively discussion about how compassion can be the driving force to a happier, more joy filled life and how creating stronger connections with others naturally occurs when your intent to be compassionate manifests in your actions. Learn simple ways that raise your awareness of opportunities to share compassion. This facilitated conversation is available at no charge to organizations, churches, schools or other groups. Vanessa F. Hurst is a member of the Coordinating Circle for Compassionate Louisville and a Community Builder. She has a master's degree in Natural Health and regionally presents programs on contemplative living, compassion and intuition. As an intuitive healer and spiritual mentor, Vanessa understands that compassion, healing and growth are only possible through intent and action. To schedule a compassion conversation: (502) 599-7222 or hurst.vanessa@gmail.com. 


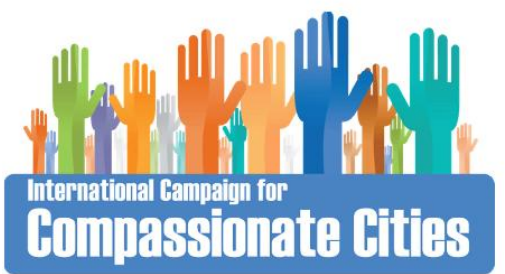

\section{DEVELOPING A COMPASSIONATE CITY CAMPAIGN}

Based on material provided by

Howard Mason ${ }^{1}$

New Possibilities Associates • Louisville, Kentucky USA

With additional information provided by the staff of the

International Institute for Compassionate Cities $^{2}$

\section{PLAN STEPS}

1. Assemble sponsor coalition - The groups and individuals who are seen as fair, neutral, and credible to be bringing this Campaign to the city and asking for widespread participation. This group could also serve as governance if that were to become necessary. Have each participant affirm the Charter for Compassion. ${ }^{3}$

2. Build a coalition of community groups - Build a coalition representing a broad range of community groups. These groups will join with the sponsor coalition to present the rationale and draft proclamation to the mayor and city council.

3. Open website and/or start a My Compassionate Action Network group where people join the local Campaign - Provide information on the Charter, the Compassionate Action Network ${ }^{4}$ and the International Campaign for Compassionate Cities; local conversations on living compassionately; guide on how to host a conversation; and a facility for people to record progress on the compassion work they are doing. Also establish Facebook page and Twitter accounts.

4. Recruit sector champions - These are people who evangelize for the Charter and the Campaign among their peers: business (sectors might be banking, finance, healthcare, manufacturing, logistics, etc.) government (local, state) faith communities, non-profits, civic groups, neighborhood associations, schools and educational institutions, and criminal-justice agencies.

5. Host several open, community-wide conversations - These conversations model and set the tone for the whole host of conversations that the Campaign would want to stimulate in families, workplaces, faith communities, schools, neighborhood gatherings, 
coffee shops, civic organization meetings, etc. These conversations would also be training for sector champions. Conversation questions:

What does living into the Charter for compassion look like in our organization, neighborhood or city?

What do we already have to support that picture of compassion?

What do we need to do or commit to doing to making our organization, neighborhood, or city compassionate?

6. Encourage many of these conversations in ordinary settings - Sponsors and secto champions promote and support conversations throughout community in in families, workplaces, faith communities, schools, neighborhood gatherings, coffee shops, civic organization meetings, etc.

Materials to host conversation would be available for download from the local website or group, and/or the International Institute for Compassionate Cities ("Institute") website. ${ }^{5}$ Conversation organizers would record participation, findings, insights, and plans on the website. Progress would be recorded as it occurs.

7. Make a presentation to the mayor and city council - Present a summary of the community support and the rationale behind the request for the mayor and city council to affirm the Charter for Compassion and proclaim support of a Compassionate Cities campaign. Submit a listing of endorsements, signatures gathered in support, and other compelling information if available.

8. Announce Compassionate City Initiative - Once the Charter is affirmed and the mayor and city council have approved the proclamation for a Compassionate City campaign, a public and publicized announcement (with the mayor presenting the proclamation) can be made emphasizing the Charter and the Campaign to seek endorsement of the Charter and participation in living into the Charter in our individual, family, work, faith, neighborhood and community lives.

9. Identify project candidates - Hold action-oriented conversation where participants are invited to bring their project, ideas, questions or whatever they feel called by and need help to launch or advance in the community. The conversation questions:

What project or idea has the power to transform the community and inspire you? What is the purpose of the project or idea?

What is missing? What is needed to make the project of idea more complete or possible?

What have we learned and what next steps are we ready to take?

10. Nurture a select group of compassion projects - Develop a process to screen and adopt a small number of projects for nurturing including mentors, opening doors, introductions, learning opportunities, etc.

11. Develop a plan - Create a plan for demonstration projects (that can be implemented later on a larger scale), identify outcomes, establish metrics, and tangible, measurable results to be reported back to everyone who participates in the Charter and the Campaign.

12. Innovate, expand, learn and share - These steps, with others, might be sufficient to get things rolling. But the Campaign must view itself as continuously innovating, taking 
advantage of unanticipated opportunities, inviting new people and ideas, capturing and sharing learning. Issue regular reports to the community.

\section{CHARACTERISTICS OF SUCCESSFUL COMMUNITY INITIATIVES}

\footnotetext{
The characteristics of successful community initiatives: ${ }^{6}$

1. Are based on clarity of shared purpose and principles.

2. Are self-organizing and self-governing in whole and in part.

3. Exist primarily to enable their constituent parts.

4. Are powered from the periphery, unified from the core.

5. Are durable in purpose and principle, malleable in form and function.

6. Equitably distribute power, rights, responsibility and rewards.

7. Harmoniously combine cooperation and competition.

8. Learn, adapt and innovate in ever expanding cycles.

9. Are compatible with the human spirit and the biosphere.

10. Liberate and amplify ingenuity, initiative and judgment.

11. Are compatible with and foster diversity, complexity and change.

12. Constructively utilize and harmonize ambiguity, conflict and paradox.

13. Restrain and appropriately embed command and control methods.
}

\section{DISCIPLINES OF THOSE LEADING COMPASSION BUILDING}

The goal of building compassion and transcending overt and covert violence is advanced by the capacity to generate, mobilize, and build four capacities in people. ${ }^{7}$

1. The centrality of relationships - Relationships form the context in which compassion happens and also generate the energy that enables people to transcend violence. As people acknowledge their relational interdependency and recognize themselves as part of the pattern, they may be able to envision a wider set of relationships and take personal responsibility for their own choices and behavior. In short, compassion requires that people be able to envision their interconnectedness and mutuality.

2. The practice of paradoxical curiosity - Cycles of violence are often driven by polarities. Choices about to respond to conflict are forced into either-or categories: you are either with us or against us. Compassion involves the capacity to rise above these divisions and reach beyond accepted meanings. Paradoxical curiosity is a matter of respecting complexity, seeking something beyond what is visible, and discovering what it is that holds apparently opposed social energies together. It involves accepting people at 
face value, and yet looking beyond appearances and suspending judgment in order to discover untold new angles, opportunities, and unexpected potentialities.

3. Provide space for the creative act - Compassion arises through creative human action that happens out of the everyday and yet moves beyond what exists to something new and unexpected. Because new ways of thinking may pose a threat to the status quo, it is important to provide space for the creative act to emerge. This requires a commitment to creativity and a belief that it is possible to move beyond the limits of what is commonly accepted. This quality of providing for and expecting the unexpected is well-known in the world of artists and needs to be cultivated in the wok of compassion building. Creativity opens us to avenues of inquiry and provides us with new ways to think about social change.

4. The willingness to risk - To take a risk is to step into the unknown without any guarantee of success or safety. For many people caught in conflict, violence is known, and compassion is a mystery. Because compassion building typically requires people to move toward a new, mysterious, and unexpected future, it may be a difficult journey.

\section{ADDITIONAL INFORMATION}

The International Institute for Compassion Cities provides a growing body of information and resources that can support local Compassionate City campaigns. These include information sheets, PowerPoint presentations, videos, and research information. Some materials can be customized to fit the local Campaign requirements, including contact information for the local Campaign. Please contact the Institute for more information.

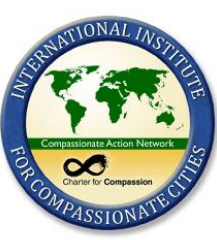

THE INTERNATIONAL INSTITUTE FOR COMPASSIONATE CITIES 13850 Bellevue Redmond Rd
Bellevue, WA 98005-4520 USA

+01 (425) 880-9450

contact@compassionatecities.org 


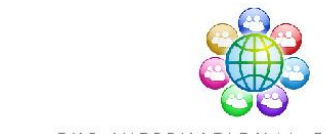

\section{Compassionate Organizations}

Louisville, Kentucky USA

On the web at: https://compassionate.center

Email:mail@compassionate.center

\section{THE CASE FOR \\ COMPASSIONATE ORGANIZATIONS}

WHITE PAPER

\section{Ari Cowan}

Wednesday, May 29, 2019

Abstract - The implementation of compassion values and practices is emerging as an approach to organizational development in a broad range of organizations worldwide. In this paper, the author explores the impact of compassion across all types of organizations (e.g., business, government, healthcare, education), why compassion is an essential competency, the consequences of failing to adopt compassion as a critical organizational operational component, and an example of the way in which organizations can progressively move their cultures into the compassion ethic. 


\section{Contents}

In the digital (PDF) version of this document, you can click on the entry below to directly link to the entry topic.

In Brief

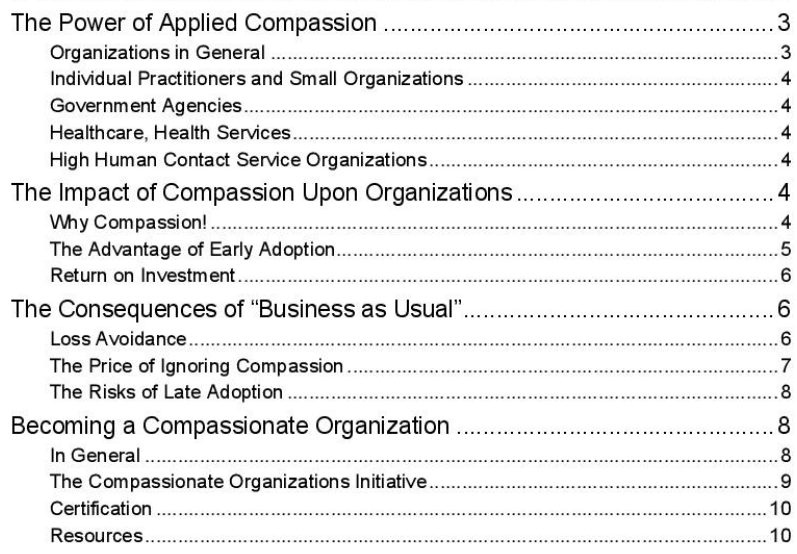

Some of the material included in this document is taken or derived from the independent writing including existing and forthcoming books and articles by Ari Cowan and/or Tony Belak. This material is reproduced here with permission.

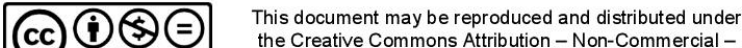
the Creative Commons Attribution - Non-Comm
No Derivatives 4.0 International License.

See: https://creativecommons. ora/licenses/by-nc-nd/4.0/ 


\section{In Brief}

"...it is for good reason the concept of organizational compassion, while still emerging, is touted as being the 'next big thing'."
Abusive "command and control" forms of management, the absence of a compassion competency within organizations, and the managerial cultures they create, risks devastating outcomes for corporations, educational institutions, healthcare systems, charitable institutions, governments, and other organizations. Abusive behaviors combined with indifference, or outright antagonism, toward employees, customers, vendors, shareholders, and others can result in devastating results for the offending organization.

Dr. Ben Farr-Wharton and Dr. Ace Simpson from the University of Technology Business School in Sydney, Australia, note that "when organizations allow employees to take time from their work to compassionately tend to, and care for, the suffering of colleagues, several positive individual and team-based outcomes ensue." 1 They explain that the concept may at first seem wasteful and indulgent, yet their research shows an emerging trend where organizations are "replacing fixed, bureaucratic processes with more agile, human-centric ones." Farr-Warton and Simpson note it "is for good reason the concept of organizational compassion, while still emerging, is touted as being the 'next big thing,."

\section{The Power of Applied Compassion}

"Compassion

is goodfor

the bottom

line, it's

great for

your

relationships,

and it

inspires

lasting

loyalty."
Stanford University's Emma Seppälä, $\mathrm{PhD}$ notes: “Compassion is good for the bottom line, it's great for your relationships, and it inspires lasting loyalty. In addition, compassion significantly boosts your health."2 Companies like Aetna, Gap, Starbucks, and Walmart are moving toward treating their employees better - incorporating many of the elements of a compassionate organization. ${ }^{3}$

Compassion values and practices will be meaningful for any organization, from sole practitioners and artisans, to large multinational conglomerates. The principles are essential to effective human interaction and support honest, ethical, and productive organizational settings.

In an 81-year study, Harvard University researchers found that the key to happiness and mental acuity is healthy relationships ${ }^{4}$ With so many people spending 200 hours or more at work each week, compassion - a basic requirement for healthy relationships - is essential.

\section{Organizations in General}

Companies that adopt compassion-based policies and practices can achieve a continuing cycle of increased employee loyalty and retention, customer 
satisfaction, and profitability. These organizations have a significant competitive advantage in recruiting new talent - especially when such talent is in short supply

\section{Individual Practitioners and Small Organizations}

Developing a compassionate organization competency is practical for individual practitioners and small organizations. Sole practitioners and small companies will benefit in terms of better relationships with customers, suppliers, partnering professionals and organizations, and the communities they serve. Embracing the value and practice of compassion can improve reputation, trust, and mutual success.

\section{Government Agencies}

For government agencies, the results can include increased staff satisfaction and effectiveness, greater agency creativity and responsiveness, and heightened citizen trust and participation. In areas that are prone to controversy and conflict (e.g., policing, corrections, urban development and renewal, environment), credibility and trust are increased - key elements that foster positive results

\section{Healthcare, Health Services}

In healthcare, the application of compassion produces better patient care and outcomes, shorter length of stay, lowered costs, reduced healthcare provider and staff burnout, and greater trust by patients and their families. ${ }^{5}$

Some of the benefits of compassion include leadership resilience increases, team dynamic improvements, and increases

organizational performance and retention.

\section{High Human Contact Service Organizations}

Service organizations that have continuing immediate and more intimate contact with consumers (e.g., airlines, hotels, restaurants, career coaches, counselors, transit coach operators, law firms) will find that a credible application of compassion-based policies and practices can increase their effectiveness and success.

The Impact of Compassion Upon Organizations

\section{Why Compassion!}

Uvinie Lubecki at Leading Through Connection identifies some of the benefits of building an organizational compassion competency: ${ }^{6}$

1. Leadership resilience increases. Building leader resilience can reduce incidents of depression, moodiness, and mental illness. Compassionate leaders tend to be calmer and increasingly effectively in dealing with emotional distress when dealing with suffering. Stephen Trzeciak, MD MPH and Anthony Mazzarelli, MD, JD, MBE, coauthors of Compassionomics: The Revolutionary Scientific Evidence that Caring 
Early adoption of $a$ compassion competency provides organizations with significant advantages.
Makes a Difference, came to similar conclusions about the effect of compassion upon healthcare providers. ${ }^{7}$

2. Team dynamic improve. Research demonstrates that the practica application of compassion produces higher levels of trust and mutually beneficial interaction between team members. Lubecki points out that a survey of 1,000 business leaders in more than 800 organizations who others saw as compassionate had teams who scored higher on critical performance dynamics within their organizations.

3. Organizational performance and retention increases. Collaboration across teams, commitment to the organization, and loyalty increased. Research on employee tenure and loyalty suggests that, when leaders perceived to incorporate high levels of compassion, their teams are $15 \%$ more like to stay with the organization. For example, a company with 50 employees achieving that $15 \%$ improvement would see an additional $\$ 400,000$ in added annual profit.

Referencing the work of Christina Boedker, ${ }^{8}$ Lubecki notes that when the compassion in incorporated as a leadership value and practice, it results in the following:

- Leaders spend more time and effort managing their people $(29.3 \%$ higher).

- Managers have clear values and practice what they preach $(25.7 \%$ higher).

- Senior people give employees opportunities to lead work assignments and activities ( $22.9 \%$ higher).

- Management encourages employee development and learning $(21.1 \%$ higher).

- Leaders welcome criticism and feedback as learning opportunities (20.4\% higher).

- Managers give increased recognition and acknowledgment to employee (19\% higher)

- Leaders foster involvement and co-operation amongst employees $(18 \%$ higher)

- Management communicates a clear vision and goals for the future (17.9\% higher)

- Managers are innovative and encourage staff to think about problems in new ways $(16.5 \%$ higher $)$

\section{The Advantage of Early Adoption}

Early adopters of compassion values and practices quickly define and develop their organization. The advantages they derive by adopting an organizational compassion initiative include:

1. The benefits mentioned earlier that result in greater effectiveness that, in turn, helps the organization achieve its goals (e.g., improved profits, 
enhanced service to citizens, better learning outcomes, injury and disease prevention).

2. High visibility resulting from the emerging recognition of appreciation from dispirited, burned out, and cynical views about business, government, education, healthcare, and other sectors by workers, citizens, students, patients and families, and others.

3. Differentiation from organizations that have not developed a compassion competency. For skeptical observers (e.g., customers, shareholders, employees), the contrast between organizations that embody compassion and those that do not is often vivid.

\section{Return on Investment}

The return on investment on establishing an organizational compassion competency falls into these general areas:

1. Cost savings through high productivity, reduced errors, greater creativity, more cooperation, less waste, reduced turnover, lowered absences, fewer health care costs (including the cost of sick days, medical leave of absence days, and illness on the job), fewer grievances, and customer and patient redress through lawsuits.

2. Improved responsiveness to opportunities and changes (including those in emerging markets, regulation, new practices and proficiencies) due to the safe, innovative, and success-oriented organizational ethic resulting from the development of compassion-based policies, practices, and skills

3. Positive public awareness and support arising from unmet public demand for more ethical, responsive, and human-centric organizational behavior.

\section{The Consequences of "Business as Usual"}

"Business as usual" can translate into significant problems for organizations.

\section{Loss Avoidance}

The absence of a professional, disciplined, and effective application of organizational compassion can lead to loss. Depending upon the type of organization, its objectives, and other factors, loss can take many forms included but not limited to

- Lowered productivity

- Reduced credibility

- Employee turnover increases

- Difficulty recruiting and retaining qualified staff

- Increased conflict and related claims

- More medical benefit costs
- Growing custome dissatisfaction

- Loss of credibility

- Increased lawsuits and fines

- Customer/client/patient dissatisfaction

- Deteriorating relationships with shareholders, vendors, and voters 
- High workers compensation claims

- Additional paid sick days

- Increased absenteeism
- Burdensome legislation

- Public contempt (refer to the examples below)

\section{The Price of Ignoring Compassion}

When some organizations ("early adopters") integrate compassion as a fundamental value and practice, they present a stark contrast to entities that are personified by the old command and control approach to management; mistreat customers, employees, and the public; engage in social prejudices (e.g., race, gender, age, religion. ethnicity) and demeaning behavior; or that go after profits at any cost.

The following three examples are illustrative of how the absence of compassion can lead to destructive effects across a range of organizational types.

\section{Papa John's Pizza}

Papa John's founder John Schnatter's comments about Col. Sander's racism, including a racial slur, proved disastrous for Schnatter and the pizza company. Schnatter's lack of awareness and sensitivity led to founder Schnatter's resignation for the company's Board of Directors and the University of Louisville's Board of Trustees, the University of Kentucky cutting ties to
Schnatter, and - ultimately — a dramatic drop in sales. ${ }^{9}$

The decision by Bank of

America to

charge $\$ 5$

debit-card

fees has

peeved

hordes of

customers,

prompting a

wave of

online

tirades and

a continued

flight to

local credit

unions.

Forbes reported that Papa John's culture was toxic. After Schnatter's criticism of the National Football League's handling of the national anthem protests, Papa John's shares dropped $11 \%$ in hours. Reports indicate Schnatter's behavior ranged from spying on his workers to sexually inappropriate conduct "which has resulted in at least two confidential settlements." Schnatter was not alone. There were allegations that he and other Papa John's executives engaged in "a laundry list of transgressions" - many directed at women. ${ }^{10}$

\section{Financial Industry Abuses}

Sued and fined, key institutions within the financial industry ${ }^{11}$ continue to work to establish credibility with government agencies and the public. They include prominent companies such as Bank of America, ${ }^{12.13}$ Wells Fargo, ${ }^{14,15}$ American Express, ${ }^{16}$ JPMorgan, ${ }^{17}$ Goldman Sachs, $,{ }^{18} \mathrm{HSBC},{ }^{19}$ Citigroup,${ }^{20}$ and Barclays..${ }^{21}$

The predatory and exploitive behavior of these and other institutions led to billions of dollars in fines, significant erosion in public trust, and increased government intervention. ${ }^{22.23}$ Additionally, their treatment of customers (particularly egregious in the case of Wells Fargo) and employee ${ }^{24}$ caused substantial suffering.

For example, after Bank of America decided to implement a $\$ 5$ monthly debi card fee in Washington State, many customers became fed up, previously experiencing a poor relationship with the bank. A day after the announcement, 
BECU - the largest credit union in the state — saw a surge in new members, breaking all previous records. ${ }^{25}$

\section{Pennsylvania State University}

The Los Angeles Times reported that former Penn State University President Graham B. Spanier was charged with conspiring with top university officials to cover up the actions of football coach Jerry Sandusky, convicted of abusing young boys. The university's response to the suffering of the victims was appalling. Pennsylvania Attorney General Linda Kelly noted that the university "turned a blind eye" to the serial predatory abuse. ${ }^{26}$

The scandal adversely impacted Penn State's reputation, athletic programs, and finances. In addition to legal costs, the Associated Press reported that "Penn State's trustees have authorized some $\$ 60$ million to be used for settlements." 27

\section{Other Examples}

Other examples appear in government, healthcare, hospitality, manufacturing, international trade, nonprofit, and most other types of organizations.

\section{The Risks of Late Adoption}

As compassion becomes more ingrained in organizations, late adopters of compassion policies and practices will face the twin challenges of losing customers, patients, votes, supporters, and investors while simultaneously needing to establish their compassion credentials. This dynamic is not new, “... in a survey of over 1,000 leaders from 800 cerer in the move to adopt other essential, ethical, and life-centric capabilities in the customer service, environmental, equal opportunity, human rights, and other worldwide movements.

Failure to adopt compassion competencies and practices in a timely way can produce especially devastating outcomes in some organizational segments such as government, healthcare, hospitality, and human services. Their harmful 91\% said compassion is very important for their leadership." traditional practices stand out in greater contrast when the presence of compassionate organizations is recognized.

\section{Becoming a Compassionate Organization}

\section{In General}

Leading Through Connection notes that, "in a survey of over 1,000 leaders from 800 organizations, $91 \%$ said compassion is very important for their leadership and $80 \%$ said they would like to enhance their compassion but do not know how. Many leaders believe that it's hard to balance results with compassion. Yet, in interviews, when compassion was accurately defined, almost all leaders said it reflected what it looked like when they were leading at their best." 28 
The skills needed to create organizational compassion competency include:

- Compassion (including empathy and emotional intelligence)

- Leadership

- Critical thinking

- Vision and motivation

- Power dynamics (Integrative Power Management Model)

- Conflict management (Integrative Conflict Management Model)

- Emotional intelligence

- Communication

- Relational

- Creating agreement

- Organizational citizenship

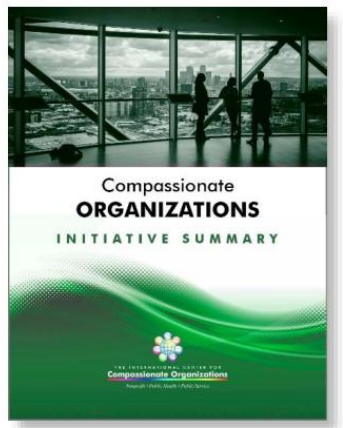

The Proposed Compassionate Organizations Initiative

The International Center for Compassionate Organizations plans to develop a Compassionate Organizations Initiative that is designed to build critical organization-related interpersonal skills to improve a broad range of positive success outcomes. The initiative consists of two tracks:

- Compassion-Trained Organizations (CTOs): organizations with a select group of employees who have completed any of the Compassionate Organization training programs.

- Accredited Compassionate Organizations (ACOs) organizations that have met the training, policy, and practice requirements for annual evaluation and accreditation as $\mathrm{CCOs}$

The proposed Organizations Initi will include an Initiative Summary that provides participation information and requirements.
Both programs will be evidence-based and designed for maximum effectiveness and minimum organizational demands in terms of financial, time, and other resource commitments. They incorporate a broad range of essentials including emotional intelligence, conflict management, early identification of relational problems (concerning employees, customers and clients, vendors, shareholders, social advocates, and others), preventive elements, and rapid response to emerging problem areas.

These innovative programs will draw upon extensive research. Online, ondemand multimedia training, support materials, and a rich body of online resources that are available $24 / 7$ will be included.

Practical application of these programs can produce significant reductions in costs, claims against the organization, employee tumover, etc. Establishing these programs can have a direct, positive impact on sales, productivity, organizational objectives, public trust, and more.

Using a public health approach, the initiative uses a 60-point assessment as a starting point for implementing a cost-effective and long-term approach to 
developing organizational compassion. The graphic on the following page illustrates the elements of this assessment.

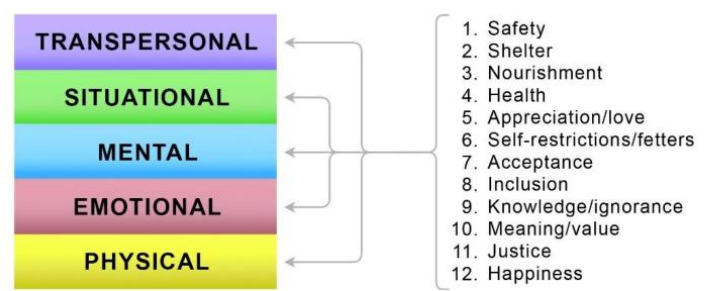

Certification

Certification of Compassion Trained Organizations (CTOs) will consist of an annual online compassion assessment, adoption of a compassion policy, and the implementation of a Compassionate Trust Leader Program.

Certification of Accredited Compassionate Organizations will incorporate the requirements for CTOs and adds adoption of compassion policies and practices, compassionate leadership training, and an annual accreditation review. There are qualification requirements including length of time of operation, meeting statutory requirements (human rights, health, environmental, etc.), ethical practices, absence of convictions or fines for illegal practices, and honest, ethical, and transparent operations.

Both programs will incorporate online, on-demand, and self-paced educational programs as well as online video conferences and a rich body of resources. More information about these programs is available upon request.

\section{Resources}

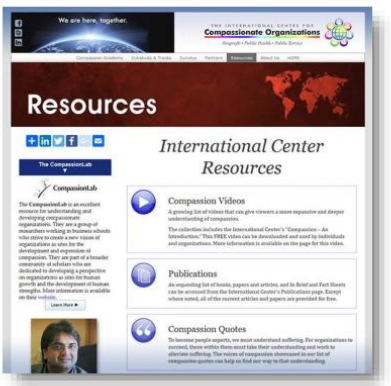

The Intemational Center provides many free resources including

- Videos, including "Compassion - An Introduction," the acclaimed short video that explains compassion and the need for it. Used worldwide, the video is available in English, French, and Greek.

- Publications, including a collection of White Papers and program descriptions. These are also free to download and use. A list of books that may be of interest to those wanting to know more about compassionate organizations is also included

- In Brief and Fact Sheets can also be downloaded and distributed. 
Note that, while many of these resources are provided at no charge, there are limits to their use. Please review the Creative Commons licenses for each resource before using them.

Notes

1 Farr-Wharton, Ben, and Ace Simpson. 2019. "Human-Centric Models of Management Are the Key to Ongoing Success." News - Australia. The Sydrey Morning Herald. May 23, 2019. hittps://www.smh.com.au/business/workplace/human-centric-models-of-management-are-the-key-toongoing-success-20190520-p51p82.html.

2 Seppälä, Emma. 2016. "Why Compassion Serves You Better Than Self-Interest." Academic Knowledge@Wharton. January 25, 2016. http://knowledge.wharton.upenn.edu/article'compassion-serves better-self-interestl.

3 Leber, Jessica. 2015. "Can Treating Low-Wage Workers Well Become The Hot New Business Strategy? News \& Comment. Fast Company. March 16, 2015. http://www.fastcoexist.com/3040830/worldchanging-ideas/can-treating-low-wage-workers-well-become-the-hot-new-business-strategy

Mautz, Scott. 2019. "An 81-Year Harvard Study Says Staying Happy and Mentally Sharp Boils Down to 1 Thing." Business. Inc.Com. May 28, 2019. https://www.inc.com/scott-mautz/an-81-year-harvard-studysays-stay ing-happy-mentally-sharp-boils-down-to-1-thing.html.

5 Trzeciak, Stephen. Compassionomics: The Revolutionary Scientific Evidence that Caring Makes a Difference (Kindle Locations 873-876). Studer Group. Kindle Edition. Stephen Trzeciak, MD, MPH and sis co-author, Anthony Mazzarelli, MD, JD, MBE, conducted a comprehensive review of the literature addressing the subject of compassion in healthcare settings.

Lubecki, Uvinie. n. . "Why Compassion?' Leadership. Leading Through Conmection. Accessed May 28, 2019. https://www.leadingthroughconnection. org/why-compassion

Trzeciak, Stephen. Compassionomics: The Revolutionary Scientific Evidence that Caring Makes a Difference (Kindle Locations 873-876). Studer Group. Kindle Edition.

Refer to a listing of Boedker's publications and research at the University of New South Wales a https://www.business. unsw.edu.au/our-people/christina-boedkertPublicationsResearch

9 Aulbach, Lucas. 2019. “A Timeline of the Papa John's Scandal, from the Slur to the Settlement." News \& Features. The Courier-Journal. March 5, 2019, https://www.courier-
joumal. com/story/money/companies/2019/03/05/papa-johns-scandal-timeline-john-schnatter-slurcontroversy-fallout 3065032002

10 Kirsch, Noah. nd. "The Inside Story Of Papa John's Toxic Culture." Forbes. Accessed May 3, 2019

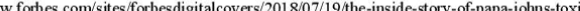
culture

11 Freifeld, Karen, and Steve Slater. 2015. "Major Banks Admit Guilt in Forex Probe, Fined \$6Billion." News. Reuters. May 20, 2015. http://www.reuters.com/article/2015/05/20/us-banks-forex-settlementidUSKBNOO50CQ20150520.

12 Raice, Shayndi, and Timiraos Nick. 2012، "U.S. Sues BofA for \$1 Billion Over Mortgage Losses."

10001424052970204530504578076680514724050.htmL.

13 Wagstaff, Keith. 2013. "Former Employees Say Bank of America Lied to a Lot of Homeowners." The Week. June 18, 2013. http://theweek. com/article/index/245782/former-employ ees-say-bank-of-americ 


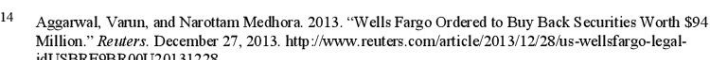

15 Jeffer, Don. 2012. "Wells Fargo, Schilling Sued by State Over 38 Studios." Bloomberg. November 1, 2012. http://www.bloomberg. com/news/2012-11-01/wells-fargo-schilling-sued-by-state-over-38-
studios html

Puzzanghera, Jim. 2012. "American Express to Refund \$85 Million to Credit Card Customers."

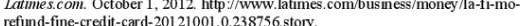

"TP Morgan to Pay \$1.7bn to Victims of the Madoff Fraud." 2014. BBC News. January 7, 2014.
http://www. bbc.co.uk/newsibusiness-25641476.

18 Pandey, Avaneesh. 2014. "Goldman Sachs To Shell Out \$3.15B In Settlement Over Mortgage Bonds."

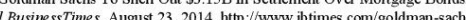
Business news. Intrmational BusinessTimes. August 23,2141
shell-out-315b-settlement-over-mortgage-bonds-1667140

19 "HSBC's Private Banking Arm Accused of Tax Fraud by Belgium." 2014. News. BBC News. November 17, 2014. http://www.bbc.com/news business-30078275.

20 Corkery, Michael. 2014. "Citigroup and U.S. Reach 57 Billion Mortgage Settlement." NYTimes.com. July 14, 2014. http://dealbook nytimes. com/2014/07/14/citigroup-and-u-1-reach-7- - billion-mortgagesettlement/.

"Barclays Fined \$435m in US over Energy Market-Rigging." 2013. July 16, 2013. BBC Neus. http://www. bbc.co.uk/news business-23337178.

22 "Iceland Jails Former Kaupthing Bank Bosses." 2013. BBC News. December 12, 2013. http://www.bbc.co. uk/news business-25349240 23 O'Toole, James. 2013 “"Switzerland's Oldest Bank Pleads Guilty to Aiding U.S. Tax Evasion." CNNcom.

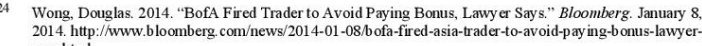
says.html.

25 Ho, Vanessa. 2011. "Debit Card Fees Irk Customers, Prompt Flight to Credit Unions." News Seattlepi.com. September 30, 2011. https://www.seattlepi.com/seattlenews/article-Debit-card-fees-irk-

26 Muskal, Michael. 2012. "Penn State Ex-President Charged in Sandusky Sex Abuse Cover-Up." Latimes.con. November 1, 2012. http://www:latimes. com/news/nation/nationnow/la-na-nn-former-penn-

7 Scolforo, Mark. nd. "Settlement Reached in Penn State-Sandusky Scandal." News. AP News. Accessed 28 Lubecki, Uvinie. n.d. "Why Compassion?' Leadership. Leading Through Commection. Accessed May 28 , 


\section{APPENDIX H - TRANSCRIPT OF LOUISVILLE METRO COUNCIL MEETING MINUTES}

from November 2011 to March 2020 that uses the word "compassion"

\begin{tabular}{|c|c|c|c|c|c|}
\hline Date & Document Name & Who & What & Context & Page \\
\hline $\begin{array}{l}11 / 12 / \\
14\end{array}$ & $\begin{array}{l}\text { Louisville Metro } \\
\text { Council Remote } \\
\text { Broadcast } \\
\text { Captioning, Dec } \\
11,2014\end{array}$ & $\begin{array}{l}\text { Paul Neuman, } \\
\text { CEO of a } \\
\text { company }\end{array}$ & $\begin{array}{l}\text { An increase over three years } \\
\text { in the minimum wage is } \\
\text { neither fair nor } \\
\text { compassionate. }\end{array}$ & $\begin{array}{l}\text { Discussing about } \\
\text { economic } \\
\text { argument of } \\
\text { minimum wage }\end{array}$ & 7 \\
\hline $5 / 1 / 16$ & $\begin{array}{l}\text { Louisville Metro } \\
\text { Council Remote } \\
\text { Broadcast } \\
\text { Captioning, Jan 5, } \\
2017\end{array}$ & $\begin{array}{l}\text { President } \\
\text { Yates }\end{array}$ & $\begin{array}{l}\text { It is our compassionate } \\
\text { responsibility }\end{array}$ & $\begin{array}{l}\text { During his } \\
\text { electorial speech, } \\
\text { he spoke about } \\
\text { the economic } \\
\text { development }\end{array}$ & 15 \\
\hline $\begin{array}{l}11 / 2 / 1 \\
6\end{array}$ & $\begin{array}{l}\text { Louisville Metro } \\
\text { Council Remote } \\
\text { Broadcast } \\
\text { Captioning, Feb 11, } \\
2016\end{array}$ & $\begin{array}{l}\text { Rev. Steven } \\
\text { Renner, pastor }\end{array}$ & $\begin{array}{l}\text { And there are thousands of } \\
\text { families like mine that will } \\
\text { benefit from this investment } \\
\text { in our compassionate } \\
\text { community. } \\
\text { That is almost } 25 \text { percent of } \\
\text { our compassionate } \\
\text { community's population. } \\
\text { In a compassionate } \\
\text { community, everyone } \\
\text { deserves a safe, } \\
\text { decent place to call home that } \\
\text { isn't leaking and flooding. }\end{array}$ & $\begin{array}{l}\text { Talking about } \\
\text { funding the } \\
\text { affordable } \\
\text { housing trust fund } \\
\text { through a small } \\
\text { increase in the } \\
\text { insurance } \\
\text { premium tax }\end{array}$ & 12,13 \\
\hline $\begin{array}{l}25 / 2 / 1 \\
6\end{array}$ & $\begin{array}{l}\text { Louisville Metro } \\
\text { Council Remote } \\
\text { Broadcast } \\
\text { Captioning, Feb 25, } \\
2016\end{array}$ & $\begin{array}{l}\text { Green, } \\
\text { Councilwoma } \\
\mathrm{n}\end{array}$ & $\begin{array}{l}\text { Giving because you don't } \\
\text { have to give for no other } \\
\text { reason than just because is } \\
\text { something that we as a } \\
\text { compassionate city and as } \\
\text { Louisvillians should do. }\end{array}$ & $\begin{array}{l}\text { Talked about } \\
\text { different people } \\
\text { suffering from } \\
\text { illness }\end{array}$ & 6 \\
\hline $\begin{array}{l}15 / 12 / \\
16\end{array}$ & $\begin{array}{l}\text { Louisville Metro } \\
\text { Council Remote } \\
\text { Broadcast } \\
\text { Captioning, Dec } \\
15,2016 \\
\end{array}$ & $\begin{array}{l}\text { Kramer, } \\
\text { Councilman }\end{array}$ & $\begin{array}{l}\text { What those of us who came to } \\
\text { know Kelly learned quickly } \\
\text { was the depth of his } \\
\text { compassion. }\end{array}$ & $\begin{array}{l}\text { Recognizing } \\
\text { Kelly Downard as } \\
\text { a leader }\end{array}$ & 68 \\
\hline $\begin{array}{l}8 / 12 / 1 \\
6\end{array}$ & $\begin{array}{l}\text { Louisville Metro } \\
\text { Council Remote } \\
\text { Broadcast } \\
\text { Captioning, Dec 8, } \\
2016\end{array}$ & $\begin{array}{l}\text { Vicki Aubrey } \\
\text { Welch, } \\
\text { council } \\
\text { woman }\end{array}$ & $\begin{array}{l}\text { Monica is one of the most } \\
\text { compassionate, loving, and } \\
\text { faithful people that I have } \\
\text { ever known. }\end{array}$ & $\begin{array}{l}\text { Talking about } \\
\text { Monica, who } \\
\text { pastored at Cole } \\
\text { Baptist church }\end{array}$ & 16 \\
\hline
\end{tabular}




\begin{tabular}{|c|c|c|c|c|c|}
\hline \multirow[t]{2}{*}{$\begin{array}{l}23 / 3 / 1 \\
6\end{array}$} & \multirow[t]{2}{*}{$\begin{array}{l}\text { Louisville Metro } \\
\text { Council Remote } \\
\text { Broadcast } \\
\text { Captioning, Mar } \\
\text { 23, } 2017\end{array}$} & $\begin{array}{l}\text { Yazmin } \\
\text { Martinez, } \\
\text { Council } \\
\text { member }\end{array}$ & $\begin{array}{l}\text { 1.I have seen Louisville grow } \\
\text { and become more } \\
\text { compassionate, and inclusive } \\
\text { to immigrants and LGBTQ. } \\
\text { 2. Louisville as a } \\
\text { compassionate city could be } \\
\text { making impactful changes in } \\
\text { the immigrant community by } \\
\text { using money they use to fund } \\
\text { ICE or other agencies. } \\
\text { 3. Compassionate is } \\
\text { sanctuary. }\end{array}$ & $\begin{array}{l}\text { Was describing } \\
\text { his experience as } \\
\text { an immigrant in } \\
\text { Louisville }\end{array}$ & 4 \\
\hline & & $\begin{array}{l}\text { Erika } \\
\text { Williams, } \\
\text { member of } \\
\text { KFCC }\end{array}$ & $\begin{array}{l}\text { In the face of fear, we can be } \\
\text { compassionate. A } \\
\text { compassionate } \\
\text { city knows kindness in the } \\
\text { face of hate. A compassionate } \\
\text { city provides } \\
\text { protection for its members, } \\
\text { protections that extend } \\
\text { beyond } \\
\text { simply -- -- that builds } \\
\text { communities and prosper. A } \\
\text { city cannot be } \\
\text { compassionate in name only } \\
\text { because showing compassion } \\
\text { is not passion. Showing } \\
\text { compassion requires } \\
\text { enormous emotional strength, } \\
\text { empathy, and the desire to } \\
\text { face what is so obviously } \\
\text { wrong. Right now the city } \\
\text { needs your leadership. I urge } \\
\text { you to listen to your } \\
\text { community and adopt policies } \\
\text { to make Louisville a } \\
\text { compassionate city. }\end{array}$ & $\begin{array}{l}\text { Talked about the } \\
\text { growing coalition } \\
\text { and violence and } \\
\text { budget should be } \\
\text { spend on } \\
\text { actionable } \\
\text { policies }\end{array}$ & $7-8$ \\
\hline $\begin{array}{l}13 / 4 / 1 \\
7\end{array}$ & $\begin{array}{l}\text { Louisville Metro } \\
\text { Council Remote } \\
\text { Broadcast } \\
\text { Captioning, Apr 13, } \\
2017\end{array}$ & $\begin{array}{l}\text { Debra } \\
\text { Mumford, } \\
\text { council } \\
\text { member }\end{array}$ & $\begin{array}{l}\text { On november 11th, } 2011 \\
\text { louisville metro council } \\
\text { unanimously voted to adopt } \\
\text { the charter for compassion, a } \\
\text { 10-year campaign for } \\
\text { compassionate cities, } \\
\text { establish april as } \\
\text { compassionate action month } \\
\text { and decided louisville, } \\
\text { kentucky is the compassionate } \\
\text { heart of america. At festivals } \\
\text { and speeches around the city } \\
\text { and nation, mayor greg fisher } \\
\text { defines compassion for } \\
\text { respect for each and every } \\
\text { person so their human } \\
\text { potential is flourishing, } \\
\text { thriving, or shining like the } \\
\text { sun. } \\
\text { 2.compassionate cities where } \\
\text { they refuse to cooperate with } \\
\text { unjust laws for detainment } \\
\text { and deportation of people. } \\
\text { 3. Sanctuary cities are } \\
\text { compassionate cities that } \\
\text { advocate for the health and } \\
\text { well-being of all people. } \\
\text { 4.sanctuary cities are } \\
\text { compassionate cities, } \\
\text { therefore it only makes sense }\end{array}$ & $\begin{array}{l}\text { While talking } \\
\text { about the } 10 \text { year } \\
\text { campaign for the } \\
\text { compassionate } \\
\text { city }\end{array}$ & $5,6,7$ \\
\hline
\end{tabular}




\begin{tabular}{|c|c|c|c|c|c|}
\hline & & & $\begin{array}{l}\text { that our city which has } \\
\text { declared itself to be the } \\
\text { compassionate heart of } \\
\text { america, should also commit } \\
\text { to becoming a sanctuary city }\end{array}$ & & \\
\hline & & $\begin{array}{l}\text { Donna } \\
\text { Pollard, } \\
\text { President- } \\
\text { elect of UN } \\
\text { Association, } \\
\text { Kentucky and } \\
\text { member of } \\
\text { state attorney } \\
\text { general } \\
\text { council }\end{array}$ & $\begin{array}{l}\text { I firmly believe in order to } \\
\text { fully address and eliminate } \\
\text { this horrific offense, we must } \\
\text { continue to raise community } \\
\text { awareness of the issue, as } \\
\text { well as compassion for all } \\
\text { victims. }\end{array}$ & $\begin{array}{l}\text { Inviting everyone } \\
\text { of the screening } \\
\text { of the document " } \\
\text { I am ane Doe" } \\
\text { which deal with } \\
\text { the epidemic of } \\
\text { child sex } \\
\text { trafficking in } \\
\text { USA }\end{array}$ & 7 \\
\hline $\begin{array}{l}27 / 4 / 1 \\
7\end{array}$ & $\begin{array}{l}\text { Louisville Metro } \\
\text { Council Remote } \\
\text { Broadcast } \\
\text { Captioning, April } \\
27,2017\end{array}$ & $\begin{array}{l}\text { Mayor Greg } \\
\text { Fischer }\end{array}$ & $\begin{array}{l}\text { And when I was sworn in, I } \\
\text { pledged three core values } \\
\text { would guide my } \\
\text { administration, a city of } \\
\text { lifelong learning, a healthier } \\
\text { city and an even more } \\
\text { compassionate city. } \\
\text { We have become an } \\
\text { international leader in } \\
\text { compassion through programs } \\
\text { like give a day, which this } \\
\text { year tallied a record } 180,000 \\
\text { volunteers in acts of } \\
\text { compassion. The council has } \\
\text { been a significant partner in } \\
\text { this mission, unanimously } \\
\text { passing in } 2011 \text { a resolution } \\
\text { making us the first large } \\
\text { American city to sign the } \\
\text { charter for compassion. And } \\
\text { compassion has helped us in } \\
\text { many ways. It builds our } \\
\text { social muscles as part of our } \\
\text { global brand, and as you have } \\
\text { heard me say, computer share } \\
\text { chose Louisville in part } \\
\text { because of our city's emphasis } \\
\text { on compassion. So } \\
\text { compassion is good for } \\
\text { business. And while it doesn't } \\
\text { have a line item in the budget, } \\
\text { compassion informs the } \\
\text { decisions behind each of the } \\
\text { investments we make for our } \\
\text { citizens. } \\
\text { And we are going to continue } \\
\text { our emphasis on compassion. } \\
\text { I'm tremendously proud of the } \\
\text { work we have done to } \\
\text { cultivate compassion in our } \\
\text { city. And I look forward to } \\
\text { the work ahead. Because } \\
\text { when I look around the } \\
\text { community and our country, I } \\
\text { see the need for more } \\
\text { compassion, not less. }\end{array}$ & $\begin{array}{l}\text { While delivering } \\
\text { his speech during } \\
\text { his proposed } \\
\text { budget for FY } \\
2017-18\end{array}$ & $5,7.23$ \\
\hline
\end{tabular}




\begin{tabular}{|c|c|c|c|c|c|}
\hline \multirow[t]{2}{*}{$\begin{array}{l}11 / 5 / 1 \\
7\end{array}$} & \multirow[t]{2}{*}{$\begin{array}{l}\text { Louisville Metro } \\
\text { Council Remote } \\
\text { Broadcast } \\
\text { Captioning, May } \\
\text { 11, } 2017\end{array}$} & $\begin{array}{l}\text { Dzemlia } \\
\text { Bilanozic, } \\
\text { representative, } \\
\text { immigrant }\end{array}$ & $\begin{array}{l}\text { On the first day of the festival } \\
\text { in one of the first sessions } \\
\text { talking about getting real } \\
\text { about compassionate } \\
\text { cities,mayors including our } \\
\text { own spoke about what it } \\
\text { means to be a compassionate } \\
\text { city. To kick off the session } \\
\text { author Karen Armstrong, } \\
\text { compassion is not just a nice } \\
\text { idea.She went on to say } \\
\text { compassionate cities disturb } \\
\text { our dreams. What she meant } \\
\text { was the act of being } \\
\text { compassionate towards } \\
\text { another person should make } \\
\text { us uncomfortable because it is } \\
\text { not easy. So I ask what is a } \\
\text { compassionate city that does } \\
\text { not provide that city to all } \\
\text { who live, work, and play in it, } \\
\text { if it does not stand up to } \\
\text { bigotry and hatred by } \\
\text { standing for and with its } \\
\text { Muslim brothers and sisters, } \\
\text { its black brothers and sisters, } \\
\text { undocumented and unafraid, } \\
\text { disabled, and LGBTQ. How } \\
\text { can we call ourselves a } \\
\text { compassionate city? }\end{array}$ & $\begin{array}{l}\text { While speaking } \\
\text { about her her } \\
\text { support } \\
\text { for Louisville } \\
\text { becoming a } \\
\text { sanctuary city. }\end{array}$ & 6,7 \\
\hline & & $\begin{array}{l}\text { Jackie } \\
\text { Belcher, } \\
\text { student } \\
\text { UOFL, } \\
\text { Louisvillian }\end{array}$ & $\begin{array}{l}\text { Recently we have been going } \\
\text { by opportunity city and } \\
\text { compassionate city. Now we } \\
\text { claim to be a welcoming city. }\end{array}$ & $\begin{array}{l}\text { Talking about US } \\
\text { Customs and } \\
\text { Border control for } \\
\text { immigrants }\end{array}$ & 14 \\
\hline $\begin{array}{l}30 / 11 / \\
17\end{array}$ & $\begin{array}{l}\text { Louisville Metro } \\
\text { Council Remote } \\
\text { Broadcast } \\
\text { Captioning, Nov } \\
30,2017\end{array}$ & $\begin{array}{l}\text { Leet, council } \\
\text { member }\end{array}$ & $\begin{array}{l}\text { Just to have awareness and } \\
\text { compassion and } \\
\text { understanding for this. }\end{array}$ & $\begin{array}{l}\text { Talking about } \\
\text { raising awareness } \\
\text { of epilepsy }\end{array}$ & 21 \\
\hline \multirow[t]{2}{*}{$\begin{array}{l}13 / 7 / 1 \\
7\end{array}$} & \multirow[t]{2}{*}{$\begin{array}{l}\text { Louisville Metro } \\
\text { Council Remote } \\
\text { Broadcast } \\
\text { Captioning, July } \\
\text { 13, } 2017\end{array}$} & $\begin{array}{l}\text { Dave Cooper, } \\
\text { Council } \\
\text { member }\end{array}$ & $\begin{array}{l}\text { We often refer to louisville as } \\
\text { a compassionate city, and I } \\
\text { ask you what does that mean? } \\
\text { I would like to close by } \\
\text { saying that these are our } \\
\text { brothers and sisters, our } \\
\text { parents, husbands, and wives, } \\
\text { and they deserve our } \\
\text { compassion. }\end{array}$ & $\begin{array}{l}\text { In his speech of } \\
\text { deportation, } \\
\text { requesting to } \\
\text { designate } \\
\text { Louisville as a } \\
\text { sanctuary city for } \\
\text { refugees in order } \\
\text { to reduce crime }\end{array}$ & 7,8 \\
\hline & & $\begin{array}{l}\text { Clara } \\
\text { Ruplinger, } \\
\text { council } \\
\text { member }\end{array}$ & $\begin{array}{l}\text { There are people who are } \\
\text { ready to back you up should } \\
\text { you take a stand against these } \\
\text { unjustified and fear-filled } \\
\text { attacks, but we can only do } \\
\text { this if you have the courage to } \\
\text { stand for what is right and } \\
\text { show that louisville is a truly } \\
\text { compassionate city. }\end{array}$ & $\begin{array}{l}\text { In her speech of } \\
\text { racial justice and } \\
\text { to support making } \\
\text { Louisville as a } \\
\text { sanctuary city }\end{array}$ & 10 \\
\hline $\begin{array}{l}26 / 10 / \\
17\end{array}$ & $\begin{array}{l}\text { Louisville Metro } \\
\text { Council Remote } \\
\text { Broadcast } \\
\text { Captioning, Oct 26, } \\
2017\end{array}$ & $\begin{array}{l}\text { President } \\
\text { Yates }\end{array}$ & $\begin{array}{l}\text { Caring and compassionate } \\
\text { field entry, outside school he } \\
\text { has played soccer at mocking } \\
\text { bird valley. }\end{array}$ & $\begin{array}{l}\text { In his speech } \\
\text { while describing } \\
\text { council member } \\
\text { Dominic Keder }\end{array}$ & 3 \\
\hline
\end{tabular}




\begin{tabular}{|c|c|c|c|c|c|}
\hline & & Dr. Bannerjee & $\begin{array}{l}\text { We are not only promoting } \\
\text { peace and non-violence but } \\
\text { we teach these children how } \\
\text { to be compassionate, how to } \\
\text { have empathy for people, as } \\
\text { well as providing tools to } \\
\text { manage their anger and } \\
\text { aggressiveness. }\end{array}$ & $\begin{array}{l}\text { Talking about } \\
\text { society for } \\
\text { prevention of } \\
\text { aggressiveness } \\
\text { and violence } \\
\text { among } \\
\text { adolescents }\end{array}$ & 36 \\
\hline & & $\begin{array}{l}\text { Chris } \\
\text { Hartman, } \\
\text { council } \\
\text { member }\end{array}$ & $\begin{array}{l}\text { They have shared their stories } \\
\text { because of how important } \\
\text { your actions are in shaping } \\
\text { their future, safety and } \\
\text { inclusion in our } \\
\text { compassionate city let's make } \\
\text { sure louisville is a city not } \\
\text { just of fairness but fairness } \\
\text { and compassion for all. }\end{array}$ & $\begin{array}{l}\text { Talking about } \\
\text { immigrants and } \\
\text { violence }\end{array}$ & 39,40 \\
\hline & & $\begin{array}{l}\text { Sarah Nunez, } \\
\text { Council } \\
\text { member of St } \\
\text { Joseph's } \\
\text { neighborhood } \\
\text { association } \\
\end{array}$ & Urgent call for compassion. & $\begin{array}{l}\text { Talking and } \\
\text { supporting } \\
\text { immigration }\end{array}$ & 44 \\
\hline & & $\begin{array}{l}\text { Green, } \\
\text { council } \\
\text { member }\end{array}$ & $\begin{array}{l}\text { I wanted to be a sponsor on } \\
\text { this because as a } \\
\text { compassionate city, how } \\
\text { could we do anything except } \\
\text { to pass something like this. } \\
\text { That is not compassionate }\end{array}$ & $\begin{array}{l}\text { Talking about } \\
\text { violence }\end{array}$ & 81 \\
\hline & & $\begin{array}{l}\text { Hollander, } \\
\text { Council } \\
\text { member }\end{array}$ & $\begin{array}{l}\text { I have heard my colleagues } \\
\text { and other co-sponsors speak } \\
\text { out eloquently about the need } \\
\text { for this and the compassionate } \\
\text { city and I certainly agree with } \\
\text { that }\end{array}$ & $\begin{array}{l}\text { Talking about } \\
\text { violence }\end{array}$ & 88 \\
\hline $\begin{array}{l}9 / 11 / 1 \\
7\end{array}$ & $\begin{array}{l}\text { Louisville Metro } \\
\text { Council Remote } \\
\text { Broadcast } \\
\text { Captioning, Nov } \\
29,2017\end{array}$ & $\begin{array}{l}\text { Connor Allen, } \\
\text { council } \\
\text { member }\end{array}$ & $\begin{array}{l}\text { So I think building affordable } \\
\text { housing and putting more } \\
\text { funds into that is actually } \\
\text { compassionate, and i think } \\
\text { that is the policy that the city } \\
\text { should be looking at, as well } \\
\text { as funding other crisis } \\
\text { management programs. }\end{array}$ & $\begin{array}{l}\text { Talking against } \\
\text { providing funds } \\
\text { for stadium rather } \\
\text { than affordable } \\
\text { housing }\end{array}$ & 7 \\
\hline & & $\begin{array}{l}\text { Nicole } \\
\text { Hardin, } \\
\text { council } \\
\text { member }\end{array}$ & $\begin{array}{l}\text { We talk a lot in louisville } \\
\text { about being a compassionate } \\
\text { city, but literally compassion } \\
\text { means to suffer with. } \\
\text { Compassion and injustice are } \\
\text { alike because they both come } \\
\text { as a } \\
\text { cost. It is a compassion if you } \\
\text { aren't suffering. }\end{array}$ & $\begin{array}{l}\text { Talking about } \\
\text { sexual assault }\end{array}$ & 9,10 \\
\hline
\end{tabular}




\begin{tabular}{|c|c|c|c|c|c|}
\hline $\begin{array}{l}111 / 29 \\
/ 2018\end{array}$ & $\begin{array}{l}\text { Louisville Metro } \\
\text { Council Remote } \\
\text { Broadcast } \\
\text { Captioning, Nov } \\
29,2018\end{array}$ & $\begin{array}{l}\text { Nancy Robert, } \\
\text { council } \\
\text { member }\end{array}$ & $\begin{array}{l}\text { This sends a message of } \\
\text { compassion to the thousands } \\
\text { of medical consumers in our } \\
\text { city and to their family. } \\
\text { Go to louisville.com, brand } \\
\text { our city as compassionate } \\
\text { saying we are touted across } \\
\text { the globe for being } \\
\text { welcoming, inclusive and } \\
\text { compassionate. } \\
\text { We are leaders in kentucky } \\
\text { and in the south for inclusion } \\
\text { and compassion. I am } \\
\text { asking you to continue } \\
\text { leading louisville to become } \\
\text { the most compassionate and } \\
\text { progressive city in the south } \\
\text { by introducing and passing } \\
\text { the LLEP cannabis ordinance. }\end{array}$ & $\begin{array}{l}\text { Talking about } \\
\text { access to medical } \\
\text { condition (passing } \\
\text { of L.L.E.P } \\
\text { Cannabis } \\
\text { ordinance }\end{array}$ & 6,7 \\
\hline \multirow[t]{2}{*}{$\begin{array}{l}13 / 12 / \\
18\end{array}$} & \multirow[t]{2}{*}{$\begin{array}{l}\text { Louisville Metro } \\
\text { Council Remote } \\
\text { Broadcast } \\
\text { Captioning, Dec } \\
\text { 13, } 2018\end{array}$} & $\begin{array}{l}\text { James, } \\
\text { Councilman }\end{array}$ & $\begin{array}{l}\text { Whereas reverend elliott has } \\
\text { brought together many } \\
\text { community and business } \\
\text { leaders and organizations to } \\
\text { assist with Jesus and a Job's } \\
\text { mission, we therefore } \\
\text { proclaim we the louisville } \\
\text { metro council officially } \\
\text { recognize and proclaim } \\
\text { reverend charles elliott and } \\
\text { jesus and a job to be beacons } \\
\text { of light and compassion in the } \\
\text { great city of louisville, } \\
\text { kentucky. }\end{array}$ & $\begin{array}{l}\text { Recognizing the } \\
\text { contribution of } \\
\text { Reverend Elliott, } \\
\text { King Solomon } \\
\text { Baptist }\end{array}$ & 44 \\
\hline & & $\begin{array}{l}\text { President } \\
\text { James }\end{array}$ & $\begin{array}{l}\text { As long as I've known you, } \\
\text { you have had a great heart } \\
\text { and compassion for people } \\
\text { and work so hard and I just } \\
\text { want to say thank you for all } \\
\text { of that }\end{array}$ & $\begin{array}{l}\text { Talking about } \\
\text { Glen who has } \\
\text { served the } \\
\text { commmunity }\end{array}$ & 64 \\
\hline \multirow[t]{2}{*}{$\begin{array}{l}24 / 5 / 1 \\
8\end{array}$} & \multirow[t]{2}{*}{$\begin{array}{l}\text { Louisville Metro } \\
\text { Council Remote } \\
\text { Broadcast } \\
\text { Captioning, May } \\
24,2018\end{array}$} & $\begin{array}{l}\text { President } \\
\text { James }\end{array}$ & $\begin{array}{l}\text { True to his spirit of } \\
\text { compassion and belief in } \\
\text { human rights and in the } \\
\text { immigrant community }\end{array}$ & $\begin{array}{l}\text { Recognized Dr. } \\
\text { Daniels served as } \\
\text { [indiscernible] in } \\
\text { his speech }\end{array}$ & 2,62 \\
\hline & & $\begin{array}{l}\text { Counci } \\
\text { woman, } \\
\text { Sexton Smith }\end{array}$ & $\begin{array}{l}\text { The jefferson county public } \\
\text { school program called the } \\
\text { compassionate schools } \\
\text { project. } \\
\text { Because the number one } \\
\text { premise of the reason to bring } \\
\text { forth the compassionate } \\
\text { school curriculum is based in } \\
\text { nutritional understanding how } \\
\text { to teach them to make } \\
\text { positive choices. }\end{array}$ & $\begin{array}{l}\text { Sharing her work } \\
\text { experience and } \\
\text { the most } \\
\text { important project }\end{array}$ & 62 \\
\hline
\end{tabular}




\begin{tabular}{|c|c|c|c|c|c|}
\hline $\begin{array}{l}29 / 11 / \\
18\end{array}$ & $\begin{array}{l}\text { Urging the mayor } \\
\text { to refraining from } \\
\text { displacing } \\
\text { homeless citizens } \\
\text { in periods of frigid } \\
\text { temperatures }\end{array}$ & $\begin{array}{l}\text { Ackerson, } \\
\text { Councilman }\end{array}$ & $\begin{array}{l}\text { Urging the mayor toward } \\
\text { compassion by refraining } \\
\text { from displacing homeless } \\
\text { citizens in periods of frigid } \\
\text { temperatures that threaten } \\
\text { their health and safety. } \\
\text { Whereas, louisville metro } \\
\text { should do everything in its } \\
\text { power to build trust and } \\
\text { rapport with the homeless in } \\
\text { the hope that compassion will } \\
\text { lead them to seek help }\end{array}$ & $\begin{array}{l}\text { A resolution } \\
\text { pursuant to } \\
\text { louisville metro } \\
\text { code of } \\
\text { ordinances }\end{array}$ & 1,2 \\
\hline \multirow[t]{3}{*}{$\begin{array}{l}25 / 1 / 1 \\
8\end{array}$} & \multirow[t]{3}{*}{$\begin{array}{l}\text { Louisville Metro } \\
\text { Council Remote } \\
\text { Broadcast } \\
\text { Captioning, Jan 5, } \\
2017\end{array}$} & $\begin{array}{l}\text { Patrick } \\
\text { Donegan, } \\
\text { member, } \\
\text { kentucky } \\
\text { colonel }\end{array}$ & $\begin{array}{l}\text { 1. It has great compassion for } \\
\text { the sick. } 2 \text {. On behalf of my } \\
\text { wife and everyone else in this } \\
\text { community, i } \\
\text { urge this council to write a } \\
\text { resolution to frankfurt in } \\
\text { support of hb } 166 \text {, } \\
\text { let us demonstrate or } \\
\text { compassion for those who are } \\
\text { ill by allowing access } \\
\text { to this needed medicine. }\end{array}$ & $\begin{array}{l}\text { Describing his } \\
\text { experience during } \\
\text { his wife's sickness }\end{array}$ & $3-4$ \\
\hline & & $\begin{array}{l}\text { Amanda } \\
\text { Jessie, } \\
\text { government } \\
\text { employee }\end{array}$ & $\begin{array}{l}\text { This leaves some metro's best } \\
\text { employees burnt out with } \\
\text { high compassion fatigue, } \\
\text { every after feeling they have } \\
\text { given up so much in the last } \\
\text { contract to help the city out } \\
\text { during the previous economic } \\
\text { shortfall. Thank you for your } \\
\text { time and dedication to all } \\
\text { louisville metro community } \\
\text { members, in showing the -- } \\
\text { where the community } \\
\text { compassion truly lies. }\end{array}$ & $\begin{array}{l}\text { Talking about } \\
\text { labor rights and } \\
\text { issues and } \\
\text { proposals to the } \\
\text { mayor office }\end{array}$ & 5,6 \\
\hline & & $\begin{array}{l}\text { Bryant } \\
\text { Hamilton, } \\
\text { council } \\
\text { member }\end{array}$ & $\begin{array}{l}\text { Whereas randy coe reflects } \\
\text { the values, morality } \\
\text { compassion and } \\
\text { whereas randy coe has for } 21 \\
\text { years faithfully served as } \\
\text { president of } \\
\text { kosair charities, bringing } \\
\text { community leaders, captains } \\
\text { of industry, and } \\
\text { charitable people from all } \\
\text { across the region together to } \\
\text { help children in } \\
\text { need. }\end{array}$ & $\begin{array}{l}\text { Talking about } \\
\text { Randy Coe,CEO } \\
\text { and } \\
\text { President of } \\
\text { Losair Charities }\end{array}$ & 18 \\
\hline $\begin{array}{l}25 / 6 / 1 \\
9\end{array}$ & $\begin{array}{l}\text { Louisville Metro } \\
\text { Council Remote } \\
\text { Broadcast } \\
\text { Captioning, June } \\
25,2019\end{array}$ & $\begin{array}{l}\text { Chris Finzer, } \\
\text { representative } \\
\text { of Clout }\end{array}$ & $\begin{array}{l}\text { We come to you tonight very } \\
\text { saddened at the crisis of } \\
\text { leadership and the lack of } \\
\text { compassion that led to the } \\
\text { proposed city budget that now } \\
\text { includes zero new dollars for } \\
\text { the } \\
\text { living room program. }\end{array}$ & $\begin{array}{l}\text { Talking about } \\
\text { budget } \\
\text { elimination of } \\
\text { Living }\end{array}$ & 9 \\
\hline
\end{tabular}




\begin{tabular}{|c|c|c|c|c|c|}
\hline & & Mike Kolb & $\begin{array}{l}\text { Even if it was the case, the } \\
\text { compassionate choice would } \\
\text { be to provide enough funding } \\
\text { to keep the program open and } \\
\text { work out these issues later. So } \\
\text { we want to challenge you } \\
\text { tonight to make the right } \\
\text { compassionate choices and to } \\
\text { set the right compassionate } \\
\text { priorities by keeping the } \\
\text { living room living. } \\
\text { Tonight, let's do something } \\
\text { compassionate that we can all } \\
\text { be proud of when we leave } \\
\text { this building. }\end{array}$ & & 13,14 \\
\hline & \multirow[t]{4}{*}{$\begin{array}{l}\text { Louisville Metro } \\
\text { Council Remote } \\
\text { Broadcast } \\
\text { Captioning, Apr 11, } \\
2019\end{array}$} & James Legion & $\begin{array}{l}\text { I'm appealing to the mercy, } \\
\text { grace } \\
\text { and compassion of our } \\
\text { community leaders }\end{array}$ & $\begin{array}{l}\text { Talking about } \\
\text { providing funding } \\
\text { to city parks for } \\
\text { underserved } \\
\text { community }\end{array}$ & 7 \\
\hline & & $\begin{array}{l}\text { Trish Ramey, } \\
\text { council } \\
\text { member }\end{array}$ & $\begin{array}{l}\text { Two week ago, clout held its } \\
\text { annual assembly at memorial } \\
\text { auditoriorum and nearly } 1,100 \\
\text { of us came together to work } \\
\text { to make our city truly } \\
\text { compassionate and effective. } \\
\text { In order to be a truly } \\
\text { compassionate city, a city that } \\
\text { can compete for businesses } \\
\text { and residents, we have to } \\
\text { continue to move forward. }\end{array}$ & $\begin{array}{l}\text { Speaking on } \\
\text { behalf of } \\
\text { clout, citizens of } \\
\text { louisville } \\
\text { organized and } \\
\text { united together }\end{array}$ & 16,17 \\
\hline \multirow[t]{2}{*}{$\begin{array}{l}11 / 4 / 1 \\
9\end{array}$} & & $\begin{array}{l}\text { Charles } \\
\text { Meesiner }\end{array}$ & $\begin{array}{l}\text { During this talk, the mayor } \\
\text { proclaimed the city of } \\
\text { louisville as a compassionate } \\
\text { world class city. } \\
\text { But it is already overcrowded } \\
\text { and inaccessible to many of } \\
\text { the children through the this } \\
\text { compassionate world class } \\
\text { city. So, finally, there will be } \\
\text { one, one public swimming } \\
\text { pool in our compassionate } \\
\text { world class city of over } \\
620,000 \text { people. Is it not } \\
\text { possible for this council to } \\
\text { find } \$ 250,000 \text { needed to } \\
\text { invest in the children of this } \\
\text { compassionate world class } \\
\text { city? }\end{array}$ & $\begin{array}{l}\text { Commenting on } \\
\text { Mayor Greg's } \\
\text { remarks }\end{array}$ & 18,19 \\
\hline & & $\begin{array}{l}\text { Ackerson, } \\
\text { Councilman }\end{array}$ & $\begin{array}{l}\text { They have compassion and } \\
\text { empathy. }\end{array}$ & $\begin{array}{l}\text { Talking about } \\
\text { animal and } \\
\text { vulnerability }\end{array}$ & 39 \\
\hline
\end{tabular}




\begin{tabular}{|c|c|c|c|c|c|}
\hline $\begin{array}{l}25 / 4 / 1 \\
9\end{array}$ & $\begin{array}{l}\text { Louisville Metro } \\
\text { Council Remote } \\
\text { Broadcast } \\
\text { Captioning, Apr 25, } \\
2019\end{array}$ & $\begin{array}{l}\text { Mayor Greg } \\
\text { Fischer }\end{array}$ & $\begin{array}{l}\text { We established a global } \\
\text { reputation as a city of } \\
\text { compassion, turning our give } \\
\text { a day week of service into an } \\
\text { annual festival of volunteeris } \\
\text { good news on that front, in } \\
\text { partnership with metro united } \\
\text { way, we again broke our } \\
\text { world record again this past } \\
\text { week, with } 235,000 \text { acts of } \\
\text { volunteerism and compassion. } \\
\text { Each of our budgets is } \\
\text { embodied in our health, } \\
\text { lifelong learning, and } \\
\text { compassion and is designed to } \\
\text { move us closer. } \\
\text { To make the investments } \\
\text { necessary to sustain a thriving } \\
\text { city that wins in the global } \\
\text { marketplace and whose } \\
\text { reputation for compassion, } \\
\text { innovation, equity, and } \\
\text { opportunity continues to grow } \\
\text { on the world stage, and a city } \\
\text { where every person has the } \\
\text { chance to reach their full } \\
\text { human potential. }\end{array}$ & $\begin{array}{l}\text { During his budget } \\
\text { proposal 2018- } \\
2019 \text { speech }\end{array}$ & $\begin{array}{l}4,5,6, \\
25\end{array}$ \\
\hline \multirow[t]{2}{*}{$9 / 5 / 19$} & \multirow[t]{2}{*}{$\begin{array}{l}\text { Louisville Metro } \\
\text { Council Remote } \\
\text { Broadcast } \\
\text { Captioning, May 9, } \\
2019\end{array}$} & $\begin{array}{l}\text { Shavon } \\
\text { Thompson, } \\
\text { Career } \\
\text { support } \\
\text { specialist, } \\
\text { living room }\end{array}$ & $\begin{array}{l}\text { The living room is unique in } \\
\text { that it is truly a compassionate } \\
\text { place in the city where all are } \\
\text { welcome all of the time, and } \\
\text { the belief that everyone is } \\
\text { capable of recovery and } \\
\text { recovery is real. }\end{array}$ & $\begin{array}{l}\text { Concern about the } \\
\text { proposed budget } \\
\text { elimination for } \\
\text { living and } 2000 \\
\text { plus persons } \\
\text { accessing it }\end{array}$ & 7 \\
\hline & & $\begin{array}{l}\text { Deacon Lucio } \\
\text { Caruso, } \\
\text { representing } \\
\text { Catholic } \\
\text { charities }\end{array}$ & $\begin{array}{l}\text { So please join the LMPD and } \\
\text { other great human service } \\
\text { providers in our } \\
\text { compassionate city to keep } \\
\text { the Living Room living. }\end{array}$ & $\begin{array}{l}\text { Talking in support } \\
\text { og iving }\end{array}$ & 12 \\
\hline $\begin{array}{l}19 / 3 / 2 \\
0\end{array}$ & $\begin{array}{l}\text { Louisville Metro } \\
\text { Council Remote } \\
\text { Broadcast } \\
\text { Captioning, Mar } \\
\text { 19, } 2020\end{array}$ & $\begin{array}{l}\text { President Pro } \\
\text { Tem Markus } \\
\text { Winkler }\end{array}$ & $\begin{array}{l}\text { Every day we see new acts of } \\
\text { compassion and kindness to } \\
\text { help those in need, whether } \\
\text { it's creating a website to } \\
\text { match vulnerable seniors with } \\
\text { healthy individuals, neighbors } \\
\text { helping neighbors by } \\
\text { watching children so a parent } \\
\text { can go to work, people } \\
\text { donating time and money to } \\
\text { organizations trying to meet } \\
\text { the tsunami of needs }\end{array}$ & $\begin{array}{l}\text { Talking about the } \\
\text { support during } \\
\text { coronavirus }\end{array}$ & 2 \\
\hline
\end{tabular}




\section{APPENDIX I - ABOUT CHARTER OF COMPASSION}

The Charter of Compassion is a product of interfaith activism and philanthropism. The interfaith component of the Charter trails back to its founder Karen Armstrong, author of the book 'A History of God'. Karen won the prestigious TedTalk prize in 2008 and used the platform to initiate the Charter of Compassion that seeks to foster global peace by upholding shared ideas of compassion found across different religions. It asserts that compassion is at the heart of all religious traditions and calls to the golden rule of treating others as we would treat ourselves. The Charter highlights the common empathy and compassion found in all religions and emphasizes on the spirituality of helping one another in the society. It calls for an inter-faith approach to understanding religion and in extension promotes religious diversity. The philanthropic component of the Charter comes from large financial support from various private sources and trust funds including renown organizations such as Fetzer Institute and Microsoft (Charter for Compassion, N.D. [b]).

According to the interviewee, who worked for the Charter of Compassion, the following are the key events that shaped the Charter of Compassion:

\begin{tabular}{|l|l|}
\hline Year & Key Events \\
\hline 2008 & $\begin{array}{l}\text { Following the Karen Armstrong TedTalk on Compassion, a high } \\
\text { profile five day event was organized, called Seeds of Compassion, } \\
\text { in Seattle. The event was attended by global celebrities like Dalai } \\
\text { Lama and Desmond Tutu. } \\
\text { The event led to formation of the 501(C)(3) non-profit } \\
\text { organization called the Compassionate Action Network (CAN). }\end{array}$ \\
\hline
\end{tabular}




\begin{tabular}{|c|c|}
\hline & $\begin{array}{l}\text { The CAN grew out of an interest by key players in the event, } \\
\text { which included wealthy philanthropists, to continue to continue } \\
\text { the mission of promoting the values of compassion. }\end{array}$ \\
\hline 2009 & $\begin{array}{l}\text { In February 2009, a group called "Council of Conscience" (also } \\
\text { called "Council of Sages" and currently "Global Compassion } \\
\text { Council" - group consisting of philanthropists from the five major } \\
\text { religions), Karen Armstrong, and CAN met at Switzerland to } \\
\text { define the work the Charter of Compassion. The Charter was } \\
\text { merged with CAN (TEDBlog 2009). }\end{array}$ \\
\hline 2010 & $\begin{array}{l}\text { The Charter of Compassion launched its International } \\
\text { Compassionate City program, funded by US } \$ 200,000 \text { grant from } \\
\text { Fetzer Institute. } \\
\text { Seattle was the first city to sign the Charter. } \\
\text { The initial requirement of the to be signatory of the Charter was } \\
\text { following: } \\
\text { 1) City governance (Mayor and City Council) affirm the "Charter } \\
\text { for Compassion". } \\
\text { 2) Develop a comprehensive action plan to address the suffering of } \\
\text { the city within } 10 \text { months. }\end{array}$ \\
\hline 2011 & $\begin{array}{l}\text { In March 2011, the city of Basalt, Colorado, became the second } \\
\text { city to affirm to the Charter to become Compassionate City. } \\
\text { In November 2011, Louisville affirmed to the Charter to become } \\
\text { the third city. }\end{array}$ \\
\hline 2012 & $\begin{array}{l}\text { The Charter of Compassion abandons the second requirement } \\
\text { (action place for compassionate initiatives) citing it to be too } \\
\text { constraining. The only requirement, thus, to be a Compassionate } \\
\text { City is to affirm to the Charter of Compassion. }\end{array}$ \\
\hline 2013 & $\begin{array}{l}\text { In the 81st Annual U.S. Conference of Mayors,2013, a resolution } \\
\text { titled "Compassion as an Effective Public Policy" was signed that } \\
\text { encouraged cities across US to adopt the Charter of Compassion. }\end{array}$ \\
\hline
\end{tabular}

The Charter of Compassion promotes the idea of compassion- a calling to the principle of attending the suffering of others. It claims that this principle of Compassion is the ancient core of humanity and can be subscribed universally regardless of individual difference in belief systems. The charter claims that the principle of Compassion is a fundamental that our current global society must ascribe to, both publicly and privately to form an utopian global community that minimizes suffering. More importantly, it ascribes this principle as highest form of human 
morality, popularizing the ideal of Compassion as scared: "It is the path to enlightenment, and indispensable to the creation of a just economy and a peaceful global community" (Charter of Compassion n.d.).

The Charter of Compassion popularized the principle Compassion on the ground that it is an interfaith approach which brings solidarity, it is essential bridge for common peace, and that it is a moral responsibility of every individuals. Since its inception, the Charter has received international attention from various quarters. Advocates and signatories of the Charter include host of global celebrities such as Dalai Lama, the Archbishop Desmond Tutu, the Queen of Jordan Noor Al-Hussein, Noble laureate Jody Williams, Noble laureate Marti Ahtisari, late boxing legend Mohammad Ali and several billionaire entrepreneurs like Richard Branson (Virgin Group) and Pierre Morad Omidyar (eBay). Such celebrity endorsements increased the reputation of the Charter and boosted the popularity of the idea of compassion in certain quarters of the society. So did the program of Compassionate City: since its inception more than 90 cities across the world have affirmed to the Charter and calls themselves to be compassionate in some capacity, 50 of which have been in the United States alone (Charter for Compassion, N.D. [a]). 


\section{CURRICULUM VITA}

NAME:

ADDRESS:

\section{Education}

- Ph.D. in Urban and Public Affairs Doctoral Candidate University of Louisville, USA

- Master in Business Administration Institute of Business Administration, Dhaka University Bangladesh

- Master in Resource and Environmental Management North South University, Bangladesh Thesis: Environmental and Social Risk Management in Banking Sector of Bangladesh

- Bachelor of Business Administration North South University, Bangladesh

\section{Conference:}

- Paper Presented: Critical Discourse Analysis as a Method to Study City Branding as a Tool of Governmentality Conference: Annual Conference of the International Place Branding Association, November 2019, Volos, Greece

- Poster Presented: Why Bangladesh is becoming a major market for sustainable energy Conference: Advanced Energy Conference, April 2013, New York, USA

- Paper Presented: Assessing the Environmental Risk Management practices in the Banking sector of Bangladesh Conference: International Conference on Climate Change and Water Security. December 2015, Dhaka, Bangladesh

\section{Colloquium:}

- Topic: Using Machine Learning as a methodology in Policy Research BRAC Institute of Governance and Development, BRAC University, Fall 2019

- Topic: Circular E-Waste, Capitalism and Site-Multiple Skills 
Quantitative Skills: Agent Based Modelling, Structural Equation Modelling, Econometrics, Bibliometric, GIS, Data Science

Qualitative Skills: Critical Discourse Analysis, Content Analysis, Case Study

\section{Teaching Experience}

1. Organization: University of Louisville

Designation: Instructor, Department of Political Science

Duration: January 2020 to April 2020

Work Responsibilities:

- Teach Undergraduate Urban Political Economy

2. Organization: University of Liberal Arts Bangladesh

Designation: Adjunct Faculty, School of Business

Duration: $\quad$ May 2017 to August 2017

Work Responsibilities:

- Teach Undergraduate Finance class.

\section{Professional Experience}

1. Organization: Nathan Associates London Ltd. (Business Finance for Poor- Bangladesh) Designation: M\&E Coordinator and Financial analyst

Duration: $\quad$ November 2014 to August 2016.

Work Responsibilities:

- Lead the Monitoring \& Evaluation component of the program.

2. Organization: International Finance Corporation

Designation: Consultant, Access to Finance

Duration: $\quad$ November 2011 to December 2013.

Work Responsibilities:

- Assist in design, implementation and monitor projects under the Environmental Risk Management, Affordable Housing Finance and Sustainable Energy Finance programs.

\section{Awards and Honors}

- Training in prestigious Arizona State University of Winter School

"Agent-Based Modeling of Social-Ecological Systems

- Graduate Fellowship received from the School of Interdisciplinary and Graduate Studies of University of Louisville

- Merit Scholarship received from Canadian International Development Agency (Building Environment Governance Capacity Project) to pursue Master program in North South University

- Fellowship received Prince's Trust Initiative (PTI UK) to participation in Mosaic International Leadership Programme in Jordan

- Winner of global World Bank-IFC competition - "Capturing your story". 